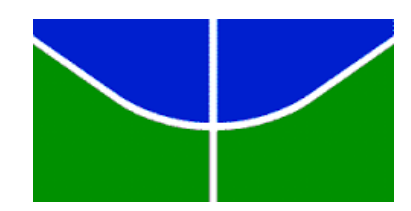

Universidade de Brasília - UnB

Instituto de Psicologia - IP

Programa de Pós-Graduação em Psicologia Clínica e Cultura - PPG PsiCC

Trajetórias Marcadas:

Histórias de vida de adolescentes com vivência de acolhimento institucional

Juliana Castro Benício de Carvalho

Brasília - DF 


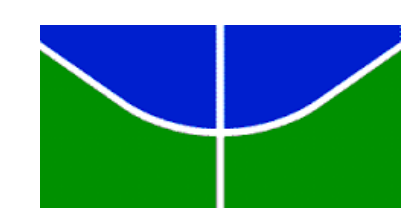

Universidade de Brasília - UnB

Instituto de Psicologia - IP

Programa de Pós-Graduação em Psicologia Clínica e Cultura - PPG PsiCC

\title{
Trajetórias Marcadas:
}

Histórias de vida de adolescentes com vivência de acolhimento institucional

\author{
Juliana Castro Benício de Carvalho
}

Tese de Doutorado apresentada ao Programa de Pós-Graduação em Psicologia Clínica e Cultura - PPG PsiCC do Instituto de Psicologia da Universidade de Brasília IP/UnB, como parte dos requisitos necessários à obtenção do título de Doutor em Psicologia.

Orientadora: Prof ${ }^{\mathrm{a}}$. Dra. Liana Fortunato Costa

Brasília - DF 


\title{
Universidade de Brasília - UnB \\ Instituto de Psicologia - IP \\ Programa de Pós-Graduação em Psicologia Clínica e Cultura - PPG PsiCC
}

Essa tese foi aprovada pela seguinte Banca Examinadora:

Prof $^{\mathrm{a} .}$ Dr $^{\mathrm{a}}$ Liana Fortunato Costa
Presidente

Prof. Dr. Jacques Rhéaume

Membro Externo

Departamento de Comunicação Pública e Social - Université du Québec à Montréal

\author{
Prof $^{\mathrm{a}}$. Dr ${ }^{\mathrm{a}}$. Teresa Cristina O. Carreteiro \\ Membro Externo \\ Departamento de Psicologia - Universidade Federal Fluminense
}
Dr $^{\mathrm{a}}$. Olga Maria Pimentel Jacobina de Souza Membro Externo

Subsecretária de Assistência Social - Secretaria de Desenvolvimento Humano e Social

\begin{tabular}{c}
\hline Prof $^{\mathrm{a}} . \mathrm{Dr}^{\mathrm{a}}$. Maria Inês Gandolfo Conceição \\
Membro Interno \\
Instituto de Psicologia - Universidade de Brasília
\end{tabular}

de Psicologia - Universidade de Brasília

Prof $^{\mathrm{a}}$. Dr ${ }^{\mathrm{a}}$. Maria Aparecida Penso

Membro Suplente

Programa de Mestrado e Doutorado em Psicologia - Universidade Católica de Brasília 
Deve-se seguir pessoas que buscam a verdade, mas sempre fugir daquelas que afirmam tê-la encontrado.

André Gide 
Aos adolescentes e aos profissionais do Serviço de Acolhimento Institucional, que esse trabalho possa contribuir para a criação de formas de convivência mais cuidadosas e respeitosas. 


\section{AGRADECIMENTOS}

Ao longo dessa pesquisa, só tenho a agradecer por ter chegado onde eu cheguei, por ter aprendido muito e por ter crescido enquanto pesquisadora, profissional e, principalmente, enquanto pessoa.

Primeiramente, agradeço à Deus por me ajudar para que tudo desse certo e se organizasse a meu favor.

Agradeço à $\operatorname{Prof}^{\mathrm{a}} \operatorname{Dr}^{\mathrm{a}}$ Liana Fortunato Costa pela orientação, dedicação e paciência durante meus estudos. Seus ensinamentos foram essenciais em minha trajetória.

Ao Prof. Dr. Jacques Rhéaume por ter me orientado em meu estágio doutoral na Université du Québec à Montréal - UQAM, Canadá, com muita sabedoria e dedicação.

Aos participantes dessa pesquisa, pela disponibilidade de compartilhar comigo suas histórias de vida.

Aos membros da banca de defesa pela parceria e por terem aceitado ler esse trabalho e contribuir para seu enriquecimento: Prof. Dr. Jacques Rhéaume, $\operatorname{Prof}^{\mathrm{a}} \operatorname{Dr}^{\mathrm{a}}$ Teresa Carreteiro, $\operatorname{Dr}^{\mathrm{a}}$ Olga Jacobina, $\operatorname{Prof}^{\mathrm{a}} \operatorname{Dr}^{\mathrm{a}}$ Inês Gandolfo e Prof ${ }^{\mathrm{a}} \operatorname{Dr}^{\mathrm{a}}$ Maria Aparecida Penso.

À Secretaria de Desenvolvimento Humano e Social, pela autorização de afastamento para estudos por um ano, o que permitiu que eu realizasse parte da minha pesquisa em Montreal. Aos colegas de trabalho pelo companheiristo e trocas de experiências.

À Coordenação de Aperfeiçoamento de Pessoal de Nível Superior - CAPES, pela bolsa de estudos que permitiu meu estágio doutoral em Montreal/ Canadá.

À Prof ${ }^{a} \operatorname{Dr}^{\mathrm{a}}$ Teresa Carreteiro por ter me apresentado o Prof. Dr. Jacques Rhéaume e à Prof ${ }^{a} \operatorname{Dr}^{a}$ Vera Roesler, por ter me ajudado em meu primeiro contato com ele.

À Lise Renaud, Lynne O'Breham e Élise Ducharme, por terem me acolhido e me apoiado no tempo em que estudei na UQAM.

Aos professores Dr. Michel Parazelli e Chantal Aurousseau, por terem me aceitado em suas disciplinas na UQAM, com momentos de muitas trocas e aprendizado.

Aos amigos que conheci em Montreal: Thaís e Camila da HiBonjour, professores de francês Jesus, Justine e Bertha e alunos da BLI.

Ao meu marido Edson Benício pela cumplicidade e pela força e minha filha Giovana, pela paciência que teve ao longo desses quatro anos, os quais não pude estar com ela com a dedicação que ela merece.

Aos meus pais, irmãos e demais familiares pelo apoio e por entenderemm minha ausência em vários encontros de família.

À Beth, minha psicoterapeuta que já me acompanha há muitos anos e que esteve comigo nessa jornada, me guiando nesse processo que também foi de muito crescimento pessoal.

À Maria del Carmen e Tatiana Yokoy, amigas especiais, pela força na reta final de preparação desse trabalho.

À Ludmila Guimarães, por sua amizade que se iniciou durante o Doutorado, pelo apoio, pelas trocas e aprendizados que, com certeza, irão render muitos frutos.

Aos demais amigos, colegas e professores que me acompanharam.

$\mathrm{E}$ às pessoas que conheci nesse caminho, pelos encontros e pelos aprendizados: Vincent de Gaulejac, Isabelle Fortier, Diane Laroche, Céline Yelle, Patricia Guerrero, Pascal Ganvani, Ana Carolina, Valéria Quiroga, Fernando Gastal e Sérgio Barroca. 


\section{SUMÁRIO}

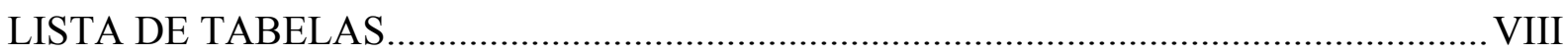

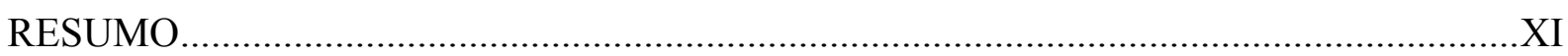

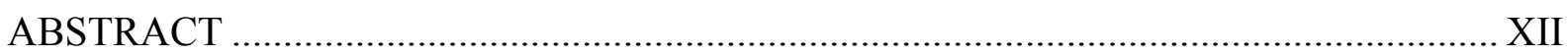

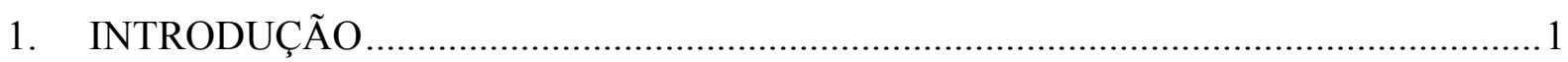

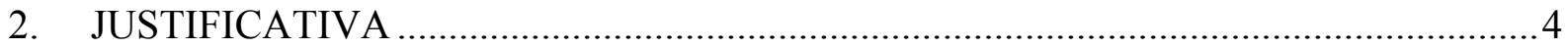

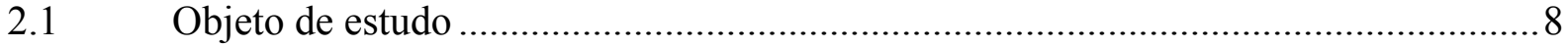

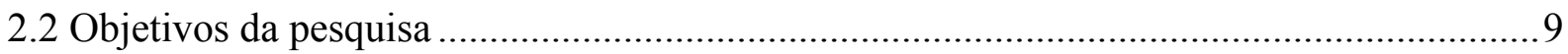

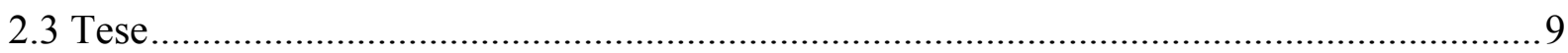

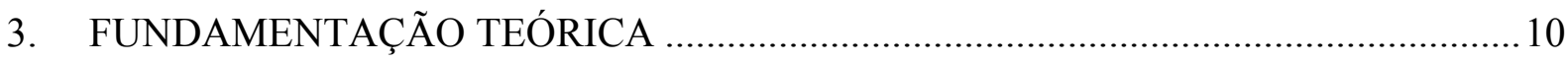

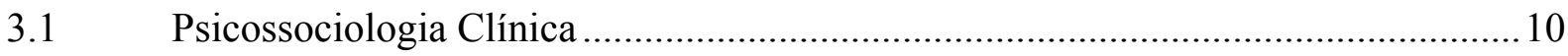

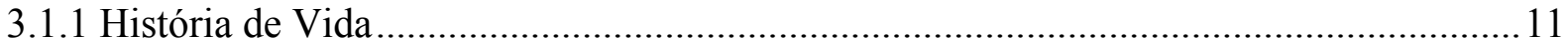

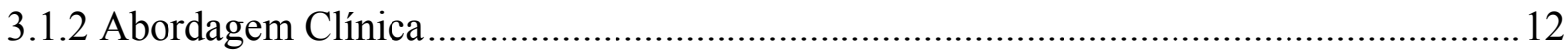

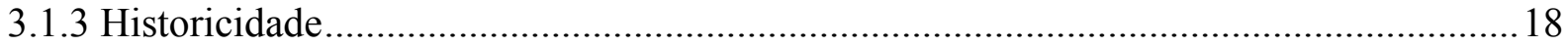

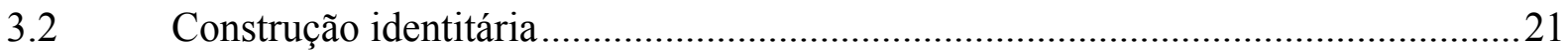

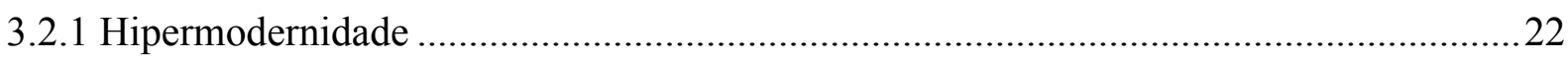

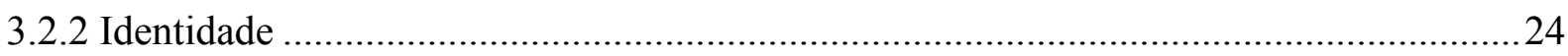

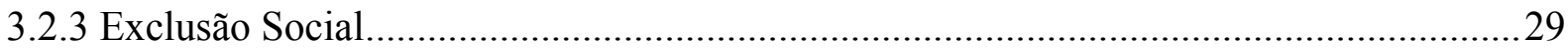

3.3 Medida Protetiva de Acolhimento Institucional ................................................. 40

3.3.1 Serviço de acolhimento de crianças e adolescentes..............................................41

3.3.2 A adolescência em acolhimento institucional ............................................................... 44

3.3.3 História do acolhimento institucional e repercussões para o adolescente .............48

3.3.4 Adolescentes em acolhimento institucional e em situação de rua...................................51

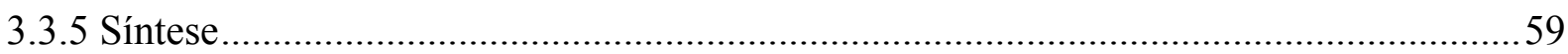

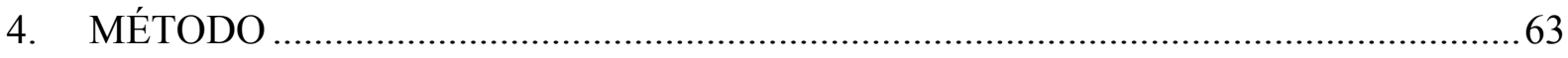

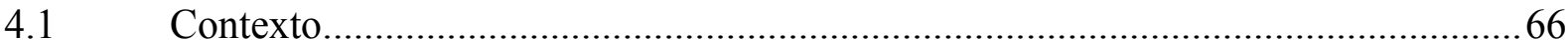

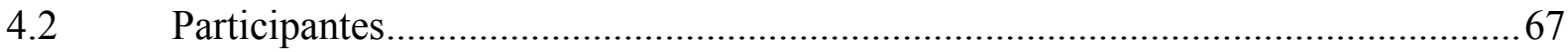

4.3 Acesso às trajetórias de vida: delimitação conceitual e procedimento de pesquisa.68

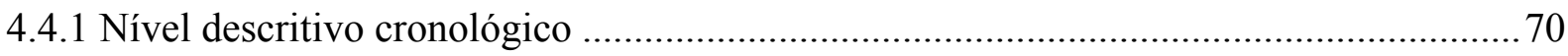

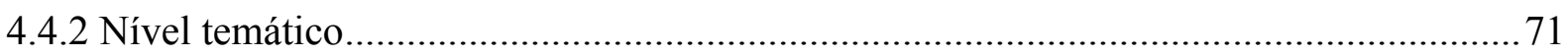

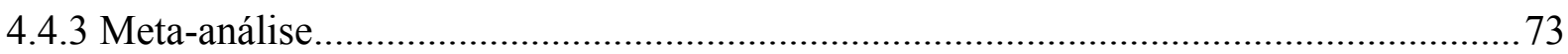

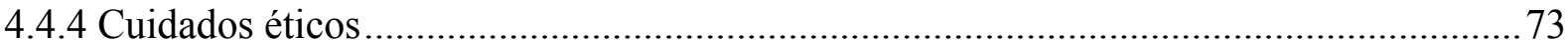

5. ESTUDO 1 - MARCOS : A TRAJETÓRIA DE VIDA QUE SE CONFUNDE COM A HISTÓRIA DO ACOLHIMENTO INSTITUCIONAL ......................................................... 75 


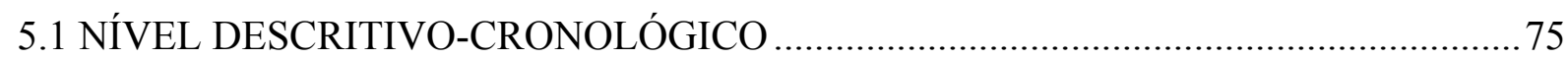

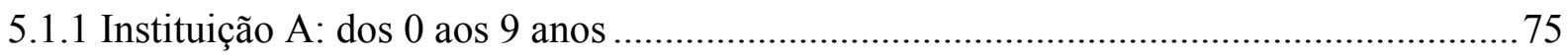

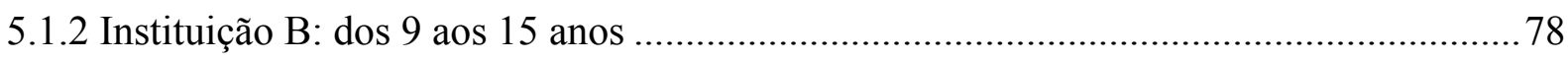

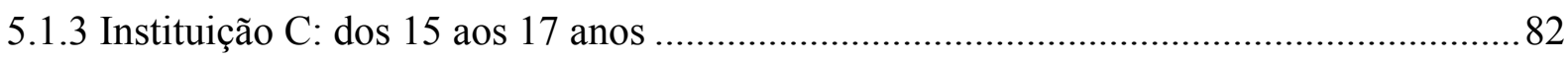

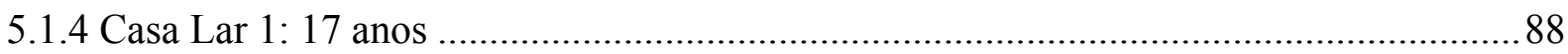

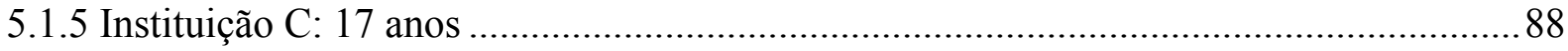

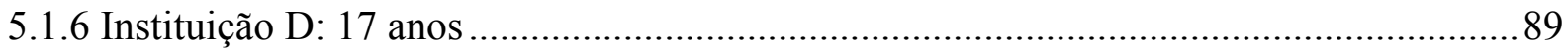

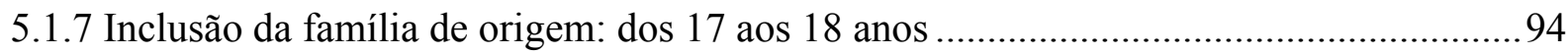

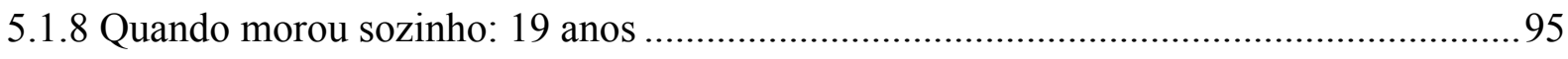

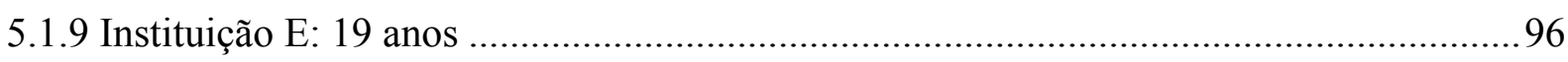

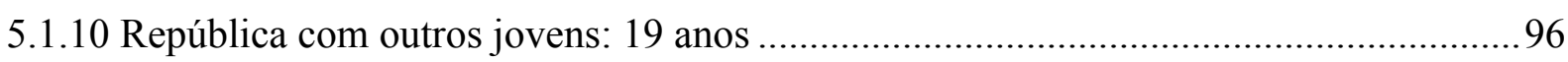

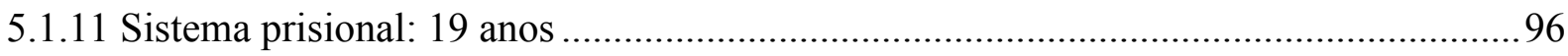

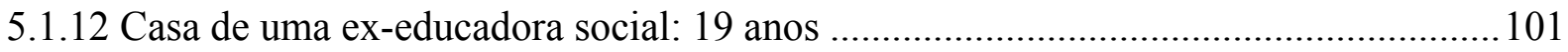

5.1.13 Reflexões gerais feitas por Marcos ao longo das entrevistas ..................................... 107

5.2 NÍVEL TEMÁTICO 1: ESTRATÉGIAS DE RESPOSTAS EM PROCESSO DE

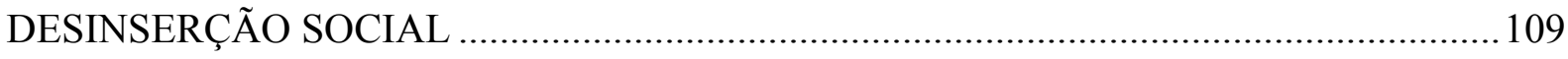

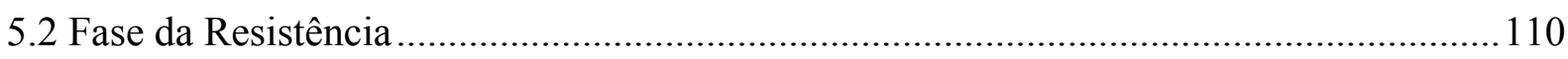

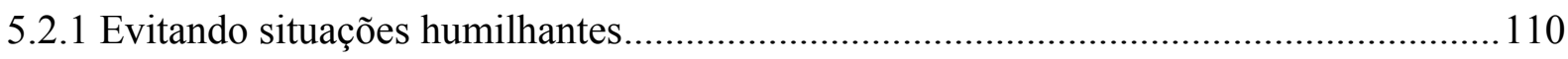

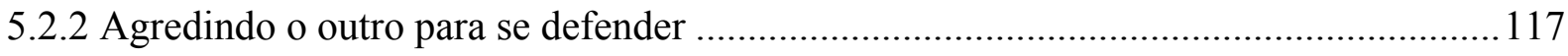

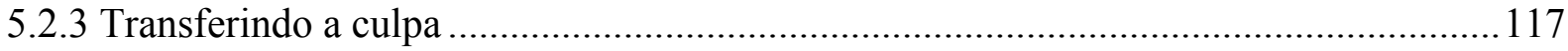

5.2.4 Buscando reconhecimento por meio de relações familiares........................................... 119

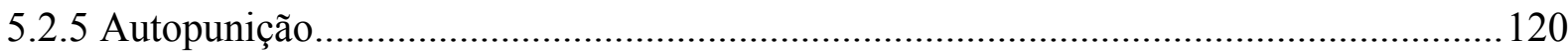

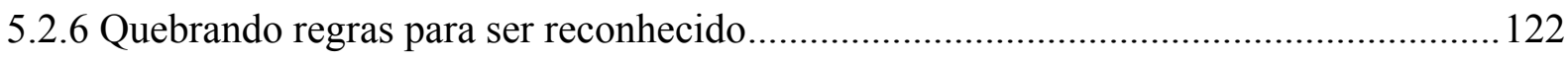

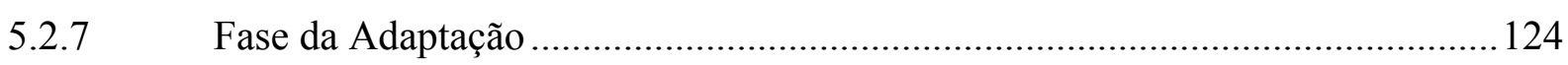

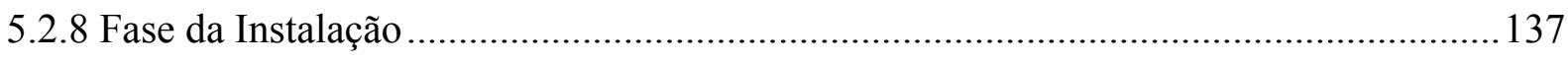

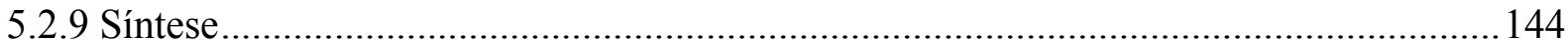

5.3 NÍVEL TEMÁTICO 2: REPRESENTAÇÃO IMAGINÁRIA A PARTIR DOS

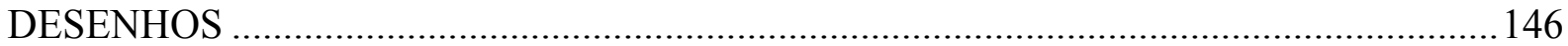

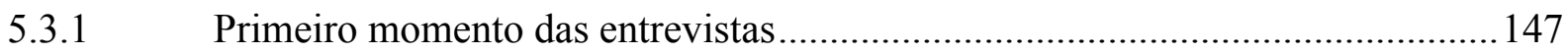

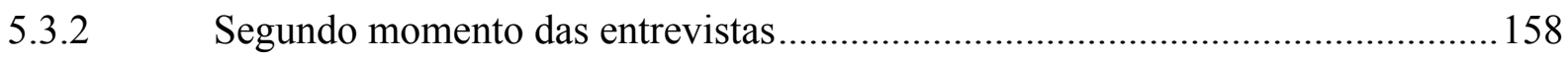

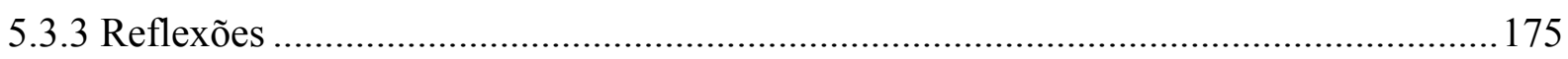

6. ESTUDO 2 - SIMONE : A BUSCA DE PERTENCIMENTO …................................. 177

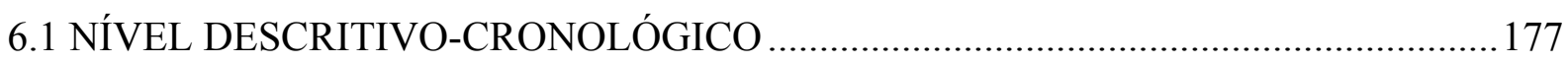

6.1.1 Infância - antes do acolhimento institucional ............................................................ 178 
6.1.2 Adolescência - Acolhimento Institucional .................................................... 182

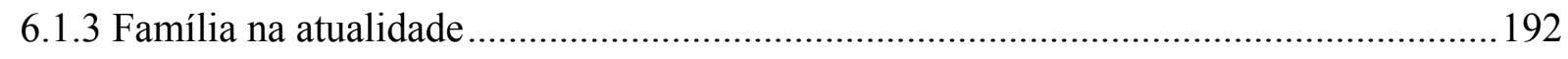

6.2 NÍVEL TEMÁTICO 1: TENSÃO ENTRE A INSTITUIÇÃO DE ACOLHIMENTO E A

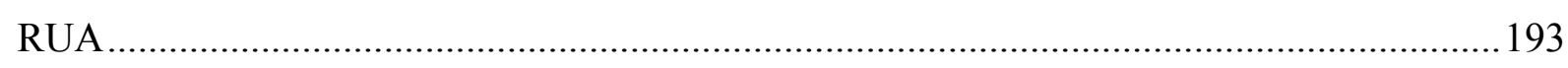

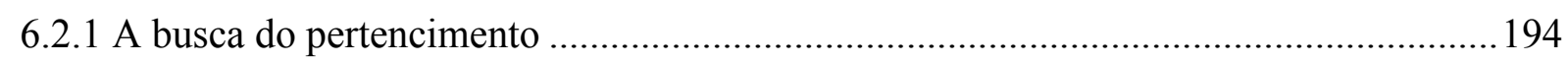

6.2.2 Drogas e diversão: a busca do reconhecimento e do pertencimento coletivo ................ 196

6.2.3 Casa Lar: a ilusão de proximidade entre acolhido e profissional ................................ 199

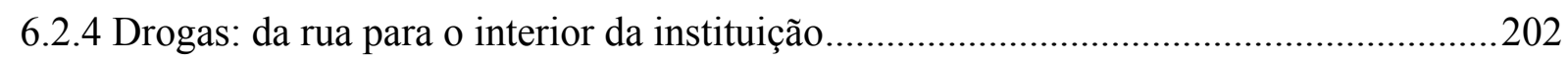

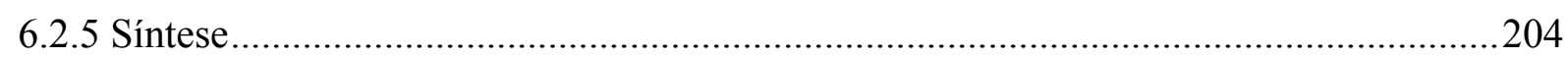

6.3 NÍVEL TEMÁTICO 2: REPRESENTAÇÃO IMAGINÁRIA A PARTIR DOS

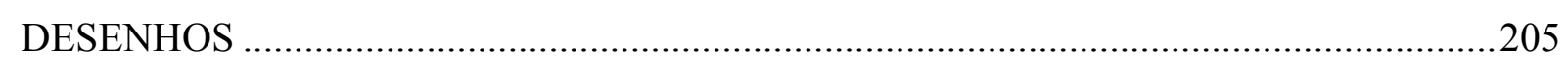

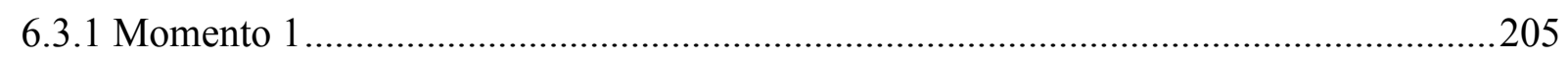

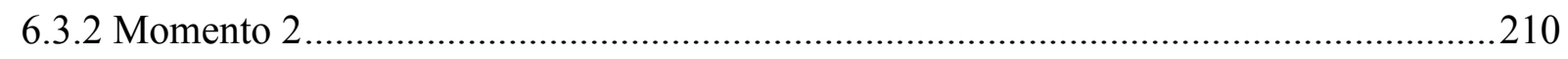

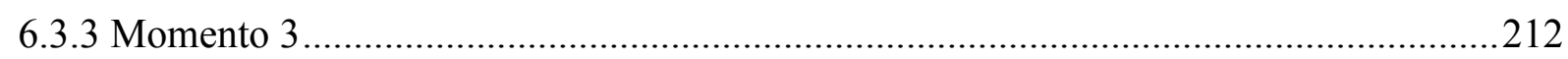

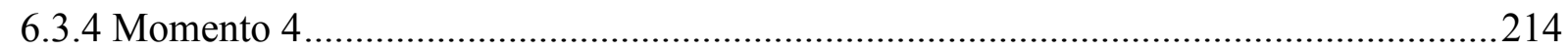

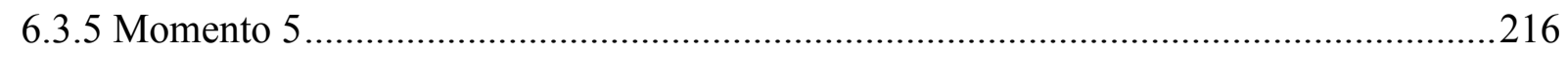

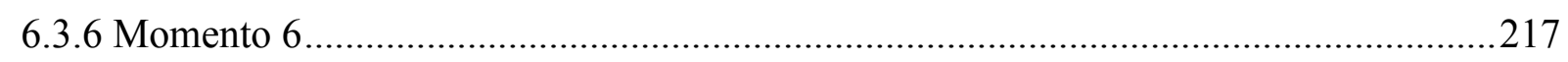

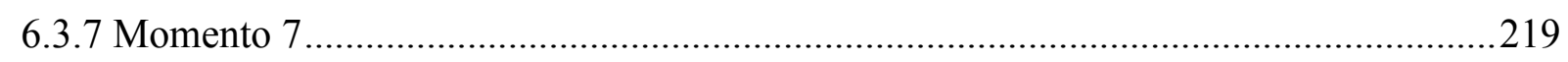

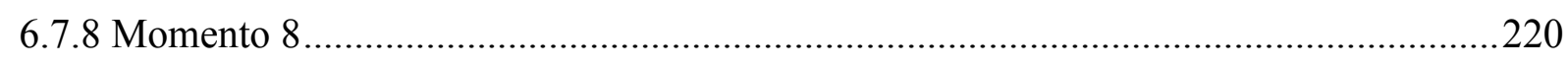

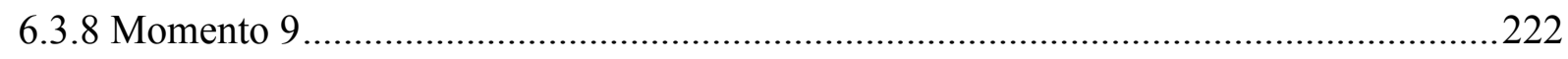

7. SABER PROFISSIONAL - ALICE: RESSONÂNCIAS DAS HISTÓRIAS DE VIDA

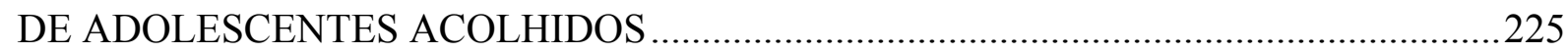

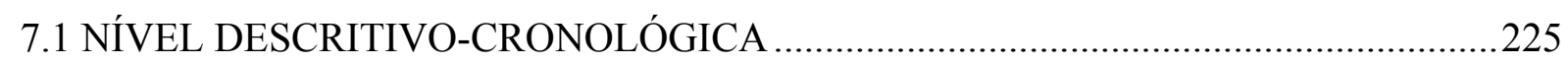

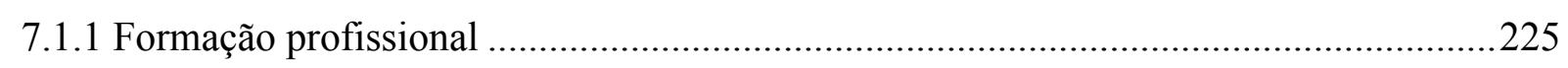

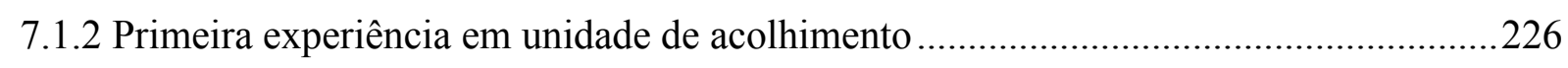

7.1.3 Trabalho com adolescentes autores de ato infracional em instituição privada..............229

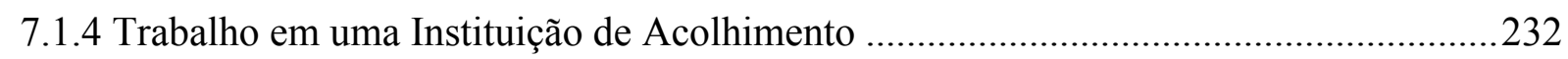

7.1.5 Reestruturação e projeto político pedagógico …….....................................................235

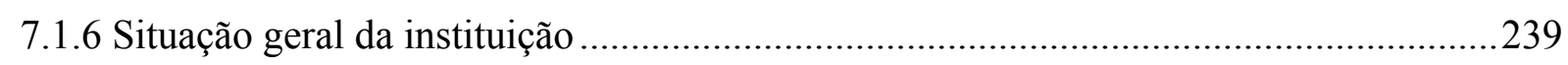

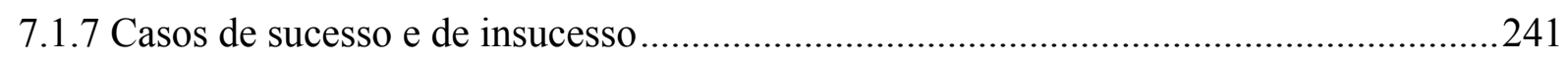

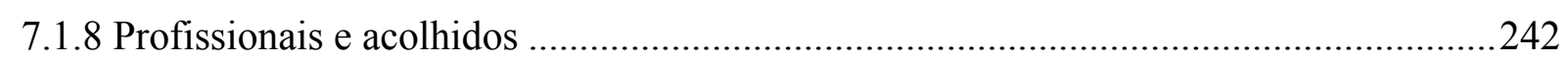

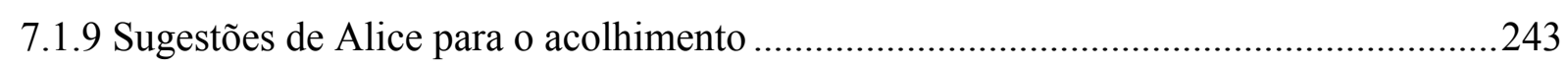

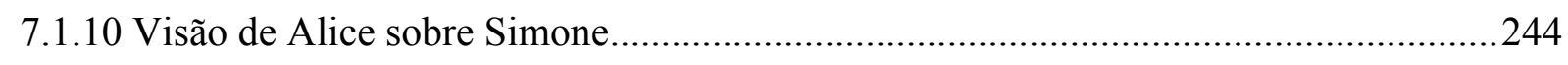

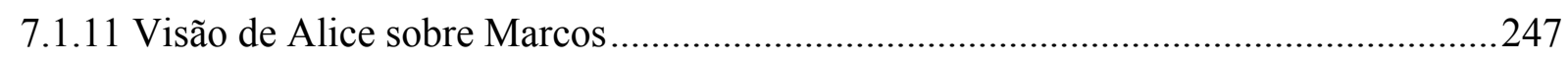


7.1.12 Movimento instituição de acolhimento/ rua e vice-versa 248

7.1.13 Considerações 249

\subsection{NÍVEL TEMÁTICO: ASPECTOS ORGANIZACIONAIS SOBRE O ACOLHIMENTO}

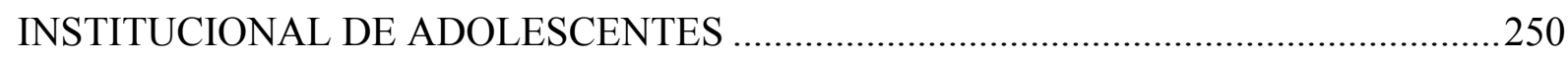

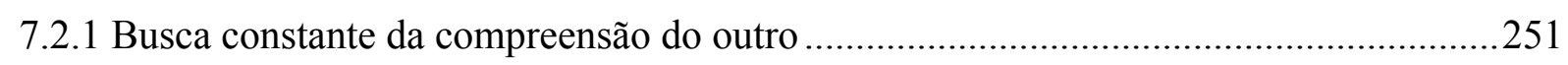

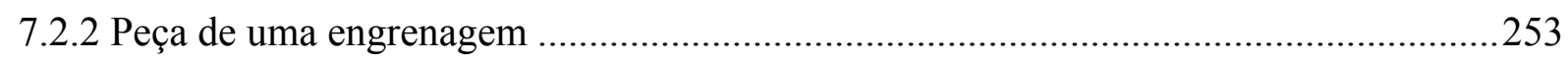

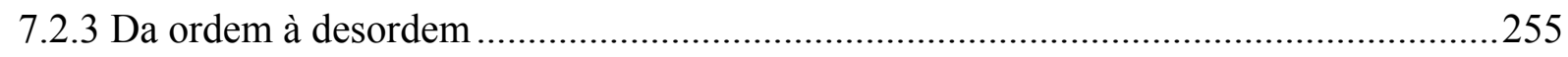

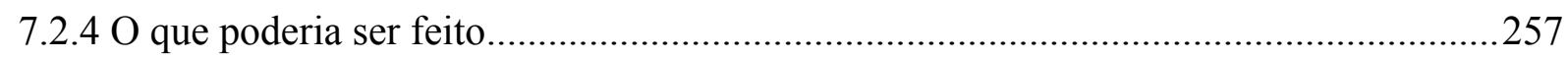

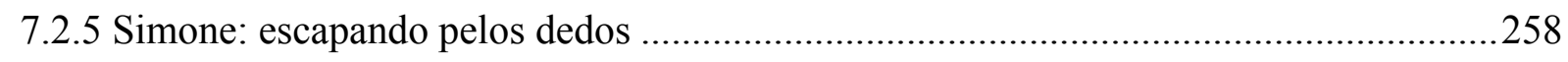

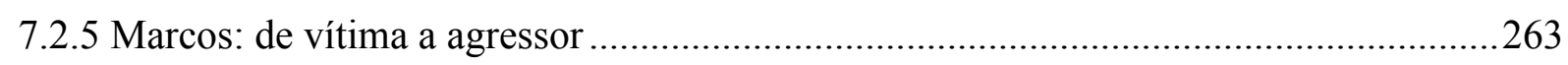

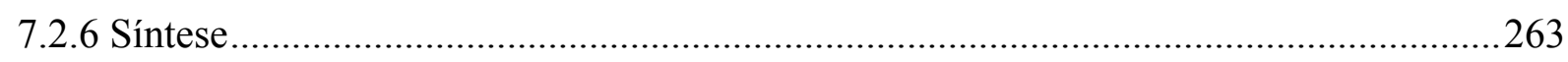

8. RELAÇÃO DA PESQUISADORA COM SUA PESQUISA: PROCESSO DE

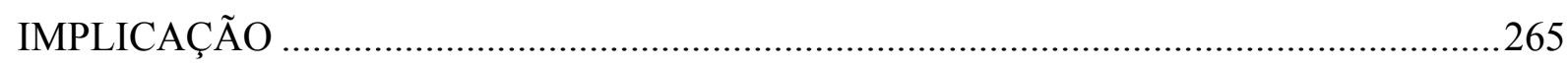

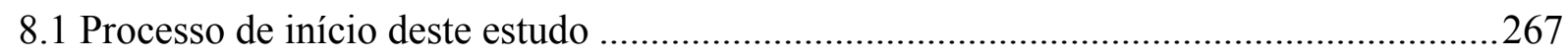

8.2 Alguns elementos de minha história pessoal e profissional ............................................268

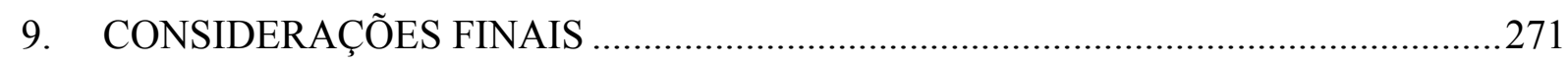

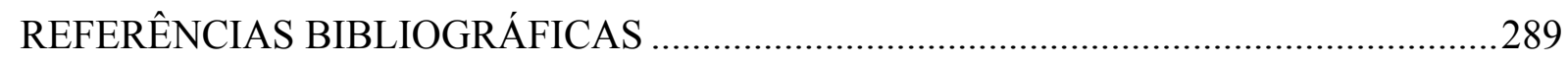

Apêndice A - Termo de Consentimento Livre e Esclarecido ..................................................302

Apêndice B - Parecer Consubstanciado de Projeto de Pesquisa.............................................304

Apêndice C - Roteiro de entrevista sobre trajetória profissional .........................................306 
LISTA DE TABELAS

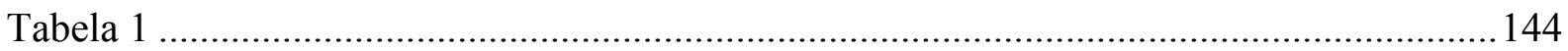

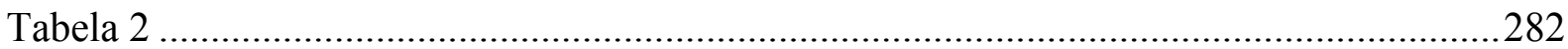

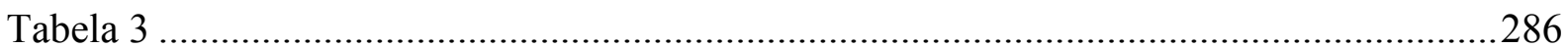




\section{LISTA DE FIGURAS}

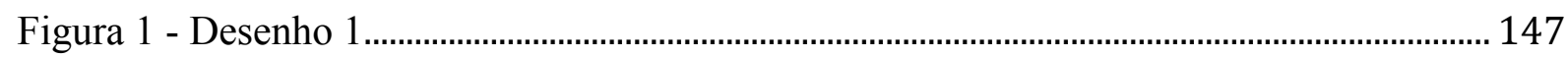

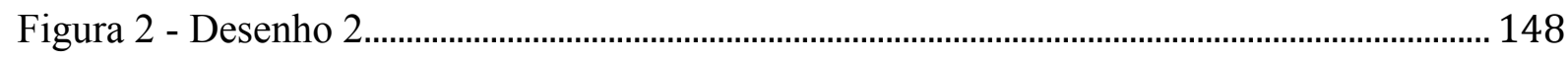

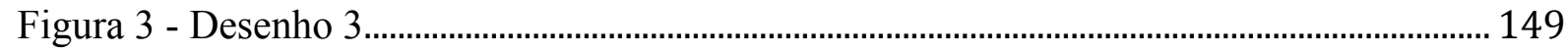

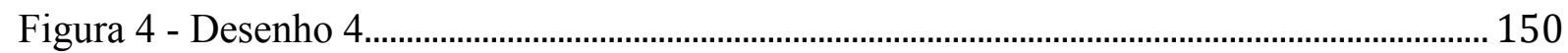

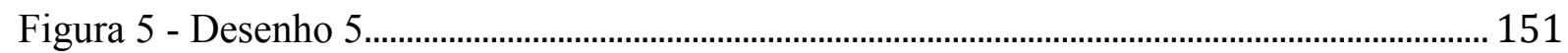

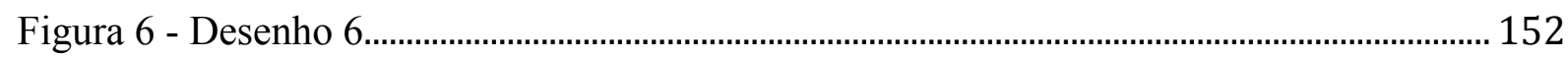

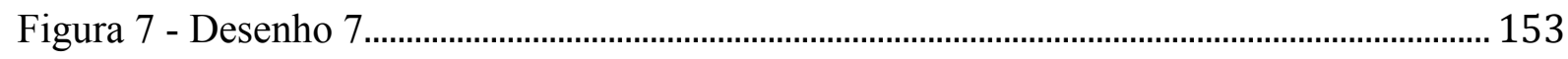

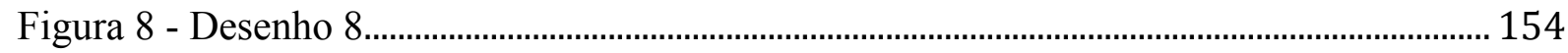

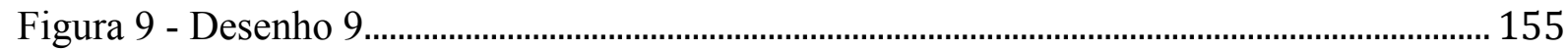

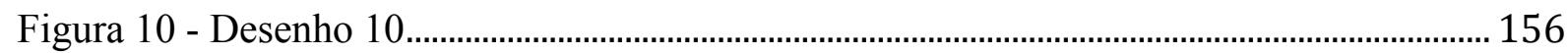

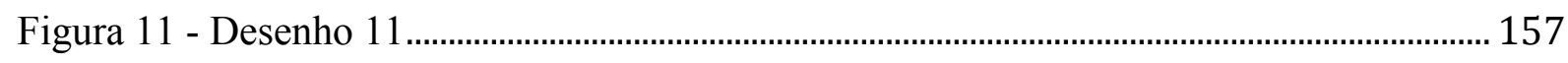

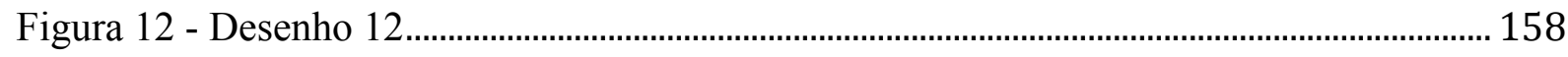

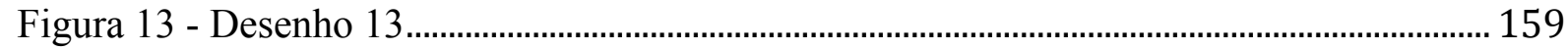

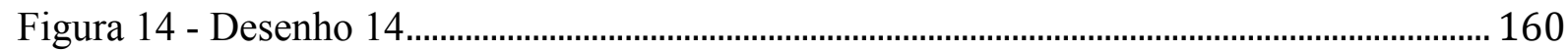

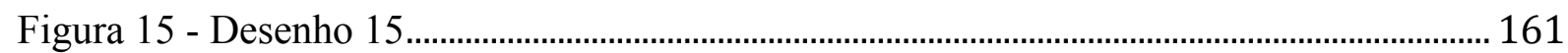

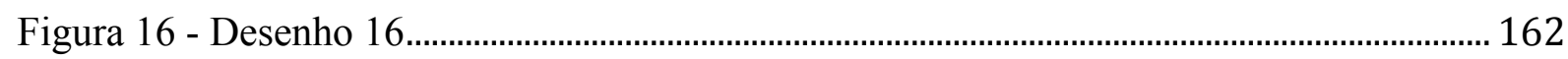

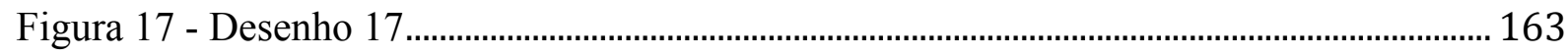

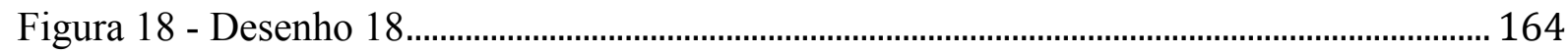

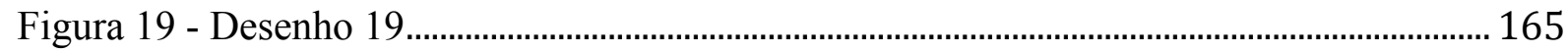

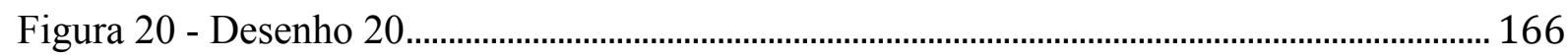

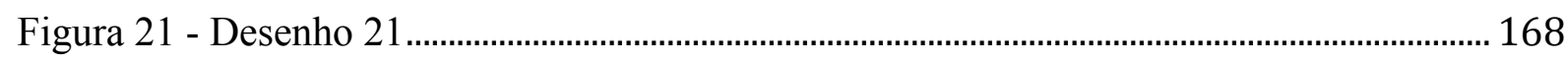

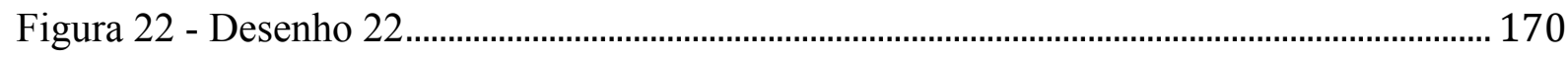

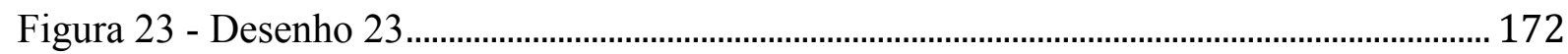

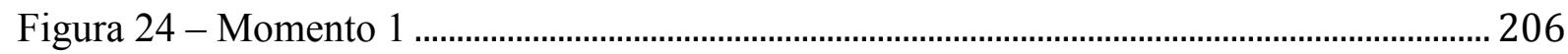

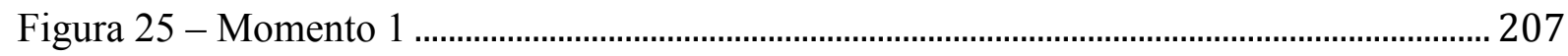

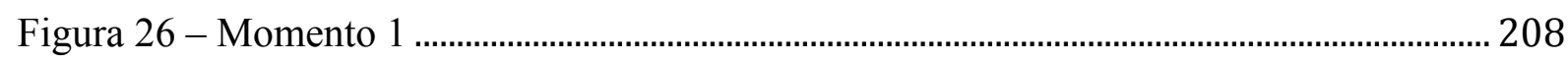

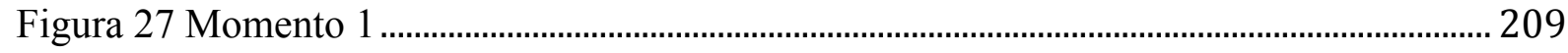

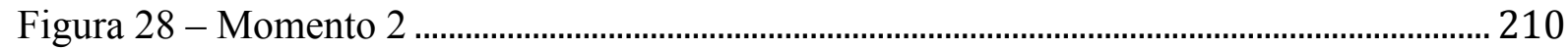

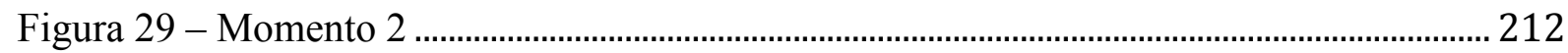

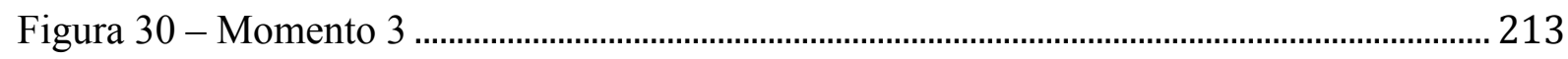

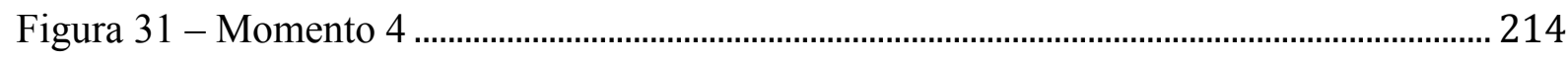

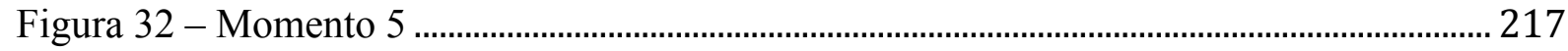


Figura 33 - Momento 6 218

Figura 34 - Momento 7 219

Figura 35 - Momento 8 220

Figura 36 - Momento 9 223 


\section{RESUMO}

Carvalho, J. C. B. de (2015). Trajetórias Marcadas: histórias de vida de adolescentes com vivência de acolhimento institucional. Tese de Doutorado. Universidade de Brasília, Brasília

O presente texto trata de uma pesquisa qualitativa sobre histórias de vida de adolescentes em situação de acolhimento institucional, que se desenvolveu no intuito de compreender a dinâmica de adolescentes que encontram-se acolhidos e que com frequência evadem da instituição e ficam morando na rua, retornando para o acolhimento tempos depois. A tese defendida possui duas dimensões, sendo que a primeira diz respeito à dimensão metodológica, na qual um objeto mediador da expressão da história de vida de adolescentes, atua como facilitador da narrativa e a segunda, tem-se que a expressão da história de vida favorece a ressignificação dessa história para o próprio sujeito, sendo, portanto, não somente um método de pesquisa mas uma alternativa de intervenção profissional. $O$ referencial teórico que subsidiou esse trabalho foi o da Psicossociologia Clínica, realizado por meio da metodologia de Histórias de Vida, que tem como base a abordagem clínica e que busca compreender um fenômeno social por meio do acesso à subjetividade de indivíduos que compõem a situação investigada. Participaram do estudo dois adolescentes, um menino e uma menina, que estavam acolhidos em uma instituição à época da pesquisa, além de uma assistente social que trabalhava em uma unidade de acolhimento. Os adolescentes narraram suas histórias de vida, ao longo de vários encontros, ao mesmo tempo em que desenhavam livremente, o que facilitou a expressão dessas histórias. Em relação à assistente social, ela falou de sua trajetória profissional, em um único encontro, sem a necessidade de qualquer elemento concreto que mediasse sua fala. A análise dessas histórias se deu em dois níveis: nível descritivocronológico, que organizou as histórias em ordem cronológica, subdividindo-as em temas, a partir dos assuntos mais recorrentes encontrados e nível temático, sendo os temas: estratégias de respostas em processo de desinserção social; tensão entre a instituição de acolhimento e a rua e, por fim, aspectos organizacionais sobre o acolhimento institucional de adolescentes. Essa análise mostrou que os adolescentes podem fazer uso de estratégias individualizadas para lidarem com a situação de estar em uma instituição de acolhimento, e, num segundo momento, passam a fazer uso de estratégias coletivas, grupais, para evitar o pertencimento a um grupo que é visto pela sociedade, como sendo formado por crianças e adolescentes vindos de uma família que falhou em suas funções de cuidado e proteção. Assim, é importante que os profissionais que trabalhem em uma instituição de acolhimento tenham uma postura clínica no atendimento e acompanhamento dos adolescentes acolhidos, para que acessem percepções e sentimentos, criando, junto ao adolescente, alternativas frente ao vivido. Nesse sentido, essa pesquisa propõe alguns modos de intervenção que favorecem a escuta clínica dos profissionais do acolhimento: trabalho em grupo com adolescentes; uso do desenho para facilitar a expressão de histórias de vida; ingresso dos adolescentes em outros grupos sociais, enquanto estão em acolhimento; revisão dos prontuários, incluindo a versão atualizada do adolescente sobre sua história de vida e das ressignificações realizadas e, por fim, espaço de escuta coletivo entre membros da equipe de uma unidade de acolhimento. Especificamente sobre o trabalho com histórias de vida, ele pode ser realizado utilizando-se da árvore genealógica, do projeto parental e do acesso às trajetórias de vida. Como limitação deste estudo, tem-se que ele focou o acesso às histórias de vida de adolescentes com longo tempo de institucionalização e que possuíam relação com uso de drogas, atos infracionais e vivência na rua.

Palavras-chave: adolescência; acolhimento institucional; histórias de vida. 


\begin{abstract}
Carvalho, B. J. C. (2015). Marked paths: life stories of adolescents with institutional care experience. Tese de Doutorado. Universidade de Brasília, Brasília
\end{abstract}

This text concerns a qualitative research on life stories of teenagers in residential care situation that have developed in order to understand the dynamics of teenagers who are welcomed and often evade the institution and are living on the streets, returning to the shelter later. The argument put forward has two dimensions, the first of which concerns the methodological dimension in which a mediator object of expression of the life story of teenagers, acts as a facilitator of the narrative and the second, it has to be the expression of the life story favors the reinterpretation of the story to the subject itself, and is therefore not only a method of research but an alternative to professional intervention. The theoretical framework that supported this work was that Psychosociology Clinic, conducted by Life Stories methodology, which is based on the clinical approach and seeks to understand a social phenomenon through access to the subjectivity of individuals that make up the situation investigated. The study participants were two teenagers, a boy and a girl, who were welcomed into an institution at the time, and a social worker who worked the unit. The teenagers narrated their life stories, over several meetings at the same time drew freely, which facilitated the expression of those stories. Regarding the social worker, she spoke of his career in a single meeting, without the need for any concrete evidence to mediate his speech. The analysis of these stories took place on two levels: descriptive and chronological level, which organized the stories in chronological order, by subdividing it into topics, from the most recurrent subjects found and thematic level, with the themes: process in response strategies social alienation; tension between the host institution and the street and, finally, organizational aspects of the residential care of adolescents. This analysis showed that teenagers can make use of individualized strategies to deal with the situation of being in a host institution, and, secondly, they start to make use of collective, group strategies to avoid membership in a group that is It is seen by society as being made up of children and adolescents from a family who failed in their care and protection functions. It is therefore important that professionals who work in a host institution have a clinical approach in care and monitoring of teenagers welcomed for accessing perceptions and feelings, creating, with the teenager, alternatives to the living. In this sense, this research suggests some forms of interventions that favor the clinic listening of professional hosting: group work with adolescents; Drawing use to facilitate the expression of life stories; entry of adolescents in other social groups, while on the host; review of medical records, including the updated version adolescent about his life story and made new meanings and, finally, collective listening space between team members of shelter. Specifically about working with life stories, it can be performed using the family tree, the parental project and access to life trajectories. One limitation of this study, has focused on access to adolescent life stories with long institutionalization and who had relationship with drug use, illegal acts and living on the street.

Keywords: adolescence; shelter; life stories. 


\section{INTRODUÇÃO}

Toda história coletiva é singular e universal. É a partir dessa premissa, pontuada por Carreteiro (2009) que se dá início a este projeto de pesquisa. A história de um grupo social é percebida de forma única por seus integrantes, o que lhes permite vivências singulares. Ao mesmo tempo, essa mesma história individual possui elementos que se repetem entre os componentes desse grupo, compondo a história coletiva do mesmo.

Pensando nas pessoas que integram um coletivo, cada uma possui uma história particular, uma vivência singular e que contém vários aspectos e elementos que a vão compondo ao longo dos anos de sua trajetória. Porém, essa pessoa está em constante interação com outras pessoas e com os contextos dos quais faz parte.

Assim que nasce, o indivíduo é inserido num primeiro grupo que irá propiciar cuidados mínimos para que ele sobreviva às diferentes situações enfrentadas. Esse grupo, que pode ser a família de origem, uma família substituta ou uma unidade de acolhimento institucional, por exemplo, também possui uma história que irá atuar diretamente na criança, mas não de forma unilateral, cabe salientar. Além do mais, antes de o menino ou menina nascer, pode ter havido expectativas e planos em relação àquela criança e que terá importância marcante em seu desenvolvimento pessoal e interpessoal.

Outro aspecto importante diz respeito ao grupo que acolhe a criança. Ele compõe e interage com outros grupos, seja de forma direta na própria comunidade, com escolas e igrejas etc, seja compondo um grupo maior, como o seu país. No caso do Brasil, representantes do povo por eleição, organizam Políticas Públicas, que afetam toda a população e são de ordem econômica e social, por exemplo. Além do mais, um país interage com outros países por meio de negociações, acordos internacionais, guerras, comércio, dentre outras formas de interação. 
Dessa forma, a história individual de uma pessoa não pode ser contemplada sem que os contextos e as formas de organização social dos quais ele faz parte, com a forma que se configuram, sejam considerados. Num movimento constante de interação e influência mútuas, a história individual e a história coletiva se fazem coexistir. Em outras palavras, aspectos subjetivos interferem no contexto social e a dimensão coletiva produz efeitos na experiência individual (Rhéaume, 2009). Sendo assim, para uma maior compreensão da história individual, a história coletiva precisa se fazer presente e vice-versa. Para o pesquisador, captar esses pontos de intersecção é essencial e proporciona uma avaliação mais ampla da situação.

Em relação a populações em vulnerabilidade psicossocial, observa-se muitas vezes intervenções profissionais que focam as pessoas e, quando muito, suas famílias, não levando em consideração aspectos da organização comunitária, social e política que interferem na vida desses indivíduos ou grupos. Com isso, observamos um elevado grau de frustração desses profissionais que não conseguem alcançar, junto a esse público, o grau de promoção de mudança e de autonomia, que eles observam como sendo importantes. Como uma das consequências, o sujeito que está em condição desfavorável social, econômica e politicamente, acaba sendo responsabilizado pelo não sucesso das intervenções técnicas. E isso marca sua constituição enquanto sujeito.

Porém, a partir de uma análise mais ampla das situações, ao considerar histórias individuais e histórias coletivas em constante interação, o processo de mudança parece ser mais eficaz. Quando o próprio sujeito adquire a consciência que suas vivências fazem parte de um contexto maior, de uma história que se iniciou antes mesmo do seu nascimento, ele pode agir de forma mais eficiente e eficaz em busca de mudanças sobre sua forma de ser e estar no mundo.

Uma forma de se promover essa maior conscientização é trabalhando a história de vida das pessoas e, nesse processo, ir percebendo com o próprio sujeito, aspectos da história 
coletiva que se fazem presentes e vice versa. Como indica Levy (2001), por meio do método da história de vida, é possível que se compreenda o funcionamento de uma sociedade a partir do seu interior, de um grupo social ou qualquer outro coletivo que apresente características comuns.

Ao revisitar a própria história, essa pode ser ressignificada e, no caso de populações vulneráveis, é possível que se inverta a lógica: uma história de vida que é apresentada inicialmente submissa às vivências de abandono, humilhação e desqualificação, pode sofrer mudanças no sentido de o indivíduo criar alternativas de superação da violência vivida e construir um projeto de vida que marque positivamente o caminho a ser trilhado.

Mas como acessar essas histórias? Numa pesquisa, pode ocorrer que se defina seus participantes e que, no método, seja apresentada uma ou várias etapas para coleta e análise de dados, pré-definidas em detalhes. Mas ao buscar acessar as informações do participante de forma padronizada e pré-definida, corre-se o risco de deixar escapar aspectos singulares desses sujeitos, pois consideramos que existem diferentes formas de ser, sentir, agir e interagir com o outro. Em relação às pesquisas com histórias de vida, é importante, então, que o pesquisador permita alguma flexibilidade no método de coleta dos dados, o que pode ser ajustado ao longo do estudo, facilitando a expressão de vivências singulares dos participantes.

A partir desse ponto, apresentamos este projeto de pesquisa. Propomos acessar histórias de vida, levando-se em consideração as vivências individuais dos participantes, que são únicas, identificando logo no início, junto a eles, a melhor forma de se expressarem. Além da forma verbal, alguns elementos apontados pelos sujeitos podem mediar o contato entre o pesquisador e o participante, facilitando o acesso a essas histórias, tais como desenhos e pinturas. 


\section{JUSTIFICATIVA}

Trata-se de pesquisa com Histórias de Vida, inserida em uma realidade contextual de adolescentes acolhidos em instituições por meio de medida protetiva de acolhimento. Essa medida é aplicada pelo Juiz da Infância e da Juventude que, em virtude de situações variadas de violação de direitos, encaminha a criança ou o adolescente temporariamente para uma instituição de acolhimento, conforme consta no inciso VII, art. 101 da Lei Federal n ${ }^{\circ} 12.010$ (2009). Nesse período de acolhimento, a equipe profissional da unidade, geralmente composta por psicólogo e assistente social, dentre outros, trabalha com o acolhido e com a família de origem no intuito de promover o retorno da menina ou menino ao meio familiar e facilitar sua inserção comunitária, encaminhando-os para a adoção somente como última alternativa.

Ocorre que é recorrente, nessas instituições, muitos adolescentes acolhidos evadirem da unidade e ficarem algumas horas, ou dias, na rua, geralmente nas proximidades da unidade, retornando em seguida para o acolhimento. Esses adolescentes apresentam certa dificuldade em respeitar as regras de convivência do acolhimento e em frequentar a escola, além do fato de os profissionais nem sempre conseguirem proporcionar o retorno deles ao convívio familiar (Arpini, 2003). Então, a fim de melhor compreender a dinâmica do processo de acolhimento de adolescentes, que se organizam de forma a ir e voltar da instituição para a rua e vice-versa, propomos a História de Vida como método de compreensão desse fenômeno (Gaulejac \& Ochoa, 2002). Conhecer melhor essa situação pode proporcionar a construção de alternativas, visando maior proteção e cuidado aos adolescentes acolhidos institucionalmente. A partir desse objetivo, escolhemos: acessar as histórias de vida de adolescentes e a trajetória profissional de um trabalhador da instituição, identificando-se elementos dessas trajetórias individuais que ecoam da e na realidade sócio-histórico-cultural vivenciada.

Este estudo ocorreu no Distrito Federal que apresenta hoje, com 55 anos de existência, a contar de sua fundação, uma população de 2.852 .372 habitantes, estimada a partir do Censo 
Demográfico do ano de 2010, realizado pelo Instituto Brasileiro de Geografia e EstatísticaIBGE (www.ibge.gov.br). Desse público, em torno de 790.000 são crianças e adolescentes, com faixa etária entre zero e 18 anos. Vale ressaltar a existência de grande número de famílias oriundas das regiões norte e nordeste do País, que buscam na Capital Federal melhores condições de vida.

Nesse contexto, ao mesmo tempo em que se podem identificar famílias com alto poder econômico e espaços com condições satisfatórias de habitabilidade, lazer, educação e saúde, no Distrito Federal, observamos também a presença de situações que dificultam a organização de outros grupos familiares, tais como condições precárias de saneamento básico em alguns locais de moradia, insuficiência nos atendimentos da rede pública de saúde, pouca opção para atividades de lazer e cultura em muitos locais, escolas públicas que nem sempre atendem às expectativas dos alunos e das famílias, insuficiência de creches públicas, alto preço cobrado para moradia, transporte e alimentação, dentre outros. Outros elementos importantes estão relacionados à pouca qualificação profissional dos membros de muitas famílias e a grande exigência de pelo menos o ensino fundamental completo para contratação em serviço no Distrito Federal.

Paralelamente, fica evidente a presença de diversos tipos de violação de direitos entre as pessoas que possuem condições precárias de habitabilidade e emprego, principalmente em relação às crianças e aos adolescentes, que podem ser observados segundo alguns dados. Entre os anos de 2007 e 2009, existiam 545 pastas especiais em trâmite na Promotoria de Justiça de Defesa da Infância e da Adolescência do Distrito Federal (Fukuda, Penso \& Santos, 2013). Essas pastas, que dizem respeito aos casos de aplicação de medida protetiva de acolhimento, segundo previsto no Estatuto da Criança e do Adolescente, alterado pela Lei Federal $\mathrm{n}^{\mathrm{o}} 12.010$ (Brasil, 2009), estavam relacionadas às 1.002 crianças e adolescentes acolhidos institucionalmente entre os anos 2007 e 2009. 
Em outras palavras, mais de 1.000 crianças e adolescentes tiveram seus direitos violados de forma importante, o que necessitou da aplicação de medida judicial protetiva de acolhimento institucional. Isso sem contar as violações supostamente com menor poder ofensivo que ocorrem às crianças e aos adolescentes e que não indicam a necessidade do acolhimento. Há ainda, as situações de violência que sequer são identificadas pelo poder judiciário, mas que também marcam profundamente as histórias desses meninos e meninas.

Compondo essa cidade tão nova e ao mesmo tempo, tão complexa e com tantas incongruências sociais, um público se faz presente. São adolescentes que possuem em sua trajetória de vida uma vivência importante: acolhimento em abrigo institucional ou casa lar e que passam longo tempo do dia ou da semana na rua. Essas histórias de vida precisam de olhares atentos para que se possa compreender elementos significativos em relação às várias situações de desproteção ocorridas a esses meninos e meninas ao longo de suas trajetórias de vida. E os próprios adolescentes podem contribuir para um melhor entendimento dessas vivências.

Por fim, é nesse ponto que minha história enquanto pesquisadora da presente pesquisa se cruza com as histórias desses adolescentes. Com formação em Psicologia, ainda na graduação, trabalhei com crianças e adolescentes que se encontravam em situação de rua na Asa Norte - Brasília, Distrito Federal. Depois, ao ser aprovada em concurso público para a Secretaria de Desenvolvimento Humano e Social - SEDHS (que à época chamava-se Secretaria de Estado de Desenvolvimento Social e Transferência de Renda do Distrito Federal- SEDEST), continuei a trabalhar com situações de violação de direitos em populações vulneráveis, coordenei uma unidade de acolhimento para crianças e adolescentes, esses acolhidos com medida protetiva, além de também coordenar, posteriormente, outra unidade que acolhia adolescentes e jovens com trajetória de rua. 
Nessa trajetória profissional, observei que na primeira unidade de acolhimento, muitos adolescentes tinham dificuldades em permanecer no abrigo institucional e evadiam para a rua, muitas vezes sem retorno àquela unidade. Já na segunda unidade, que recebia em sua grande maioria, adolescentes em situação de rua, ficou evidente a presença de muitos meninos e meninas que já haviam passado por outras instituições de acolhimento mais formais e rígidas em suas regras. Esses adolescentes fugiram desses abrigos institucionais ou casas lares por não se adaptarem ao tipo de funcionamento dessas instituições.

Procurando entender melhor o que estava acontecendo, ao coordenar a primeira unidade, comecei a ouvir a história de vida de um adolescente visto como "problema" e "sem jeito" pela maioria da equipe da unidade de acolhimento. Depois, esse adolescente foi para a unidade que acolhia meninos e meninas em situação de rua e, antes de assumir a coordenação do local, por já haver um vínculo com esse adolescente, passei a trabalhar a história de vida dele e junto dele. O objetivo era compreender e favorecer a compreensão ao próprio adolescente, de uma história marcada por diversos abandonos e situações de violência.

Assim, observei que, enquanto o adolescente desenhava (era uma habilidade que ele possuía), ele conseguia verbalizar as várias situações de violência pelas quais havia passado e, com o decorrer dos encontros, algumas ressignificações e expressão de afetos puderam ser identificadas. Como uma espécie de distanciamento da própria história, foi possível nesse processo, que tanto planos para o futuro, como um projeto de vida, começassem a ser estruturados.

Também, junto a esse mesmo adolescente, pude identificar elementos do contexto social que compunham as trajetórias de vida de outros adolescentes que possuíam longas trajetórias de acolhimento institucional. Acessei, então, uma trajetória individual interligada à trajetória de uma sociedade que nem sempre protege suas crianças e adolescentes, produzindo marcas profundas na singularidade e da identidade desses sujeitos. 
A partir desta experiência, essa pesquisa de doutorado foi organizada, no intuito de favorecer a construção de histórias de vida de adolescentes que tinham em suas trajetórias de vida o acolhimento institucional, com vivência de rua nesse mesmo período, além da construção da trajetória profissional de um trabalhador do serviço de acolhimento. Por meio do uso de elementos mediadores junto aos adolescentes, de acordo com as singularidades de cada participante, buscou-se facilitar a expressão das vivências e a identificação de suas implicações para a subjetividade desses sujeitos e a coletividade na qual estavam inseridos.

A orientadora da pesquisadora, $\operatorname{Prof}^{\mathrm{a}} \operatorname{Dr}^{\mathrm{a}}$ Liana Fortunato Costa, é Docente Permanente do Programa de Pós-Graduação em Psicologia Clínica e Cultura da Universidade de Brasília - UnB, e integrante do projeto de pesquisa intitulado "Crianças e adolescentes abrigados no Distrito Federal: estudos das condições familiares, institucionais e sociais”. Este projeto tem como responsável a $\operatorname{Prof}^{\mathrm{a}} \mathrm{Dr}^{\mathrm{a}}$ Maria Aparecida Penso, pela Universidade Católica de Brasília - UCB e buscou conhecer as condições familiares, institucionais e sociais das crianças e adolescentes constantes dos processos de acolhimento institucional em andamento na Promotoria de Justiça de Defesa da Infância e da Juventude, visando contribuir para a sistematização de novos procedimentos que possibilitem uma melhor garantia do direito à convivência familiar e comunitária dessas crianças e adolescentes. Assim, esta presente pesquisa integra a pesquisa interinstitucional apresentada acima, contribuindo com a investigação por meio do acesso às histórias de vida de adolescentes que possuem, além do acolhimento institucional, vivência de rua.

\subsection{Objeto de estudo}

Como objeto desta pesquisa, tem-se histórias de vida de adolescentes em situação de acolhimento institucional. 


\subsection{Objetivos da pesquisa}

A partir do contexto apresentado, esta pesquisa buscou, como objetivo geral, compreender a dinâmica de adolescentes que se encontram acolhidos em um abrigo institucional, que com frequência evadem da instituição e ficam morando na rua, retornando para o acolhimento tempos depois. No intuito de alcançar seu objetivo, o processo de investigação abarcou os objetivos específicos abaixo:

a. Acessar as histórias de vida dos adolescentes participantes;

b. Acessar a trajetória profissional de uma assistente social que trabalha em um abrigo institucional onde os adolescentes participantes já foram acolhidos;

c. Identificar elementos das trajetórias individuais dos participantes que ecoam da e na realidade sócio-histórico-cultural vivenciada.

Assim, a partir desse ponto, deu-se início ao estudo teórico que fundamentou a pesquisa e propiciou seu andamento com vistas a melhor compreensão do fenômeno estudado. Em seguida, organizou-se um método de investigação que possibilitasse chegar aos objetivos propostos, sempre de acordo com a base teórica escolhida.

\subsection{Tese}

A tese que se pretende defender ao longo deste estudo possui duas dimensões. A primeira diz respeito à dimensão metodológica, na qual um objeto mediador na expressão da história de vida de adolescentes, mediador este indicado pelo próprio participante da pesquisa, e não imposto pelo pesquisador, atua como facilitador da narrativa.

Assim, decorrente da primeira dimensão, apresenta-se uma outra: a expressão da história de vida favorece a ressignificação dessa história para o próprio sujeito, sendo, portanto, não somente um método de pesquisa mas uma alternativa de intervenção profissional junto a adolescentes com vivência de acolhimento institucional e de rua. 


\section{FUNDAMENTAÇÃO TEÓRICA}

O presente capítulo indica as bases epistemológicas e teóricas desta pesquisa, realizada por meio da metodologia de Histórias de Vida, tendo como base uma abordagem clínica. A importância de se ter explícito esse embasamento se justifica pela possibilidade que oferece ao pesquisador de ter mais clareza no que concerne ao fenômeno estudado, utilizando um método condizente com os pressupostos que estão subjacentes a todo o processo de investigação.

Apresenta-se também uma delimitação conceitual e contextual pois, como indicou Rhéaume e Roy (2000), a escolha de qualquer campo de pesquisa implica em uma delimitação fundamental da configuração social sobre o fenômeno estudado, o que inclui as características da população envolvida e a definição clara dos conceitos utilizados. Implica também na localização social das categorias utilizadas, o que, no caso desta pesquisa, significa indicar o que está envolvido legalmente enquanto medida de proteção em acolhimento institucional para adolescentes. Essa previsão legal orienta as intervenções dos profissionais que trabalham especificamente nesse contexto.

\subsection{Psicossociologia Clínica}

As Histórias de Vida trabalhadas nesta pesquisa têm como base teórica a Psicossociologia Clínica, que busca compreender um fenômeno social por meio do acesso à subjetividade de indivíduos que compõem a situação investigada. Ao se identificar o processo singular de construção da subjetividade, também se evidencia elementos do contexto social ao qual o sujeito faz parte, já que um é constituído em relação ao outro. Assim, se ao conhecer uma História de Vida pode-se conhecer e analisar elementos do contexto social que perpassam essa construção, bem como as transformações que ocorrem tanto no indivíduo quanto na 
sociedade (Houle, 1986). Em outras palavras, pode-se acessar o processo de constituição de uma sociedade quando se conhece o processo de constituição de uma História de Vida, já que ambos ocorrem simultaneamente, um atravessando o outro, influenciando e sendo modificado por esse outro.

\subsubsection{História de Vida}

Um ponto a esclarecer é em relação ao termo História de Vida. O termo original é récit de vie, do francês, que se traduz em português em história de vida (Rhéaume, 2013). Mas há uma conotação na língua francesa importante a ser colocada que se perde com a tradução. A palavra histoire está mais ligada à exposição de fatos ou sucessão de eventos, de forma objetiva, que busca divulgar um acontecimento sem considerar os sentimentos e as percepções presentes. Essa palavra está, geralmente, ligada às diversas situações presentes na construção e transformação das sociedades ao longo do tempo, aos grandes eventos, como os de guerra, os denominados fatos históricos. Esses são divulgados como sendo a versão oficial do que se passou e estão organizados, atualmente, em uma disciplina específica, a História, que estuda esses grandes acontecimentos. Mas a palavra récit possui outro significado (o qual é utilizado nesta pesquisa) que está relacionado à narração subjetiva da própria história de vida a outra pessoa, sobre os fatos vividos e presentes na memória de quem narra, sendo eles relacionados a fatos concretos ou imaginários. Assim, ao se ler o termo História de Vida neste texto, que fique claro que o sentido aqui presente é o de récit de vie, mas vale ressaltar que alguns teóricos vão utilizar em seus textos o termo História de Vida também com o sentido de récit de vie.

Em termos históricos (Legrand, 1993), a pesquisa por meio de histórias de vida tem sua origem em duas disciplinas distintas, a Antropologia Cultural e a Sociologia. Na Antropologia Cultural, ela fez-se presente em investigações norte-americanas em tribos 
indígenas e na busca de histórias de grandes chefes índios, entre os anos de 1926 e 1945. Após esse período, essa abordagem começou a enfraquecer no meio acadêmico. E na Sociologia, uma referência crucial é a Escola de Chicago, fundadora da Sociologia empírica americana. Após muitas pesquisas entre os anos de 1920 e 1940, o uso das histórias de vida em pesquisa também ficou enfraquecido nos Estados Unidos. Uma hipótese para esse enfraquecimento é o momento pós Segunda Guerra Mundial, quando o mundo acadêmico passa a valorizar somente métodos quantitativos e entrevistas realizadas por meio de questionário.

Somente nos anos 1970, pesquisas que se utilizam de histórias de vida vão voltar à cena graças à publicação da obra intitulada Histoire de vie: ou récits de pratiques?, do sociólogo francês Daniel Bertaux (1976), onde ele apresenta um panorama e uma avaliação sobre pesquisas que se utilizaram do método biográfico, além de algumas conclusões a que chegou após diversas experiências de acesso a histórias biográficas. A partir desse texto, o interesse pelas histórias de vida como método de investigação científica voltou a crescer no meio acadêmico, perdurando até os dias atuais (Legrand, 1993).

\subsubsection{Abordagem Clínica}

Dentre os teóricos que vão participar ativamente desse movimento de reavivamento das histórias de vida, enquanto método de investigação, temos Vincent de Gaulejac, sociólogo francês que organizou a Sociologia Clínica. A proposição teórica dessa pesquisa possui forte influência da Sociologia Clínica, que, assim como a Psicossociologia Clínica, como o nome já indica, são ancoradas em uma abordagem clínica. Então, Vincent de Gaulejac lança um olhar clínico ao vivido pelos atores sociais, considerando, assim, o conhecimento acumulado por esses atores ao longo dos anos para analisar e compreender a sociedade (Gaulejac \& Hanique, 2012). 
Apresentando uma epistemologia pluralista, muitos teóricos favoreceram a organização da Sociologia Clínica, indicando a possibilidade de aproximação entre a Sociologia e a Psicologia. Dentre eles, tem-se o sociólogo Émile Durkheim que, implicitamente, em sua obra, indica que fatos sociais são também fatos psíquicos, enfatizando o papel essencial das crenças e das paixões na vida coletiva. Outro sociólogo importante é Marcel Mauss, que apontou a necessidade de se considerar o campo clínico na Sociologia, sendo importante, então, para a compreensão de um fenômeno social, abarcar o vivido de cada indivíduo, com os sentidos que ele lhe confere, seus sentimentos e emoções, sempre vendo esse sujeito como protagonista de sua própria história. Também Cornelius Castoriadis, com a visão de sujeito sociohistórico e Edgar Morin, com a noção de complexidade, são referências importantes para a Sociologia Clínica. Complexidade, para Morin, diz respeito a aspectos de um conceito que são tecidos, que repousam tanto em uma como em outra dimensão. Assim, esses autores vão buscar identificar os pontos de ligação entre indivíduo e sociedade, o imaginário e a realidade, objetividade e subjetividade, psíquico e social (Gaulejac, 2012).

A Sociologia Clínica é, então, uma abordagem que considera os fenômenos sociais como multidimensionais (Gaulejac, 2012), pois não abarca somente o coletivo, mas também a dimensão psíquica, individual. Também enfatiza que o vivido dos atores sociais remete à questão da fronteira entre Psicologia e Sociologia, o externo e o interno, a objetividade e a subjetividade. A proposta, então, se situa na intersecção entre esses opostos, buscando esse encontro de contrários, a ligação, os pontos em comum e os complementares, os elementos que se fazem presentes em ambas as dimensões. Como exemplo, temos a contribuição importante da história social e familiar no processo de construção identitária de um indivíduo. Outro exemplo é em relação ao sentimento de vergonha, que pode ser avaliado a partir de, pelo menos, três perspectivas: a perspectiva moral, relacionando-o às normas fixadas pelo 
meio no qual se faz parte; a existencial, ligada à ameaça à estima de si mesmo, com efeitos diretos na identidade do indivíduo em que o mais importante é não ser estigmatizado e, por consequência, excluído; e a social, que possui efeitos de controle sobre esse indivíduo na medida em que marca sua identidade social e evita que um sujeito não siga as normas e valores de uma sociedade. Com isso, pela perspectiva social, o sentimento de vergonha possibilita maior coesão entre as pessoas de um mesmo grupo ou de uma sociedade. Essas três perspectivas, pela ótica da Sociologia Clínica, não são excludentes entre si, mas complementares, pois evidenciam vários elementos em relação à vergonha e ao desejo de reconhecimento e aceitação de uma pessoa num dado contexto social (Gaulejac, 2006).

Diante do exposto, o pesquisador deve ter em mente que ao incluir a dimensão clínica, da subjetividade, em uma pesquisa, quer seja por meio da Psicossociologia ou da Sociologia Clínicas, tem-se a premissa de que o saber científico é importante, mas não o mais importante. Não é defendida a hierarquização dos saberes, com o saber científico como o mais adequado na compreensão de uma situação. Ao contrário, a postura clínica se constrói pela escuta e valorização do saber relacionada à experimentação, considerando também o conhecimento que os atores sociais têm do seu mundo social. Com a valorização de diferentes pontos de vista, favorece-se um espaço de co-construção do saber. Vale salientar que o saber científico não é recusado, mas busca evitar o uso da violência simbólica que pode ser instaurada entre os que sabem e os que não sabem. A compreensão dos fenômenos sociais ocorre com a análise que contém um movimento de ir e vir entre a experiência e a teoria, o experimentado e o reflexivo, o vivido e o conceitual (Gaulejac \& Hanique, 2012).

Nesse cenário (Rhéaume, 2012), a abordagem clínica não valoriza a organização desigual entre os saberes, mas busca um encontro, no caso da pesquisa com histórias de vida, entre as experiências tanto do pesquisador quanto do participante. Ferrarotti (1990b) complementa indicando a necessidade de uma interação entre pesquisador e participante da 
pesquisa, numa relação de igualdade que permite ao pesquisador e ao grupo pesquisado, uma comunicação não somente coerente metodologicamente com os pressupostos utilizados, mas também humana.

É essencial, então, em pesquisas que utilizem uma abordagem clínica, que o pesquisador assuma uma postura de igualdade em relação ao participante da pesquisa, considerando o saber do outro tão importante na compreensão do fenômeno estudado quanto o saber científico. Essa postura não ignora que os diversos tipos de saberes possuem especificidades entre si. Rhéaume (2012) aponta que, em linhas gerais, tem-se três tipos de saberes no contexto da pesquisa e intervenção em práticas sociais: o acadêmico ou científico, o saber prático dos profissionais de intervenção, ou gestão, e o saber da experiência e de senso comum dos usuários e consumidores de bens e serviços, ou membros da população em geral. Além desses, existem os saberes estético e espiritual, dentre outros. Mas na prática é difícil estabelecer uma relação igualitária tanto entre os saberes de um mesmo tipo, por exemplo, entre os diversos saberes acadêmicos acumulados por diferentes abordagens, quanto entre as diferentes formas de saber, ou seja, entre os saberes científicos, práticos e de senso comum, dentre outros.

Outro ponto fundamental relacionado à abordagem clínica, é que essa investigação corresponde a um tipo de pesquisa ligada à ação e à prática social (Rhéaume, 2012). Legrand (1993) indica que a expressão de uma história de vida não corresponde à descrição objetiva do vivido, mas o ato de contar a própria história é uma construção ou reconstrução da vida e dessa história. É um trabalho complexo pois, o sujeito, que é histórico, na medida em que produz a própria história, é produzido por ela concomitantemente. O sentido em relação ao que se viveu é sempre reconstruído pelo ato de contar a própria história, há sempre uma ressignificação nesse momento. 
Grell (1986) pontua que uma entrevista sobre História de Vida apresenta uma experiência, mas ela em si é uma experiência também, pois o narrador estabelece uma relação com ele mesmo e o pesquisador. E isso inclui o que contar e o que enfatizar, e qual leitura o narrador faz naquele momento do que está contando. Mas para que a narração de uma história, de uma trajetória, ocorra plenamente, é importante que o participante da pesquisa deseje contá-la. Para facilitar esse processo, o pesquisador precisa pontuar claramente o que quer saber.

Nesse contexto, tem-se como proposta a transformação do termo clínica, que tem em sua origem o sentido de estar próximo ao leito de uma pessoa doente para ajudá-la, já que a palavra grega klinè significa leito. No caso da abordagem clínica, então, a noção de proximidade e de implicação em relação ao outro se aplica no contexto social, por meio de intervenções ou pesquisas com pessoas ou grupos sociais. Ao possibilitar ao outro o acesso às suas experiências, ao seu vivido, há maior compreensão por ele do que se passou, maior conhecimento sobre esse vivido. Com isso, há maior possibilidade dele se tornar mais ativo na construção da própria história futura, num papel de ator social, fazendo escolhas de forma mais clara e consciente (Rhéaume, 2012). Como acrescentou Sévigny (2001), a clínica em Ciências Humanas não se preocupa somente com determinado problema, mas também com a pessoa envolvida em tal questão.

Os métodos clínicos são construídos, então, para permitir ao sujeito expressar sua história de vida, analisar conflitos vivenciados e criar respostas face às contradições identificadas. Contradições essas presentes nas trajetórias sociais, mas que, muitas vezes, se traduzem em conflitos psíquicos (Legrand, 1993). Assim, por meio da expressão da história de vida, pode-se acessar não só as diferentes posições sociais ocupadas pelo indivíduo ao longo de sua vida, como por exemplo, o desempregado, o toxicômano ou usuário da política 
pública de assistência social dentre outros, mas também, indica a trajetória subjetiva desse indivíduo, ou seja, um trabalho interior de construção da própria identidade (Bellot, 2000).

Em pesquisa com crianças em situação de acolhimento institucional na França, por meio do método da História de Vida, Abels-Eber (2000) identificou que essas crianças se sentiam responsáveis pela próprio acolhimento, mas, ao longo dos encontros, elas puderam apreender a dinâmica familiar e social que as conduziram para aquela situação. Tal trabalho possibilitou que saíssem do lugar de se culpabilizarem pelo afastamento em relação aos pais, restituindo a cada um a própria responsabilidade e permitindo que, ao não focar no passado, as crianças olhassem para o futuro de forma mais tranquila e com maiores possibilidades.

O pesquisador precisa, então, ir o mais próximo possível do vivido dos atores para conduzir essa análise e buscar compreender o que se propôs em sua pesquisa, num processo de proporcionar que o participante compreenda a própria história e responda às questões que vão emergindo (Gaulejac \& Hanique, 2012). A coerência do processo ocorre ao se dar lugar tanto o conhecimento intelectual quando ao conhecimento sensível, entre a reflexão e o registro do vivido. Então, para acessar esse ponto em comum, a postura clínica do pesquisador, que possibilita uma escuta próxima do vivido pelo outro, é essencial.

É importante favorecer a empatia, a compreensão mútua, a co-construção de hipóteses, a confrontação de saberes teóricos, práticos e experimentados. Deve-se favorecer a implicação e, ao mesmo tempo, o distanciamento do pesquisador. Nesse sentido, é preciso propor suportes metodológicos que favoreçam essa exploração, construindo instrumentos de apoio e mediação necessários. É importante uma boa postura entre a proximidade e a distância, entre a atenção ao vivido e a análise das determinações sociais presentes, entre o sujeito como um agente de historicidade implicado num processo de produção da sociedade e a análise das condições de seu assujeitamento (Gaulejac, 2012). 


\subsubsection{Historicidade}

Para a Psicossociologia Clínica, todo sujeito é um ser histórico na medida em que, por mais que seja de alguma forma programado por sua história, possui uma singularidade, uma capacidade de reescrevê-la. Nesse contexto, a historicidade então está relacionada com a função que permite ao sujeito distanciar-se da sua história, tomar consciência de como os fatores sociais, culturais, de classe, econômicos, familiares atuaram e determinaram sua trajetória, muitas vezes levando-o a agir de determinada forma, modificar o sentido desses determinantes, reprogramando sua maneira de estar no mundo e agir de forma diferente no futuro. Para isso, ele precisa considerar a necessidade de criação de estratégias sociais condizentes com a evolução da sociedade ao qual faz (Gaulejac, 2005c).

Considerando então a função da historicidade, pode-se compreender porque, mesmo em condições objetivas de existência semelhantes, duas pessoas podem compreender e significar suas histórias de forma diferente. E cada história possui e pode possuir vários significados ao longo do tempo, considerando que o futuro é indeterminado e que o comportamento humano é relativamente imprevisível (Gaulejac, 2005c). A fim de se compreender a relação que o indivíduo possui com sua história, é imprescindível que se analise o sistema social ao qual integra, o tempo em que se encontra e o espaço que ocupa, condicionando-o como ser histórico-social.

Em relação à historicidade vista de um ângulo coletivo, ela refere-se à ação que a sociedade exerce sobre ela mesma, pelo conhecimento e pela representação que possui sobre si. As sociedades possuem uma história, pois, ao produzir modelos culturais, permitem uma interpretação do futuro, num movimento entre produção e reprodução, ordem e movimento, limites impostos por meio da cultura e dos modelos de conhecimento e as rupturas produzidas por desequilíbrios internos. Tem-se então a historicidade coletiva como um conjunto de processos, em que a sociedade produz sua própria história. Toma-se, por exemplo, um termo 
de Karl Marx do século XIX, o de classe social. Esse conceito indicava que havia uma tensão entre as classes sociais de uma sociedade, que se relacionam de formas antagônicas, em que a classe dirigente tornava-se a classe dominante em contraposição às demais classes, na medida em que impunha seu modelo cultural e suas orientações para toda a sociedade, buscando atender seus próprios interesses. As outras classes, dominadas, também denominadas de proletariado, buscavam defender-se de várias maneiras contra os interesses da classe dominante.

Atualmente, essa dinâmica é denominada por Gaulejac (2005c) de relações sociais de desigualdade. Não há uma consciência de classe entre as pessoas, mas os conflitos sociais persistem, confirmando que a desigualdade social está presente ainda hoje. O proletariado de antes refere-se aos "excluídos" de hoje, sendo aqueles que não são aceitos pela sociedade de forma geral por não alcançarem os padrões de produtividade e excelência esperado na atualidade. Assim, as relações de dominação de antes são percebidas hoje como relações de desigualdade, uma concepção mais subjetiva, mas que provoca vários conflitos sociais. E essa tensão presente nos conflitos sociais, marca a história de cada indivíduo, de acordo com o lugar social que ocupa.

Ferrarotti (1990a) pontua que a história de um contexto social é também a história do cotidiano de pessoas, de grupos desconhecidos pela grande história da humanidade, mas que compõem todo o processo histórico. Assim, cada narração biográfica, conforme apontou Ferrarotti (1990c), não trata somente de uma vida, mas das múltiplas interações que ocorreram entre indivíduos, instituições e grupos e que são contadas por intermédio dessa vida.

A questão central de um estudo, nesse contexto, está na compreensão da relação da subjetividade dos indivíduos na construção de suas relações sociais e de seus papéis enquanto atores sociais. Ou também de forma inversa, estuda os efeitos estruturantes das relações 
sociais sobre o desenvolvimento dos sujeitos em seus vínculos coletivos (Rhéaume, 2007). Bellot (2000) complementa ao indicar que a narração biográfica permite uma leitura das estruturas coletivas que orientam relações sociais específicas, ao mesmo tempo em que oferece uma leitura da atuação do indivíduo nesse contexto.

Os diferentes grupos nos quais o indivíduo integra, seja a família, o grupo de pares, a escola ou um abrigo, por exemplo, participam da construção da subjetividade desse indivíduo, ao mesmo tempo em que participam da dimensão estrutural de um sistema social. O grupo media e reproduz o contexto social mais amplo por meio de suas relações de poder e de comunicação, de suas normas e sanções e de suas modalidades de relações afetivas. Isso vai ser filtrado e interiorizado pelos indivíduos que o compõem. Mas, por mais que cada um tenha sua própria leitura do grupo ao qual faz parte, existe um compartilhamento de aspectos da leitura do grupo entre seus membros, ou seja, pontos em comum nessa leitura. Percebe-se, então, como indicou Ferrarotti (1990c), que os grupos, instituídos nas sociedades atuais, possuem atuação fundamental no psiquismo dos indivíduos.

Assim, a pesquisa em Psicossociologia Clínica possui como um de seus métodos a História de Vida, que permite o acesso a elementos tanto da subjetividade dos participantes quanto do social, bem como do processo histórico que se faz presente. Vale ressaltar que essa história não se resume na junção de fatos vividos pelo indivíduo, mas apresenta quais significados as ações possuem para esse indivíduo e quais os sentimentos envolvidos. Ao contar a própria história, aparecem, então, lembranças familiares, impressões e sentimentos em relação ao vivido, organizados pela percepção que o indivíduo possui ao contar sobre sua trajetória naquele momento. E também, esse tipo de pesquisa pode favorecer que o participante empregue novo sentido ao passado, ao vivido (Grell, 1986).

Por fim, a diferenciação entre Psicossociologia Clínica e Sociologia Clínica, conforme apontou Rhéaume (2013), ocorre na medida em que a Sociologia Clínica foi organizada 
posteriormente, a partir dos pressupostos da Psicossociologia, tendo o psicossociólogo Max Pagés como um teórico importante nessa construção. Dessa forma, um viés clínico passou a compor a Sociologia no processo de compreensão de um fenômeno social.

Então, considerando que a Psicossociologia Clínica aborda, em sua análise, o sofrimento humano interligado a contextos sociais, a pesquisa por meio de histórias de vida é um campo privilegiado de compreensão de fenômenos sociais e subjetivos inter-relacionados. No caso desta pesquisa, por meio da História de Vida de adolescentes com vivência de acolhimento institucional e de rua, e da trajetória profissional de uma assistente social, pôdese compreender melhor o fenômeno de adolescentes que, estando num lugar que supostamente oferece proteção, escolhem passar grande parte do seu tempo na rua. Como afirmou Le Grand (2005, p. 275): "no sentido mais genérico da expressão, a história de vida é uma pesquisa e uma produção de sentido relativo à vida de uma pessoa, vida considerada na sua duração".

\subsection{Construção identitária}

Antes de se discutir sobre a questão identitária, é importante situar o momento sociohistórico do qual se faz parte e que se refere ao tratamento deste assunto, incluindo suas principais características. Com essa localização, será possível clarear ao leitor de que modo essa organização social interfere na construção da identidade de cada indivíduo. Assim, segue uma breve explanação sobre a hipermodernidade, além de se apresentar o conceito de identidade utilizado neste estudo. 


\subsubsection{Hipermodernidade}

A Hipermodernidade é uma tendência ideológica que procura compreender os fenômenos sociais e individuais, presente em muitas sociedades atuais. Mas vale salientar que existem também outras tendências, que possibilitam outras leituras sobre o coletivo, mas que não serão apresentadas neste estudo. Ampara-se o olhar sobre o fenômeno estudado pelo ótica da hipermodernidade, cujas principais características são apresentadas a seguir.

Sob o conceito de Hipermodernidade, observa-se uma crescente exigência aos sujeitos de serem cada vez mais eficientes e adaptáveis à qualquer mudança, sendo obrigatório para isso que se tenha uma reação imediata, instantânea, em qualquer situação. Não é suficiente ir cada vez mais rápido, mas é necessário dominar o tempo para se tirar o maior lucro possível, produzindo o máximo no menor tempo. Dois elementos influenciaram essa dinâmica: a economia, com o capitalismo buscando lucro no mercado financeiro em curto prazo, e a tecnologia das comunicações, possibilitando trocas de informações e ampliação da rede de pessoas conhecidas, de forma instantânea. De forma geral, são características marcantes nesse período: respostas instantâneas e imediatas num contexto de urgência (Aubert, 2012).

No universo profissional, muitos vivem em um clima de urgência permanente, não conseguindo estabelecer uma hierarquia de prioridades. Tudo é extremamente urgente, e deve-se reagir de forma imediata e eficaz (Aubert, 2012). Nesse sentido, pode-se compreender o paradoxo de muitas instituições em organizar um planejamento de suas ações a longo prazo e estabelecer prioridades, tendo em vista que utilizam um tempo considerável buscando resolver questões urgentes. Essa é uma situação que pode ser identificada, muitas vezes, em unidades de acolhimento de crianças e adolescentes as quais, em meio à necessidade de respostas rápidas e eficientes, os profissionais, paradoxalmente, precisam construir e colocar em prática um projeto de vida com foco no futuro junto aos acolhidos. $\mathrm{E}$ essa realidade pode ser intensificada em unidades governamentais pois, como indicou Fortier 
(2012), há uma tendência das ações governamentais serem organizadas a curto termo, em meio a constantes mudanças políticas, estratégicas e de orientação que se fazem presentes.

Em relação à ampliação da rede de relações, possibilitada pela tecnologia, uma característica marcante dessas relações deve ser considerada: a rapidez, a efemeridade e a flexibilidade dessas relações. Existe uma dificuldade no estabelecimento de relações sociais duráveis, reflexo do que é valorizado atualmente: ter, estabelecer e fazer algo no menor tempo possível. E, também, se antes o indivíduo buscava uma realização de si, hoje o foco, ligado ao ideal do progresso, é o da superação de si mesmo em que se procura sempre ser o melhor. Mas essa busca da própria superação traz alguns prejuízos por causa do excesso de estresse, de solicitações e de pressões aos quais se submete. E com uma busca constante pela melhor performance de forma imediata, observa-se tanto uma dificuldade em se projetar no futuro, quanto o desenvolvimento de comportamentos extremos, ou de risco, como a toxicomania ou a realização de esportes radicais (Aubert, 2012).

Mas da mesma forma que existe uma valorização do excesso, que marca o individualismo contemporâneo, como o hiper-urgente, hiper-desempenho e hiper-lucro, existe também outro extremo que atua na construção identitária, o da falta: falta de reconhecimento, falta de segurança, falta de pertencimento. Enquanto uns são marcados pelo excesso, outros o são pela falta, como se o indivíduo só pudesse se expressar socialmente por meio desses dois extremos, marcando então a identidade hipermoderna. Assim, cada indivíduo é obrigado a ser no excesso, para não ser na falta, no vazio (Aubert, 2012). Então, cada um é responsável pela realização de si mesmo, numa perspectiva individualista. (Parazelli, 2000). E os que não conseguem gerenciar a própria vida em busca da realização de si mesmo, são condenados a viverem seu fracasso. Nessa sociedade paradoxal, o lugar da excelência existe em referência ao lugar do fracasso, ou seja, está-se em uma sociedade que exclui uns para valorizar outros (Gaulejac, 2007b). 
Guareschi (2010) reforça que o processo que pode levar à exclusão ainda é presente e forte em nossa sociedade pois, em relação à liberdade pregada pelo liberalismo e neoliberalismo, onde as pessoas têm o direito de fazer escolhas, podem trabalhar ou não trabalhar, podem escolher o local de trabalho, faz-se presente também a competitividade, componente essencial num cenário de liberdade econômica e de livre concorrência. Ocorre que num contexto competitivo, que para o liberalismo e o neoliberalismo é indispensável para o progresso e o desenvolvimento das sociedades, não há espaço para que todos ocupem o mesmo lugar, sendo então a exclusão, contrária mas complementar à excelência, uma situação sempre presente e necessária para a manutenção do sistema.

Nesse contexto, o trabalho por meio de histórias de vida pode favorecer ao indivíduo um olhar mais cuidadoso sobre sua própria trajetória, no qual ele poderá encontrar algum sentido para uma vida marcada pelo excesso ou pela falta. Pode auxiliar também a esse indivíduo que reconstitua uma compreensão e uma coerência sobre a própria vida, percebendo com mais clareza seu lugar numa sociedade hipermoderna (Aubert, 2012). Assim, pode-se abrir um leque de possibilidades de reagir à ideologia dominante, por meio de estratégias de resistência a essa imposição.

\subsubsection{Identidade}

É importante se deixar claro qual o conceito de identidade empregado nesta pesquisa e, para isso, utiliza-se das contribuições da Sociologia Clínica. Para Gaulejac (2001b), o nome de uma pessoa já indica algumas questões relativas à identidade. $\mathrm{O}$ nome está relacionado à singularidade daquele sujeito, enquanto que o sobrenome tem relação com sua filiação, num sentido de pertencer a determinado meio familiar. Mas essa filiação comporta também traços das aspirações dos pais e de deus ascendentes em relação ao filho ou a filha, que opera num duplo movimento para o sujeito. Esse fica entre seguir a tradição familiar, numa postura de 
reprodução de modos de ser e de fazer, ou se posicionar fora dessa herança, criando outras alternativas.

O trabalho com Histórias de Vida é interessante nesse contexto, pois permite ao indivíduo, ao ter consciência de fazer parte de uma herança familiar subjetiva, se organizar psiquicamente de outra forma, fora dos padrões familiares. Ao ter consciência de como essa história familiar que comporta elementos sociais, age sobre si, ele pode trabalhar sobre essa questão e gerenciar os elementos presentes de forma mais clara nessa trama. Assim, tem-se que o destino humano está relacionado ao trabalho que ele faz sobre si, sobre sua história.

E o conceito de identidade narrativa aparece no sentido de, ao narrar a própria história, o sujeito poder ter mais consciência dos elementos que atravessam sua história e gerenciá-los de uma forma mais clara, com mais autonomia. Muda a forma como o passado age sobre ele próprio, tornando-se assim, sujeito de sua própria história. Uma questão importante é que na narração de uma história, não há apenas a descrição de uma situação, mas, também, fantasmas, sentimentos, emoções, aspirações, um certo tipo de relação aos desejos conscientes e inconscientes, à infância, às crenças, à sociedade, à expectativa, à família, ao presente e ao futuro: tudo o que constitui a experiência humana (Gaulejac, 2001b).

No processo de constituição identitária de cada indivíduo, a atuação dos grupos ocorre de forma essencial, na medida em que cada pessoa pertence a diversos grupos e instituições ao longo de sua existência, cada qual possibilitando a inscrição de normas e valores na subjetividade de seus integrantes e contribuindo para a formação de um código cultural. Esses grupos de pertencimento podem ser primário ou secundário, sendo o primário constituído pelo grupo familiar, responsável pelo reconhecimento de filiação, e o secundário, constituído pelos demais grupos aos quais o indivíduo possa vir a pertencer ao longo da vida, contribuindo para seu reconhecimento enquanto cidadão e o pertencimento a uma herança cultural (Carreteiro, 1993). 
Então, o indivíduo se constrói por meio da interação de diversos fatores que permitem uma existência singular, e uma existência social concomitantemente, essa última a partir de elementos da época, da cultura e da classe social à qual faz parte. Nesse conjunto de interações e influências subjetivas e sociais, muitas vezes contraditórias entre si, existe uma margem de manobra, mesmo que limitada, que permite ao sujeito construir respostas, estratégias e projetos (Gaulejac, 2001). A identidade se constrói, então, a partir de múltiplas interações entre o sujeito e o mundo que o cerca, ao longo de sua vida. (Léonetti, 2007a).

O conceito de identidade não está relacionado a algo estático e definido mas, ao contrário, refere-se a um resultado provisório e momentâneo de um processo que é dinâmico e contínuo de subjetivação, que estrutura a posição sociopolítica do indivíduo no tempo e no espaço (Parazelli, 2000). Nesse sentido, a história familiar possui papel crucial de suporte nessa construção, pois se inscreve no corpo e no psiquismo de seus membros, por meio da interiorização da forma de falar, de caminhar, de se vestir, caracterizando o conjunto de atitudes e condutas de cada um. Porém, vale ressaltar que a história individual está inscrita na história familiar, e essa, em uma história sociocultural, cada história com suas características específicas (Ruiz, 2013a).

Léonetti (2007b) pontua que existem duas características importantes da identidade, são elas, necessidade de valorização e necessidade de identificação a um grupo. Cada indivíduo tem a necessidade de ser reconhecido, admirado e aceito pelo outro com vistas à confirmação de sua própria existência. E essa necessidade aparece por meio do sentimento de se possuir características reconhecidas pelo grupo, mas também pela sensação de atuar, de poder influenciar esse grupo.

Mas, em uma sociedade marcada pela hipermodernidade, atravessada pela lógica da competição e da individualização, o reconhecimento social fica atrelado ao lugar que cada um ocupa: o de um trabalhador qualificado, o de um estudante com alto desempenho, o de um 
desempregado, o de um adolescente autor de ato infracional, o de um jovem em acolhimento institucional, sempre passando pelo crivo da produtividade e da excelência. Esse posicionamento social possui um status e diz da identidade social de cada indivíduo, numa luta constante por uma existência social. E, ao invés de uma luta de classes, temos uma luta por lugares, uma luta individual (Gaulejac, 2007b).

Em uma situação de identidade social desvalorizada, o indivíduo sente essa desvalorização, muitas vezes difícil de suportar, e ocorre também uma despersonalização, pelo distanciamento entre como o sujeito se percebe e como é percebido pelo outro, pela sociedade. Esse intervalo entre uma imagem valorizada de si mesmo e a imagem negativa enviada pelo olhar do outro pode provocar um sentimento de vergonha, que toca diretamente a autoestima de cada sujeito e o faz sentir-se responsável por não alcançar o padrão esperado socialmente. Pelo olhar do outro, a vergonha é percebida por meio de um sujeito que não sabe mais o que fazer, que não ousa mais agir. Mas com frequência a vergonha está associada à culpa, essa última relativa ao não cumprimento de regras e normas sociais, o que confere um sentido de irresponsabilidade ao sujeito, tanto a partir do olhar do outro, como pelo próprio olhar sobre si. Então, por meio da culpa, pode haver reações agressivas do sujeito contra ele mesmo, como forma de autopunição (Léonetti, 2007c).

Já a humilhação, também vinculada a uma situação de desqualificação social, decorre de um sentimento de impotência face a uma relação de forças desiguais, mas o sujeito não se percebe enquanto responsável por estar em um local desfavorável. Muitas vezes ela está associada ao ódio e à raiva que se manifesta de forma agressiva contra o outro. Diante de uma identidade desvalorizada socialmente, além da vergonha e da humilhação, pode aparecer também o sentimento de revolta por meio da manifestação contra situações de injustiça. A revolta pode ser identificada por meio de ações sociais individuais ou coletivas, por meio do desejo de revanche, de identificação ao dominante, e também por meio de movimentos sociais 
ou utopias, além de movimentos de contestação destrutivos, fruto de um sentimento de desesperança (Léonetti, 2007c).

Para as pessoas que não alcançaram um reconhecimento positivo, produtivo e de sucesso perante a sociedade, o reconhecimento social muitas vezes ocorre por meio de instituições que trabalham com famílias sem emprego ou sem renda fixa, que vivem em situação de violência intrafamiliar, de abuso infantil, que possuem membros com transtornos mentais, que estão no sistema penitenciário ou em acolhimento institucional, por exemplo. Por meio da elaboração de planos de atendimentos individualizados, de projetos de vida para cada usuário desse tipo de serviço, os profissionais dessas instituições buscam reverter a situação de decadência social para outra de sucesso, de conquistas, de produtividade. Mas essas intervenções ficam no plano individual e, na grande maioria dos casos, não existe um projeto coletivo nesse sentido (Gaulejac, 2007b). E isso pode ser visto no acolhimento institucional de crianças e adolescentes, no qual existe uma orientação para que os profissionais construam um Plano de Atendimento Individual e Familiar (CONANDA \& CNAS, 2009).

Assim, o pertencimento a um grupo visto de forma negativa pelo conjunto da sociedade dificulta a valorização dos seus membros, que muitas vezes sentem-se impotentes, reforçando uma imagem negativa de si mesmo e o sentimento de vergonha atrelado a essa situação. Mais do que um trabalho profissional de forma individualizada, é essencial a revalorização de todo o grupo estigmatizado, buscando um outro lugar social no qual seja reconhecido. Essa não é uma tarefa simples pois, para isso, é necessário um remodelamento do sistema cultural e de valores de nossa sociedade para possibilitar outras formas de reconhecimento que não passem pela excelência (Léonetti, 2007b). 


\subsubsection{Exclusão Social}

O termo exclusão social é utilizado na atualidade por diversos pesquisadores, psicólogos, assistentes sociais, jornalistas, dentre outros, assim como aparece em algumas políticas públicas em prática no Brasil. Porém, esse termo não possui uma definição única e consensual (Sawaia, 2010). Nesse sentido, será apresentado e discutido como tal conceito foi considerado nessa pesquisa.

Robert Castel (1994), fala em marginalização e afirma que esse é um processo e está relacionado ao resultado de um dinâmica da exclusão que se faz presente antes mesmo de seus resultados completamente excludentes. Para o autor, dois eixos precisam ser avaliados em relação à exclusão, quais sejam, trabalho e inserção relacional. A partir da verificação do grau de integração do indivíduo nesses dois eixos, ele indica três zonas relacionadas ao processo de exclusão social: zona de integração (trabalho estável e forte inscrição relacional), zona de vulnerabilidade (trabalho precário e apoio relacional frágil) e zona de marginalidade, que ele prefere chamar de zona de desafiliação (falta de trabalho e isolamento relacional).

Vale salientar que essas três zonas não são estáveis e que suas fronteiras possuem contornos móveis, verificando-se passagens constantes dos indivíduos entre essas zonas. Os que são pobres, mas possuem um emprego fixo e uma forte rede social de apoio, estão na zona de integração. Já na zona de vulnerabilidade estão os que realizam trabalhos temporários, intermitentes, recebendo pouco por suas atividades. Os que compõem a zona de desafiliação não trabalham e, no geral, não possuem apoio relacional. Assim, um trabalho na zona de vulnerabilidade é estratégico para que se fortaleça o que o indivíduo ainda possui, mesmo que frágil, evitando-se assim a entrada na zona de desafiliação. E, estando na zona de desafiliação, é importante um trabalho que evite a instalação de uma situação crônica de marginalização (Castel, 1994). Nesse sentido, a situação de rua, a partir de uma leitura da 
ruptura de laços sociais, testemunharia um complexo e progressivo processo de desafiliação (Bellot, 2000).

Em relação à intervenção profissional junto ao público que se encontra em um processo rumo à desafiliação, pela complexidade dos elementos ali presentes, pelas situações intermediárias e mistas que se apresentam, existe uma dificuldade dos profissionais em classificar quais tipos de ações são necessárias no trabalho com esse público, elementos esses que não são somente de responsabilidade do sistema de saúde, ou da polícia, ou da justiça ou da assistência social. As dificuldades encontradas permeiam vários campos de intervenção simultaneamente e, nesse sentido, Castel (1994) propõe ações globais que busquem elaborar um programa junto a esse público, no sentido de mobilizar habilidades do sujeito para que ele caminhe no sentido da integração e não continue no caminho da exclusão. Intervenções preventivas e reparadoras não são, nesse contexto dinâmico, antagonistas, mas complementares entre si.

Outra questão importante é em relação à divisão de responsabilidades, pois não é somente o indivíduo que deve oferecer uma contrapartida à prestação de serviço que ele recebe, mas a coletividade também precisa se organizar para propor ações de inserção adaptadas à situação do indivíduo, ações realizáveis por ele. Porém, inserir não significa necessariamente integrar, considerando que o trabalho de (re)inserção social, muitas vezes, não culmina necessariamente em um emprego estável nem na participação de uma rede de apoio relacional forte e estável, critérios esses estabelecidos por Castel (1994) para a integração. O termo (re)inserção está aqui pontuado dessa forma, pois acrescenta-se à discussão de Castel a situação de muitos indivíduos que possuem uma trajetória de vida marcada, de forma transgeracional, pela falta de um emprego estável entre os membros de sua família, quando criança e adolescente, e pela falta do próprio emprego estável quando adulto. Da mesma forma, existem famílias que há gerações são marcadas pela falta de relações sociais estáveis. 
Em outras palavras, o processo seria mais próximo da inserção social do que da reinserção propriamente dita.

A discussão de Castel (1994) sobre o processo de exclusão social indica aspectos em relação ao acolhimento institucional de adolescentes. A partir dos dois critérios por ele indicado, emprego e apoio relacional, pode-se apontar que a necessidade de acolhimento institucional por si só indica uma fragilidade na rede de apoio relacional, tendo em vista que não foi possível para a menina acolhida ou para o menino acolhido sua permanência na família de origem, nem seu acolhimento na família extensa ou de pessoas mais próximas. Os que são acolhidos depois de terem morado na rua também se encaixam nessa situação. Em relação ao emprego, esse ponto não será considerado pois ele seria um fator a ser trabalhado no processo de reintegração do adolescente, na forma permitida por lei. Segundo o Estatuto da Criança e do Adolescente (1990), é permitido ao adolescente trabalhar segundo idade e condições específicas. A falta de emprego do adolescente não resulta no acolhimento institucional.

Assim, uma medida protetiva que visa o acolhimento do adolescente, indica, ao mesmo tempo, que ele se encontra na zona de vulnerabilidade, lugar com grandes possibilidades de intervenção com vistas à sua reinserção familiar, mas indica também, de forma concreta, sua entrada num processo de exclusão social ou, como denominou Castel (1994), em um processo de desafiliação social. Não que antes o adolescente não se percebesse nesse processo, mas agora esse é mais visível tanto para ele, quanto para a sociedade. É a indicação de que os vínculos familiares estão frágeis. Em outras palavras, uma ação positiva, no caso, a medida protetiva de acolhimento institucional, carrega também, uma conotação negativa para o indivíduo que a recebe, mostrando-lhe de forma clara seu posicionamento na sociedade que passa a ser, então, aos olhos do outro, um adolescente abrigado. Isso repercute na subjetividade desse adolescente pois, conforme acrescentou Léonetti (2007a), é 
imprescindível que na análise do processo de exclusão social, a interface sociedade e subjetividade seja considerada, com suas possíveis repercussões. E é essa articulação que será privilegiada na presente pesquisa, considerando então, não somente a organização social ou as reações dos indivíduos, mas a interdependência entre essas duas instâncias.

Para Léonetti (2007a), o polo oposto ao da exclusão é o da integração e, entre esses dois extremos, os indivíduos podem transitar e ocupar vários lugares, ao longo da vida. Três dimensões principais dizem sobre o lugar social de cada um: dimensão econômica, dimensão social e dimensão simbólica. A primeira dimensão geralmente é utilizada de forma quantitativa, indicando a soma de recursos financeiros recebidos e as formas de consumo de uma família, tais como renda, tipo de moradia, aparelhos elétricos e eletrônicos de uma família, que vão indicar qual o nível de vida daquele grupo familiar.

No Brasil, por exemplo, o Instituto Brasileiro de Geografia e Estatística - IBGE, classifica a população em classes sociais, a partir da renda mensal de cada família, sendo: classe social A: renda de mais de 15 salários mínimos; classe social B: renda que varia de cinco a 15 salários mínimos; classe social C: renda de três e cinco salários mínimos; classe social D: renda mensal de um a três salários mínimos e classe social E com renda de até um salário mínimo (www.ibge.gov.br). Há também o Critério de Classificação Econômica Brasil, da Associação Brasileira de Empresas de Pesquisa, não classifica as pessoas e as famílias por classe social, mas por classe econômica, tendo em vista que seu objetivo é estimar o poder de compra da população para orientar a produção de bens e serviços a serem ofertados por região do país. Esse critério considera a presença de alguns eletrodomésticos e eletrônicos, trabalhadora doméstica mensalista na casa, grau de instrução do responsável e renda média familiar (ABEP, 2014).

Mas é importante relativizar a questão da pobreza, muitas vezes vista de forma quantitativa, pois esse conceito também diz da incapacidade de uma pessoa em satisfazer suas 
necessidades de consumo, valorizadas em dada sociedade. E sobre o que é valorizado, existe um modelo dominante que se impõe e influencia a necessidade dos sujeitos, mesmo que haja diferentes formas de consumo no interior de uma mesma sociedade. Então, a questão da pobreza está relacionada também a uma questão normativa, que orienta os desejos e comportamentos das pessoas. Consumir menos ou consumir de forma diferente é visto como uma situação anormal, relacionada à incapacidade pessoal de satisfazer as necessidades padrão de uma certa sociedade. Ser pobre ou sentir-se pobre está, assim, relacionado com o não consumo do que é valorizado pela sociedade como um todo (Léonetti, 2007a).

Sobre a dimensão social, Léonetti (2007a) aponta para uma fragilização das relações sociais e que, para além de diminuição de ajuda mútua e apoio em caso de difículdade, influencia também um processo de ruptura de pertencimentos. Com a fragilização de uma identidade coletiva, o grupo deixa de ser referência e fonte de valorização/reconhecimento dos sujeitos. E sobre a dimensão simbólica, essa está relacionada ao sistema de normas e às representações coletivas. Cada conduta social se orienta por normas e códigos que lhes atribuem um valor perante a sociedade. Certos modos de vida e de consumo vão se impondo aos indivíduos como um ideal de si mesmo social, passando pela questão do reconhecimento e valorização coletiva. O não enquadramento de alguém a esse ideal pode levar à sua desvalorização e rejeição por parte da sociedade. A exclusão social propriamente dita, como um dos extremos do processo de desinserção, não é tão comum em nossa sociedade, pois algum tipo de relação com o social é preservado, mesmo em situações graves onde esses vínculos ficam mais tênues.

Como exemplo de fragilização dos vínculos sociais, Carreteiro (1994) apresenta a situação de famílias do Rio de Janeiro que moram em favelas, onde é comum a dificuldade de muitos encontrarem um trabalho estável ou ter um local de moradia fixo. A criação de favelas ou as ocupações irregulares de espaços públicos indicam uma vida com características nômades, 
tendo em vista que essas famílias são constantemente removidas de suas habitações por agentes de fiscalização do Estado. Essas constantes mudanças, a formação e o posterior desmembramento e dispersão desses grupos indicam uma característica desses coletivos e falam de sua existência social. Observa-se uma dificuldade em se referirem como um grupo, com uma história comum. Há também a preocupação com o momento presente, com a sobrevivência, impossibilitando que construam a própria história, um projeto de futuro. $\mathrm{E}$ ao esquecer, ou não considerar a própria história, corre-se o risco de se repetir as mesmas condutas, nem sempre saudáveis. Uma das opções apontada por Carreteiro (1994), nesse caso, é o de criar espaços de convivência que podem fortalecer as relações entre os membros do grupo, favorecendo que compreendam sua história e o significado de seu lugar de moradia. Após essa etapa, será mais fácil que organizem ações coletivas no intuito de melhorar suas condições objetivas e subjetivas de vida.

A partir das colocações de Carreteiro (1994), pode-se fazer um paralelo com o acolhimento institucional de adolescentes. Eles são colocados para morar num local onde, geralmente, não conhecem os demais acolhidos e os que trabalham na instituição, não compartilhando então a mesma história. Mas, se os profissionais criarem espaços de convivência entre os acolhidos, além de possibilitar que adquiram maior compreensão de sua situação de acolhido, aproxima os adolescentes entre si e possibilita a construção de projetos de vida de acordo com as circunstâncias de cada um. Essa construção conjunta, sendo compreendida e reconhecida pelo grupo, aumenta as possibilidades da concretização do que foi construído. Em outras palavras, uma forma de se trabalhar numa instituição de acolhimento é por meio de atividades em grupo e não ficar restrito a atendimentos individualizados, mesmo que as histórias sejam diferentes. Como reforçou Carreteiro (1994), agir junto, reconhecendo a diversidade e pluralidade dos atores envolvidos, é um sinal de reconhecimento. 
A proposta de Carreteiro mostra-se em sintonia com a colocação de Guareschi (2010), pois esse autor considera que, se todo ser humano é constituído em relação a outras pessoas em variados contextos, e se todo grupo humano também se organiza e se estabelece a partir das relações que os diferentes indivíduos estabelecem entre si, o que modifica um grupo não é a mudança das pessoas que o compõem, mas a mudança nas relações que essas pessoas estabelecem entre si. Então, por meio do trabalho em um grupo, podem-se promover transformações nesse grupo e, por consequência, nas pessoas que os compõem.

Em nossa sociedade atual, hipermoderna e individualista, na qual os suportes de socialização ficam fragilizados, o grupo, que tem papel fundamental de defender seus membros de um olhar social muitas vezes estigmatizante, ao produzir contra-modelos e outras normas em relação ao modelo dominante, vai perdendo sua força. E não se trata de uma situação, mas de um processo que leva muitos indivíduos, e famílias, ao que Léonetti (2007b) chama de desinserção social, na qual os sujeitos são isolados socialmente e invalidados psicologicamente. As redes de solidariedade são cada vez mais complexas e diversificadas, mas ao mesmo tempo, mais frágeis e menos vitais para os indivíduos. Mais do que uma ruptura das relações sociais, vemos uma constante composição e recomposição dessas redes de apoio, com uma fragilização do pertencimento a esses grupos.

Uma situação que se evidencia nesse contexto é a atuação do Estado, no sentido de fortalecer e manter a coesão social mínima entre a população. O então Estado-providência assume um papel de mediador dos conflitos sociais, assegurando uma redistribuição dos bens coletivos para que um grupo do conjunto social não fique deixado à própria sorte (Léonetti, 2007d). No Brasil, a Política Nacional de Assistência Social se insere no tripé do bem-estar social, enquanto Seguridade Social, junto das políticas de Saúde e Previdência Social, e busca garantir direitos e condições dignas de vida para toda a população. Assim, "a assistência social configura-se como possibilidade de reconhecimento público da legitimidade 
das demandas de seus usuários e espaço de ampliação de seu protagonismo" (PNAS, 2004, p. $32)$.

Mas, de forma paradoxal, ao reconhecer as demandas das famílias, as políticas sociais estigmatizam e marginalizam seus usuários, na medida em que colocam em evidência que eles estão fora do sistema produtivo daquela sociedade. E se de um lado tem-se os que julgam essas ações como um reforço à passividade dos indivíduos, e uma carga pesada para toda a coletividade, de outro, existem os que percebem essas ações como insuficientes. E o Estado não consegue criar uma união entre os usuários da assistência e os demais com vistas a um projeto social comum, entre os que sentem vergonha e humilhação por serem usuários da assistência e os que sentem desprezo, pena ou medo desses sujeitos (Léonetti, 2007b).

\subsubsection{Desinserção social}

O termo desinserção social faz referência a um processo dinâmico que articula tanto elementos concretos da existência, que determinam trajetórias de vida, quanto relações subjetivas a essas condições que podem mudar uma trajetória ou reforçar a permanência em uma engrenagem da qual se faz parte. Blondel (2007) indica as principais etapas de uma trajetória que pode levar à exclusão social, a partir de B. Bergier. A primeira etapa é a da ruptura, que pode ocorrer por meio do desemprego, do abandono ou de uma morte repentina na família, por exemplo, situação essa que o indivíduo não consegue administrar e que pode provocar uma instabilidade emocional. Ele precisa lidar com essa situação estando no mesmo meio que antes, tendo que mudar de atitude. Essa tensão pode ser expressa por meio da raiva e da calma de forma alternada, podendo levar o indivíduo a diminuir sua autoestima.

Uma segunda etapa se relaciona com um encadeamento de rupturas, relacionado à forma de gestão da primeira ruptura e que pode favorecer que o sujeito se torne frágil a outras rupturas. Como terceira etapa, ocorre um afastamento maior de sua situação anterior, onde o 
indivíduo passa a se utilizar de recursos institucionais especializados para se alimentar, se abrigar ou receber ajuda financeira, por exemplo. Esse é um momento crucial para o indivíduo, pois vai marcar uma mudança de sua identidade social, na qual passará a ser reconhecido pela sua falha (Blondel, 2007). Sobre a quarta etapa, temos o declínio social e a entrada do indivíduo em um grupo de excluídos, marcando seu novo pertencimento social. Há o aprendizado de um novo tipo de conhecimento que permite ao indivíduo viver com o mínimo de dificuldade possível e fazer parte da subcultura de determinado grupo que não é reconhecido nem valorizado socialmente. Com essa trajetória, o indivíduo vai deixando de se questionar e acredita que aquela é a única forma de vida possível para ele (Blondel, 2007).

Mas ocorre que essas etapas não consideram a dinâmica psicológica dos sujeitos nesse processo, como se todo processo de exclusão fosse um caminho linear e sem volta. Blondel (2007) então, acrescenta a essa discussão uma outra visão, pois, para ele, esse processo ocorre em meio a tensões entre como o indivíduo se percebe em dada situação e como é percebido pelo outro. $\mathrm{O}$ autor reforça que esse indivíduo não aceita o olhar que recai sobre ele de forma instantânea e passiva, apontando três fases de reações possíveis face a um processo de desinserção: fase da resistência, fase de adaptação e fase da instalação, dependendo do momento e de cada indivíduo. Essas três fases podem ser identificadas em cada etapa do processo de desinserção social (Blondel, 2007).

$\mathrm{Na}$ fase da resistência, o indivíduo vai se utilizar de recursos afetivos, sociais e culturais para resistir à entrada a uma nova situação social para a qual é conduzido, situação essa percebida como pior que a situação anterior, como no caso da perda de um emprego. Os que viveram uma história familiar de referências afetivas estáveis resistem melhor aos novos eventos difíceis que encontram. Assim, as origens cultural e social atuam de forma importante na percepção e resistência do indivíduo a bloquear seu ingresso no processo de desinserção. Mas um dos sentimentos que pode aparecer é o da vergonha social, em decorrência do olhar 
do outro face a sua nova situação, percebida por esse outro como um fracasso pessoal. Há uma busca, então, de alternativas para tentar controlar os efeitos de insegurança que a nova situação suscita no sujeito (Blondel, 2007).

Já na fase da adaptação, o indivíduo, que não conseguiu sair de sua nova situação de declínio, busca retornar para seu status anterior, organizando então um novo modo de vida. A fim de diminuir seu sofrimento, se adapta psicologicamente às novas condições de existência, pois não consegue mudar as condições que lhe oferecem uma imagem negativa de si mesmo. Não pertence mais ao seu grupo de origem e passa a agir conforme seu novo grupo, ao mesmo tempo em que tenta evitar esse novo pertencimento social. Na terceira e última fase, ocorre sua submissão à nova situação, com a passividade do sujeito que não se vê em outra situação que não seja aquela. De forma geral, para cada uma das quatro etapas do processo de desinserção social, podem ocorrer essas três fases de reação do indivíduo, o que nos permite uma leitura que engloba tanto condições concretas e objetivas de vida, quanto sua relação com a subjetividade de cada um (Blondel, 2007).

Mas, apesar das dificuldades, os indivíduos possuem uma margem de liberdade e criam estratégias de resposta diante das situações difíceis vivenciadas. Essas estratégias são comportamentos, individuais ou coletivos, que, após avaliação de certa situação de interação social, buscam alcançar alguma finalidade. Assim, as estratégias nos mostram como os comportamentos são o resultado de uma interação entre elementos sociais e psicológicos, pois, uma situação social de exploração ou desigualdade social, que são fenômenos sociais abstratos, são percebidos pelos indivíduos por meio de sentimentos de frustração ou humilhação, por exemplo. E esses fenômenos psicológicos vão induzir comportamentos de respostas sociais desses indivíduos face à situação vivenciada. Essa dinâmica pode ser identificada por meio dos sentimentos dos indivíduos, pois eles nos mostram como uma situação social agiu sobre um sujeito, como ela foi percebida e sentida e, também, como esse 
sujeito atuou nesse contexto por meio de uma resposta estratégica, com vistas a alcançar certa finalidade (Léonetti, 2007c).

Assim, como possíveis estratégias de respostas, diante de situações que causam sofrimento, Léonetti (2007c) indica três tipos. A primeira estratégia é a de evitação, na qual o indivíduo contesta e resiste à interiorização de uma imagem negativa de si mesmo, a partir do olhar do outro que o estigmatiza. Na dimensão psicológica, podem ser identificadas uma distanciamento e uma inversão de sentido face à nova situação vivenciada. Na dimensão social, essa estratégia aparece por meio da inserção em grupos marginalizados e em uma não implicação no sistema de normas e valores dominantes. Por exemplo, uma pessoa que está no tráfico de drogas pode perceber sua situação como sinônimo de coragem, força e liberdade.

Sobre a segunda estratégia, o indivíduo busca revalorizar sua própria identidade, agindo sobre as condições sociais que originaram seu sofrimento. Busca um trabalho ou uma moradia, por exemplo, ações valorizadas socialmente e que podem ajudá-lo a encontrar ou reencontrar um status social reconhecido positivamente pela sociedade. Já em relação ao terceiro grupo de resposta, o sujeito interioriza uma imagem negativa de si mesmo por meio de estratégias de defesa, buscando meios de suportar, mascarar ou esquecer seu próprio sofrimento. Na dimensão psicológica, tem-se como exemplo a submissão ou o jogo de papéis sociais, enquanto que na dimensão social aparecem, dentre outros, o isolamento, a fuga da realidade por meio do consumo de drogas e a passividade social (Léonetti, 2007c).

Então, em relação ao processo de desinserção social pode-se identificar tanto elementos da realidade concreta, social e coletiva que atuam no sentido de favorecer que ele ocorra, como também elementos da subjetividade dos sujeitos e dos grupos face a essa situação. Nesse contexto, a intervenção dos profissionais nessas situações precisa incluir tanto ações de cunho material, buscando resolver problemas concretos relacionados à moradia, acesso das crianças à escola e inserção no mercado de trabalho, por exemplo, bem como ações que 
trabalhem a dimensão psíquica desses indivíduos, com os significados e sentimentos envolvidos (Léonetti, 2007c).

Mas, considerando que a intervenção institucional é um outro elemento que também entra em cena, paradoxalmente, sentimentos de culpa e de humilhação podem ser estimulados pela inserção de indivíduos em um serviço público de assistência social. Esse ponto não pode ser ignorado e, pelo contrário, deve integrar a análise profissional de um processo individual, familiar ou grupal de desinserção social (Léonetti, 2007c).

\subsection{Medida Protetiva de Acolhimento Institucional}

Esse tópico possui como objetivo estabelecer uma relação entre o Serviço de Acolhimento Institucional para crianças e adolescentes no Brasil e as histórias de adolescentes que são atendidos por esse serviço. Busca-se compreender de que forma a história institucional do serviço de acolhimento repercute nas histórias individuais de adolescentes acolhidos. Considera-se ainda que as experiências e trajetórias de vida de adolescentes acolhidos também interferem na história das instituições.

A reflexão aqui apresentada considerou a realidade do contexto brasileiro, tendo em vista que o Brasil, conforme Takeuti (2009), vem passando por um processo de redemocratização, ainda com contradições, ambiguidades e insuficiências, mas que amplia espaços de participação social dos indivíduos. Por outro lado, o longo processo de silenciamento de um grande contingente populacional desfavorecido economicamente, ainda repercute na atualidade, dificultando que assumam um lugar social onde tenham voz e acesso a direitos garantidos constitucionalmente.

Especificamente no caso do serviço de acolhimento de crianças e adolescentes, esse apresenta em sua história, momentos nos quais os acolhidos não eram vistos como sujeitos de direitos, mas como meninos e meninas que precisavam ficar apartados da sociedade. É, então, 
necessário que se compreenda se a atual configuração do serviço no país consegue abarcar o que está previsto no Estatuto da Criança e do Adolescente (1990) e no documento elaborado pelo Conselho Nacional dos Direitos da Criança e do Adolescente (CONANDA) e Conselho Nacional de Assistência Social (CNAS) (2009), denominado Orientações Técnicas: Serviços de Acolhimento para Crianças e Adolescentes. Rossetti-Ferreira et al. (2012) constataram a "necessidade de um mergulho na história dessas instituições e, ao mesmo tempo, na observação de suas atuais formas de organização e funcionamento" (p. 391), pois, como bem apontou Arpini (2003), a alteração da legislação que trata do acolhimento de crianças e adolescentes no Brasil não garante, necessariamente, que alguns abusos e violências de tempos atrás não se reproduzam no novo modelo.

\subsubsection{Serviço de acolhimento de crianças e adolescentes}

Uma breve retomada da conquista do reconhecimento dos direitos de crianças e adolescentes no país aponta primeiramente a Constituição da República Federativa do Brasil (1988), que baliza os demais dispositivos jurídicos, e que já passou por 74 Emendas Constitucionais para melhor atender aos interesses da população. No ano de 1990, foi instituído o Estatuto da Criança e do Adolescente - ECA (1990), sendo alterado pela Lei Federal 12.010 (2009) em alguns pontos.

Com o advento do ECA (1990), as violações de direitos contra crianças e adolescentes passam a ser reconhecidas pelo Estado, que promove, por sua vez, ações de proteção em favor deles e responsabilização dos que cometem violações. Nos casos extremos onde as crianças e os adolescentes são vítimas dessas violações, uma medida protetiva que pode ser aplicada é o acolhimento institucional, até que cesse o risco e a criança e/ou adolescente possa ser reintegrado(a) à sua família de origem ou em família substituta. Esse acolhimento institucional de crianças e adolescentes de zero a 17 anos e 11 meses faz parte da Proteção 
Social Especial de Alta Complexidade, da Política Nacional de Assistência Social - PNAS (2004) e tem por objetivo garantir proteção integral aos acolhidos, o que inclui moradia, alimentação, vestuário e higienização no tempo em que estiverem fora do contexto familiar. Vale ressaltar que essa proteção social precisa garantir o convívio familiar e/ou social dos acolhidos, proporcionando contato familiar, quando possível e inclusão nos dispositivos da comunidade, tais como escola, serviço de saúde, centro esportivo, dentre outros.

Nesse contexto, o Plano Nacional de Convivência Familiar e Comunitária (2006) reforça a importância da manutenção dos vínculos familiares e comunitários das crianças e adolescentes, reconhecendo a importância da mobilização de outras políticas de Estado e da sociedade civil para o alcance desse objetivo. Também indica que o acolhimento institucional pode ser organizado, entre outros, nas modalidades abrigo institucional para pequenos grupos ou casa lar, que são as modalidades abordadas na presente pesquisa. Os parâmetros de funcionamento, que inclui público-alvo, aspectos físicos, recursos humanos e infraestrutura dessas modalidades são discutidas detalhadamente do documento Orientações Técnicas: Serviços de Acolhimento para Crianças e Adolescentes (CONANDA \& CNAS, 2009).

As instituições de acolhimento podem ser de natureza pública-estatais ou não-estatais, sendo que os abrigos institucionais podem receber até 20 acolhidos, e as casas lares, até 10 crianças e adolescentes, sempre inseridos em meio residencial (CONANDA \& CNAS, 2009). A medida protetiva de acolhimento institucional é aplicada pelo Juiz da Infância e da Juventude, muitas vezes por meio da atuação do Conselho Tutelar, pois se entende que, temporariamente, a família não se encontra em condições de proteger e cuidar daquela criança e/ou adolescente. Durante o tempo do acolhimento, psicólogos e assistentes sociais do abrigo ou casa lar trabalham no sentido de promover a reintegração familiar e/ou comunitária dos acolhidos no menor tempo possível. 
Em termos legais, a medida protetiva de acolhimento institucional está prevista no Art. 101, VII do ECA (2009). Sua aplicação ocorre pela presença de situações de violação de direitos, como maus tratos, negligência ou abuso sexual, por exemplo, no ambiente familiar. Pode ocorrer também da situação de violência ocorrer fora do contexto da família, e esta, por diversos motivos, não conseguir proteger a criança ou o adolescente dessas vivências. Vale ressaltar que o acolhimento é provisório e excepcional, mas em alguns casos, a reintegração na família de origem ou em família substituta não ocorre, sendo então, extremamente necessário, um trabalho junto ao adolescente, de promoção de sua autonomia para a vida adulta.

Sobre a dinâmica familiar das crianças e dos adolescentes acolhidos, Siqueira (2006) indica que, em muitos casos, existe a presença de características como baixa coesão entre seus membros, desequilíbrio de poder e fatores de risco numerosos e expressivos em relação aos fatores de proteção. Assim, o trabalho da equipe de especialistas da unidade de acolhimento institucional é essencial para que tais questões possam ser revistas e ressignificadas no grupo familiar, fortalecendo-a em sua função protetiva. Porém, é preciso que os profissionais fiquem atentos para não culpabilizarem as famílias e sempre considerarem a história das mesmas e o contexto social no qual estão inseridas. Considerando que uma das funções da família é a socialização, na qual a criança descobre formas de se relacionar com os outros, o que é permitido ou não e o que se espera dela, Ruiz (2013a) reforça e ideia de que todo esse processo está diretamente vinculado ao meio social e cultural onde a família se encontra.

Assim, ao se trabalhar com famílias, visando reforçar sua função protetiva para reintegrar a criança ou o adolescente que está em acolhimento institucional, é imprescindível que os profissionais considerem os aspectos sociológicos do contexto familiar, pois esses atuam nos aspectos psicológicos de seus membros, tais como o pertencimento a determinada classe social, a uma certa cultura ou religião. Esses elementos vão influenciar as formas de se 
perceber a família, os limites, como se devem estabelecê-los, as regras e a concepção de proteção das crianças e dos adolescentes. Vale salientar que uma organização familiar, com suas formas de respostas a situações concretas e que indicam ao indivíduo formas de ser e de comportar-se em situações sociais, é transmitida de geração em geração (Ruiz, 2013a).

Focalizando a análise no acolhimento de adolescentes, além da família com vínculos fragilizados e da violação de direitos ao qual esses meninos e meninas vivenciam, eles são inseridos em uma instituição desconhecida, sendo levados a conviverem com crianças e outros adolescentes também acolhidos e com adultos que estão ali para os receberem e proporcionarem um desenvolvimento mais saudável possível. Muitas vezes a instituição de acolhimento apresenta regras de convivência as quais nem sempre o adolescente conhece ou faz parte do seu cotidiano, sendo necessário, mesmo assim, segui-las desde o início do acolhimento. Tal situação pode gerar angústia e insegurança a esses adolescentes.

\subsubsection{A adolescência em acolhimento institucional}

Ressalta-se que o conceito de adolescência, tal qual se conhece hoje, nem sempre teve essa conotação e, muito menos, o aspecto legal que possui atualmente. A palavra adolescência vem do latim, especificamente do verbo adolescere, cujo significado é crescer para a maturidade (Mussen, Conger, Kagan \& Huston, 2001). Antes do século XX, as crianças passavam diretamente para a fase adulta assim que ingressassem no mundo do trabalho. Porém, com a Revolução Industrial que ocorreu no final do século XIX, o trabalho especializado e consequentemente os estudos, passaram a ser importantes, surgindo a escolarização obrigatória até os 16 anos de idade para, posteriormente, entrarem no mercado de trabalho com a qualificação necessária (Coll, Marquesi \& Palácios, 2004). Esse intervalo de tempo dedicado a um estudo especializado, antes do ingresso no mundo do trabalho, passou a ser conhecido como o período da adolescência. Assim, como a adolescência é uma 
construção social, referente à passagem da infância ao mundo adulto, é importante que se considere, numa pesquisa que trabalhe com esse público, que ele varia segundo o momento histórico e segundo a sociedade à qual faz parte (Parazelli, 2002).

Para a compreensão do conceito de adolescência pela perspectiva da Psicossociologia, é importante relembrar o conceito de identidade, pontuado por Gaulejac $(2005,2006)$, em que o indivíduo não para de se transformar ao longo da vida. Estão presentes nesse processo de construção identitária do adolescente, sinais particulares que os distinguem de outros indivíduos e, ao mesmo tempo, características comuns a todos aqueles que são como ele. É um processo contraditório, pois está presente a necessidade de diferenciação e de identificação ao outro, que são opostas e complementares. A identificação é um processo psicossocial, em que elementos que estavam no exterior são internalizados, compondo sua identidade. Mas, ao mesmo tempo em que ocorre a interiorização de certos aspectos por meio da identificação, é importante que o sujeito se diferencie desse outro, buscando organizar elementos que mostrem sua diferença e singularidade perante os demais. Então, nessa relação complexa entre aspectos semelhantes e diferentes do outro, a identidade vai se constituindo, ou seja, vai se organizando com elementos comuns e distintos de outras pessoas. Gaulejac (2006) acrescenta que, dentre os elementos que são internalizados, estão presentes elementos dos contextos social, cultural e ambiental, que são percebidos e sentidos pelo sujeito de forma singular.

Nesse contexto, a adolescência é parte desse processo maior de construção de identidade, em uma preparação para a vida adulta. Porém, a adolescência é advinda da puberdade, sendo esse o período em que caracteres sexuais secundários aparecem e em que ocorre o estirão puberal. Tem-se, com isso, importante impacto da alteração hormonal e física nas emoções, na forma como o adolescente se percebe e como percebe os outros (Silva \& Adan, 2003). Considerando que o contexto onde o adolescente está interfere na construção de 
sua identidade, é importante que se conheça o contexto do acolhimento institucional que recebe esses meninos e meninas, para se compreender possíveis repercussões nas histórias de vida desses adolescentes. Assim, é importante que os profissionais que atuam em instituições de acolhimento tenham clareza de que podem ser modelos tanto de identificação quanto de diferenciação dos adolescentes acolhidos, contribuindo no processo de construção de identidade deles. Como os acolhidos não estão em convivência familiar, outras pessoas que fazem parte do seu contexto influenciam nesse processo.

Assim, meninos e meninas acolhidos podem reproduzir alguns comportamentos dos profissionais da instituição de acolhimento, ou agir exatamente de maneira inversa a eles. Atitudes como, imposição de regras da instituição sem escuta dos argumentos do adolescente, não consideração pelos sentimentos do outro e o hábito de sempre falar em voz alta podem ser reproduzidas pelos adolescentes acolhidos com a tentativa de imposição de sua vontade, muitas vezes por meio do grito, o não respeito da regra institucional e a dificuldade em considerar o sentimento do outro, mesmo que seja o de outro acolhido.

No entanto, por mais que os profissionais realizem grupos de diálogos para resolução dos conflitos no coletivo, respeitem a história de cada um e o momento de cada acolhido, vão ocorrer situações em que o adolescente vai agir de forma totalmente contrária ao esperado, afrontando os profissionais e outros acolhidos, muitas vezes por meio da violência. Como indicado anteriormente, no processo de construção de identidade, o adolescente pode, para se diferenciar do grupo e do outro, adotar atitudes contrárias às da maioria. Em outras palavras, não há como prever como será o comportamento do adolescente em uma instituição de acolhimento, mas é importante que sejam oferecidos aos profissionais meios de compreenderem esse processo de construção de identidade e o peso que suas atitudes alcançam nesse contexto. 
Um aspecto importante e que impacta diretamente no acolhimento é a imposição da medida protetiva ao acolhido. Essa medida é aplicada pelo juiz da infância e da adolescência, sempre buscando proteger o adolescente, mas nem sempre ela é bem recebida pelo menino ou pela menina, dificultando principalmente as primeiras intervenções dos profissionais das instituições. Para se fazer uma correlação, foi realizada uma pesquisa na cidade de Montreal, Canadá (Roy et al., 2000), com oito unidades de acolhimento não governamentais. Essas instituições acolhem meninos e meninas de 8 a 14 anos após consentimento deles e de seus responsáveis, respeitando a vontade do então acolhido e de sua família em relação à institucionalização que é temporária. Essa escolha facilitava a criação e o desenvolvimento de um plano individualizado de intervenção, que se orientava no sentido de preparar o adolescentes para uma vida mais autônoma, por meio do estudo e do trabalho, e/ou no sentido de facilitar seu retorno à sua família. As instituições pesquisadas não acolhiam meninos e meninas autores de ato infracional ou em situação de rua, ficando esse público a cargo das unidades estatais. Esses últimos são encaminhados pelo judiciário mesmo que contra a vontade dos jovens e de sua família. Mas mesmo com um público mais específico, as instituições não estatais possuíam papel importante e complementar em relação às estatais.

Viu-se então que a aceitação do menino e da menina quanto ao próprio acolhimento faz diferença quanto à sua implicação do processo de reintegração familiar e/ou comunitária. No caso do acolhimento institucional no Brasil, diferente da pesquisa apresentada acima, a medida protetiva de acolhimento somente é aplicada por juiz competente, mesmo quando essa ação ocorre em unidades não governamentais. Inclusive nos casos em que há aceitação da família e do adolescente quanto ao acolhimento, é necessário haver notificação ao sistema judiciário. Então, indica-se que a aceitação ou não do adolescente quanto ao próprio acolhimento vai atuar de forma importante durante seu processo de institucionalização. Além dessa questão, existem outros elementos que estão presentes nesse processo e que influenciam 
tanto as histórias de vida dos acolhidos quanto as trajetórias profissionais da equipe. Elementos esses, nem sempre tão recentes e que, muitas vezes, legalmente, foram substituídos por outros, mas que ainda permanecem no cotidiano das unidades de acolhimento. Por exemplo, nem sempre os estabelecimentos distinguiam crianças e adolescentes vítimas de violência dos adolescentes autores de ato infracional, tratando-os todos da mesma maneira em um mesmo local. Antes era mais importante a repressão e a punição do que o diálogo e ações de cunho educativo.

Hoje a legislação mudou, assim como a concepção de criança e adolescente, já que eles são vistos atualmente como sujeitos em condição peculiar de desenvolvimento e que precisam de proteção e cuidado, conforme preconiza o Estatuto da Criança e do Adolescente (1990). E quando o profissional conhece a história do acolhimento institucional, ele pode, com mais clareza, avaliar se sua atuação está conforme as normativas atuais ou se ainda reproduz um modelo antigo de institucionalização de crianças e adolescentes. Para um gestor do serviço de acolhimento, essa clareza pode favorecer que ele promova ações junto aos profissionais daquela instituição, no sentido de aprimorar habilidades para o cuidado de crianças e adolescentes em acolhimento, conforme diretrizes da atualidade.

\subsubsection{História do acolhimento institucional e repercussões para o adolescente}

Os elementos apresentados a seguir indicam aspectos da história do acolhimento institucional de crianças e adolescentes que podem influenciar as vidas desses acolhidos. Pois, como afirmou Carreteiro, “... a perspectiva social tem uma forte influência na construção do humano, e as modalidades de práticas sociais são incorporadas ao sujeito" (Carreteiro, 2012, p. 36).

Muitas mudanças ocorreram quanto à organização do acolhimento institucional no Brasil. Um dos pontos importantes da Lei 12.010 (2009) que trouxe mudança para a vida dos 
acolhidos, diz respeito ao tempo máximo de acolhimento institucional. A referida legislação indica dois anos para o tempo máximo de acolhimento de crianças e adolescentes em instituições de acolhimento, salvo em situações em que a reintegração não é possível de ser realizada nesse espaço de tempo. A equipe profissional da unidade de acolhimento deve, então, realizar avaliação da situação da criança e do acolhido a cada seis meses, enviando relatório ao poder judiciário. Mas a realidade mostra que esses acolhidos permanecem em frustração renovada, pois em geral não há cumprimento de prazos, tanto no envio de relatórios quanto na resposta do poder judiciário.

Ocorre que, antes de 2009 não se estipulava esse tempo máximo, por mais que o ECA já apontasse que o acolhimento deveria ocorrer de forma excepcional e temporária (1990). Como reflexo desse contexto social mais amplo, tem-se meninos e meninas que foram acolhidos quando crianças e permanecem ainda hoje em acolhimento ou casas lares, já se aproximando da fase adulta. O tempo de acolhimento repercute no favorecimento ou não da formação de vínculos e influencia em situações futuras de adaptação a outros ambientes, determinando ansiedade, frustração ou temor em relação a essa adaptação.

A institucionalização prolongada leva, como uma de suas consequências, ao maior afastamento entre os acolhidos e suas famílias. Vínculos familiares frágeis se rompem durante esses anos, distanciando ainda mais essas pessoas entre si. Hoje, por mais que se tenha a orientação da permanência máxima por dois anos em uma instituição, existem adolescentes acolhidos, sem contato familiar ou sem possibilidade de reintegração nesse grupo, oriundos do tempo em que nem todas as instituições de acolhimento tinham essa prática.

De qualquer forma, durante o acolhimento, muitas crianças e adolescentes passam por maior fragilização dos vínculos familiares (Rossetti-Ferreira et al., 2012). Nem sempre as ações das equipes profissionais alcançam manutenção ou reconstrução dos vínculos afetivos familiares. Em estudo realizado por Fávero et al. (2008), verificou-se não somente o esforço 
de famílias com filhos em situação de acolhimento institucional no sentido de organizar outras condições de vida para terem seus filhos de volta, mas também a impotência e o sofrimento diante de dificuldades de ordem material para a concretização dessa mudança. A cobrança de uma reorganização familiar centra-se na própria família, o que se mostra como um enfoque perverso do sistema. Em muitos casos, um trabalho articulado em rede junto a esse grupo, buscando o acesso a direitos sociais, não é realizado.

Em investigação sobre configurações sociofamiliares de crianças com múltiplos acolhimentos institucionais no Distrito Federal (Fukuda, Penso \& Santos, 2013), entre o período de janeiro de 2007 e agosto de 2009, foram contabilizadas a abertura de 545 pastas especiais, ou seja, processos judiciais que tratam de acolhimento institucional de crianças e adolescentes, existentes na Promotoria da Infância e da Juventude. Desse universo, em 28,5\% das pastas havia situações com mais de um acolhimento institucional, ou seja, casos em que a mesma criança ou adolescente é encaminhado para algum abrigo após tentativa de reinserção na família, indicando falhas no processo de reintegração familiar. Vale ressaltar que entre os 28,5\% havia um número considerável de grupos de irmãos $(45,4 \%)$, já que os processos são agrupados por família. Outro dado importante diz respeito ao longo período de acolhimento, pois em 34\% das pastas especiais com casos de recolhimento existiam há mais de três anos.

Nos casos em que os profissionais do serviço de acolhimento buscam alternativas para aproximação entre o acolhido adolescente e sua família, e não obtém sucesso, passam a organizar, junto ao adolescente prestes a completar 18 anos, um plano de intervenção focado na autonomia deste. Porém, um problema aparece: a não disponibilidade de uma renda financeira para a manutenção de uma vida independente. Com pouca escolarização e dificuldade em frequentar cursos de qualificação profissional, o ingresso de muitos desses adolescentes no mercado de trabalho é dificultado, frustrando a concretização do projeto de autonomia. 
Buscando alternativas, percebe-se que muitos meninos e meninas fazem uso de substâncias psicoativas e ingressam no tráfico de drogas para serem acolhidos por um grupo, para serem respeitados e terem acesso a uma renda. Conforme estudo de Pereira (2009), adolescentes que ingressam em grupos ligados a ações ilícitas, como gangues ou outros que realizam tráfico de drogas e roubos, por exemplo, buscam uma proteção que foi perdida ou nunca se concretizou, num grupo onde possam existir e pertencer. $\mathrm{O}$ adolescente em contexto de vulnerabilidade social apresenta dificuldades em atender a alguns requisitos sociais, não acessando o mercado de trabalho formal, por exemplo, passando por situações de discriminação social. Tal situação os impulsiona, muitas vezes, à busca de pertencimento a grupos ligados ao uso de drogas e ao tráfico.

Reconhece-se que o acolhimento institucional, por si só, não conduz os adolescentes ao uso de drogas e ao tráfico de entorpecentes, mas pode ser considerado como um fator de risco para essas situações. Paradoxalmente, um contexto que possui a função de proteger pode, ao mesmo tempo, impulsionar os adolescentes em acolhimento institucional a buscarem outros grupos de pertença, inclusive, aqueles ligados ao tráfico de drogas. Portanto, o tempo de acolhimento institucional deve ser, conforme preconizado, o menor possível. Esse não cumprimento implica em consequências individuais como frustração e abandono de expectativa quanto ao futuro, e no caso de adolescentes, distanciamento de uma rede de pertencimento do mundo fora da instituição de acolhimento, ou cerceamento de vinculações afetivas restritas ao contexto da instituição.

\subsubsection{Adolescentes em acolhimento institucional e em situação de rua}

A partir da proposição de Laberge e Roy (1994), é imprescindível que em uma pesquisa em que os participantes possuem vivência de rua, esteja explícito o que está se delimitando com esse termo, visto que existem múltiplas definições sobre tal situação. As 
autoras sugerem que seja delimitado um público com uma necessidade em particular, situado num determinado momento e que utilizam um serviço específico.

Assim, na presente pesquisa, a situação de rua está relacionada aos adolescentes que estão acolhidos institucionalmente, por meio de medida protetiva e que evadem da unidade de acolhimento e passam dias na rua, muitas vezes nas imediações do próprio abrigo, retornando para a unidade tempos depois. Existem também aqueles que passam a maior parte do dia com atividades na rua, retornando ao abrigo a noite, somente para alimentação e repouso. Em relação às famílias dos meninos e meninas em situação de rua, Ruiz (2013a) indica que, de forma geral, elas apresentam as seguintes características: violência simbólica, verbal e física; alto índice de abuso sexual; elevado consumo de álcool e outras drogas; falta de contenção e relações afetivas positivas; falta de desejo e projeto para os filhos; problemas de relação com as instituições e dificuldades em simbolizar e elaborar. Porém, essas famílias não devem ser vistas como responsáveis pela saída da criança ou do adolescente para a rua, pois trata-se de um contexto familiar com vínculos frágeis e que faz parte de um contexto social que também é composto de vínculos frágeis entre seus integrantes. Muitas vezes, são famílias que, por gerações, não tem encontrado um lugar social por meio do trabalho e da escola, o que denuncia condições de desigualdade social e a fragilização das políticas sociais, nas quais não se garantem direitos mínimos para uma parcela da população.

Assim, o contexto da rua passa a ser uma alternativa viável, muitas vezes a única, onde meninos e meninas podem encontrar modelos de identificação com jovens mais velhos e que enfrentam as dificuldades com força e coragem, mesmo que os introduzam no mundo das drogas e a uma vida aparentemente, sem regras. Conforme apontam Carreteiro e Santos (1999), a rua pode ser considerada como um local de refúgio em consequência de conflitos vividos nas famílias. 
Transpondo para a situação do acolhimento institucional, moradia provisória de adolescentes, pode-se indicar que em muitos casos ocorre uma situação semelhante: adolescentes que buscam na rua vivências mais satisfatórias e prazerosas do que encontradas na instituição, apesar dos riscos aos quais estão expostos. Mesmo vivenciando situações violentas na rua, os adolescentes também vivenciam laços de solidariedade entre os que ali estão (Ruiz, 2013a). Essa dinâmica é interessante, pois indica que o espaço da rua é, em alguns termos, mais atrativa que o espaço do acolhimento institucional.

Parazelli (2000) complementa essa discussão ao indicar que a vivência de rua pode ser uma resposta dos adolescentes à violência familiar e institucional, no sentido de oferecer aos meninos e meninas, uma proteção coletiva. Estar na rua, mesmo com o risco e a insegurança que essa prática possui, é uma forma de sobrevivência identitária, tendo em vista que, muitas vezes, é o único local onde os adolescentes se percebem reconhecidos e onde vivenciam uma solidariedade entre seus pares.

Sobre o conceito de rua, Parazelli (2002a) chama a atenção ao pontuar que esse espaço não designa somente um receptáculo de pessoas ou não se resume às atividades que ocorrem nesse local. Um espaço físico é composto de outros elementos que nos ajudam a compreender porque ele é atrativo ou não a determinado grupo. Assim, é imprescindível analisar as condições presentes nos modos de relação entre as pessoas desse contexto, buscando identificar e compreender elementos que estruturam simbolicamente essa experiência identitária ao longo do tempo. Nesse sentido, pode-se também inferir que o espaço do abrigo institucional é mais que uma estrutura física, onde o contexto das relações presentes impacta, de alguma forma, a construção identitária dos acolhidos.

Então, para a compreensão do que se passa junto a jovens em situação de rua, Parazelli (2002a) apontou alguns indicadores. Num dado contexto, existem o que ele chamou de fatores sociopolíticos e que inclui o previsto para o local em termos concretos, quais sejam: objetivo 
do espaço, pessoas que são autorizadas a acessá-lo, regras de funcionamento como horário de entrada e saída possíveis, comportamentos permitidos ou não e formas de controle e vigilância sobre aqueles que compõem esse espaço. Existe uma tensão entre esses fatores e outros que estão diretamente relacionados, aos quais o autor denominou de fatores antropológicos. Esses últimos dizem respeito aos modos de relação entre as pessoas que fazem parte de determinado local, incluindo percepções e imaginário social. Esse modo de relação vai direcionar o modo de utilização do espaço e os modos de ocupação, esse últimos indicando a temporalidade, periodicidade e formas de apropriação desse espaço.

Assim, o grau de tensão entre os fatores sociopolíticos e os fatores antropológicos vão fazer certo espaço mais ou menos atrativo para os que fazem parte desse contexto. Em outras palavras, quanto maior for a presença do que Parazelli (2002a) denominou de fatores psicanalíticos nessa relação de tensão, maior a atratividade para determinado espaço. Esses fatores psicanalíticos incluem a reciprocidade das relações estabelecidas, a confiança nessas relações e certo grau de indeterminação das regras estabelecidas, oferecendo espaço para a construção coletiva das normas e para o exercício da criatividade nesse contexto.

Nesse sentido, na presente pesquisa, um indicador importante pode ser a identificação dos fatores sociopolíticos presentes no abrigo e que indicam o objetivo desse espaço, o público que pode ser acolhido, os profissionais presentes, as regras de funcionamento, os comportamentos tolerados e os reprimidos e as formas de controle e vigilância utilizadas. Esses fatores estão relacionados aos elementos do contexto social que se procura identificar na pesquisa. Já em relação aos elementos subjetivos, também enfatizados nesta pesquisa, esses relacionam-se aos fatores antropológicos indicados por Parazelli (2002a), pois dizem respeito, numa relação dinâmica, às percepções e interpretações que os indivíduos fazem de determinado contexto, e as reações e relações estabelecidas a partir daí, num movimento contínuo que interfere diretamente na construção identitária desses indivíduos. E tanto os 
fatores sociopolíticos quanto os antropológicos podem ser vistos sob uma perspectiva histórica, ao considerarmos seu processo de construção ao longo do tempo. Com isso, tanto os fatores subjetivos, sociais e históricos, valorizados nesta pesquisa, podem ser identificados a partir da proposta de Parazelli.

Outra questão importante é a possibilidade de negociação entre os fatores antropológicos e os sociopolíticos, aumentando o que Parazelli (2002a) chamou de espaço transicional. Assim, numa instituição de acolhimento, quanto maior a flexibilidade em relação ao que está estabelecido, como regras de funcionamento e formas de controle sobre os acolhidos, maior a presença da reciprocidade nas relações e de confiança, o que facilita o pertencimento a esse local. Mas essa situação também pode ocorrer na rua, pois certa flexibilidade nas regras de organização desse espaço, o grau de abertura para o recebimento de novas pessoas e as formas de controle presentes também podem favorecer um sentimento de pertencimento aos que ali estão. E nessa perspectiva, a investigação do movimento de ir e voltar dos adolescentes entre os espaços do abrigo e da rua pode ser enriquecida por meio dos indicadores propostos por Parazelli, sempre analisando de forma interrelacionada as dimensões subjetivas, sociais e históricas, foco desta investigação.

Em uma pesquisa realizada na cidade de Montreal, Canadá, com jovens em situação de rua (Parazelli, 2000), uma adolescente relata que, após ser encaminhada para uma unidade de acolhimento, fugiu por quatro vezes, num período de três meses e, assim como outros na mesma situação, não compreendia porque os profissionais não a deixavam viver na rua com seus amigos que a amam e a consideravam. Ela justificou suas fugas da instituição pelos limites impostos pela unidade que eram muito restritivos, aumentando nela um sentimento de revolta. Mas, ao mesmo tempo, procurava a instituição pela proteção material que a ela era proporcionada, mesmo que o local não respondesse às suas necessidades afetivas. 
A partir de outra investigação, também feita na cidade de Montreal (Lussier \& Poirier, 2000), junto a 60 jovens adultos em situação de rua, sendo 30 mulheres e 30 homens, viu-se que, ao serem solicitados a falar sobre o que poderia ter desencadeado a vivência de rua, 92\% indicaram que esse processo iniciou-se no contexto relacional ameaçador ou insuficiente da família de origem. As figuras maternas e paternas foram vistas como falhas, situação agravada pela impossibilidade de apoios relacionais auxiliares ou substituições. $\mathrm{O}$ acolhimento pela família extensa, em outras famílias, bem como em instituições, também se apresentaram falhos ou indiferentes e não conseguiram atuar no sentido de promover o acolhimento e a integração desses em seus contextos, restando para o jovem como única alternativa, a fuga. Assim, a partir dessa sequência de falhas relacionais e rupturas, iniciou-se, para o grupo pesquisado, o percurso nas ruas.

Realizar uma investigação num campo que contempla também a vivência de rua, como é o caso desta pesquisa, requer, então, um olhar para o processo de construção das relações interpessoais pois, segundo Lussier e Poirier (2000), no contexto da itinerância em Montreal, Canadá, por exemplo, quando os profissionais que intervinham junto a esse público abordavam questões de sobrevivência material na rua, a maior demanda dos jovens era sobre os aspectos relacionais de sua existência. Focar nos modos de relação é uma forma de atuar que, muitas vezes, vai contra as intervenções realizadas, que buscam reduzir a questão da itinerância das cidades. Pela complexidade da situação e pela diversidade do público em situação de rua, podem-se empreender ações no sentido de resolver outros problemas estreitamente vinculados, porém secundários, como a saúde mental, a criminalidade e a toxicomania. Essas ações não alcançam as diversas causas, os vários significados individuais e os sentidos que essa experiência confere ao contexto social mais amplo, não alcançando, então, seus objetivos. Confrontados às falhas, ameaças e precariedade extrema da acolhida na 
primeira rede de relações interpessoais aos quais integraram, e a impotência de reparação auxiliares ou substitutos, muitos adolescentes são levados à necessidade de ruptura.

Ainda em pesquisa realizada por Lussier e Poirier (2000), o início da itinerância pode ser classificada em dois grandes grupos. O primeiro, caracterizado por experiências de abandono e de rejeição ainda na infância e que se prolongam até a situação de rua, onde dominam a flutuação, a passividade e a impressão subjetiva de declínio e degringolação. Se vêem vítimas seja diretamente (crianças não desejada, violentadas ou encaminhadas para um serviço de acolhimento), seja pela percepção de deserção do meio familiar pelas condições de pobreza, carência e morte. A situação se constitui pelo prolongamento desse primeiro abandono, pela falta fundamental de um enraizamento. $\mathrm{O}$ segundo grupo se constitui de jovens que decidiram cortar sua relação com seu meio de origem, por meio da fuga, esquiva, num movimento de busca de algo que não se sabe muito bem o que no início. Mas vale ressaltar que nenhum dos dois grupos pode reivindicar a exclusividade da vitimização ou da escolha. Nas situações onde os indivíduos escolheram sair do seu meio de origem foram identificadas evidências de uma rejeição anterior, mas cada pessoa vai empregar um sentido subjetivo à própria itinerância, seja de passividade ou de atividade, e que colore de forma diferente cada etapa de aproximação e constituição da situação de rua, sua trajetória.

Uma observação importante realizada no estudo indicou que a vivência no interior de cada tipo de grupo de jovens em situação de rua (vítima/ escolha) são semelhantes, o que não ocorreu entre pessoas desses dois grupos diferentes. Outra questão diferenciada entre esses dois grupos está relacionada às suas reações: o primeiro grupo se posiciona de forma desesperada, enquanto que o segundo faz de sua vivência o motor e a fonte de ímpeto. Observa-se também que questões relacionadas ao amor e a uma necessidade fundamental de aceitação permeia o discurso do primeiro grupo, ao que no segundo prevalecem questões de identidade, integridade e status (Lussier \& Poirier, 2000). 
Lussier e Poirier (2000) também indicam em sua pesquisa que os jovens participantes da pesquisa podem ser divididos em três grupos, segundo a relação parental de origem, informação importante tendo em vista que identificaram que o contexto relacional de origem é de extrema importância no processo de instalação da situação de rua. O primeiro grupo (33\%) percebe a própria itinerância como um prolongamento de uma rejeição, abandono ou desinvestimento por parte da mãe, se ancorando numa experiência de não ser desejado no nascimento, seguido de múltiplas rejeições e tentativas de ser amado. O segundo grupo, com $22 \%$ dos participantes, mostra que o processo de situação de rua se iniciou com um conflito com o pai, aparecendo conflitos de ordem identitária e que se reportam a uma recusa ou impossibilidade de reconhecimento do sujeito pelo pai. Já o terceiro grupo (45\%) indicou dificuldades relacionadas ao pai e à mãe, onde ocorreu uma dupla falha. Mas mesmo com essa divisão, observou-se nos três grupos que as questões fundamentais estão relacionadas ao pertencimento e à inscrição identitária nesse contexto relacional de origem. Os participantes da pesquisa relacionam que a falta de lugar no meio familiar reaparece numa desinscrição social e identitária.

Uma outra pesquisa, realizada com jovens em situação de rua da cidade de Sherbrooke, Canadá (Hurtubise \& Vatz-Laaroussi, 2000), levanta algumas questões interessantes em relação à situação de rua e ao contato com a família de origem. Vale ressaltar que os próprios autores indicam que essa investigação ocorreu em uma cidade de médio porte, com 120.000 habitantes à época, o que pode ter influenciado nas considerações realizadas pelos pesquisadores. Foi identificado que os jovens ainda mantinham algum contato com seus familiares, ficando mães e pais em primeiro plano, aparecendo também o grupo de irmãos e a família extensa, porém, de forma secundária. Nesse contato, ocorriam desde apoio material à intervenção em caso de urgência, passando pelo apoio afetivo e pela escuta. Assim, indica-se que os grupos aos quais os jovens pertencem, mesmo que não tenham contato direto entre 
eles, compõem a rede de apoio do jovem. Em outras palavras, ao se buscar compreender a situação de rua, é importante que toda a rede de relações e de apoio do indivíduo seja considerada, compreendendo que cada ponto dessa rede possui um papel específico e fundamental.

Em relação às estratégias da rede de apoio do jovem em situação de rua, de acordo com Hurtubise e Vatz-Laaroussi (2000), tem-se: estratégia de proteção pela rede em caso de fuga; estratégia de socialização que visa a inserção e proteção dos novos meninos e meninas que chegam à rua, incluindo ações úteis e lúdicas que permitem a vida na rua e estratégia de acompanhamento à saída da rua. Esse último favorece a formulação de um projeto de futuro, relacionado aos recursos, possibilidades, trabalho e formação. Alguns que estão em situação de rua têm o desejo de se tornarem educadores de rua, ajudando outros a saírem da situação de rua. Nesse caso, a rede aparece como um espaço social que favorece certo exercício de cidadania. As estratégias da rede de apoio são variáveis, mas vale salientar que cada membro da rede, quer seja seu lugar ou seu status, também são atores dessas estratégias, podendo atuar como mediadores, intérpretes, acolhedores, líderes ou facilitadores.

Sobre adolescentes acolhidos institucionalmente e que, com frequência, passam longos períodos na rua, foco desta pesquisa, pode-se fazer uma relação com a investigação apresentada acima, no sentido de que o abrigo possui um papel, um grau de importância na rede de apoio desses adolescentes. Explorar as estratégias que se fazem presentes nessa dinâmica pode clarear sobre como essa instituição atua.

\subsubsection{Síntese}

A partir do referencial teórico apresentado neste capítulo, pode-se demonstrar quais concepções e conceitos foram utilizados para embasar este estudo. A Psicossociologia Clínica, por meio do método da história de vida que, nesta pesquisa, foi muito influenciada 
pela Sociologia Clínica, permitiu uma leitura tanto de elementos da estrutura social, quanto da influência dessa organização coletiva para a constituição da subjetividade do indivíduo e suas possíveis reações, no contexto do acolhimento institucional de adolescentes.

Este estudo valorizou uma aproximação entre a pesquisadora e os participantes da investigação, no sentido de, a partir de um viés clínico, entrar em contato com a subjetividade daqueles que participaram do estudo. E nesse sentido, tanto a implicação da pesquisadora, quanto a valorização dos diversos saberes existentes junto aos participantes, foram fundamentais para maior compreensão do fenômeno estudado.

Apresenta-se ainda, neste capítulo, em termos gerais, o conceito de hipermodernidade, enquanto uma leitura de organização e funcionamento de nossa sociedade atual, que contém características importantes e que afetam tanto os grupos quanto o indivíduo, tais como competição, clima de urgência permanente e individualismo (Aubert, 2012). E nesse contexto, indica-se a repercussão no processo de construção identitária dos indivíduos, por exemplo, por meio do sentimento de vergonha, quando a pessoa não alcança um padrão social aceito e esperado pela maioria, ou por meio do sentimento de humilhação, nos casos de desqualificação social (Léonetti, 2007c).

E essas repercussões de um contexto coletivo sobre um indivíduo, são importantes de serem consideradas na análise do contexto do acolhimento institucional de adolescentes que possuem vivência de rua, pois clareia como uma situação social pode marcar uma história de vida em particular, influenciando as reações e as escolhas desses meninos e meninas. E aproxima essa vivência dos adolescentes do processo de exclusão social, na medida em que, no geral, os vínculos familiares e sociais estão fragilizados, eles são vinculados como usuários de um serviço de assistência social, que é o de acolhimento institucional, além de também ficarem tempos na rua. 
Assim, a fragilização da rede relacional de um indivíduo, que é um indicador do processo de exclusão social, segundo Castel (1994), a também fragilização dos vínculos sociais de modo geral, marcante em uma época hipermoderna, bem como as repercussões de todo esse contexto para a subjetividade dos indivíduos, pode favorecer o que Léonetti (2007a) chamou de processo de desinserção social. Em cada etapa desse processo, Blondel (2007) indicou as possíveis reações subjetivas dos indivíduos frente a esse cenário, quais sejam resistência, adaptação e instalação, haja vista que o indivíduo não recebe qualquer influência do meio coletivo e social de forma passiva. E a partir dessas reações subjetivas, pode-se compreender algumas posturas e comportamentos de pessoas em situação de desinserção social, mais especificamente neste estudo, de adolescentes em acolhimento institucional e com vivência de rua.

Outro tópico também apresentado neste capítulo foi a definição do serviço de acolhimento institucional, bem como um breve histórico desse serviço no Brasil. Se está-se abordando a história de vida de pessoas ligadas à esse serviço, é essencial também compreender-se a história das instituições relacionadas ao acolhimento, no intuito de se identificar pontos dessas histórias que se cruzam e que se influenciam. Dois assuntos específicos foram discorridos, sendo eles o tempo do acolhimento institucional e os modos de intervenção profissional educativos e disciplinadores. Por meio desses dois tópicos, indica-se que na atualidade, há ainda reflexos de modos de organização institucional relativos ao Código de Menores, que se atualizam, muitas vezes de forma indireta, em práticas institucionais do serviço de acolhimento da atualidade. Também expressaram elementos do fenômeno de meninos e meninas em situação de rua, para nos auxiliar a compreender o movimento de adolescentes que ficam em trânsito entre a rua e a instituição de acolhimento. Os indicadores de Parazelli (2002a) traçam elementos a serem considerados no que diz respeito a um lugar ser atrativo ao não a jovens, o que lançou luz ao fenômeno estudado nesta investigação. Então, após 
sustentação teórica para a presente pesquisa, apresentar-se-á no capítulo seguinte o método utilizado, condizente com os pressupostos da Psicossociologia Clínica. O contexto do estudo será demonstrado, bem como os participantes, o modo de acesso às histórias de vida, a análise das informações bem como os cuidados éticos tomados. 


\section{MÉTODO}

A presente pesquisa apresenta como método a abordagem qualitativa, no qual buscouse um conhecimento profundo sobre a complexidade dos fatos e processos singulares a grupos e indivíduos. A partir dessa perspectiva, é possível que aspectos da subjetividade, imersos no contexto social, surjam, oferecendo sentido às ações e relações até então existentes (Paulilo, 1999). Vale ressaltar que a pesquisa qualitativa analisa microprocessos, por meio do estudo das ações sociais individuais e grupais, sendo flexível quanto à coleta de dados e exigindo do pesquisador uma capacidade integrativa e analítica frente à realidade que se apresenta (Martins, 2004).

Com base na abordagem qualitativa, o trabalho com as histórias de vida dos participantes foi utilizado como um modo privilegiado de se ter acesso à proposta da Psicossociologia Clínica, que é a presença da história de um coletivo, de uma sociedade, na história de vida de uma pessoa. Assim, foi possível apreender a relação existente entre os indivíduos e entre estes e a sociedade onde vivem, como uma espécie de "escuta clínica do social" (Takeuti, 2009, p. 76). Conforme apontado por Gaulejac (2009), pode-se compreender os destinos humanos a partir de histórias de vidas, observando-se a subjetividade, os determinismos sociais, as escolhas e as rupturas de sua existência que se inter-relacionam de forma complexa. Além do mais, "o relato de vida é um instrumento de historicidade, pois permite que o sujeito 'trabalhe' sua vida. Contar sua história é um meio de jogar com o tempo da vida, de reconstruir o passado, de suportar o presente e de embelezar o futuro" (Gaulejac, 2009: p. 65).

Na pesquisa, foi privilegiado o significado subjetivo dos participantes da pesquisa em relação à sua história de vida, com foco na vivência de acolhimento institucional, pois a reconstrução desses pontos de vista pode indicar aspectos da esfera social da qual fazem parte (Flick, 2009). Considerou-se também um dos pressupostos da abordagem clínica que trata da 
aproximação ao outro, ou seja, é possível compreender melhor a prática dos adolescentes ao acessar suas histórias de vida, suas percepções, seus sentimentos e o conhecimento acumulado ao longo do que foi vivido. Uma pesquisa clínica não busca somente explicar como uma situação ocorre, mas se preocupa, na mesma medida, em compreender como tal situação é interpretada pelos atores envolvidos (Sévigny, 2001). Assim, utilizando as histórias de vida como método, a partir de uma abordagem clínica, é possível ter acesso tanto à dimensão subjetiva, do indivíduo, quanto à dimensão coletiva, da sociedade, o que favorece uma leitura mais ampliada do fenômeno apresentado, que, no caso desta pesquisa, diz respeito ao acolhimento institucional de adolescentes. Vale ressaltar, como apontou Sévigny (2001), que as representações que os indivíduos apresentam de um contexto social, ou coletivo, são importantes numa pesquisa clínica.

Porém, como pontou Parazelli (2000), no caso de adolescentes que transitam entre a instituição de acolhimento e a rua, estar na rua possui significados únicos para cada um que ali está, que percebem as múltiplas experiências que esse espaço comporta de forma singular. Por exemplo, mendigar, pedir dinheiro, pode ser visto por uns como uma atividade de emancipação, pois oferece certa autonomia financeira para o indivíduo, ao mesmo tempo que para outros, a mesma atividade pode ser traduzida como uma prática alienante e que reforça uma relação dependente daquele que mendiga. Então, para que se possam compreender as questões que atravessam cada história de vida, é essencial conhecer os sentidos que cada um confere à própria vivência.

Para isso, é importante um método qualitativo que coloque em primeiro plano, a fala dos participantes, buscando uma aproximação do processo de constituição da subjetividade, porém, sem perder de vista a complexidade e os elementos sociais que se fizeram presentes (Lussier \& Poirier, 2000). Ferrarotti (1990b) indica que a escuta da subjetividade e do vivido pelo outro, que diz de uma abordagem clínica de investigação, sintetiza tanto uma prática 
individualizada, quanto a prática de todo um contexto social, com seus diversos atores. Assim, essa pesquisa procurou acessar não somente o vivido por adolescentes que estão em uma unidade de acolhimento e por um profissional que atua nesse contexto, mas também buscou identificar elementos do funcionamento dessa instituição que atuam diretamente nas trajetórias dos que ali são acolhidos. Vale ressaltar que uma história de vida não reflete simplesmente o social, mas sim uma leitura, uma interpretação que o indivíduo faz desse contexto. Em outras palavras, uma pesquisa desse tipo não é generalizável, mas consegue captar elementos tanto subjetivos quanto do contexto social, podendo auxiliar na análise de outros contextos semelhantes.

Sobre contexto social, Bertaux (2013) indica alguns pontos a serem considerados. Uma situação social particular não implica necessariamente a formação de um mundo social homogêneo, citando como exemplo as pessoas que estão desempregadas por longo tempo. Elas não possuem necessariamente características individuais comuns ou não possuem as mesmas atividades cotidianas, mas o que as liga, o que as torna parte de uma situação social, é o fato de estarem por longo tempo sem um emprego formal. E essa situação é social na medida em que, mais ou menos, as mesmas restrições e as mesmas tensões estão presentes em cada uma delas, levando também a ações e reações que se assemelham, por vezes, entre si.

Assim, tem-se, como situação social, privilegiada por esta pesquisa, adolescentes que são acolhidos em uma instituição e que, por não conseguirem permanecer o tempo todo na instituição, buscam outras alternativas, como a vivência de rua. Esses adolescentes são diferentes entre si, estão acolhidos por motivos distintos e possuem uma história de vida particular, mas todos fazem parte da mesma instituição e, ao mesmo tempo, buscam realizar algumas atividades na rua, fora dos limites do abrigo. E por fazerem parte de uma mesma dinâmica coletiva, compõem uma situação social. Como enfatiza Bertaux (2013), a pesquisa com histórias de vida é eficaz no sentido de oportunizar a compreensão dos mecanismos que 
atuaram na formação de uma situação social, o conhecimento das características profundas dessa situação, com as tensões que a atravessam e a caracterizam, bem como a forma na qual as pessoas se encontram nessa situação e como se esforçam para geri-la, ou sair da mesma. Então, é possível, de acordo com Gaulejac (1994e), que se apreenda o complexo dinâmico de desinserção social.

Considerando que as instituições mediam e reproduzem elementos do contexto social mais amplo (Ferrarotti, 1990b), pode-se propor o espaço de uma unidade de acolhimento institucional para compreender o movimento de adolescentes que, por mais que estejam nesse espaço, buscam as ruas para passarem momentos, por vezes longos, de suas vidas. Mesmo que cada indivíduo faça uma leitura individualizada dos grupos aos quais pertence, existem pontos que são compartilhados entre os que compõem o mesmo grupo, auxiliando o pesquisador, então, na compreensão desse contexto social mais amplo.

\subsection{Contexto}

Esta pesquisa foi realizada com participantes de dois abrigos institucionais do Distrito Federal, sendo que um recebia crianças e adolescentes com medida protetiva de acolhimento, e outro, adolescentes que estavam em situação de rua, sem medida judicial. A primeira instituição contava com uma sede, na qual, além de espaço administrativo, continha três unidades residenciais em seu interior. Pela disposição do seu espaço físico, era considerada como abrigo institucional, pois acolhia uma média de 30 adolescentes diariamente. Em relação à segunda instituição, além de acolher somente meninos e meninas em situação de rua, era deixado a cargo do adolescente decidir ficar ou não na instituição. E essa decisão muitas vezes facilitava a atuação dos profissionais junto aos acolhidos, pois indicava algum tipo de compromisso do adolescente com a unidade. 
Nesse contexto, a adolescente Simone participante desta pesquisa somente tinha sido acolhida na primeira instituição aqui apresentada, diferente do adolescente Marcos que, após passar um pouco mais de dois anos nesse primeiro abrigo, foi encaminhado para a segunda instituição, que acolhia meninos e meninas que estavam em situação rua. Sobre a profissional Alice, que também participou desta pesquisa, ela era assistente social da primeira instituição.

\subsection{Participantes}

A escolha dos adolescentes participantes de uma pesquisa com histórias de vida requer cuidado, no sentido de que precisa haver disponibilidade desse adolescente em narrar sua história, haja vista que esse não é um processo simples e que, muitas vezes, leva o indivíduo e entrar em contato com memórias de situações violentas e angustiantes. Então, um primeiro ponto a se considerar é a aceitação do adolescente em participar da pesquisa, ao mesmo tempo em que o pesquisador precisa estar atento para ouvir o que ele tem a dizer, seja o que for. Com essa postura, o pesquisador possibilita a construção de uma relação de confiança entre ele e o adolescente, permitindo que a menina ou o menino exponha o que viveu, o que percebeu e o que sentiu ao longo da vida.

Assim, como participantes desta pesquisa, tem-se dois adolescentes de unidades de acolhimento, um do sexo feminino e outro do sexo masculino, que apresentavam a prática de evadir da instituição para ficar horas ou até dias na rua. Por um período, ficaram acolhidos na mesma instituição. A escolha desses dois participantes deu-se porque a pesquisadora já os conhecia e conseguia ter uma aproximação com eles que permitisse algum grau de confiança, para que contassem a própria história de vida. A pesquisadora já havia trabalhado como coordenadora do abrigo em que eles estavam acolhidos. Porém, para participarem da pesquisa, após a pesquisadora apresentar sua investigação e tirar as dúvidas dos adolescentes em relação a esse assunto, sempre buscando falar com uma linguagem acessível aos jovens, 
os adolescentes concordaram e assinaram o Termo de Consentimento Livre e Esclarecido (Apêndice A), conforme exigência da Resolução 196, que trata de pesquisas envolvendo seres humanos (CNS, 1996).

Em uma unidade de acolhimento institucional, o dirigente da instituição, conforme indicado na Lei Federal $\mathrm{n}^{\circ} 12.010$, artigo $92, \S 1^{\circ}$, é equiparado, juridicamente, ao guardião dos acolhidos para todos os efeitos de direito. Assim, os coordenadores das unidades em que os adolescentes estavam acolhidos, também assinaram o Termo de Consentimento Livre e Esclarecido.

Considerando a importância dos diversos tipos de saberes para a compreensão de um fenômeno social, além do saber científico e da experiência protagonizada pelos adolescentes, também foi considerado o saber da prática, presente nesta pesquisa por meio da trajetória profissional de uma assistente social que trabalhava em um abrigo institucional. Esse abrigo é o mesmo em que os dois adolescentes, participantes dessa pesquisa, foram acolhidos por um período. Ela também assinou o Termo de Consentimento Livre e Esclarecido. Ao cruzar os saberes de senso comum, da prática profissional e o científico, sem hierarquizá-los, conforme sugere a abordagem clínica, buscou-se uma maior compreensão do fenômeno social estudado.

\subsection{Acesso às trajetórias de vida: delimitação conceitual e procedimento de pesquisa}

A presente pesquisa é integrante da pesquisa interinstitucional, com participação de professores e alunos da Universidade de Brasília e Universidade Católica de Brasília, intitulada "Crianças e adolescentes abrigados no Distrito Federal: estudos das condições familiares, institucionais e sociais". A referida pesquisa interinstitucional teve seu projeto submetido ao Comitê de Ética em Pesquisa, da Universidade Católica de Brasília, e por atender à Resolução 196 (CNS, 1996), foi aprovada por meio do parecer $\mathrm{n}^{\text {0 }}$ 056/2010 (Apêndice B). Nesse contexto, a presente pesquisa se insere nesse grupo de pesquisa, a fim de 
contribuir para a investigação por meio do acesso às histórias de vida de adolescentes que possuem, além do acolhimento institucional, vivência de rua.

Assim, nessa pesquisa, o acesso às histórias de vida dos adolescentes ocorreu por meio de entrevista aberta, gravada em meio digital, na qual eles foram demandados a contar sua trajetória de vida, com foco na experiência do acolhimento institucional em abrigo e na vivência de rua. $\mathrm{O}$ número de entrevistas dependeu da disponibilidade deles em falar sobre suas histórias, mas tendo como referencial certa saturação do tema proposto pela pesquisa, estando pesquisador e participante de acordo nesse ponto (Legrand, 1993).

Já em relação à assistente social, ela contou sua trajetória profissional, incluindo formação e trabalhos desenvolvidos, que também foi gravada em meio digital. Essa entrevista teve como norte um roteiro preestabelecido (Apêndice C), adaptado de outro utilizado em pesquisa no contexto de um abrigo comunitário para jovens em dificuldade na cidade de Montreal (Roy, Rhéaume \& Hétu, 1998). Para tanto, a postura da pesquisadora, diante das três entrevistas realizadas, foi a indicada por Grell (1986), quer seja a de escutar, se informar e questionar, mas sempre deixando o participante da pesquisa na sua função ativa, valorizando seu saber.

Para Grell (1986), a entrevista precisa respeitar alguns princípios: deve permitir e favorecer sua dupla função de expressão e criação, além de permitir que o participante tenha o controle da entrevista, seja realmente autor de sua história. Para isso, o pesquisador deve ouvir para compreender. E para favorecer essa exploração, conforme Gaulejac e Hanique (2012), podem-se propor suportes metodológicos, ferramentas escolhidas empiricamente que facilitam a narração de sua história por parte do participante e a implicação e análise por parte do pesquisador. Takeuti e Bezerra (2009) pontuam o uso de elementos mediadores para favorecer a expressão da própria história de vida. Nesse sentido, no caso dos adolescentes, foi oportunizado que desenhassem livremente durante a fala, sendo oferecido papel, caneta, 
borracha, lápis preto e colorido. Pineau (1986) reforça a aplicabilidade da ideia aqui empregada, ao afirmar que a produção biográfica é realizada por meio da linguagem, não importa qual, e que por vezes, é importante completar a linguagem corrente com outros tipos de linguagens. Nesta pesquisa, a linguagem complementar foi a linguagem gráfica, o desenho.

\subsection{Análise das informações}

A análise das histórias de vida narradas pelos participantes foi realizada em dois níveis, pois essa forma permite um aprofundamento gradativo na compreensão do fenômeno estudado, organizando melhor os dados. O primeiro nível foi o descritivo cronológico e o segundo, o nível temático. Além da análise das entrevistas dos participantes, foi realizada uma meta-análise da investigação, na qual buscou-se identificar elementos que atravessaram a pesquisa e influenciaram o curso dessa investigação.

\subsubsection{Nível descritivo cronológico}

De posse das gravações das entrevistas, estas foram transcritas integralmente (Legrand, 1993) e literalmente. Em seguida, cada história foi organizada cronologicamente, em que as situações narradas foram apresentadas seguindo a ordem temporal nas quais ocorreram, iniciando da mais antiga para a mais recente. Com isso, foi possível descrever o processo de formação de cada história de cada participante. Vale ressaltar que as histórias dos adolescentes apresentaram-se de forma caótica, no sentido cronológico das vivências, sendo importante, então, a organização destas vivências no tempo e, também, a preservação de certa maneira de falar dos adolescentes, para não descaracterizar as histórias narradas por eles.

A fim de facilitar a compreensão dos elementos que atravessaram e influenciaram essas histórias, cada sequência cronológica foi subdividida em tópicos, sendo cada tópico 
representativo de um contexto onde as situações ocorreram. Por exemplo, a história de vida do participante Marcos foi subdividida tendo como referência os diferentes locais nos quais viveu, sendo em sua maioria, instituições de acolhimento. Então, o primeiro período faz parte de um tópico que apresenta sua vivência no primeiro abrigo e, o segundo tópico, é relativo ao vivido no segundo abrigo, e assim sucessivamente. Como outro exemplo, sobre a trajetória profissional da assistente social, seu relato foi dividido de acordo com os locais em que atuou profissionalmente, no qual identificou-se características peculiares em cada contexto.

Após a organização das entrevistas, cada história foi apresentada para cada participante, cada um tendo acesso somente à própria história, a fim de se verificar se o escrito correspondia ao que narraram e se gostariam de acrescentar alguma informação ao texto. Além do mais, coerente com a abordagem clínica que permeia essa pesquisa, tal postura possibilitou aos participantes que se apropriassem de suas histórias e reagissem a elas, percebendo suas trajetórias, seja de vida, seja profissional, com mais clareza.

\subsubsection{Nível temático}

Após a finalização do nível de análise descritivo cronológico, foi realizada a análise temática, sendo que os temas foram organizados a partir do referencial teórico utilizado nesta pesquisa. De forma geral, os temas dizem respeito às diferentes questões, situações ou sentimentos que atravessam diversos períodos de uma história de vida (Legrand, 1993).

Em relação aos participantes adolescentes, foram três os temas analisados. O primeiro tema analisado nas entrevistas dos adolescentes foi: estratégias de respostas desses face às situações sociais que vivenciaram, a partir das considerações de Blondel (2007) sobre as fases de reação do indivíduo que ocorrem em cada etapa do processo de desinserção social, quais sejam resistência, adaptação e instalação. Também considerou-se a indicação de Gaulejac (2006f) sobre essas estratégias, o qual afirma que elas podem ser identificadas por meio dos 
sentimentos de cada pessoa, tais como humilhação, vergonha e revolta, pois eles indicam como dada situação social repercutiu no sujeito, influenciando a elaboração dessa ou aquela estratégia de resposta. Assim, ao se identificar alguns sentimentos dos adolescentes, além de alguns comportamentos, pode-se compreender algumas estratégias de respostas às diversas situações vivenciadas, com os significados conferidos pelo participante.

Já o segundo tema estava relacionado à tensão entre a instituição de acolhimento e a rua, quando foram utilizados os indicadores propostos por Parazelli (2002a). Assim, buscouse identificar os fatores sociopolíticos e os fatores antropológicos, tanto do abrigo quanto da rua, além da interação entre eles, no sentido de analisar a atratividade ou não desses espaços para os adolescentes, por meio dos fatores psicanalíticos.

Como terceiro e último tema analisado a partir das histórias de vida dos adolescentes, temos a representação imaginária a partir dos desenhos. Como uma primeira perspectiva, considerou-se o que o participante disse sobre o próprio desenho, quando pôde indicar quais os significados que estavam presentes em sua produção gráfica. A partir de uma segunda perspectiva, relacionou-se ao conteúdo que emergiu do diálogo entre o participante e a pesquisadora sobre o mesmo desenho, e a pesquisadora procurou melhor compreender o que foi colocado por meio de questões de reflexão sobre a referida produção gráfica. E por fim, a terceira perspectiva ocorreu em relação à interpretação que a pesquisadora fez dos desenhos, na qual buscou-se relacionar o conteúdo narrado sobre as histórias de vida com o conteúdo apresentado no papel. Vale ressaltar que essa terceira perspectiva somente buscou indícios de elementos concretos, gráficos, das histórias narradas, mas não pretendeu impor uma análise que não considerasse o olhar e a interpretação do próprio adolescente. Assim, foi possível compreender a história de vida numa dimensão interativa entre pesquisador e participante, evitando-se interpretações equivocadas que não têm qualquer relação com o vivido pelo indivíduo. 
E para a análise temática da entrevista com a assistente social, o tema abordado foi: aspectos organizacionais sobre o acolhimento institucional de adolescentes. Assim, ao se cruzar a atuação da participante com os pressupostos que orientaram suas ações ao longo do tempo, pode-se melhor compreender o que estava subjacente a cada intervenção e os significados conferidos a essas práticas.

\subsubsection{Meta-análise}

Além da análise das entrevistas, foi realizada uma meta-análise, que considerou a relação da pesquisadora com seu estudo, ou seja, a implicação da pesquisadora com a investigação e com participantes dessa investigação. Foram identificadas as motivações da pesquisadora em realizar essa pesquisa, as repercussões desse processo na pesquisadora e suas reações. Além do mais, foram explicitados os vieses que atuaram durante todo o processo de investigação, tais como condições de produção da investigação, aspirações, crenças e desejos da pesquisadora (Amado, 2005). A análise da implicação da pesquisadora neste estudo foi essencial pois, a partir dessa postura crítica, tornou-se possível uma maior clareza dos elementos que atravessaram esse processo e influenciaram a condução da pesquisa.

\subsubsection{Cuidados éticos}

Em relação ao retorno aos participantes sobre sua participação nessa pesquisa, consideramos o que indica Gaulejac (2005b) ao afirmar que, ao falar de sua história, possibilita-se ao sujeito mudar sua relação com a própria história, ressignificando-a. Essa maior compreensão da própria trajetória, por meio da compreensão dos acontecimentos que compuseram sua própria existência, um outro olhar sobre ela e a possibilidade de efeitos na conduta dos participantes foi a contribuição desta pesquisa aos três participantes envolvidos. 
E também, como apontou Émond (2007), um sofrimento compartilhado pela narração da história de vida torna-se um semi-sofrimento. 


\section{ESTUDO 1 - MARCOS : A TRAJETÓRIA DE VIDA QUE SE CONFUNDE COM A HISTÓRIA DO ACOLHIMENTO INSTITUCIONAL}

\subsection{NÍVEL DESCRITIVO-CRONOLÓGICO}

O acesso à história de vida de Marcos se deu por meio de nove entrevistas, onde foram realizadas entrevistas abertas e quando ele poderia falar de suas vivências livremente. Os encontros se dividiram em dois momentos. O primeiro momento ocorreu quando Marcos estava acolhido na Instituição D, com 17 anos. A última entrevista foi realizada assim que ele foi aprovado para participar de um projeto, no qual receberia uma bolsa de estudos para cursar a escola regular pela manhã e fazer cursos profissionalizantes à tarde, durante um ano. As entrevistas seguintes foram feitas em um momento posterior, quando ele estava na fase adulta, morava na casa de uma ex-cuidadora social e tinha acabado de ser liberado do Sistema Penitenciário. Tinha sido preso por tráfico de drogas, mas foi solto após dois meses por falta de provas contra ele.

O critério para o término das entrevistas foi o de Marcos ter apresentado à pesquisadora sua trajetória de vida desde quando era criança até aquele momento. Foi sendo percebido, tanto pelo participante quanto pela pesquisadora, que ele já havia expressado grande parte das experiências de todas as suas fases de vida.

\subsubsection{Instituição A: dos 0 aos 9 anos}

Marcos foi encontrado em uma lata de lixo por volta dos 9 meses de idade em uma cidade do interior do Centro-Oeste, e encaminhado a um abrigo institucional local. A instituição ficava numa área rural e era composta por várias casas, além de haver criação de

animais (cavalo, gado, galinha e porco) e plantação (horta e árvores frutíferas). Como não havia transporte para levar os meninos à escola, todos ficavam sem educação formal. Marcos 
e seus colegas às vezes fugiam e iam para a escola mais próxima e, chegando no local, os funcionários deixavam que eles entrassem para comer alguma coisa. Porém, ao regressarem ao abrigo, apanhavam de pessoas da equipe por terem fugido para a escola.

Os adolescentes acolhidos, maiores do que ele, forçavam Marcos a brigar com outras crianças, que eram suas amigas. Ele tinha que bater até o outro sangrar. Às vezes, quando um amigo pequeno era obrigado a brigar com outra criança, ele assumia seu lugar para poupar o amigo. Os mais velhos o humilhavam e o faziam beber xixi de cachorro e comer fezes de cachorro, colocando-o no chão. Um outro tipo de humilhação ocorreu quando "humilharam sua bunda", mas sem "penetrá-lo". Desde os 6 anos de idade começou a ver esse tipo de coisa acontecer na Instituição A.

Uma vez ele e outros dois colegas estavam brincando no quarto, quando um dos meninos saiu e o outro colega fechou a porta do quarto. De repente, esse menino segurou o braço de Marcos muito forte, o que deixou os dedos marcados no seu braço, e pediu para Marcos tirar a roupa, mas ele começou a chorar porque não queria tirar a roupa. Marcos ficou nervoso porque não podia sair do quarto. $\mathrm{O}$ menino tirou a roupa e quando Marcos olhou, viu "o tamanho do trem do bicho, desse tamanhão aqui" e o pênis do Marcos era "pequenininho". Então, Marcos conseguiu correr para a porta e quando abriu, o outro menino já estava voltando. Por sorte, nesse dia não aconteceu nada.

A primeira vez que foi abusado sexualmente foi por uma menina, adolescente, que dormia com ele. Marcos tinha 6 anos de idade. Essa adolescente, chamada Ângela, enquanto ele dormia, chupou o pênis dele "muito" e a pele "abriu, secou e não queria voltar para o lugar". Marcos teve que ir para o hospital. Desde pequeno tomava banho com outras meninas e eles ficam "atentando" ele e diziam "olha o pauzinho dele", que ficava ereto. E Marcos cresceu vivendo esse tipo de situação. Um adolescente de 17 anos chamado Walter também abusou dele quando Marcos tinha 8 anos de idade. Ele quase "penetrou nele". A experiência 
nessa instituição fez com que Marcos desacreditasse da vida e não confiasse em ninguém. Viu muitas vezes meninas sendo estupradas. Os meninos mais velhos se aproximavam com jeito e transavam com as crianças e com os adolescentes também. Para conseguirem se aproximar das crianças e abusar sexualmente delas, ofereciam alguma coisa, como por exemplo, uma bala. Para Marcos, as crianças eram inocentes e não sabiam de nada. Para se proteger, Marcos ficava boa parte do tempo no mato, com os animais. Havia um funcionário que o considerava como filho, então Marcos ficava perto dele ou de outro que sabia que não iria abusar dele.

Uma vez, quando Marcos estava com 8 anos e usava um short vermelho, curto, um menino o chamou para uma área verde próxima à instituição. Lá, esse menino abusou sexualmente de Marcos, "totalmente". E quando voltou para a instituição, os outros meninos ficaram rindo dele porque tinham visto o que havia acontecido. Foi a maior humilhação que passou na vida. E, para completar, esses meninos o chamavam de lixeiro, lembrando que sua mãe o tinha jogado no lixo, deixando-o ainda mais revoltado. Desde pequenininho era malicioso e com a "mente estressada".

No tempo em que ficou acolhido, passou fome várias vezes, pois não havia uma pessoa que se responsabilizasse pelo cuidado de todos os acolhidos, principalmente em relação à comida. Somente comia farinha, açúcar e farinha com óleo. Muitas vezes, algumas pessoas trabalhavam no abrigo por aproximadamente cinco meses, cuidando das meninas e dos meninas, porém, depois desse tempo, iam embora. Essa situação era ruim porque Marcos se apegava afetivamente a elas mas, elas iam embora e não voltavam. Algumas vezes, Marcos e seu amigo Paulo pegavam um cavalo e iam a um lago que existia nas proximidades, para brincarem. Mas a vida na instituição era difícil, pois o diretor abusava sexualmente dos meninos e de Marcos também.

Apesar desse contexto, para ele a infância tem um lado positivo, porque é quando se descobre o mundo, se descobrem coisas novas, mas o ruim é que a dele passou muito rápido. 
Viu e passou por coisas que crianças não podem ter contato, como violência sexual e violência física. Os adultos não o protegeram. "Criança tem a mente fraca, é fácil de manipular". Muitos adultos diziam que gostavam dele e que iriam adotá-lo, mas era tudo mentira. Assim, desistiu da vida e dava um jeito de afastar as pessoas dele. Quando foi transferido para outra unidade de acolhimento, não explicaram o que estava acontecendo. Com ele foram mais três: Paulo, André e Fábio. Esses três eram seu amigos, como se fossem irmãos. Brigavam entre si mas, depois, brincavam novamente.

\subsubsection{Instituição B: dos 9 aos 15 anos}

Aos 9 anos de idade, Marcos foi transferido para outra instituição que ficava em uma área urbana, agora já no Distrito Federal e que era composta de várias casas. Ele pensou que as pessoas do local eram "doidas", pois tudo era muito diferente do que conhecia até antão. Ganhou muita roupa, o que nunca tinha acontecido a ele antes. O dia em que foi em um mercado, ficou admirado em ver tanta coisa para comer em um único lugar. Viu que o mundo era maior do que imaginava. Havia umas mulheres com roupas diferentes, oferecendo suco de graça. Ficou muito feliz. Compraram para ele um refrigerante com a tampa do Pokémon (um desenho animado da época) e, com isso, foi um dos dias mais felizes da vida.

Mas foi crescendo e foi ficando para trás em relação aos outros três que também foram transferidos com ele. Fábio voltou a morar com a mãe, e Marcos passou a desejar que aquela mãe também fosse a mãe dele. Começou a frequentar uma escola da localidade, mas era discriminado. Um dia, a professora pediu para que os alunos contassem a história deles e Marcos falou do que passou no primeira instituição de acolhimento, inclusive sobre as violências que sofreu. Falou que ainda morava num abrigo, que tinha sido encontrado em uma lata de lixo quando era bebê e que não conhecia seus pais. Assim, os alunos, que eram 
melhores de vida que ele, começaram a chamá-lo de lixeiro, como ocorria quando estava na Instituição A.

Depois desse episódio, achou melhor "matar" aula pois percebeu que as pessoas não acharam sua história muito normal, e o olhar das pessoas o machucava amargamente. Além do mais, ele era o aluno mais alto da sala, pois estava atrasado em relação à série que deveria cursar pela sua idade. Foi ficando cada vez mais agressivo, batia nos alunos, foi expulso da sala de aula várias vezes e recebeu várias advertências.

Seu amigo Paulo o chamava para faltarem à aula e ele aceitava, e iam para um lago que havia nas proximidades. Esse momento era bom porque lembrava o primeira instituição em que morou, onde também havia um lago. Também começaram a roubar num mercado da região. A ideia era de Paulo que, mesmo sendo mais novo, era mais esperto, mas a culpa sempre caía em Marcos.

Um dia, na escola, quando estava com 10 anos de idade, aconteceu uma coisa que mexeu muito com ele. Um outro aluno da sua escola abusou sexualmente de uma aluna que tinha Síndrome de Down. Esse aluno era da mesma instituição que Marcos e, quando os funcionários falaram com ele, esse disse que na verdade foi Marcos que havia abusado da menina. Marcos chorou, dizendo que não tinha sido ele, mas ninguém acreditou. Isso o deixou revoltado, mas ele não poderia ser preso com essa idade. Porém, as pessoas passaram a olhálo como se ele fosse um estuprador. E a mãe da menina o chamava de maníaco. Mesmo não sendo ele, esse acontecimento foi registrado no seu prontuário do abrigo, contribuindo para que as pessoas, no futuro, o chamassem de estuprador e de maníaco.

O que o deixava estressado era o fato de as pessoas somente considerarem o que estava escrito no seu prontuário, nos relatórios que os psicólogos e assistentes sociais escreviam sobre ele. Todos os da equipe falavam que ele era revoltado e que não tinha jeito. Ele foi prejudicado pois os profissionais que escreviam os relatórios não ouviam o que ele 
tinha a dizer. Quando o chamavam para conversar, eles interpretavam mal o que ele dizia. E ele não conseguia se defender porque ele já tinha um rótulo. Se acontecesse um roubo ou outra coisa de errado, já diziam que era culpa dele.

Nessa segunda instituição havia uma mãe social, responsável por cuidar dos acolhidos da casa onde estava, que tinha por nome Maria, a quem Marcos chamava de mãe. Mas de vez em quando ela pedia para que ele não a chamasse de mãe, o que o magoava muito. Então ele chorava, mas não na frente dela. Na mesa do jantar, muitos meninos e meninas diziam que iriam passar o final de semana na casa de um familiar, mas ele não tinha para onde ir, sempre passava os finais de semana sozinho na instituição. A mãe social Maria tinha um período de folga do trabalho, quando saía para "resolver a vida dela". Então Marcos foi percebendo que ele, na verdade, não tinha ninguém.

No Instituição B tinha mais condição de estudar, de ser alguém na vida. Fez dois anos de preparação para ser coroinha na igreja católica. Para ele, esse abrigo era como sua família, as pessoas se preocupavam com ele, mas ainda achava que tinha pouca atenção dos profissionais. Um dia, Marcos ganhou uma bicicleta e um videogame, denominado Play Station I, mas ele vendeu o videogame para um soldado que conhecia, por $\mathrm{R} \$ 80,00$. Chegou à noite no quartel, que ficava próximo à instituição de acolhimento, e alguns soldados apontaram armas para ele, já que não o conheciam. Depois de tudo esclarecido, Marcos esperou o amigo chegar pela manhã e vendeu o videogame para ele. Com esse dinheiro, comprou uma bicicleta por R\$70,00, já que a outra era muito "fraquinha”. Gostava de jogar Kalter Strike e GTA numa lan house, local onde havia jogos eletrônicos, além de gostar de comprar dim-dim, uma espécie de picolé caseiro.

Também nessa instituição, começou a namorar Maria Helena que também não tinha pai nem mãe. Nesse período ela teve um tumor no útero e ficou estéril, o que era ruim, já que Marcos queria ter um filho cedo para poderem passear juntos. Eles brigavam muito, além de 
usarem muita droga juntos. Os funcionários da instituição pensavam que Marcos a influenciava negativamente. Ele a fez sofrer demais depois que terminaram o namoro porque foi ele quem "tirou a virgindade dela".

Um dia, um outro acolhido bateu em Marcos, deu um golpe que quase quebrou sua costela, já que ele treinava uma luta chamada jiu jitsu. Nesse dia, Marcos ficou muito angustiado. Então, ao invés de "furar" esse menino, ele cortou pela primeira vez seu braço, no pulso, com uma faca. E então aprendeu que, ao invés de descontar o que sentia nos outros, poderia descontar em si mesmo e tudo ficava normal. Depois repetiu essa ação várias vezes pois, segundo Marcos, quando se cortava, sentia uma sensação muito boa, de alívio, e, então, se cortou várias outras vezes. Se questionava porque tinha nascido se era somente para sofrer, já que o mundo não prestava. Então se cortava porque, no seu pensamento, tudo o que acontecia era culpa sua. Uma outra forma de aliviar a angústia que sentia era por meio do uso de drogas.

Aprendeu nesse abrigo que todo mundo somente olhava para ele quando acontecia alguma coisa séria e ruim. E as pessoas pensavam que ele fazia as coisas erradas porque ele era ruim, perverso e "do mal”. Mas, na verdade, ele não queria fazer o que fazia, ele só queria ser escutado, queria desabafar o "que tinha no peito", mas não conseguia. Quando alguém o ouvia, essa pessoa não era de confiança pois dizia aos outros o que ele tinha dito ou usava o que Marcos tinha falado, contra ele. Isso o deixava muito revoltado.

No momento em que os funcionários do abrigo conversavam com ele, Marcos somente via dó e pena no olhar deles em relação e ele. Nunca viu ninguém realmente interessado no que ele tinha a dizer. Muitos chegaram e comentavam: "nossa Marcos, que pena, sua história é muito triste", e isso era ruim de ouvir.

A coordenadora do local, Sílvia, gostava dele e um dia o convidou para passar as férias na casa dela. Mas quando chegou, ela começou a diferenciar Marcos dos filhos e dos 
sobrinhos dela. Ficou em torno de um mês e ele fazia coisas de criança na casa. Um dia quebrou um muro, sem querer, como frisou, mas como todos viram o estrago que fez, passaram a odiá-lo. Se fosse outra criança não iam fazer nada. Sílvia era sua madrinha, mas só de nome, porque ela o batizou na catequese e estava na igreja quando ele foi coroinha da igreja católica. Com o tempo, ele foi se apegando afetivamente a umas pessoas que diziam gostar dele, mas elas sempre o abandonavam em algum momento. Essa situação reforçou nele a descrença nas pessoas, sentimento que começou a ter quando ficou na primeira instituição. Um dia, lhe informaram que iria mudar de abrigo, sem maiores explicações. Mas Marcos sabia que era Sílvia que o queria longe dali. Ele saiu desse abrigo por causa dela.

\subsubsection{Instituição C: dos 15 aos 17 anos}

A terceira instituição foi uma dos piores em que ficou. Lá foi uma fase "cabulosa" de sua vida. Estava frágil, se envolveu muito fácil com drogas, como cola, tinner e maconha. Ficou depressivo. Mas viu que não era o mais inteligente, mas também não era o mais burro nem o mais forte. Como estratégia, se aproximou de um adolescente acolhido que era o melhor dentre os demais, buscando algum reconhecimento. Se alguém quisesse fazer algum mal a ele, esse que era o melhor e já era reconhecido, não iria deixar.

Depois de um tempo, os acolhidos mais velhos foram saindo da instituição, inclusive o adolescente de quem ele se aproximou também e ele se viu sozinho, somente com a sua história. Nessa instituição, os acolhidos ficavam “jogados”, e, nesse contexto, ele precisava se impor perante os outros meninos e meninas. Ao contar sua história para os colegas, conseguiu que eles ficassem do seu lado. E com isso, como os outros acolhidos eram frágeis, era fácil manipulá-los. Várias vezes, quando Marcos não concordava com alguma situação ocorrida na instituição, ele se juntava com os demais acolhidos e faziam rebelião. Tinha uma revolta e uma dor no peito, e lá pôde fazer muitas coisas ruins, como favorecer que os meninos 
brigassem entre si. Quando os seguranças batiam na cara dos acolhidos sem motivo, ele pensava que era injusto. Até sua mãe, que o tinha abandonado, não tinha batido nele, como um segurança poderia fazer isso? Então se juntava a outros acolhidos para baterem nos seguranças. Mas, ao mesmo tempo, era respeitado por esses seguranças.

Quando chegou na Instituição C, havia mães sociais que trabalhavam nas casas, cuidando das crianças e dos adolescentes, onde elas ficavam seis dias ininterruptos, com uma folga semanal. Mas depois de um tempo, por causa de uma reorganização institucional, elas foram substituídas por cuidadores sociais. As mães sociais falavam e cumprimentavam os acolhidos, se preocupavam como tinham passado o dia, eram quase uma família. Já os cuidadores, aprovados em concurso público, nem todos com experiência em instituições de acolhimento, trabalhavam em regime de plantão, ou seja, dia sim, dia não. Havia uma equipe para o dia e outra equipe para a noite. Mas o trabalho em plantão era ruim, pois um educador ensinava uma coisa e, de repente, chegava outro e dizia algo totalmente diferente, o que deixava Marcos indeciso. Com isso, perdeu a confiança em todos os da equipe.

Com a mudança das mães sociais para cuidadores sociais, Marcos organizou outra rebelião. Queria mostrar que os novos funcionários não conheciam nada da vida, nada do que eles haviam passado, sendo que alguns, inclusive, tinham quase sua idade e ainda queriam mandar nele. Gostaria de dizer que para estar ali, era preciso estar de coração, trabalhar de verdade e não "empurrar o trabalho com a barriga" o dia todo somente para ganhar um salário no final do mês, pois eles ganhavam o dinheiro deles e os acolhidos continuavam na mesma. Para Marcos, trabalhar com o coração não era focar na rotina, na entrega da alimentação aos acolhidos, dizendo que era hora de dormir, mas, ter dedicação na maneira como trabalha.

Os profissionais da instituição, quando queriam mostrar que os acolhidos estavam errados, ao invés de educar, oprimiam os meninos e as meninas. Quando alguma coisa errada acontecia, logo chamavam a polícia para intervir. E quando chegavam na delegacia, era claro 
que os policiais iriam ouvir os profissionais que eram concursados, e não os adolescentes de uma instituição de acolhimento. E Marcos, nesses casos, não tinha nada a fazer, a não ser entrar na delegacia de cabeça baixa e com as mãos para trás. Como usava chinelo e bermuda, já falavam que ele era "vagabundo".

Uma vez, enquanto brincava com uma bebezinha na instituição, a levantou e a deixou cair no chão. Foi sem querer, pois Marcos não tinha maldade com crianças, mas uma funcionária o levou para a delegacia e ele foi humilhado. Havia um policial que conhecia essa funcionária e que disse a Marcos que ele, ao invés de machucar "criancinhas", deveria estar trabalhando com uma enxada. Ele não podia falar nada senão, recebia um tapa na cara do policial. Esse policial completou que não sabia porque a Princesa Izabel tinha acabado com a escravidão no Brasil. Ele ficou quieto, até chorou, porque não podia falar nada. Mas se um dia ele chegasse a um policial e dissesse que ele era preto, com certeza iria preso, mas um policial podia ofendê-lo por ele ser negro que não acontecia nada.

Os educadores sociais, que trabalhavam nas casas em contato direto com os acolhidos, ao invés de se aproximarem e conversarem com os meninos e as meninas, se interessando pelo que havia acontecido ou pelo que estavam sentindo, iam "empurrando o trabalho com a barriga", não se importando com eles. Só se preocupavam em oferecer as refeições no horário preestabelecido. Alguns cuidadores se aproximavam de Marcos, como se estivessem interessados no que ele tinha a dizer quando, na verdade, queriam se aproximar dele para que Marcos dissesse aos demais acolhidos que aquele funcionário era legal, para não mexerem com ele. Usavam ele para ter mais segurança na instituição.

Com isso, Marcos criava sua própria regra na Instituição C. Mas para ele, havia muito cuidador social trabalhando no local para, na prática, não fazer nada, já que não se importavam com o que os acolhidos estavam passando ou sentindo. Diferente de quando havia as mães sociais, que era um porto seguro para os acolhidos. Os cuidadores sociais eram 
muito vingativas, não esqueciam e não perdoavam o que os acolhidos faziam de errado. Muitos vezes havia dois, três ou quatro cuidadores que se trancavam numa salinha que havia na casa, e os meninos ficavam fora, sem nenhum adulto por perto. Marcos até conseguiu se aproximar de alguns que se mostraram seus amigos, mas sabia que na verdade, faziam isso por obrigação, para o trabalho deles transcorrer tranquilamente. Para facilitar a comunicação entre os plantões dos cuidadores sociais, havia um livro no qual o que acontecia em cada plantão, era registrado por esses profissionais. Mas nem sempre os cuidadores escreviam os fatos como realmente haviam acontecido, e o cuidador do plantão seguinte pegava aquilo como verdade, sem ouvir a versão dos acolhidos. Não sabiam que cada um que lê um livro o faz de uma maneira, entende de um jeito, que pode ser diferente de outro que lê o mesmo conteúdo. Marcos tinha uma desavença com um adolescente que ficava na rua, próximo ao abrigo. Com isso, não ficava evadindo da instituição por um período. Então, para conseguir maconha, pedia para outros acolhidos irem buscar para ele.

Uma vez, colocaram fogo em uma das casas e logo pensaram que Marcos estava envolvido, mas dessa vez ele não estava, "por incrível que pareça". Mas ele e outros dois ou três adolescentes foram levados pela polícia e ficaram cumprindo medida socioeducativa de internação por 45 dias. Em geral era assim, era levado para a delegacia ou cumpria medida socioeducativa quando era inocente, e quando realmente fazia alguma coisa de errado, não conseguiam pegá-lo.

Nessa instituição havia uma adolescente chamada Zilma, que passou quatro meses em uma clínica de desintoxicação de drogas. Quando voltou, ela estava mais bonita e ela e Marcos começaram a namorar. Mas ele achava que ela era uma "vadia”, pois para ele, Zilma ficava com outros meninos também. Assim, Marcos também ficava com outras meninas. $\mathrm{O}$ lado bom de namorar com Zilma foi que ela mostrou muitas coisas da vida para ele. Mas ela não correspondia ao seu amor. E, por a amar tanto e querer muito ficar com ela, machucou-a 
fisicamente algumas vezes. Após um episódio no qual cortou os pulsos, depois de Zilma dizer que não queria mais namorar com ele e, somados ao uso constante de drogas, com grande ameaça de suicídio, Marcos ficou internado durante 40 dias numa clínica que trabalhava com saúde mental e dependência química. Após esse período, depois de retornar à instituição, tentou recuperar a liderança perante os demais acolhidos da instituição, mas foi difícil.

Numa sexta-feira à noite, cerca de 15 meninos e meninas estavam na quadra de esportes da instituição quando beberam três litros de "88" (um tipo de pinga) e uma garrafa de vinho de cinco litros. Marcos e Zilma, sua namorada, ficaram bêbados e tentaram ter relação sexual, mas vomitaram e não deu certo. Foram ao banheiro da casa, mas Marcos não quis tomar banho junto à Zilma, quis curtir a noite. Ao voltar para a quadra, viu o adolescente Lúcio com a boca sangrando, após uma briga com outro adolescente. Marcos foi tentar defendê-lo, mas outros adolescentes foram em cima dele com agressividade, num quiosque que havia no local. Seis meninos estavam com pedaços de madeira, e Fábio, um adolescente acolhido, bateu nele com um pedaço de pau. Marcos tentou correr quando Carlos o puxou pela calça e o segurou para Isael o ferir com algo cortante (que parecia ser um pedaço de vidro) no tórax, no lado esquerdo. Marcos correu mas, quando viu seu sangue, se apavorou. Ficou num canto e os profissionais da instituição chamaram a ambulância para socorrê-lo e a polícia para conter os demais adolescentes. Marcos passou a noite no hospital e pensou em resolver a desavença com os dois adolescentes que o feriram, depois, quando estivesse sóbrio.

Marcos não se arrependeu da maioria das coisas que fez nesse abrigo, com exceção de ter oprimido alguns meninos. Até poderia ter evitado algumas situações, se quisesse, porém, não tinha como fazer diferente porque era uma questão de sobrevivência. Mas nessa instituição, sempre respeitou os cuidadores sociais que ali trabalhavam. Ele tinha um prontuário, uma espécie de pasta onde ficavam os relatórios elaborados pelos funcionários. Esse prontuário era bem grande, mas para Marcos, a vida de uma pessoa não podia ser 
resumida ao que estava nos relatórios. No caso dele, constava que ele havia feito muita barbaridade, como se o tivessem escutado antes de escrever o que estava lá, mas não era o que acontecia. Os profissionais não liam para ele o conteúdo desses relatórios, mas ele sabia que tinha muita coisa ruim a seu respeito. Sabia porque o relatório ia de um abrigo para outro, e em algum momento, alguém comentava com ele sobre o que estava registrado.

Para ele, as psicólogas que o acompanhavam eram iguais a um robô, elas não se importavam para o que ele pensava e sempre falavam a mesma coisa, o que o deixava “doido". Elas falavam o que ele deveria fazer, como se dissessem algo que já tivessem gravado na "mente". Pediam para ele tomar decisões que para ele era difícil, às vezes não tinha saída, mas para elas era tudo muito simples. Um exemplo era quando falavam que ele deveria ir para a escola. Mas Marcos tinha dificuldade para aprender, ficava estressado e, quando ficava ouvindo o professor falar na sala de aula, sentia um aperto no peito que ele não sabia explicar direito o que era. Desde criança ele sentia isso e já não conseguia frequentar a escola. Então, por não ir para a escola, brigavam com ele. Outra situação que fazia as psicólogas brigarem com ele era quando ele evadia da instituição para ficar na rua. Queriam saber o motivo dele ficar evadindo, "como se fosse fácil ficar dentro de um abrigo, todo dia, o dia inteiro". Para mudar essa situação, Marcos pensava que as psicólogas poderiam ajudar os acolhidos a chegarem a alguma conclusão sobre o que era melhor para eles, que fosse algo que eles gostassem e quisessem. E, a partir daí, as psicólogas poderiam conversar com os acolhidos e mostrar, se fosse o caso, que aquela escolha não era uma boa opção, mostrando o motivo. Mas na realidade, as psicólogas queriam que os acolhidos concordassem com as escolhas delas, pois, caso contrário, eles estariam errados. 


\subsubsection{Casa Lar 1: 17 anos}

Para sua segurança, já que as ameaças de Carlos e Isael continuavam, Marcos foi transferido para a Casa Lar 1, unidade de acolhimento menor, ligada à administração da Instituição C. Era uma casa que ficava inserida na comunidade e que acolhia no máximo, 10 meninos e meninas. Foi ruim porque ficou afastado de pessoas que ele não queria, ao mesmo tempo em que foi bom porque ficou longe dos adolescentes que queriam matá-lo. Pela primeira vez, sentiu paz, tinha a sensação de que realmente tinha uma casa para morar, tinha um lar e tinha um armário para guardar suas coisas onde ninguém iria mexer. Mas como ele estava com 17 anos, via no olhar dos cuidadores sociais que eles não o queriam lá. Eles não verbalizavam isso com medo da reação de Marcos. Carlos e Isael, que feriram Marcos, tiveram que cumprir três anos de medida socioeducativa na internação. E então, como os dois que o ameaçavam saíram do abrigo, Marcos retornou para o abrigo institucional da Instituição C.

\subsubsection{Instituição C: 17 anos}

Um dia, logo depois de acordar, o chamaram para conversar e deram a ele duas opções: ou ficar três anos cumprindo medida socioeducativa de internação, que era em regime fechado, pelo o que ele já tinha feito de errado, ou ficar internado no hospital psiquiátrico, o mesmo que passou uma noite quando cortou os pulsos na instituição. Ele questionou se não tinha outra opção, mas os funcionários disseram que não. Chegou a pensar que uma terceira opção era sair correndo e ir para a rua, mas não teve como fazer isso. Assim, ele ficou nervoso, "virou um monstro" e logo os seguranças o seguraram. Primeiro, foram para o hospital psiquiátrico, mas como o médico do hospital viu que não havia motivo para internálo, o levaram para a delegacia. Lá, disseram que ele tinha ameaçado a equipe da instituição, 
sendo então levado para cumprir medida de internação. O fato de "puxar cadeia" sem dever o deixou estressado.

Havia uma psicóloga no local onde foi cumprir medida de internação de quem Marcos gostava, pois ela acreditou e confiou nele. Conseguiu uma vaga para ele ir para uma clínica de recuperação de drogas, mas o lugar era como uma prisão, ficava numa área rural, e Marcos saiu de lá. Para a sociedade, todos os que estão presos são "vagabundos". Para ele, ele era somente uma pessoa que não sabia se entender nem entender as outras pessoas. Ele só queria viver, sem prejudicar ninguém, nem a ele mesmo. Mas não sabia como fazer. O momento mais marcante no ano de 2010 foi ter engravidado Zilma.

\subsubsection{Instituição D: 17 anos}

Essa instituição na qual ficou acolhido também era "cabulosa", como a anterior. Lá acolhiam meninos e meninas dos 12 aos 24 anos. Cursou a $4^{\text {a }}$ série em uma escola para meninos e meninas em situação de rua, e também usava drogas para esquecer o que era ruim. Passou a perceber que existiam outras formas de pensar, que não só a sua. Antes, ou a pessoa pensava como ele ou tinha que "se sustentar", ou seja, aguentar as consequências de pensar diferente dele. Mas havia aprendido a parar para pensar antes de agir. Ainda sentia uma agonia, uma dor no peito. Tinha medo de planejar as coisas para sua vida e elas não darem certo. Gostaria muito de voltar a namorar com Zilma, que tinha ficado na Instituição C, pois ela era uma pessoa especial e que merecia ser feliz. Quando Marcos saiu da Instituição C, Zilma havia ficado grávida dele e, enquanto estava na Instituição D, seu filho nasceu. Tinha vontade de se casar com ela e a fazer feliz. Nessa instituição ele se identificou mais do que a anteriores, pois as pessoas eram maravilhosas. Antes, não queria mudar de vida, mas depois de entrar nessa instituição, passou a querer outras coisas. 
Em relação às drogas, usava para fugir da depressão, mas depois do efeito delas, a depressão voltava em dobro. O nome que ele e os demais acolhidos davam para maconha era "salva nós" e para o crack, "alkaida". O crack atrapalhava a pessoa de forma geral. Antes, ele discriminava o crack mas essa droga era muito forte, era melhor do que ter relação sexual. $\mathrm{O}$ problema é que logo depois de usá-lo, vinha o desespero e a vontade de conseguir mais crack. Nesse sentido, o usuário buscava no próprio corpo e em tudo o que era de valor, o que podia ser vendido para conseguir mais crack, ficando cada vez mais egoísta. Quanto mais se tinha, mais fumava. As pessoas usavam crack pelas situações que já passaram, mas ficavam feias, com os ossos aparecendo e com baixa autoestima.

Ainda usava maconha de vez em quando, assim como cheirava tinner e fumava cigarro. Quando usou crack, sentiu uma sensação muito boa na hora, mas depois vomitou muito. Estava ficando muito "destruído" e não se reconhecia no espelho. Olhou para como as pessoas que usavam crack ficavam e, por ser uma pessoa inteligente, substituiu por maconha, afinal, tinha um filho para criar. Depois que parou de usar crack, os meninos da instituição começaram a ficar com raiva dele porque as meninas passaram a olhar mais para Marcos do que para eles. Então, todo dia tinha um acolhido que queria matá-lo.

Mas um dia, depois de Marcos e dois colegas da instituição usaram droga o dia todo, na rodoviária da cidade, esses dois colegas mataram um homem porque uma quantia de droga havia sumido e eles acharam que o rapaz, que estava ali perto, havia pegado. Depois desse ocorrido, os dois ficaram pressionando Marcos para assumir a autoria do crime, mas ele disse que não iria fazer isso. Foi muito ruim ver essa pessoa morrer, de forma violenta, levando pedrada na cabeça. Passou noites sem dormir.

Valteir, seu amigo, apresentou-lhe "como as coisas são" e como ganhar dinheiro fazendo programa em locais homossexuais. Marcos ficou especializado em ganhar dinheiro fácil. Na hora em que mantinha relação sexual com outro homem gostava, mas não sabia 
porque. As pessoas o usavam e quando ele "estava só o resto", diziam que ele podia ir embora. Essa situação lembrava a dor que sentia na infância. Recebia $R \$ 10,00$ ou $R \$ 20,00$ para fazer sexo oral. Por sexo anal, $\mathrm{R} \$ 60,00$, com lubrificante. Às vezes Marcos telefonava para algum homem com quem já tinha feito programa e essa pessoa o mandava buscar de táxi. Numa noite fazia dois ou três programas, chegando a ganhar $\mathrm{R} \$ 100,00$ por noite. Depois de um tempo ele parou de fazer isso.

Valteir era muito errado, pois ganhava dinheiro às custas dos outros. Ele "entrava na mente" de Marcos, "estressando-o" para roubar e pedir. Então, roubava à noite e dividia o que conseguia com Valteir. Marcos queria ter dinheiro para ter poder. Mas para ser feliz, gostaria de ter uma casa, um trabalho, uma família gigante, mas que tivesse alguma convivência entre si. Tinha vontade de ser mecânico de carro. Já pensou em ser veterinário, pois cuidar dos animais o fazia lembrar dos momentos que passou na primeira instituição, junto aos animais. Esses eram momentos de tranquilidade. Nessa instituição ficou mais calmo, mais tranquilo. Tentava dizer o que passou para as outras pessoas. Estava descobrindo coisas da vida. Podia escolher usar crack ou se prostituir, mas não era mais preciso. Assim, como parou de se prostituir, nos finais de semana ficava na instituição, sem dinheiro, e isso era ruim. Ele precisava estudar e se preparar para ser aprovado numa seleção em que receberia uma bolsa de estudos para ter direito a aulas regulares num turno, e no outro, cursos profissionalizantes. Mas, ao mesmo tempo, como era discriminado na escola quando criança, tinha medo de passar por isso de novo. Precisava colocar a "cabeça no lugar", sabia que ainda estava em tempo para organizar sua vida. O que queria mesmo é ter uma casa, mesmo alugada, e ver o filho nos finais de semana. Gostava de dinheiro e se imaginava trabalhando. Zilma, sua exnamorada e mãe de seu filho Pedro, já havia conseguido um trabalho. Pedia a Deus para dar força aos seus inimigos para que eles vissem sua vitória. Sabia que Carlos e Isael, os que o feriram na Instituição C, iriam sair da internação e, assim, iriam querer se vingar dele. Retirou 
seu documento de identificação e se alistou para prestar serviço militar, obrigatório na idade dele, o que o fez se incluir mais na sociedade. Só faltou solicitar outro documento de identificação, também necessário, mas estava tranquilo em relação a isso.

Depois de um tempo, o pessoal da Instituição D, tanto a equipe como os demais acolhidos, ficavam desacreditando dele, o que o fazia se "estressar". Se fosse antes, daria facada ou predada, mas naquele momento de vida não ligava, mas era muita humilhação. Se sentia a pessoa mais covarde da face da terra, mas ao mesmo tempo, sabia que não era. Os outros queriam que ele saísse para a rua, mas como ele não ia mais, o ficavam humilhando. Ao dizer a Marcos que ele estava com medo, as pessoas queriam o deixar inseguro. Ele estava cansado de ficar no abrigo, se sentia abandonado. Estava com cara de "drogado, de abandonado e de marginal". Pelas roupas que usava, que era camiseta, bermuda, chinelo e boné, as pessoas ficavam olhando-o na rua, com desprezo.

$\mathrm{Na}$ escola, onde somente frequentavam os acolhidos daquela instituição e era especializada em trabalhar com meninos e meninas em situação de rua, sentia a mesma coisa de quando era criança e ia para a escola. Enquanto estava nessa instituição, ia para a aula sem comer antes, pois não conseguia, mas sentia enjoo na aula e não conseguia se concentrar. Com fome, ficava estressado e xingava os professores, mas depois se arrependia, aí ficava com vergonha. Percebia que alguns alunos recebiam mais atenção e eram mais respeitados do que outros pelos professores. Nessa escola, o tratavam como "doido", mas queria ser "adulado". Ao mesmo tempo, se considerava um bom aluno, participava das aulas, porém não compreendia direito a matéria. Estava cansado de tudo o que viveu, sentia-se cobaia do mundo. Muitas vezes, por medo de uma situação diferente dar errado, não tentava fazer algo novo. Porém, atuando no tráfico de drogas, começou a manter seu respeito perante os demais. Vendia droga "de graça" pois, quando os usuários choravam, ele adiantava uma quantia de droga para pagarem depois. Não ganhava nada, estava no tráfico só pela "adrenalina". Sabia 
que iria mudar sua história pois já havia passado por muita coisa. Aprendeu a controlar mais suas emoções, parou de bater nas outras pessoas. Iria honrar quem ele era. Era pai, mas não sustentava seu filho, não contribuía financeiramente com sua criação, e isso era ruim. Sabia que ser pai era ser "o cabeça" da família. Gostaria de dizer para as mães darem valor nos seus filhos e os filhos darem valor nas suas mães. Era ruim crescer sozinho. Era ruim gostar mais dos outros do que os outros dele. Queria olhar e querer o bem das pessoas, mas também gostaria de ver isso nas pessoas com relação a ele. Mas as pessoas sempre queriam seu mal, então Marcos era egoísta e se defendia antes delas se aproximarem. Essas pessoas somente olhavam para a aparência e não para o que ele sentia. Elas não sabiam o que o levou a ser daquele jeito. Algumas coisas justificavam outras. O importante era não julgar, mas tentar respeitar o outro.

Depois de um tempo na Instituição D, Marcos foi aprovado na seleção para a qual estava se preparando e passou a receber uma bolsa de estudos de $\mathrm{R} \$ 400,00$ para estudar pela manhã e fazer cursos profissionalizantes a tarde. Vale ressaltar que esse espaço recebia diversos alunos da comunidade, não só meninos em situação de rua. Percebia isso como uma boa oportunidade. As coisas estavam se encaminhando, dando certo. Estava mais seguro, "arrumou sabedoria". Dizia que podiam lhe tirar tudo, menos sua sabedoria. Depois que foi aprovado na seleção, passou a perceber que sua autoestima aumentou, pensou que sua vida iria mudar.

Segundo ele, tinha como qualidade ser extrovertido e fazer amizade com facilidade. Gostava de pintar e de desenhar, também de jogar basquete e fazer natação. Era bom em negociação porque conseguia muitas coisas que desejava. Mas um tempo depois, a pesquisadora do presente estudo, disse a Marcos que havia encontrado sua família. Nessa época, ela havia começado a trabalhar com Marcos sua história de vida, iniciando seu estudos de doutorado. Quando ficou sabendo da notícia, primeiro ele "tomou um choque", pois essa 
era uma sensação diferente, já que nunca havia tido ninguém. Depois pensou que poderia ser algo especial. Mas Marcos aproveitou que a pesquisadora havia encontrado sua família para ficar com eles e distante das pessoas que conhecia pois, os dois jovens que mataram um rapaz, na presença de Marcos, queriam que ele assumisse no lugar deles. Mas ele não tinha feito nada e não ia assumir um crime de outra pessoa. Então, saiu da instituição onde estava e do projeto onde recebia bolsa de estudos, com medo dos dois o matarem.

\subsubsection{Inclusão da família de origem: dos 17 aos 18 anos}

Marcos pensava que sua família iria cuidar dele e que as coisas iriam mudar, mas na verdade não mudou nada, eles não o ajudaram em nada. Sua mãe já havia morrido e ele, como único herdeiro, tinha direito a receber uma indenização. Contaram que ela estava em um caminhão e ela se jogou, quando caiu e acabou morrendo. Mas Marcos não acreditava que sua mãe tinha se jogado, tinha certeza de que foi seu pai que a empurrou. Ele sabia disso porque sua avó, por parte de mãe, odiava seu pai e não queria que ele conhecesse os familiares por parte de pai. Mas, com a ajuda de uma tia materna, Marcos se encontrou com uma tia paterna. Essa última disse que seu pai morava longe e, como ele viajava muito com um caminhão, ele não iria poder se encontrar com ele. Nesse momento, Marcos achou muita coincidência sua mãe ter morrido após cair de um caminhão e seu pai trabalhar dirigindo um caminhão. Seu pai tinha muito ciúme de sua mãe porque ela era muito bonita e se vestia bem.

Um situação que o deixou indignado foi o fato do avô materno ter engravidado a própria filha. E essa tia tinha ficado "louca" e não sabiam o paradeiro dela. Provavelmente ela estava na rua. Marcos gostaria de ser especial na sua família, de ser amado de verdade, mas na verdade eles o queriam encontrar para que ele recebesse a indenização da morte da sua mãe, já que ninguém poderia receber em seu lugar. Muitos tios falavam para ele que estavam a sua procura pois assim que completasse 18 anos, ele não teria mais o direito de receber esse valor. 
Diziam também que o avô não tratava bem as pessoas, mas que o recebia para passar alguns momentos em sua casa porque, com certeza, também queria uma parte do dinheiro. Ele ficou morando na casa de um tio, mas como o dinheiro começou a demorar para sair, sua família começou a tratá-lo diferente. Seu tio e esposa colocavam para ele as regras da casa e dividiam as tarefas, mas Marcos não seguia o que era combinado. E, nas discussões, dizia que via que eles não gostavam dele, só queriam humilhá-lo. Sua avó mudou de ideia e disse que não podia levá-lo para morar com ela, dizendo que ele brigava muito com a namorada Zilma. Então, Marcos decidiu sair da casa do tio, onde estava morando.

\subsubsection{Quando morou sozinho: 19 anos}

Quando saiu da casa do tio, com o dinheiro da indenização, alugou uma casa ao lado da casa do tio, para tentar manter contato com sua família, mas na verdade só recebeu desprezo por parte deles. Considera que sua família mesmo são os moradores de rua. Depois que saiu de perto da família, foi morar em outro local, perto do local onde a namorada Zilma estava acolhida, com seu filho Pedro. Alugou um quarto, mas não conseguia morar sozinho. Passou muita fome, não cozinhou, não lavou roupa, nunca arrumou a casa e nunca se preocupou com isso. Entrou em depressão. Um dia brigou com Zilma e ela o denunciou à polícia. Marcos ficou preso na delegacia por uma noite mas, com o que ainda restava do valor recebido da indenização (recebeu o total de R $\$ 13.500,00$ ), pagou a fiança e foi liberado.

Desse local foi para a Instituição E que acolhia meninos e meninas em situação de rua, levado por um educador e pela coordenadora desse local. Marcos já os conhecia da Instituição D, pois trabalharam no local na época em que ficou acolhido nesse abrigo. Então, doou os móveis que havia comprado para Zilma, quando saiu do quarto alugado. 


\subsubsection{Instituição E: 19 anos}

$\mathrm{Na}$ Instituição E, "se recuperou" das drogas, somente continuou a usar maconha. Havia parado de usar crack, não queria isso para sua vida. Depois de um tempo, os profissionais da instituição juntaram um grupo de jovens para morarem numa casa, numa espécie de república, onde dividiriam as despesas da moradia. Alguns já trabalhavam e obtinham alguma renda financeira.

\subsubsection{República com outros jovens: 19 anos}

Na república tudo deu errado porque cada um dos jovens pensava de um jeito, cada um queria fazer as coisas a sua própria maneira. Como alguns usavam crack, vendiam alguns objetos da casa para conseguirem a droga. Assim, alguns policiais filmaram a casa e sua movimentação e pensaram que a casa era de "vagabundo". Mas na verdade eles somente se vestiam como "vagabundo", pois todos queriam mudar de vida. Com isso, várias vezes a polícia invadiu a casa para buscar drogas e "marcaram" Marcos. Um dia, um grupo de policiais forjou que Marcos estava numa situação de tráfico de drogas e ele foi preso, inocentemente.

\subsubsection{Sistema prisional: 19 anos}

Depois que conheceu o sistema prisional, Marcos mudou. Quando alguém vai preso sem motivo, fica muito revoltado. Mas ele se apegou a Deus e viu que sempre há um motivo para alguma coisa acontecer, e se Marcos estava preso, é porque Deus o tinha livrado de alguma coisa ruim. Talvez livrado da morte, já que um amigo dele morreu envenenado enquanto ele estava preso. Ficar preso foi ruim e foi bom ao mesmo tempo, pois ele aprendeu várias coisas. Aprendeu a ver o mundo de outro jeito, ficou com mais vontade de trabalhar, de 
ser "alguém" na vida e mostrar isso para os que não acreditavam nele. Iria mostrar para Zilma, que desistiu dele, que podia ser "alguém" e ela iria se arrepender de o ter deixado. Ser alguém era ser trabalhador e adquirir as coisas de forma digna. Para isso não precisava ser rico, somente ter uma casa, um carro e uma família. Na prisão acontecia culto de uma igreja todo dia, e se alguém não quisesse seguir o ritmo da cadeia, ou seja, fazer coisas ruins, precisava estar com Deus. Os outros presos não faziam nada de mal com quem aceitasse Deus. Mas Marcos não se adaptou totalmente aos encontros da igreja, frequentando-os algumas vezes.

Quando dormia, ficava com medo e tinha que ficar em estado de alerta o tempo todo porque, a qualquer hora, a situação podia mudar e ser transferido para o "seguro". Esse era um local onde pessoas ameaçadas ficavam um tempo, até que a ameaça cessasse. Mas nessa situação, o preso era visto como uma "piada" pelos outros presos e pelos policiais, já que não tinha conseguido se defender sozinho. E com isso, não era mais considerado pelos outros. Havia um homem mais velho que Marcos, que ainda iria ficar preso muito tempo, que queria abusar sexualmente dele. Mas não deu certo, pois Marcos gritou que ele era "jack", gíria usada para designar estupradores, e os demais presos bateram nesse homem, evitando que Marcos fosse violentado. Depois desse episódio, o tal homem ficou em um outro lugar, separado de Marcos. Enquanto estava preso, ocorreu a audiência sobre o homicídio com os dois jovens que queriam que Marcos assumisse a autoria do crime de homicídio. Ele não planejava falar o que sabia, mas como o juiz o ameaçou, dizendo que ele iria ficar mais tempo preso se não falasse o que tinha realmente acontecido, Marcos contou que os dois mataram um homem. Quando contou, os dois jovens foram retirados da sala de audiência. Para Marcos não é certo matar um pai de família.

Era respeitado na prisão porque não era "jack”. Esses apanhavam muito, bem como bandido que roubava coisas de outros bandidos. Os estupradores e pedófilos ou morriam na 
prisão, ou eram estuprados "em dobro" por outros presos. Outros que também apanhavam eram os que batiam na própria mãe e o que xingava a mãe dos outros. Já traficante era respeitado pelos demais. Os que iam preso por bater na mulher, apanhavam de outros presos, mas se a mulher tivesse armado alguma coisa contra o homem, e esse tivesse batido nela para se defender, não havia problema, porque ela merecia apanhar. O homem tinha o direito de bater na mulher nesse caso. Marcos conheceu um homem que tinha matado a própria mãe, outro, a prima. Esse último fez isso porque ela o chamou de "corno", ou seja, disse que ele tinha sido traído pela mulher. Esses não eram respeitados no sistema prisional.

$\mathrm{Na}$ primeira cela em que ficou havia 30 presos, com 10 camas disponíveis. Era a triagem. Para dormir na cama, era preciso pagar $\mathrm{R} \$ 100,00$ para o dono da cama, que era um outro preso. Para dormir no chão, era R\$ 50,00. Não tinha como não pagar. Então, para Marcos pagar o que devia, fazia faxina e lavava roupa dos companheiros de cela. Para cada camiseta recebia $\mathrm{R} \$ 1,00$ e para cada bermuda, $\mathrm{R} \$$ 0,50. Depois de 10 dias na triagem, onde não recebeu nem colchão, nem cobertor, foi para outra cela, numa das alas do complexo penitenciário. Marcos pensava que no início eles não ofereciam colchão nem cobertor para que o preso, depois de receber esses itens, pudesse dar valor e ficar quieto. Na segunda cela, tinha direito a banho de sol e era mais assistido pelos policiais. Falavam que também tinham direito a ir ao médico, mas era tudo mentira, pois o interno quase morria na cela e ninguém ia socorrer. O preso só ia para o atendimento médico quando a família pedia para ele receber esse tipo de assistência.

Os presos eram divididos nas alas do sistema penitenciário de acordo com seu perfil. Traficante ficava com outros traficantes. A situação financeira também era um critério para dividir os internos. Se um homem era preso com arma de fogo calibre 38 ou 40, significava que tinha dinheiro, pois essas armas eram caras. Essas pessoas recebiam visitas e, por estarem 
em uma situação melhor, humilhavam os demais. Por esse motivo, ficavam em alas separadas, com outros que possuíam a mesma situação financeira e familiar.

A primeira ala em que Marcos ficou, depois da triagem, foi a ala A. Mas como ele não se adaptou bem, mudaram-no de lugar. Ele se sentiu mal nesse local porque não estava com pessoas que também tiveram uma vida sofrida e que eram traficantes porque precisavam, como ele. Seus companheiros de cela, na ala A, eram traficante não por necessidade, mas por opção. Eles gostavam da sensação de vender drogas. Então, foi transferido para a ala C, onde havia traficantes pobres e, para Marcos, os pobres eram mais humildes. Esses o receberam bem, foi a melhor cela que ele ficou, pois todos eram da "favela". Não bem uma favela, porque na cidade não existia favela, mas todos moravam na periferia. Marcos chegou nesse local depressivo, já que estava ali por um crime que não havia cometido, mas os colegas falaram para ele ficar tranquilo pois iria sair logo dali.

Também havia a ala dos estudantes. Se o preso tivesse o Ensino Superior ou o Médio, ficava separado. Se tivesse um bom comportamento, o advogado da pessoa também pedia para o preso ir para a ala dos estudantes, mesmo se ele não tivesse muitos anos de estudo. E nessa ala, tudo era mais tranquilo, pois havia menos pessoas por cela. $\mathrm{Na}$ ala $\mathrm{C}$, Marcos também lavava roupas dos companheiros de cela. Mas se os policiais descobrissem que um preso lavava roupas de outros presos, era levado para o castigo. Ficava 10 dias isolado, sem fumar, como se estivesse na solitária. Assim, ele lavava roupas dos outros, menos cueca, mas era humilhado por isso. Ele era o único que lavava roupa, e ainda limpava a cela toda. Mas com o tempo fazendo esse serviço, foi ganhando respeito. Mas mesmo com esse trabalho, Marcos dormia no chão, pois era mais barato e queria economizar dinheiro. Recebia R\$30,00 a cada 15 dias, em dinheiro, pelo trabalho que fazia.

Marcos fazia uma espécie de promoção para os colegas: ao invés de $\mathrm{R} \$ 1,00$, cobrava $\mathrm{R} \$ 0,50$ para lavar uma camiseta, e às vezes lavava alguma peça de graça, como meias. Ao 
verem a humildade dele, os colegas passaram a respeitá-lo mais. Um dia contou sua história a eles e, depois disso, viram como sua história era triste e como ele sempre tentava sair do crime mas nunca conseguia. Viram que ele "nasceu no crime, no berço do crime", mas como ele era humilde, passaram a ajudá-lo. Disse aos companheiros que havia nascido no crime, pois nasceu pobre, destinado a ser o pior "vagabundo", diferentemente de outros que estavam presos por motivos simples. Havia um, por exemplo, que matou uma mulher que frequentava uma igreja protestante, somente porque ela o chamou de "corno". Com isso, iria ficar muitos anos preso.

Contrariamente aos funcionários da Instituição B, que ficavam com pena dele, os colegas de cela viam alguma esperança em Marcos pois, com sua história, poderia ser o pior assassino que existia, o que ele não era. Não tinha matado ninguém até aquele momento. Os colegas se admiravam que ele não expressava a raiva e o ódio que sentia, mas Marcos comentava que tinha fé em Deus e que o tempo bom iria chegar para ele também. Para Marcos, uma pessoa pobre tinha mais chances de seguir a vida do crime, mas ser pobre não era um defeito. O defeito estava em não receber assistência na vida, em não ter ninguém que estivesse ao seu lado. Era estar sozinho, não ter ninguém que perguntasse como o foi o dia na escola, ninguém para desabafar ou falar o que aconteceu durante o dia.

Marcos encontrou um "playboy" que estava preso pela primeira vez, e o ajudou, já que Marcos era mais "vivido". Disse para o rapaz ter calma e deu uns conselhos para ele. Esse rapaz estava lá por um “motivo simples”. Era possível um preso ter um padrinho na prisão, no caso, outro preso que recebia visita, e Marcos tinha um. Ele o protegia e dividia o que tinha com ele, como comida e cigarro. Cada cigarro custava $\mathrm{R} \$ 1,00$, mas Marcos vendia umas bolinhas de trevo, que era o cigarro sem ser enrolado, por R\$1,00 também. Um saco de trevo custava $\mathrm{R} \$ 10,00$. 
Havia uma pessoa, o senhor Diego, um policial, que agia como se fosse "o dono da cadeia”. Ele era muito agressivo e desmaiava as pessoas, preso ou policial. Ele fazia algo com os presos que chamava "strike", e acontecia quando eles faziam alguma coisa errada ou não seguiam o procedimento do sistema. Tal ação consistia em deixar o preso no chão, com a cabeça entre as pernas, só de cueca. Se não fizesse isso, iria para o castigo. Se ocorresse uma briga entre os internos, os dois iriam para o castigo, pois o senhor Diego não queria saber quem havia começado a briga, castigava ambos.

Dia de visita dos familiares era sagrado, não podia brigar, se não, morria. Marcos já viu gente morrer por isso. E se um preso cumprimentasse uma visita de outro preso, ficava "marcado". Havia também um interno que era muito magro e que tinha algum tipo de doença mental. Todos o excluíam, mas Marcos se aproximou dele e ofereceu sua cama para revezarem. Na cadeia, nunca se está sozinho. Mas depois de um tempo, esse rapaz começou a receber visita e, com isso, começou a ser valorizado pelos colegas. Já Marcos valorizou o rapaz antes de tudo, sem esperar receber nada em troca. Só esperava que Deus visse sua ação e o recompensasse, livrando-o da morte.

Com a experiência da prisão, Marcos viu que a vida era fútil, pois um dia está vivo e pode não estar no outro. A vida não valia nada, só valia diante de Deus. Viu no sistema prisional que é necessário ter dinheiro para tudo. A pessoa vale pelo que tem. Se não tem nada, é um nada, não passa de um "merda".

\subsubsection{Casa de uma ex-educadora social: 19 anos}

Depois de dois meses e meio, Marcos foi liberado do sistema prisional pois foi considerado inocente. Era noite e ele foi andando da prisão até a rodoviária da cidade. Mesmo acostumado a dormir na rua, aquela noite foi diferente, pois ele estava com medo de tudo, como quando dormia na prisão. Encontrou na rodoviária um rapaz que ele havia encontrado 
na prisão, mas esse jovem tinha voltado a usar muita droga e estava bem mais magro e Marcos quase não o reconheceu. Marcos estava vendo o que a droga fazia com a pessoa.

Para conseguir droga na região da rodoviária era fácil. Um cigarro de maconha custava $\mathrm{R} \$ 5,00$, e se comprasse três cigarros de maconha, teria que pagar $\mathrm{R} \$ 5,00$. Já o crack, custava $\mathrm{R} \$ 10,00$ a pedra. Depois de fumar crack, a pessoa queria fumar outra pedra e, quando não tinha dinheiro, roubava.

Ao sair da prisão, passou a ver as coisas de forma diferente, não entendia as pessoas direito. Estava com medo de tudo e de todos e precisou de aproximadamente uma semana para se recompor novamente na sociedade. Encontrou as pessoas que o denunciaram injustamente, na rua. Elas tremeram de medo quando o encontraram, mas Marcos resolveu não se vingar, disse a elas que não iria fazer nada. Elas iriam pagar o que fizeram para Deus. Depois foi até trabalhar uns dias com uma dessas pessoas. Marcos também se encontrou com os dois jovens com quem estava quando ocorreu um homicídio. Eles ameaçaram matá-lo na rua por ter entregado eles para a polícia. Então, ficava vigiando o tempo todo porque sabia que eles podiam pedir para outra pessoa fazer o serviço para eles e matar Marcos.

Umas pessoas que trabalharam na Instituição D e, depois, na Instituição E, aceitaram acolher Marcos na casa deles, como se ele fosse da família, pelo tempo que ele precisasse. Foi legal porque elas sabiam que ele nunca tinha tido ninguém na vida. Como a família de origem de Marcos não o aceitava, essas outras pessoas o acolheram porque ele sempre as respeitou. Marcos ainda tinha um valor da indenização que havia recebido da morte da sua mãe, aproximadamente R\$3.200,00. Emprestou esse dinheiro para as pessoas que o acolheram, que pagavam de volta $\mathrm{R} \$ 100,00$ ao mês. A casa onde passou a morar estava em reforma e Marcos ajudava na mão-de-obra, recebendo um valor por isso.

De vez em quando, quando os pensamentos ficavam muito pesados, ia para a igreja. Por pensamento pesado, referiu-se à vontade de desistir de ter uma vida mais tranquila e ir 
atrás de quem o denunciou, fazendo-os ir para a prisão, ou então esfaqueá-los e dar uns tiros neles. Mas na igreja, eles falavam o tempo todo que Deus estava livrando os que estavam ali, da morte, e isso impressionava um pouco Marcos. Um dia, uma mulher apontou para ele e disse que Deus o estava livrando da morte naquele momento. Para ele, ela o apontou pois ele estava com uma aparência de marginal, já que era pobre, negro, morava na periferia e era o único daquele jeito na igreja.

Os que moravam na periferia da cidade morriam mais fácil, mas Marcos aprendeu a se proteger. Como ele cresceu em abrigos, ele tinha que se proteger o tempo todo mas, para isso, precisou machucar algumas pessoas. E esses que ele havia machucado no caminho da vida não iam deixar isso "barato", porque ele também não deixaria. E ficava preocupado porque queria mudar de vida, já que tinha um filho. Mas e as pessoas que ele tinha batido? Ficou pensando nas pessoas que ele deu paulada, nas que foram expulsas do abrigo por sua causa, que foram para rua e passaram a usar mais crack. Não sabia como essas pessoas estavam naquele momento.

Antes tinha muito medo do sistema prisional, mas depois que conheceu como funcionava, não tinha mais medo de voltar lá. Mas queria voltar por uma coisa que tivesse feito, não por algo que não fez, como aconteceu. Como conseguiu ser respeitado na prisão por meio do trabalho, lavando roupa e limpando a cela, viu que essa é uma maneira de conseguir ser considerado. Por isso, depois que foi liberado, trabalhava "sem parar". E os "bandidos" da rua o viam e ficavam admirados pelo seu esforço, e pensavam que não conseguiam ser fortes como Marcos, que não era bandido e se dedicava ao trabalho. A força da pessoa estava "na mente", e Marcos passou a valorizar o trabalho. Tinha que trabalhar e "correr atrás", mas existia alguma coisa no seu caminho que não o deixava continuar nesse trajeto, sempre acontecia alguma coisa de errado, algo que o puxava para um outro caminho. Conseguir trabalho era fácil, o difícil era permanecer no trabalho pois o chefe sempre humilhava e o 
mandava fazer várias coisas. "Tinha que ter cabeça para ficar". Com isso, a pessoa saía do emprego e escolhia ganhar as coisas de um jeito mais fácil, fazendo coisas ilícitas. Mas tinha algo importante: o que vinha fácil, também ia fácil. Se ele roubasse um carro, somente era necessário colocar uma arma na cara do motorista e entrar no carro. Depois, vendia o carro, fazia outras coisas e, quando percebia, não estava com nada. "Aqui se faz, aqui se paga".

Existem dois tipos de consideração que as pessoas podem ter em relação a uma pessoa. "Um não faz mal e o outro qualquer dia se vira contra a pessoa e aí, ela está fora". Antes era considerado pelos colegas por vender drogas, mas não queria mais ir por esse caminho. Antes fazia isso pela adrenalina que sentia na hora. Mas estava num momento de buscar respeito a partir do trabalho. Disse que não sentia mais a adrenalina de antes, e ela não fazia falta, já que fazia outras coisas. Mas ainda naquela época, quando Marcos ia para a rodoviária, onde vendia drogas anteriormente, chegava usuário pedindo droga para ele.

Ainda sentia uma dor no peito, mas ficava um pouco perdido com isso. Às vezes ficava com raiva, com vontade de falar que as pessoas com quem morava naquele momento, na verdade, não se importavam com ele, mas ao mesmo tempo não conseguia expressar no que eles estavam interessados. Mas, mesmo assim, se sentia melhor com estranhos do que com sua família.

$\mathrm{Na}$ casa onde ele estava, se sentia bem porque as pessoas já tinham trabalhado com meninos de rua e conheciam o sofrimento de quem não tinha uma mãe ou um pai. Sabiam como era ser sozinho no mundo, o que era ninguém querer saber o que se sentia, ninguém se preocupar se levou um tiro ou uma facada. Quem trabalhava com meninos de rua tinha alguma identificação com esse público, tinha algum motivo, mas não sabia bem qual. Mesmo não tenho morado muito tempo na rua, Marcos se sentia fazendo parte desse grupo e o que os unia era o sentimento de abandono, o fato de ninguém acreditar mais neles. 
Ele queria ficar longe de pessoas de instituições de acolhimento, não porque as estava discriminando, mas porque queria chegar a um outro ponto, viver uma outra vida, mudar sua trajetória. Gostaria de ver o filho diariamente e ensinar coisas para ele. Gostaria de contar sua história e mostrar que o caminho que ele seguiu não deu certo, para ele seguir outro caminho. E, com isso, deixar o filho fazer sua escolha a partir desse ponto. Não foi o que fizeram com ele, não mostraram uma outra opção para que pudesse escolher.

Em um final de semana, foi para a localidade onde o tio, com quem ele morou um tempo, morava. Esse tio o convidou para passarem o final de semana juntos e, então, foram para um outro lugar, na casa da sogra do tio. Dois tios por parte de mãe estavam lá, um deles era parecido com seu avô. Tirou algumas fotos no celular. Eles chamaram Marcos para jogar futebol com eles, mas ele não aceitou porque o campo era de terra e eles jogavam empurrando os demais jogadores. Ele não estava acostumado a jogar em campo de terra e como sabia que não ia aceitar que alguém o empurrasse em campo, que iria revidar e que seus tios iriam se envolver na confusão, decidiu não jogar. Seu tio havia trocado de carro. Dormiu na casa com a família e voltou para onde estava morando no dia seguinte.

O final de semana que passou com a família foi legal, reviu quase todos, menos sua avó. Disseram que ela ficava sonhando com ele. Marcos deu seu número de celular para suas tias que sempre ligavam para ele. Sua família o convidou a passar o Natal com eles, mas ele não sabia se ia. Já havia passado o Natal com eles no ano anterior, e era simples, mas não era por isso que não ia. Na verdade, não queria incomodá-los. Marcos sabia que iria passar o Natal com os meninos da Instituição E, que eram meninos em situação de rua e com quem ainda mantinha contato. A educadora com quem morava trabalhava naquela instituição.

Marcos fazia questão de mostrar para os meninos da Instituição E que ele estava correndo atrás para "ser alguma coisa" por meio do trabalho. Ele gostava de aparecer. Tinha vendido uma bicicleta que havia comprado um tempo atrás com o dinheiro da indenização, 
mas iria comprar outra mais bonita. Gostaria que sua história servisse para ajudar outras pessoas que pensam que a vida é difícil ou que a vida está acabando, mostrando que ele já passou por muita coisa ruim. Era importante ter fé em Deus e acreditar na vida, pois o mundo girava. Se uma hora estava numa situação ruim, na outra estaria numa situação melhor. E assim acontecia, até a pessoa chegar onde ela quisesse. Marcos poderia chegar a ter sua própria casa e seu próprio carro, ter sua vida sem dar satisfação a ninguém. Queria poder pegar o filho na escola e sair com ele a vontade, tendo dinheiro para se divertirem juntos. Também queria ver sua mulher e ter dinheiro suficiente para gastar com o necessário. Estava namorando com uma menina que morava por perto e estava gostando dela. Zilma, a mãe do seu filho Pedro, ligou para Marcos e ele prometeu dar um dinheiro para ajudar na criação do menino, mas ainda não tinha entregado o dinheiro. Tinha se arrependido de prometer dar algum valor para Zilma, porque ela estava namorando com outro rapaz. Ia esperar a audiência com o juiz quando o valor da pensão para o filho seria fixada e ele teria o direito de visitar o filho. Estava revoltado com Zilma porque ele estava muito tempo sem ver seu filho.

Já ia fazer 20 anos em breve, achava muito tempo de vida. Eram duas décadas. Gostaria de esquecer tudo o que passou de ruim, mas sempre chegava alguém para lembrá-lo de tudo o que sofreu. Quando a pesquisadora relacionou o fato dele contar sua história para ela como uma forma de fazer ele se lembrar de tudo, ele diz que era diferente, pois quando contava sua história para ela, ela reforçava o lado positivo no que viveu. $\mathrm{O}$ fato dele se lembrar do que sofreu estava relacionado a outras pessoas que agiam com ele como as pessoas do passado que o fizeram sofrer. E, com isso, ele tinha o mesmo sentimento do passado. Para se proteger, ficava observando as pessoas, mas elas o chamavam de psicopata. Então ele falava que não era psicopata, mas que era tranquilo. Já poderia ter se matado nas drogas, mas, no fundo, sabia que sua vida não era só "sofrer, sofrer e sofrer para, no final, morrer”. Percebeu que, antes não via as coisas direito e pensava que conhecia tudo do mundo. 
Muitas vezes quis se cortar e se matar mas, vendo bem, não precisava fazer isso porque o mundo era grande e existiam várias coisas diferentes.

Sobre as instituições públicas, não podia contar com elas. Se fosse depender delas, morreria de fome. Elas garantiam direitos somente oferecendo uma cesta básica e dando um "dinheirinho". Mas ninguém queria saber o que a pessoa sentia. Logo o psicólogo dizia que o tempo do atendimento havia terminado e essa pessoa tinha que ir embora. Então, esse psicólogo guardava um papelzinho com as informações que havia obtido e, no atendimento seguinte, usava esse mesmo papelzinho para continuar. Muitos psicólogos não sabiam o que as pessoas que iam para o atendimento realmente passavam.

\subsubsection{Reflexões gerais feitas por Marcos ao longo das entrevistas}

Se Marcos fosse coordenador de uma instituição, colocaria os educadores para fazerem um tipo de adaptação no início, por um tempo, para ver se algum vínculo era criado entre eles e os acolhidos, para ver se eles gostavam de trabalhar naquela instituição. Sabia que o trabalho deles era difícil pois, se com o próprio filho muitas vezes os pais tinham dificuldades na relação com ele, num abrigo era mais difícil ainda, pois os cuidadores ficavam com meninos e meninas que eles nunca viram antes e que precisam do dobro de atenção, já que sofreram muito na vida e tinham traumas.

Ao contar sua história para a pesquisadora, estava contando sua história mesmo, o que sentia, o que pensava sobre tudo e sobre sua vida. Todo mundo falou que ele não ia passar dos 18 anos, e ele já estava com quase 20. Sabia que ainda ia passar por muita coisa, "se Deus quiser”. Quando uma pessoa não era ouvida, geralmente ela se revoltava e ia roubar. A sociedade exclui as pessoas. Na opinião de Marcos, a sociedade deveria chamar a pessoa e, ao invés de dizer que ela é marginal ou bandida ou ao invés de ignorá-la, deveria perguntar porque ela estava daquele jeito e se queria mudar de vida. Mas o que ocorria é que o governo 
colocava algumas pessoas num abrigo e, para o menino que estava na rua, ir para esse tipo de instituição era a pior coisa. Lá ele conhecia outras pessoas, se identificava e aprendia outras coisas, inclusive a ser malicioso.

Dizem que instituição de acolhimento era um lugar de proteção, mas ao mesmo tempo que era proteção, não era, porque os acolhidos ficavam isolados do mundo. Mesmo saindo para ir para a escola, por exemplo, os acolhidos estavam isolados pois, se quisessem sair em outro horário, precisavam pedir autorização para um funcionário. Uma coisa é chegar para a própria mãe e pedir para sair de casa, outra coisa é pedir isso a um funcionário que vai entregar um papel para o acolhido poder passar na guarita. 


\subsection{NÍVEL TEMÁTICO 1: ESTRATÉGIAS DE RESPOSTAS EM PROCESSO DE DESINSERÇÃO SOCIAL}

Com base nas informações do nível descritivo-cronológico da história de vida de Marcos, foi realizada a análise no nível temático, a partir de questões recorrentes nessa trajetória de vida. Elementos do contexto social que se fizerem presentes, indicam como a questão da proteção e não proteção da criança e do adolescente se concretiza em algumas situações no Brasil e como foi se organizando ao longo dos últimos 20 anos. Temas recorrentes na história de Marcos denunciam a presença de longos períodos de acolhimento de muitas crianças e adolescentes, uso e tráfico de drogas por parte deles, não favorecimento do fortalecimento de vínculos familiares, valorização do uso da violência e do abuso sexual, mostrando, assim, alguns valores que permearam e ainda permeiam várias situações sociais. Observou-se, durante a história de vida aqui analisada, o surgimento e o desenvolvimento dos temas humilhação, culpa, vergonha e reconhecimento ao longo do tempo e quais foram as estratégias de respostas desenvolvidas pelo participante nos contextos os quais estava inserido.

Conforme apontou Léonetti (2007c), um fenômeno social, que pode ser concreto, como a pobreza, ou abstrato, como relações de dominação, alcança o indivíduo mediado por sentimentos que ele sente, como a humilhação ou a vergonha. E a partir desses sentimentos, ele cria e organiza uma resposta ao vivido, que são estratégias sociais utilizadas nessas situações. Além do mais, conforme Blondel (2007), as estratégias de respostas do indivíduo também podem indicar resistência, adaptação ou instalação da desinserção social, durante seu processo. Então, para que se compreendam algumas ações do sujeito, como revolta ou recusa de qualquer intervenção profissional, é importante que se compreendam também os sentimentos envolvidos. Esses sentimentos são pontos de intersecção entre uma realidade 
social e a subjetividade desse, e que atuam como pistas sobre como essa interação ocorre. Assim, a análise das estratégias individuais permite melhor compreensão do porque políticas de inserção social se chocam contra certos bloqueios, por parte dos usuários dessas políticas, que os imobilizam em relação às intervenções efetuadas e não alcançam os resultados desejados pelos profissionais (Léonetti, 2007d). No caso deste estudo, está em destaque o acolhimento institucional de crianças e adolescentes.

\subsection{Fase da Resistência}

\subsubsection{Evitando situações humilhantes}

A história de vida de Marcos começa a ser contada não pelo seu nascimento, mas a partir de um abandono que vivenciou. Durante toda sua infância e adolescência, ele apresentou a versão de que foi abandonado por sua mãe em uma lata de lixo aos 9 meses de idade, em uma cidade do interior do Estado de Goiás, onde foi encontrado e encaminhado a um abrigo institucional local. Com quase 18 anos, Marcos conheceu sua família e ouviu uma versão um pouco diferente, em que ele não foi deixado por sua mãe em uma lata de lixo, mas que foi encaminhado para uma instituição de acolhimento por profissionais que verificaram que sua mãe, ainda adolescente, não tinha condições de cuidar dele. Mas mesmo assim, permaneceu uma percepção de si mesmo de ser um lixo e não ter valor perante a sociedade. Provavelmente, essa marca importante na identidade de Marcos foi reforçada durante toda sua infância e adolescência, conforme se apresenta ao longo do texto. Assim, ter sido encontrado no lixo foi a primeira experiência de desqualificação social de Marcos, pois denotava um sentido de não ter valor perante o outro.

Outro ponto a ser considerado é a institucionalização precoce de Marcos. Segundo Blondel (2007), o processo de desinserção social inicia-se com uma primeira ruptura, que 
pode desencadear outras rupturas, chegando ao uso de recursos institucionais para a própria subsistência e, por fim, ocorrendo a entrada em um grupo marcado socialmente pela exclusão. Mas no caso em questão, esse processo ocorreu de forma abrupta, com uma ruptura (abandono da mãe) e uso de recursos institucionais imediatamente em seguida (encaminhamento para uma unidade de acolhimento), o que pode ter reforçado uma percepção de Marcos, em sua infância, não de declínio social, já que essa era uma situação vivenciada pelo nosso participante desde bebê, mas de pertencimento a um grupo, desde o início da vida, composto por crianças e adolescentes que moravam em uma instituição e eram privados de algumas situações vivenciadas por outras pessoas. Por exemplo, os acolhidos dessa instituição eram proibidos de frequentarem a escola. Quando fugiam para ir a um estabelecimento de ensino que ficava próximo da instituição, apanhavam dos funcionários da unidade de acolhimento quando retornavam.

Também, sobre o acolhimento de Marcos quando ainda bebê, pode-se fazer referência ao que Gaulejac (2006c) diz sobre o abandono precoce de uma criança, que pode propiciar o sentimento de vergonha, principalmente quando ela é transferida de uma instituição a outra. Marcos, com 9 anos de idade, foi transferido para uma segunda instituição de acolhimento, dentre outras para onde iria ser transferido posteriormente. Assim, "a vergonha está, fundamentalmente, colada ao sentimento de abandono, podendo ser este mais ou menos intenso caso seja vivido no plano fantasístico, ou caso se apoie sobre elementos da realidade" (Gaulejac, 2006c, p. 151). No caso do participante em questão, o abandono foi vivido de forma concreta, por parte da mãe, quando esse ainda era bebê, o que levou Marcos a ser institucionalizado durante toda sua infância e adolescência.

Assim, até os 9 anos de idade, enquanto ficou acolhido nessa primeira instituição, Marcos vivenciou diversas situações as quais ele qualificou de humilhantes. Em uma, era obrigado com frequência a brigar com seus amigos até machucá-los. Em outra, teve que beber 
xixi e comer fezes de cachorro. Além do mais, foi abusado sexualmente diversas vezes a partir dos 6 anos de idade, inclusive pelo diretor da instituição. Essas humilhações fizeram com que Marcos desacreditasse da vida e não confiasse em ninguém, conforme ele mesmo afirmou. E essa colocação vai ao encontro do que Léonetti (2007) coloca sobre o sentimento de impotência face a relações de forças desiguais na relação com o outro, presente na humilhação. Assim, a partir dessas experiências, ele começou a construir uma visão fatalista das situações, passando a não confiar nas pessoas e nas instituições, como se não acreditasse que essas relações pudessem ser modificadas de forma a protegê-lo.

Marcos conta que sua maior humilhação ocorreu quando foi abusado sexualmente por outro acolhido, em uma área de vegetação no interior da própria instituição, o que foi visto pelos outros acolhidos, que riram dele. Essa situação, somada ao fato de o chamarem de lixeiro, já que sua mãe o havia "jogado" no lixo, deixava-o cada vez mais revoltado, como ele afirmou. Assim, ele não viu a instituição como um local de proteção, que pudesse substituir o cuidado materno, e esse sentimento de raiva crescente indica uma maior impotência percebida nessas relações de humilhação. E somando-se a isso, cuidados básicos também não eram muito frequentes, já que Marcos, por diversas vezes, passou fome na instituição. Segundo ele, não havia uma pessoa que se responsabilizasse pelos acolhidos com frequência.

Marcos também vivenciou nesse período outros abandonos, pois havia algumas pessoas que trabalhavam na instituição por alguns meses e, após terem construído vínculos com os acolhidos, iam embora. Eram pessoas que pertenciam a um grupo religioso, que moravam em outro país e que faziam trabalhos missionários. Então, como figuras constantes de adulto de referência para Marcos, havia o diretor, que também o abusou sexualmente algumas vezes e outros dois funcionários. Ele ficava muito próximo desses dois últimos, já que eles não o violentavam. 
Nesse contexto, Marcos afirmou que a infância é quando se descobre o mundo, mas o mundo que Marcos descobriu era repleto de não proteção, de privações e de humilhações, praticamente sem adultos para o proteger. Muitos o iludiam prometendo que iriam adotá-lo, mas acabavam por não fazê-lo. Aprendeu, assim, a afastar as pessoas dele, já que não podia confiar nelas. Nesse ponto, mesmo diante de situações que reforçavam um sentimento de impotência em Marcos e uma certa passividade, tendo em vista que não percebia uma possibilidade de mudança nessas relações de forças desiguais, nota-se uma margem de ação e manobra por parte dele, em que ele buscava evitar novas humilhações, afastando as pessoas de si próprio. Em outras palavras, não criava novos vínculos pois, assim, evitava que esses vínculos gerassem outras situações de humilhação para ele. A evitação foi, então, a primeira resposta estratégica de Marcos que se pode identificar, face ao seu vivido. Léonetti (2007c) aponta que a evitação é a primeira estratégia de resposta face a um processo de desinserção. Mas no caso em questão, ele ocorre anteriormente à evitação da interiorização de uma imagem negativa de si mesmo, mas sim sobre a evitação de situações que provocam humilhação em Marcos. Ele só gostaria de ser protegido e cuidado por pessoas de confiança, o que não acontecia na grande maioria das vezes.

Essa resposta de evitação está relacionada também com o que Gaulejac (2006c) apontou em relação às primeiras experiências da criança, quando ela aprende sobre autoconfiança, autonomia e segurança, a partir da relação com o outro. Por meio da autoconfiança, da aprovação para se aproximar do outro e colocar em prática sua capacidade de individuação, tem-se, a partir desse ponto, o encorajamento para encontrar mais pessoas, que são estranhas num primeiro momento. Assim, as primeiras relações são essenciais para o desenvolvimento da autoconfiança ou da desconfiança. Um abandono materno quando ainda bebê, a não valorização de sua pessoa perante seus pares, além da possibilidade de qualquer pessoa poder humilhá-lo, pode ter provocado um sentimento de vergonha, marcante na 
constituição de Marcos enquanto sujeito. Além do mais, outra colocação de Gaulejac (2006j) é importante nesse contexto. Uma vivência humilhante, como por exemplo, ser afastado do meio familiar e passar a viver em uma instituição de acolhimento, pode gerar sofrimento na criança e no adolescente pelo fato de não estarem com suas famílias, como as pessoas em geral estão. Mas esse sofrimento não vai necessariamente implicar na internalização da vergonha. $\mathrm{O}$ acolhimento não é vergonhoso por si só. Mas algumas situações sucessivas podem ir reforçando o sentimento de vergonha que, com o passar do tempo, passa a ser internalizado. É o que vai acontecendo com Marcos, ao longo de sua trajetória de acolhimento institucional.

Assim, ao dizer que havia desistido da vida, talvez estivesse indicando, nesse ponto, que havia desistido de contestar as situações tal como se apresentavam, interiorizando uma imagem negativa de si mesmo, em torno da impotência, e vivendo a partir dela. O que poderia fazer, então, era evitar que sua vida piorasse com novas humilhações. Era como poderia agir para se proteger. E a única forma de evitar essas experiências humilhantes, que Marcos apontou como momentos de tranquilidade, era sair da instituição com seu amigo Paulo, a cavalo, e ir para um lago que havia por perto para brincarem. Em outras palavras, evitando permanecer o tempo todo na instituição de acolhimento.

Então, nessa primeira etapa de vida de Marcos, tem-se elementos que indicam que condições concretas de vida influenciaram a subjetividade de nosso participante, quer sejam o abandono em uma lata de lixo pela mãe quando ainda era bebê, o acolhimento em abrigo, a não participação de uma vida comunitária, a fome e as constantes violências sexuais e físicas aos quais foi submetido. Somadas a esses fatos, a desvalorização enquanto sujeito perante o outro, a ocupação de um lugar social que o desqualifica (o de um lixo) e o coisifica (quando é objeto de prazer para o outro nas situações de violência sexual e física), indicam o que Gaulejac (2006a) chamou de sofrimento social. É um sofrimento que agrega tanto elementos 
do contexto social, enquanto subjetivos, de forma a influenciar os modos de reação de Marcos frente a esse conjunto de fatores interrelacionados.

Aos 9 anos de idade, quando Marcos foi transferido para uma segunda unidade de acolhimento, começou a ter mais contato com a vida urbana, observando pessoas com roupas diferentes, fartura de alimentação em mercados, além de ganhar presentes. Ficou admirado e feliz com essa nova experiência, principalmente quando ganhou um suco com embalagem de um desenho animado que gostava, frente ao que disse ter sido um dos dias mais felizes da vida. Assim, nesse primeiro momento, Marcos conseguiu ressignificar a própria percepção e a percepção em relação ao outro, tendo em vista que esse novo tipo de relação não estava marcado pela humilhação, ou seja, era possível conviver sem violência.

Nesse ponto, verifica-se o que foi indicado por Carreteiro (1993) em relação à atuação do grupo na constituição identitária de cada indivíduo. Se na primeira instituição de acolhimento as relações interpessoais de Marcos foram pautadas pela humilhação, o que o levou a fazer uso da estratégia de evitamento para novas relações, em um primeiro momento de acolhida na segunda instituição, ocorreram mudanças no sentido da possibilidade de vivências respeitosas. Ao invés de humilhação, houve o reconhecimento de Marcos enquanto sujeito. Sua percepção sobre o social também mudou nesse momento, quando disse que o mundo era maior do que imaginava, mostrando a ele novas possibilidades de ser e estar no mundo.

Mas ao longo do tempo em que ficou acolhido nessa instituição, esse modo de relação foi se alterando, reforçando nele que, mesmo entre os outros acolhidos, ele era diferente, era inferior. Um amigo voltou a morar com a mãe e Marcos não tinha ao menos um familiar que o pudesse acolher. Chegou a desejar que a mãe desse amigo fosse sua mãe. Também disse que estava ficando para trás em relação aos amigos na escola. Nesse sentido, a partir de sua vivência, foi sendo marcado nele seu posicionamento na sociedade (Castel, 1994): um menino 
sem família, com poucas possibilidades de adoção e que, mesmo entre seus amigos, não conseguia acompanhar as conquistas deles, como, aprender as lições da escola. E assim, o sentimento de vergonha (Léonetti, 2007c) começa a ficar mais evidente pela distância entre uma imagem de si mesmo valorizada por ele mesmo e o olhar do outro que o desqualificava, por não alcançar o esperado pelo social, o que ia ferindo sua autoestima.

Especificamente sobre a educação formal, Marcos frequentava uma escola próxima à instituição de acolhimento. Em uma aula, ao ser solicitado para contar um pouco sobre sua história, ele falou de todas as violências que sofreu quando foi acolhido anteriormente. Falou que ainda morava num abrigo, que tinha sido encontrado em uma lata de lixo quando bebê e que não conhecia seus pais. Assim, os alunos, que eram "melhores de vida que ele", expressão que denota um sentido de superioridade dos demais estudantes em relação a Marcos, começaram a chamá-lo de lixeiro, como os acolhidos da primeira instituição. Depois desse episódio, sua relação com a escola mudou: começou a faltar aulas e a bater nos alunos. Outra questão que o incomodava era o fato de ser o maior da turma, evidenciando que estava atrasado no ano escolar em relação aos demais estudantes.

Percebe-se nesse episódio uma atualização do vivido por Marcos na primeira instituição, ou seja, o de sofrimento social, reforçando a própria percepção de ter uma identidade desvalorizada socialmente. Esse é um ponto importante e que vai talhando a identidade de Marcos pois, como indicou Léonetti (2007b), o indivíduo necessita ser valorizado e reconhecido por um grupo, o que confirma sua existência. Mas a situação da desvalorização social muitas vezes era difícil de suportar, e Marcos viveu novamente situações de humilhação, de impotência frente ao outro, fazendo uso outra vez da estratégia da evitação, que no caso, ocorria ao faltar as aulas da escola. 


\subsubsection{Agredindo o outro para se defender}

Porém, uma outra resposta também começa a se fazer presente quando Marcos, na escola, ficava agressivo e batia nos alunos, passando da evitação à agressão nas situações em que havia humilhação. Por isso, várias vezes foi expulso da sala de aula e recebeu várias advertências. Esse tipo de reação só ocorria no contexto escolar e não foi identificado na instituição de acolhimento, até esse momento. Também se evidencia um sentimento de vergonha na relação de Marcos com o contexto escolar, quando esse disse que as pessoas da escola não acharam normal sua história vivida na primeira instituição de acolhimento, e que o olhar das pessoas em relação a ele, que passaram a conhecer sua história de infância, o machucava "amargamente".

\subsubsection{Transferindo a culpa}

Outra questão que apareceu na história de Marcos é a da culpa. Começou a praticar pequenos furtos em um mercado próximo à instituição de acolhimento, junto com o amigo Paulo, mas disse que, apesar da ideia ser do amigo, as demais pessoas sempre o culpavam. Também, uma aluna da escola, com Síndrome de Down, foi abusada sexualmente dentro do estabelecimento de ensino, por outro acolhido da mesma instituição, que acusou Marcos da ação. Ninguém acreditou que não havia sido Marcos, que chorou tentando se explicar, o que o deixou revoltado. Mas ao mesmo tempo ficou aliviado pois, como tinha menos de 12 anos, não poderia ser "preso", ou seja, ser encaminhado para ficar no sistema socioeducativo em regime fechado.

A questão da vergonha já havia sido tocada em episódios na relação de Marcos com os colegas da instituição de acolhimento e com os colegas da escola. Mas, conforme apresentado no parágrafo anterior, o tema da culpa também começou a se fazer presente. Léonetti (2007c) 
indica que existe uma relação importante entre a vergonha e a culpa. Se a vergonha está na distância entre como o sujeito se vê e como o outro social o percebe, esse último desqualificando-o, a culpa aparece como uma tentativa de organização psíquica dessa contradição, quando o indivíduo se sente responsável, culpado, por não alcançar o que se espera dele. Em outras palavras, ele é responsável por não ser reconhecido no contexto social do qual faz parte.

Mas no caso de Marcos, observa-se uma dinâmica que pode ser analisada como uma estratégia de resposta para o vivido até então. A culpa está presente, mas é o outro que o culpabiliza de forma injusta, já que ele se diz inocente. Assim, ele conseguia preservar a ideia de que era excepcional e, se estava em desvantagem, era porque um outro o colocou injustamente nessa posição (Gaulejac, 2006i). Talvez assim, Marcos pudesse amenizar a culpa sentida, transferindo-a para fora de si. Esse mecanismo será observado em sua trajetória ao longo da adolescência, como uma tentativa de evitar que o sentimento de inferioridade em relação ao outro, que ele sentia, fosse acoplado à sua identidade.

Uma outra forma de Marcos justificar seus atos, transferindo a culpa, que muitas vezes recaía sobre ele, ao outro, era focando seu prontuário. Nesse documento, os profissionais escreviam sobre o acolhido, sua trajetória, suas demandas, as intervenções realizadas e os resultados alcançados. Segundo ele, havia informações nesse documento que o desqualificavam, afirmando que ele era "revoltado" e que não havia perspectiva de melhora quanto a um futuro saudável e integrado na sociedade. Mesmo quando os profissionais o chamavam para conversar, não havia uma escuta que pudesse considerar o que ele dizia, já que davam mais valor ao que estava no prontuário do que em sua versão sobre as situações. Nesse ponto, mais uma vez a culpabilização recai sobre o outro que não o compreende, que interagia com ele conforme alguns rótulos já estipulados. Então, por mais que houvesse um espaço de escuta, Marcos não se sentia ouvido, pois para ele, sempre iriam tentar inferiorizá- 
lo. Com isso, ele mantinha uma autoimagem positiva, transferindo para o outro a responsabilidade de não apreender suas reais e positivas intenções.

\subsubsection{Buscando reconhecimento por meio de relações familiares}

Por mais que Marcos buscasse transferir a culpa ao outro pelas situações desfavoráveis nas quais muitas vezes encontrava-se, na tentativa de preservar uma autoimagem positiva, havia situações da realidade concreta que passavam a ele a mensagem de que ele era inferior aos outros, sem possibilidades de mudar essa situação. Na Instituição B, onde ficou acolhido entre 9 e 15 anos de idade, havia uma funcionária de quem Marcos gostava muito e a chamava de mãe, mas ela algumas vezes pedia para que ele não a chamasse dessa forma. Ele não possuía qualquer familiar com quem pudesse sair nos finais de semana, como outros acolhidos, chegando à conclusão, assim, que estava sozinho. Por mais que relacionasse essa instituição a uma família, destacou que davam pouca atenção a ele. Assim, parece que ele tinha o desejo de estabelecer uma relação interpessoal que não fosse com profissionais, mas que suprisse a falta de uma relação afetiva. Tentou uma maior aproximação com alguns da equipe algumas vezes, mas não obteve sucesso, já que sempre algo indicava que era uma atuação profissional e não familiar. Então, quando se pensa no funcionamento institucional, por mais que o profissional se empenhe e trabalhe da forma mais cuidadosa possível, nunca vai ser o suficiente para suprir essa carência.

Com isso, pode-se indicar essa situação como um dos limites do acolhimento institucional. Por mais que se busque uma aproximação com a vivência da família dos acolhidos, inclusive utilizando termos como casa lar e mãe social, essa função nunca será desempenhada nesse contexto, tendo em vista sua organização e seus objetivos. Na instituição, as relações possuem um tempo para serem estabelecidas e finalizadas, de acordo com o horário de trabalho de cada um, com objetivos de reintegração familiar e/ou comunitária, onde os profissionais não estão presentes ou disponíveis 24 horas por dia. Por 
mais que em uma família, os pais também não estão presentes em tempo integral, pois saem para trabalhar, por exemplo, os filhos sabem que podem contar com eles se precisarem. Existe uma estabilidade nas relações e o pertencimento a esse grupo, o que não acontece em uma instituição de acolhimento de forma satisfatória. A questão do pertencimento também fica prejudicada nesse local pois, o grupo, está sempre se modificando, com entrada e saída de novos acolhidos e, muitas vezes, de profissionais também. Assim, o que Léonetti (2007b) indica como características importantes da identidade, que são necessidade de valorização e necessidade de identificação a um grupo, sendo aceito e reconhecido por ele, não ocorre de forma satisfatória com Marcos. A única forma que Marcos encontrou de estabelecer relações familiares era constituindo sua própria família. Ele gostaria de ter um filho cedo para poderem brincar e passear, como se quisesse fazer com o filho o que não fizeram com ele. Mas a relação com a primeira namorada não foi o suficiente para ele, pois ela era estéril e não poderia engravidar.

\subsubsection{Autopunição}

A transferência da culpa ao outro, pela vergonha sentida por não alcançar o esperado e não ser reconhecido socialmente, não era suficiente para Marcos aliviar a angústia que sentia por se perceber inferior aos demais. Então, complementando essa estratégia de transferência da culpa, ele também se punia por meio de cortes nos pulsos. Nessas horas, pensava que tudo o que acontecia de ruim com ele era culpa sua e se perguntava porque tinha nascido, se era para sofrer. O primeiro episódio ocorreu quando apanhou de um adolescente que quase quebrou sua costela e Marcos, que ficou muito angustiado, ao invés de "furar" esse adolescente com uma faca, cortou o próprio pulso. Sentiu um alívio e uma sensação boa de imediato, e por isso, desse dia em diante, se cortava sempre que se sentia angustiado. 
Percebeu que era melhor descontar o que sentia em si mesmo do que nos outros, pois tudo ficava normal depois.

Segundo Drieu, Proia-Lelowey e Zanello (2011), o adolescente tem a tendência de projetar suas tensões no corpo, para poder melhor dominá-las. Para Cedaro e Nascimento (2013), em pesquisa realizada a partir de relatos de mulheres jovens, entre 15 e 21 anos, que estavam em atendimento em um Centro de Atenção Psicossocial (CAPS), a dor sentida com os cortes ajudava essas pacientes e suportarem a angústia de viver, esboçando, ao mesmo tempo, um pedido de socorro e uma maneira de se sentirem e se manterem vivas. Assim, com a dor do corte autoinfligido (Dinamarco, 2011), é possível que a atenção do sujeito seja desviada para a parte do corpo que está dolorida, numa busca de substituição da dor psíquica pela dor física. E ainda, tem-se o "... ferir-se como delimitador entre o eu e o outro como se o sujeito, através da ferida feita em si mesmo, voltasse a sentir que o corpo é seu, afastando as demandas invasivas do outro" (Dinamarco, 2011, p. 32).

No caso de Marcos, a automutilação tinha algumas funções: de alívio frente às tensões psíquicas às quais era confrontado; de tentativa de controle da angústia sentida; de expiação da própria culpa (Dinamarco, 2011) por ser inferior e inadequado frente aos demais e de uma busca por sentir-se vivo e retomar o controle sobre o próprio corpo. Além da sensação corporal prazerosa, não era necessário que brigassem com ele por ter machucado um colega, afinal, ele mesmo se punia por estar naquele tipo de situação. Mas ao mesmo tempo em que falava isso, se culpabilizando por sua inferioridade social, transferia a responsabilidade para outrem, justificando que era o mundo que não prestava, não ele.

Essa ambivalência, se culpar versus culpar o outro, vai oscilando ao longo de toda sua trajetória de vida, sempre na tentativa de buscar uma explicação pelo que vivenciava e, ao mesmo tempo, preservar uma boa autoestima, protegendo a própria identidade. $\mathrm{O}$ paradoxo existente era, de um lado, se ninguém o queria, se era inferior, era porque Marcos não havia 
feito o suficiente para ser melhor, para ser aceito e respeitado, ou seja, era por culpa sua. Ao mesmo tempo, ele não era tão ruim assim, na verdade, eram os outros que não o compreendiam, não o ouviam o suficiente pois já o tinham rotulado de forma negativa. Além de se cortar, Marcos aliviava a angústia que sentia quando fazia uso de drogas ilícitas.

\subsubsection{Quebrando regras para ser reconhecido}

No trato com as outras pessoas, Marcos relatou que somente olhavam para ele quando ele descumpria alguma norma ou regra da instituição. Assim, numa relação paradoxal, fazia algo considerado errado para que o reconhecessem enquanto sujeito, mas esse tipo de ação reforçava para o outro, elementos negativos de sua pessoa, como num ciclo onde o reconhecimento esperado por Marcos, que abarcasse aspectos considerados positivos, nunca iria ser alcançado. Com isso, alguns rótulos foram sendo reforçados em relação a ele e marcados concretamente em sua história, por meio do registro em seu prontuário institucional.

Marcos só gostaria de ser ouvido, de desabafar o "que tinha no peito", mas não conseguia, pois os profissionais da instituição, segundo ele, o viam como uma pessoa ruim,

perversa e "do mal". Quando ele disse que na verdade não gostaria de fazer o que fazia, observa-se novamente uma tentativa de transferência da culpa ao outro pois, a responsabilidade pelo que acontecia não era dele, mas sim do outro que nunca o compreendia. Por mais que alguém parasse para conversar com ele, ele afirmava que essa pessoa não era de confiança, pois passava as informações para outros profissionais, que as usavam contra ele e o deixavam revoltado. Esse ponto é importante ser ressaltado pois, em uma instituição de acolhimento, é prezado o trabalho em equipe e em rede para que se tenha maior eficácia nas intervenções. Mas para o adolescente, que muitas vezes busca (re)constituir relações de confiança, nem sempre esse modo de relação é satisfatório. Tem-se, assim, expectativas que não são alcançadas, tanto para os acolhidos, quanto para os profissionais, pois ao mesmo 
tempo em que é importante confiança mútua para que o adolescente consiga se expressar e construir um projeto de vida junto a um profissional, este precisa identificar qualidades e potencialidades no adolescente para vislumbrar a concretização desse projeto. Ao mesmo tempo, para que esse profissional consiga, com o acolhido, auxiliar na concretização desse projeto, ele precisa compartilhar algumas informações com outros profissionais, num trabalho em equipe e em rede, o que pode ser visto pelo adolescente como traição.

Além do mais, Marcos também indicou em sua história de vida que alguns profissionais da instituição de acolhimento, ao ouvirem o que ele tinha a dizer sobre o que havia vivenciado, olhavam para ele com dó, comentando que era uma pena pois sua história era muito triste. E isso Marcos não gostava de ouvir. Nesse contexto, destaca-se que a vergonha sentida por aquele que conta sua história provoca ecos naquele que ouve, penosos em termos psíquicos, que geram sentimentos contraditórios (Gaulejac, 2006e) e causam certo embaraço. $\mathrm{Na}$ interação, o movimento ocorre em duplo sentido, em que reconhecer a vergonha do outro está relacionada com o reconhecimento da própria vergonha, das próprias falhas. Como respostas, a vergonha pode provocar no outro reações contraditórias entre a identificação com aquele que apresenta uma história composta por muitas situações vergonhosas e sua rejeição, entre o desprezo e a piedade, entre a solidariedade e a distância. No caso do participante desta pesquisa, sua história provocou o sentimento de piedade em alguns, e essa piedade é sentida como insuportável por aquele que conta a própria história, sendo a pior de todas as violências. Além do mais, pode se sentir incompreendido por esse outro (Gaulejac, 2006d). Foi o que aconteceu com Marcos, ao expor suas vivências a alguns dos profissionais da segunda instituição de acolhimento onde ficou entre os 9 e os 15 anos de idade. Os que ouviam sua história de vida, exprimiam pena e dó em relação a ele, reforçando nele uma imagem negativa de si mesmo, vinda do social. 
Então, ao longo do que ia vivenciando, Marcos ia criando e experimentando estratégias de respostas, às vezes combinando mais de uma estratégia ao mesmo tempo. Pontua-se que a estratégia da transferência da culpa mesclou-se com a quebra de regras em busca do reconhecimento, pois mesmo que fizesse algo em desacordo com o estabelecido, não era por sua culpa. Na verdade, segundo ele, não queria fazer o que fazia, mas sim, chamar a atenção do outro e essa era a única forma que encontrou para atingir esse objetivo. Mas essas estratégias não eram eficazes para o que ele buscava, pois sua imagem de ser e estar inadequado perante o grupo era reforçada de uma forma ou de outra: ou pela punição por agir de forma inadequada ao quebrar uma regra, sendo responsabilizado pelos seus atos, ou ao perceber o embaraço ou a pena sentidos por aquele que via em sua história de vida, a grande quantidade de situações vergonhosas que ele havia vivenciado. Essas situações reforçaram em Marcos a descrença nas pessoas, em alguém que realmente se importasse com sua história, ou seja, descrença de que alguém pudesse identificar pontos positivos em sua trajetória.

\subsubsection{Fase da Adaptação}

\subsubsection{Fazendo aliança junto com pares em busca de reconhecimento: uso de estratégias} coletivas

Depois que Marcos foi transferido da segunda (B) para a terceira (C) instituição de acolhimento, ele começou a fazer uso de estratégias mais coletivas frente ao que vivenciava, em busca de proteção e reconhecimento. Segundo Blondel (2007), após uma fase de resistência à vergonha, sentida a partir do olhar do social que desqualifica o sujeito, e da tentativa fracassada de controlar os efeitos de insegurança que essa situação coloca, esse sujeito se adapta psicologicamente às situações que vive, no intuito de diminuir seu sofrimento. Assim, passa a reagir conforme o grupo ao qual passa a fazer parte. No caso de 
Marcos, com uma nova transferência de instituição de acolhimento, ele começa a usar esse espaço a seu favor.

Num primeiro momento, aproximou-se de um acolhido mais velho e conseguiu ter a confiança dele. Assim, esse não deixaria que uma pessoa o prejudicasse ou o ferisse, pois era respeitado na instituição. Mas com o tempo, esse e outros adolescentes mais velhos foram tornando-se adultos e saindo do abrigo, quando Marcos viu que precisava se impor perante os demais meninos e meninas da instituição. Na sua visão, os acolhidos não eram bem cuidados pelos profissionais e assim, ao contar sua história para eles, houve alguma identificação dos acolhidos com sua trajetória de vida, que passaram a respeitá-lo. A partir da compreensão do grupo do vivido por Marcos, do compartilhamento dos sofrimentos, das humilhações e de situações vergonhosas, foi possível para ele fazer uma aliança com esse grupo, que reconheceu seu sofrimento, suas angústias, e viu que ele tinha tido a força necessária para passar pelo que passou. Conforme aponta Gaulejac (2006f), todas as vítimas de estupro e violência física necessitam que o testemunho que tenham a dar sobre o que viveram seja reconhecido pelo social, em um coletivo que não as rejeite, nem as humilhe novamente.

E também, essa estratégia coletiva está relacionada com a quarta etapa do processo de desinserção social. No caso de Marcos, as três primeiras etapas não podem ser aplicadas tal qual Blondel (2007) indicou, conforme apontou-se no início deste capítulo, pois Marcos vai direto da ruptura com o meio familiar para o uso de recursos institucionais, não vivenciando o encadeamento de rupturas que ocorre entre a primeira e a terceira etapa. E na terceira instituição, ele se permitiu entrar em um grupo marcado socialmente pela exclusão. Nesse momento, começou a fazer uso do grupo a seu favor, distanciando-se de estratégias e respostas individualizadas. Então, por mais que o processo de desinserção social seja repentino e já coloque o sujeito em um grupo social desfavorável, a entrada de fato em um grupo social excluído pode demandar certo tempo para a internalização dessa nova condição 
pela pessoa. E esse tempo está relacionado com o que Léonetti (2007c) aponta, quanto às respostas dos sujeitos em um processo de desinserção: evitação, busca da revalorização da própria identidade para, por fim, ocorrer a interiorização de uma autoimagem negativa. Essa última estratégia de resposta, evidenciada em Marcos nesse durante a fase de adaptação, indica que ele, assim como caracterizou a autora, passaria a se submeter às regras do jogo, ou seja, iria agir de acordo com a forma com que o contexto era organizado, no caso, a instituição de acolhimento. E o reconhecimento pelo grupo de pares ao qual Marcos alcançou, também incluiu conquistar um lugar de liderança nesse grupo, não era qualquer lugar. Assim, ele conseguiu algum respeito entre os acolhidos, os quais valorizaram algumas características de sua identidade, aumentando sua autoestima. Foi a forma como conseguiu se distanciar de uma autoimagem desvalorizada. Com isso, conseguiu algumas vantagens, como pedir para um acolhido ir buscar maconha na rua, já que ele tinha brigado com alguém fora da instituição e não queria se colocar em risco. Mas vale ressaltar que o reconhecimento de Marcos ocorreu entre os acolhidos, mas não entre os profissionais da instituição. Quando Marcos não concordava com alguma questão do local, a única forma de expressar e ser visto pelos profissionais, era organizando rebeliões, nas quais conseguia convencer os demais acolhidos a quebrarem objetos, danificarem as casas ou incendiarem algo. Assim, por meio desses atos violentos, conseguia amenizar a dor que sentia "no peito" e a sensação de revolta que estava sempre presente.

Dentre as situações que Marcos não concordava e, como resposta, organizava os demais acolhidos para se rebelarem de diversas maneiras, estava a troca das profissionais chamadas mães sociais, que ficavam nas casas junto aos acolhidos durante toda a semana, por cuidadores sociais, concursados e que trabalhavam em regime de escala. Dessa forma, as novas equipes eram organizadas em duas para o dia e duas para o noite, que trabalhavam se revezando. Não havia continuidade nas intervenções, por mais que eles registrassem o que 
ocorria em cada plantão, em um livro de ocorrências. Para Marcos, essa nova equipe não estava lá de coração, como as mães sociais, que realmente se preocupavam com os acolhidos. Os cuidadores sociais focavam seu trabalho na rotina, nos horários e em manter a ordem da casa. Muitas vezes ficavam em uma sala própria para eles, conversando entre si, sem interagirem com os meninos e meninas.

Mas como Marcos ocupava um lugar de liderança frente aos acolhidos, muitos cuidadores se aproximavam dele, tentando fazer amizade, pois sabiam que assim Marcos e os outros não iriam provocar confusão no seu plantão e ficariam seguros. Então, diante dessa estratégia de alguns da equipe, Marcos criava algumas regras, segundo as quais eles o deixavam fumar maconha dentro da instituição, por exemplo, numa espécie de troca de favores.

Outro ponto em que Marcos não estava de acordo, era em relação à postura dos profissionais em acionarem a polícia em caso de brigas, rebeliões ou uso de drogas no interior da instituição. Muitas vezes ele foi conduzido à Delegacia da Criança e do Adolescente dentro de viatura policial, ou até no próprio carro da unidade de acolhimento e, chegando lá, não tinha mais nada a fazer, a não ser entrar de cabeça baixa e com as mãos para trás. Pelo fato de usar chinelo e bermuda, era chamado de "vagabundo" pelos policiais. Certa vez, um policial disse que não sabia porque a Princesa Isabel havia acabado com a escravidão no Brasil, pois era para ele estar com uma enxada trabalhando e não dando trabalho. Então, os episódios da delegacia reforçaram em Marcos que seu comportamento era inadequado e que sua cor de pele não era bem aceita socialmente, indicando para ele o único lugar ao qual se sentia reconhecido positivamente e respeitado: entre os demais acolhidos. 


\subsubsection{Autopunição por novo abandono}

O pertencimento ao grupo de acolhidos não era suficiente para Marcos suprir a falta de vínculo familiar. Nessa instituição, começou a namorar com uma também adolescente, chamada Zilma, com quem planejava formar uma família. Mas para ele, ela não correspondia ao seu amor e, como resposta, foi violento com ela várias vezes, machucando-a. Essa insegurança refletia o medo de outro abandono, como se tivesse que forçar Zilma a ficar com ele a qualquer custo, seja pelo amor, seja pelo medo. Mas ela não suportou esse controle sobre ela e as violências que vivenciava e, em uma noite, disse que estava terminando o namoro. Marcos, logo em seguida, cortou um de seus pulsos com um pedaço de vidro, precisando ser hospitalizado por uma noite pelo risco de suicídio. Para ele, a dor da perda e do abandono era insuportável e sabia que cortando o pulso, essa dor seria aliviada. Foi o que fez. Nesse episódio, identifica-se que a culpa por não ser o suficiente para Zilma, não alcançar as expectativas dela em relação a um companheiro, a ponto dela desprezá-lo, realçou a vergonha sentida e a culpa por não ser capaz de evitar outro abandono. E com isso, merecia ser punido, cortando-se. Ao mesmo tempo, buscava influenciar Zilma, tentando fazer com que ela se sentisse culpada por ele ter se cortado por causa da escolha dela em terminar o namoro, numa tentativa de forçar uma reaproximação entre os dois.

\subsubsection{Perda da liderança, perda de lugar no grupo : saída do grupo}

Após a tentativa de suicídio com o término do namoro com Zilma, Marcos ficou em uma clínica, internado, por 40 dias, para desintoxicação do uso de drogas e atenção sobre a ideação suicida. Estava com 17 anos. Mas depois do seu retorno à instituição de acolhimento, verificou que perdeu a liderança sobre aos demais, pois não era forte o suficiente para estar à frente desse grupo. Em uma grande briga, envolvendo a maioria dos adolescentes na 
instituição, os dois meninos que estavam na liderança se aproveitaram da confusão para ferir Marcos no tórax, com um caco de vidro. Ele foi socorrido, levado ao hospital, mas seu lugar nesse grupo já estava comprometido. A intenção dos novos líderes era literalmente anular sua existência nele.

Os dois adolescentes que o feriram foram cumprir medida socioeducativa de internação, mas a liderança não foi reconquistada por Marcos. Buscando oferecer alternativas a ele, a equipe que o acompanhava o chamou para conversar, dizendo que seria bom para ele ficar um tempo em um hospital psiquiátrico, já que dizia constantemente que iria se matar. Ele reagiu de forma violenta à proposição, quando alguns profissionais o colocaram no carro da Unidade e o levaram para o hospital. Como o médico que o avaliou não identificou nada de errado com Marcos, a equipe da instituição de acolhimento o conduziu novamente à Delegacia da Criança e do Adolescente, com a acusação de ameaça. Com isso, teve que cumprir 45 dias em regime fechado. Para ele, quando alguém está preso, é visto pela sociedade como um "vagabundo", mas na verdade, ele era somente uma pessoa que não sabia se entender nem entender as outras pessoas. Ele só queria viver, sem prejudicar ninguém, nem a ele mesmo. Mas não sabia como fazer. Nesse ponto, fica clara a vergonha que marcava sua identidade, com uma distância entre como os outros o viam, que era como um "vagabundo", e como Marcos se percebia, como alguém que não sabia como fazer para viver nesse mundo de forma saudável e integrada. Suas mudanças de estratégias, observadas até esse momento, indicam essa busca constante de integração e reconhecimento pelo outro.

Depois de cumprir a medida de internação, foi para a Semiliberdade, medida em que o adolescente pode ir para casa aos finais de semana, mas fugiu assim que chegou no local. Foi parar na rua, sendo a primeira vez em que ficou alguns dias seguidos morando na rua. Não queria voltar à instituição que estava antes, pois sabia que não o queriam lá. Dessa forma, ele queria evitar outra situação de rejeição, tanto pelos profissionais, quanto pelos acolhidos, que 
antes o respeitavam por sua liderança sobre eles. Mas havia deixado sua namorada, Zilma, grávida, qualificando a gestação como algo positivo, pois de alguma forma, havia a possibilidade do estabelecimento de vínculos familiares.

\subsubsection{Busca de reconhecimento social $X$ busca de reconhecimento entre os pares}

Como Marcos estava na rua, ele foi encaminhado para outra instituição de acolhimento, a qual recebia adolescentes e jovens em situação de rua. Nesse momento, ele passou a integrar outro grupo, um pouco diferente dos que havia composto antes. Não era uma instituição que acolhia crianças e adolescentes encaminhadas pelo Judiciário, mas sim um local que recebia aqueles que já tinham vivência de rua e que tinham contato com a dinâmica de sobrevivência nesse espaço, o que incluía uso e trafico de drogas, furtos e roubos, além de exploração sexual. Marcos aceitou ir para essa instituição pois não havia outra para ir. Ou era ficar na rua, ou ir para lá, já que ele não queria voltar para a última instituição onde estava acolhido. Ele já estava com 17 anos, inviabilizando que outras instituições de acolhimento o acolhesse, ainda mais com o histórico de desrespeito às regras e episódios violentos aos quais participava. Assim, passou a participar de uma rotina mais próxima da vivência de rua.

Assim que chegou à Instituição D, fazia questão de se colocar de forma diferente dos demais acolhidos, afirmando que não era como eles. Também relatava que passava um pouco de sua história aos demais, na tentativa de se aproximar deles, repetindo a estratégia que utilizou na instituição anterior, com a diferença de que nesse novo local, ele não obteve os mesmos resultados. Para pertencer a esse novo grupo, era preciso participar das atividades e situações que realizavam, diretamente relacionadas com a vivência na rua. Nessa instituição, havia certo movimento entre a vida no abrigo e a vida na rua, pois os profissionais consideravam que a saída da rua iria acontecer aos poucos, paulatinamente. 
Mas Marcos estava em uma circunstância nova e havia em sua trajetória, uma vivência marcada pela humilhação; pelo sentimento de impotência em mudar uma situação em que era subjugado; pelo sentimento de vergonha quando o outro reforçava que ele não havia se esforçado o suficiente para ser melhor e, assim, não alcançando o que esperavam dele, apesar dele perceber que não era tão ruim assim; pelo sentimento de culpa que muitas vezes o invadia, por não conseguir ser melhor; e pelas constantes tentativas de reconhecimento pelo social. Nesse momento, ele agiu de forma paradoxal: de um lado, buscando reconhecimento no grupo dos acolhidos, se inserindo na rotina deles; de outro, buscando reconhecimento social, aqui representado pelos profissionais do acolhimento e da escola onde passou a frequentar, tomando algumas atitudes positivas coletivamente.

Buscando reconhecimento social, tirou a segunda via de seu documento de identificação, se alistou no serviço militar, o que o fez sentir incluído na sociedade, e foi aprovado para receber uma bolsa de estudos por um ano, onde poderia continuar os estudos regulares pela manhã e fazer cursos profissionalizantes a tarde. Mas, ao mesmo tempo, Marcos sentia a necessidade de pertencer ao grupo dos acolhidos, passando, ao mesmo tempo, a usar mais drogas e a fazer parte de exploração sexual com homens. Depois saiu da exploração e começou a vender drogas, pois não gostava de ficar sem dinheiro, mas disse que o mais importante não era o dinheiro, era a "adrenalina" e ser respeitado pelos pares. O uso da palavra adrenalina remete à busca de uma potência energética (Gaulejac, 2006g), de sentir-se vivo. No meio desse dilema, desse conflito, disse que precisava colocar a "cabeça no lugar", sabia que ainda estava em tempo para organizar sua vida, indicando que o desejo de reconhecimento social ainda estava presente.

Sobre o uso de drogas, dizia que era para diminuir a depressão, a dor no peito que sentia, afirmando que a sensação do crack era melhor do que ter relação sexual. Mas depois do efeito, disse que a depressão aumentava. Usou crack algumas vezes mas, quando viu que 
os usuários desse tipo de droga ficavam destruídos, muito magros e cada vez mais egoístas, já que faziam de tudo para conseguir a droga, parou de usá-la, ficando com outros tipos de drogas.

A situação paradoxal em que Marcos se encontrava estava relacionada com a admissão da própria vergonha, onde, ao reconhecer sua situação desfavorável socialmente, suas falhas e dificuldades, poderia buscar reparar esses déficits por meio do estudo e da aceitação das intervenções dos profissionais, tanto da escola quanto da instituição de acolhimento, para poder atingir um nível esperado e aceito pelo coletivo, inserindo-se socialmente. Mas em sua trajetória, ele havia buscado o tempo todo não admitir essa vergonha, não se ver inferior aos demais, pelo sofrimento que estava atrelado a ela e tocava profundamente sua autoestima. Então, do outro lado desse paradoxo, estava a não aceitação da própria vergonha, a não aceitação de que era inferior, recusando as normas sociais como que recusando a legitimidade do olhar social que lhe era lançado (Gaulejac, 2006h).

Mas essa situação não iria se sustentar por muito tempo, pois com o passar das semanas, tanto os profissionais quanto os acolhidos passaram a desacreditar em Marcos e ele estava em uma situação de ambivalência identitária. A situação paradoxal em que se encontrava não lhe rendeu reconhecimento nem socialmente, representado pelos profissionais, nem em seu grupo de pares, já que ele não conseguia começar e terminar uma tarefa de forma satisfatória, conforme as expectativas de ambos os grupos. Ele não conseguiu continuar a estudar e não se apresentou no dia marcado pelo alistamento militar, além de ter dificuldade em seguir algumas regras da instituição de acolhimento, não alcançando o esperado pelos profissionais. Ao mesmo tempo, passou a não frequentar mais a rua e, com isso, deixou de traficar drogas, não agradando aos demais acolhidos. Esses dois grupos ficavam falando o que ele deveria fazer e, se fosse antes, como ele ressaltou, Marcos revidaria com violência, o que não aconteceu. Era muita humilhação, mas não reagia. Os acolhidos diziam que ele estava 
com medo de voltar para a rua, querendo deixá-lo inseguro. Mas Marcos estava cansado de ficar em instituições de acolhimento, sentia-se abandonado, sem ninguém. Não alcançava reconhecimento social, o que verificava quando andava na rua e, por usar bermuda, chinelo e boné, as pessoas o olhavam com desprezo. Na escola, não conseguia se concentrar nas aulas e era tido como "doido". Na instituição de acolhimento, Marcos era visto como "marginal", "drogado" e "abandonado". Entre os demais acolhidos era visto como covarde, por mais que não concordasse com eles. Assim, com as falhas sucessivas de suas estratégias de preservar sua autoestima, eram muitas as situações que o colocavam de forma desfavorável frente aos demais.

Marcos, ainda fazendo uso da estratégia da transferência da culpa, não concordava com o olhar do outro que recaía sobre ele, buscando manter uma autoimagem positiva, não percebendo até que ponto essa postura provocava o desprezo sentido pelo coletivo em relação a ele, quando ficava numa postura de desdém ou de agressividade. Ao não se perceber enquanto aquele que não possuía os elementos necessários para uma vida coletiva e integrada socialmente, numa tentativa de fugir da própria vergonha, ele a provocava, na medida em que favorecia que o outro o desprezasse ainda mais (Gaulejac, 2006i). Mas, como ele mesmo dizia, era ruim gostar mais dos outros do que os outros dele. Queria olhar e querer o bem das pessoas, mas também gostaria de ver isso nas pessoas em relação a ele. Mas as pessoas sempre queriam seu "mal", indicando que a descrença nas pessoas, que desenvolveu ainda na infância, perdurava. Então, ele era egoísta e se defendia antes delas se aproximarem. Essas pessoas somente olhavam para a aparência e não para o que ele sentia. Ao mesmo tempo, ele não as deixava acessar seus sentimentos. Para ele, os outros não sabiam o que o levou a ser daquele jeito, numa postura de vítima e de cobaia do mundo, como também havia dito. Em outras palavras, se fechava para se proteger de relacionamentos humilhantes, como se todos fossem assim, e esse fechamento provocava mais humilhação. 
Um momento importante do paradoxo em que se encontrava ocorreu quando Marcos estava presente no momento em que dois colegas da unidade de acolhimento, mataram um homem que passava pelo local, um espaço público, quando os três faziam uso de drogas. Era o extremo da adrenalina, mas também do medo. Era o extremo da recusa das normas sociais, do outro que legitimava sua inferioridade, mas, ao mesmo tempo, existia o medo de ter que assumir esse lugar de não adequação à sociedade, definitivamente. Marcos disse que somente ajudou a agredir aquele homem, no início da briga, mas que não o havia matado. E a fim de mostrar que não tinha responsabilidade sobre o ocorrido, quando foi chamado para prestar esclarecimentos em uma delegacia de polícia, confirmou que somente os dois colegas é que eram os responsáveis pela morte. E isso, entre os acolhidos, era considerada uma traição imensa, já que a regra posta é nunca denunciar um colega, por mais que ele tenha culpa. Assim, buscando preservar sua autoimagem, Marcos quebrou essa regra de convivência e passou a ser ameaçado de morte pelos dois e mal visto pelos demais acolhidos. Ele ficou dias sem dormir, com a cena da morte cruel que presenciou, "na mente". Seu pertencimento a esse grupo estava comprometido.

Nesse meio tempo, sua família, que não tinha boas condições financeiras, a qual Marcos nunca tinha visto, havia sido localizada. E aproveitando um almoço de domingo, em que avós, tios e primos maternos se reuniram para receber e conhecer Marcos, ele resolveu ficar por lá mesmo. Tinha se sentido acolhido, mas ao mesmo tempo, estava com medo de voltar à instituição de acolhimento pelas ameaças que havia recebido, relacionadas ao homicídio.

\subsubsection{Busca de reconhecimento e pertencimento familiar}

Marcos foi morar com um tio e esperava receber muito cuidado de seus familiares, ser especial para eles, ser amado de verdade, como nunca o fora antes, chegando a dizer que após 
a primeira noite com eles, era como se tivesse nascido de novo. Mas ao mesmo tempo, ele começou a desconfiar que seus familiares estavam, na verdade, interessados no dinheiro a que ele tinha direito de receber, no valor de $\mathrm{R} \$ 13.500,00$. Muitos tios falavam para ele que estavam a sua procura, pois assim que completasse 18 anos, ele não teria mais o direito de receber esse valor. Nenhuma outra pessoa poderia receber esse dinheiro e ele já estava com 17 anos. Diziam também que o avô não tratava bem as pessoas, mas que o recebia para passar alguns momentos em sua casa porque, com certeza, também queria uma parte do dinheiro. Como sua mãe havia morrido em um acidente de caminhão, ele, como único herdeiro, poderia receber uma espécie de indenização do Estado, advinda do Seguro Obrigatório, imposto que os condutores devem pagar anualmente.

Assim, sua expectativa de recuperar um tempo perdido quando ainda era bebê, após seu "novo nascimento", quando se espera uma amor incondicional dos pais e cuidados constantes, foi transformado em um amor condicionado ao dinheiro. Ao invés de ser reconhecido pelo seu jeito de ser, sua aceitação na família estava atrelada ao que ele iria receber financeiramente. Essa era a percepção de Marcos e que orientou suas atitudes no período em que esteve na casa do tio. Toda a atenção que recebia, não era suficiente. O tio e sua esposa colocavam para ele as regras da casa e dividiam as tarefas, mas Marcos não seguia o que era combinado. E nas discussões, dizia que via que eles não gostavam dele, só queriam humilhá-lo. Essa situação parece ter ocorrido, pois houve uma distância entre como Marcos esperava ser recebido e tratado pela família e como tal relação ocorreu na prática. Como toda convivência, existem regras e o papel de cada um é definido em relação à contribuição de todo o grupo. Mas Marcos gostaria que a vida de seus familiares fosse organizada ao seu redor, como se devessem isso a ele, pelo tempo que foi afastado deles. Mas esse mundo ideal não se concretizou e o mundo real, onde existem limites e normas a serem seguidas, se impôs. Essa situação pode ter sido reforçada pelo fato de que, enquanto estava acolhido 
institucionalmente, recebia as refeições já preparadas e não participava ativamente da manutenção e limpeza da casa, já que havia profissionais encarregados desse serviço. Por mais que vivesse em grupo, as tarefas não era partilhadas entre todos os acolhidos, dificultando o aprendizado a esse respeito. E na sua família, buscou repetir essa mesma postura. Assim como os profissionais que trabalhavam pelos meninos e meninas, ele desejava que sua família também atuasse dessa forma, sendo criticado por isso. Porém, o abandono inicial vivenciado por Marcos o colocou em uma busca afetiva que nunca era alcançada, essa falta nunca era suprida, nem pelos profissionais da instituição de acolhimento, nem por seus familiares. Marcos fez uso de estratégias que aprendeu nas instituições, como uso do grupo a seu favor e quebra de regras para ser reconhecido, fracassando nessa integração. As críticas que recebeu dos familiares foram vistas por ele como humilhantes, provavelmente porque enviavam a ele a mensagem de que era inadequado, não atingindo, assim, as expectativas deles em relação a Marcos, conforme havia vivenciado até então nas instituições. Mas ele, novamente, não percebia como seu comportamento influenciava essa percepção familiar.

Marcos voltou a namorar com Zilma, que tinha tido um filho dele, e ela e o filho o visitavam nos finais de semana. Mas com as constantes brigas entre os dois, o não cuidado de Marcos com seu filho e a interferência de um tio nessa situação, levou a avó, dona do terreno, a não querer que Marcos continuasse morando naquele local. Ela tinha medo de que algo pior acontecesse, entre ele e o tio, como a morte de um deles por briga.

Com o dinheiro da indenização, Marcos saiu da casa do tio e alugou um quarto perto, pois não queria perder o contato com sua família. Mas a atenção que recebeu não foi o suficiente novamente e somente sentia que era desprezado pela própria família. Depois de pouco tempo, mudou-se para perto de Zilma, que ainda morava com o filho em uma instituição de acolhimento, mas dependia das visitas dela para que ela arrumasse a casa e fizesse comida. Ele não organizava o espaço onde estava. Após uma briga com ela, Marcos a 
agrediu e foi preso em flagrante, sendo liberado no dia seguinte com o pagamento de fiança, usando o dinheiro que ainda possuía. Depois desse episódio, um educador social o encaminhou para outra instituição, uma espécie de filial da última em que havia ficado, que recebia os mesmos meninos e meninas em situação de rua, mas com intuito de proporcionar maior distância dos acolhidos das drogas e do tráfico, pois ficava em uma área rural.

\subsubsection{Busca de reconhecimento pelos pares}

Depois de um tempo na nova instituição, Marcos diminuiu o uso de drogas. Os profissionais do local, então, organizaram uma república, uma casa para ele e outros morarem, onde teriam que trabalhar e organizar o local, de forma mais autônoma. Mas alguns ainda usavam crack e começaram a vender objetos da casa para comprarem a droga. Outros participavam do tráfico de drogas de forma geral. Um dia, Marcos foi preso por tráfico.

Indica-se, nesse momento, outra tentativa de reconhecimento pelo grupo de pares, único grupo ao qual Marcos se sentia acolhido. Aderiu, então, às práticas desse grupo, o que incluía uso e tráfico de drogas. Ele chegou a afirmar que sua família, na verdade, eram os que tinham vivência de rua. Mas como consequência, pela primeira vez enquanto adulto, Marcos foi preso, ingressando em outra instituição, agora, do Sistema Penitenciário.

\subsubsection{Fase da Instalação}

\subsubsection{Da humilhação à humildade : assumindo a própria vergonha}

Novamente, inserindo-se em um novo grupo, Marcos apresentou um conflito entre a busca de reconhecimento social e a busca de reconhecimento entre os pares, como ocorreu quando ingressou na instituição de acolhimento para adolescentes e jovens em situação de rua. E o grupo de pares, nesse momento, representava um grupo que, concretamente, não 
estava integrado à sociedade. Depois que entrou no sistema penitenciário, esse conflito ficou evidente quando disse que ficou com vontade de trabalhar depois que saísse, pois, para ser alguém na vida, segundo ele, somente sendo um trabalhador. Iria comprar uma casa e um carro, além de constituir uma família. Gostaria, assim, de mostrar para todos os que não haviam acreditado nele, que havia conseguido alcançar as expectativas sociais em relação a ele. Também gostaria de mostrar essas conquistas a Zilma, para que ela se arrependesse de não ter ficado com ele. Uma forma de garantir a permanência dessa vontade ocorreu quando ele passou a frequentar os encontros religiosos dentro do presídio, pois os que participavam desses momentos eram aqueles que não queriam fazer o que chamou de coisas ruins no local.

Mas ao mesmo tempo, estar preso implicava estar em alerta constante, pois o medo de sofrer algum tipo de violência vinda de outro interno, era permanente. Depois que saiu da cela provisória, foi para uma ala onde não ficou à vontade, pois os demais internos que ali estavam eram traficantes por opção e não por serem pobres como ele, e precisarem de dinheiro. Solicitou que fosse transferido e, assim, Marcos foi para outra ala, onde só estavam traficantes pobres como ele, mais humildes, como classificou.

Assim como quando ficou na cela provisória, era preciso pagar aos demais para dormir na cama ou no chão. Como a última opção era mais barata, sempre dormiu no chão. Mas para conseguir dinheiro, a única opção era fazer faxina da cela e lavar as roupas de todos os que estavam em sua cela. Foi muito humilhado por isso, mas não tinha outra alternativa. Mas Marcos reforçou que se manteve humilde e, com isso, começou a ser respeitado pelos demais internos. Um ponto a ser ressaltado é o significado das palavras humilhação e humildade. Segundo o Dicionário Houaiss da Língua Portuguesa (Houaiss \& Villar, 2009), humilhar alguém é torná-lo desacreditado, rebaixá-lo, submetendo-o. Então, mais uma vez, Marcos viveu uma situação em que era subjugado pelo outro, em que suas fraquezas e dificuldades ficaram evidentes, numa relação de forças desigual da qual não poderia se 
desvencilhar. Mas ele reagiu dessa vez, mostrando-se humilde como estratégia e, com isso, conseguiu respeito dos demais. O significado da palavra humilde ajuda a compreender essa dinâmica. Ser humilde é a virtude do reconhecimento das próprias limitações, sendo submisso ao outro (Houaiss \& Villar, 2009), o que indica, enquanto virtude, o que se espera socialmente do outro quando esse está numa posição desfavorável. Assim, para conseguir um lugar no novo grupo onde Marcos estava, ele, pela primeira vez em sua trajetória, assume suas fraquezas frente ao outro, submetendo-se e assumindo assim, a vergonha sentida pela inferioridade. E submissão refere-se ao "ato ou efeito de submeter(-se) a uma autoridade ou lei” (Ferreira, 2010 p. 714), aceitando seu estado de dependência e sujeitando-se. Tem-se assim, o início da fase da instalação de uma situação de desinserção social de fato, em que o sujeito se submete ao outro, não vendo outra alternativa, internalizando uma autoimagem negativa (Blondel, 1994).

Então, percebe-se que a única alternativa que Marcos viu como eficaz, para se inserir, era finalmente assumir a vergonha de não ser tal qual era esperado pelo outro. Não havia mais a possibilidade de evitar isso, pois inserir-se naquele grupo era uma questão de sobrevivência. Todas as estratégias utilizadas anteriormente somente haviam reforçado o desprezo do coletivo em relação a ele. Mas ali, todos estavam em desvantagem em relação à aceitação social, então talvez pudesse mudar sua postura. Então, como ele precisava ser aceito nesse grupo, ele inverteu sua estratégia: admitiu ser inferior, ser inadequado. Ao ser humilhado, ele aceitou essa ação, e de forma humilde, procurou estabelecer algum vínculo com os integrantes da cela. Ele legitimou o olhar do outro que o humilhava. Numa relação humilhante, o humilhado sente ódio e raiva por se sentir impotente para sair dessa relação desigual de forças. Mas, numa postura humilde, ele afirmou que não expressou o ódio e a raiva sentidos, o que era bem visto pelos demais. A fim de reforçar sua posição inferiorizada, contou sua história de vida e como não conseguia sair do "mundo do crime", pois estava destinado a ser o 
pior "vagabundo". Todos caracterizaram sua história como triste mas, diferentemente de quando estava na segunda instituição de acolhimento, quando também qualificaram sua história como triste, os companheiros de cela não tiveram pena dele. E ao não sentir pena, não viram sua história somente como negativa, mas passaram a ajudá-lo e diziam que havia esperança, porque sua vida poderia ter sido ainda pior. Então, de alguma maneira e de forma paradoxal, ao se humilhar, ao assumir suas limitações, conseguiu ser reconhecido pelo grupo por não querer ser maior que ele, mas por manter-se inferior e submetido aos seus componentes. Então Marcos, ao mostrar sua inferioridade, submeteu-se a ela e se adaptou (Gaulejac, 2006k). Com isso, ele ficou cada vez mais distante de alcançar as exigências necessárias para ser reconhecido socialmente, pois como se assumiu inferior, não teria, então, as qualidades necessárias para conquistar seu espaço enquanto trabalhador honesto.

Mas ele aprendeu algo mais com essa experiência: é preciso ter dinheiro para tudo na vida; caso contrário, não se é nada. Para ter um lugar na cela em que estava, literalmente, ele precisava de dinheiro. E ele conseguiu a quantia necessária, mesmo que isso custasse o reconhecimento da própria vergonha, que até aquele momento, ele procurava se desvencilhar. Com o dinheiro em mãos, ele foi alguém, mesmo que estivesse submetido ao grupo e ao funcionamento da instituição. Era uma questão de sobrevivência. Ao mesmo tempo, Marcos apresentava um conflito fundamental, entre aceitar seu limite e entre estar em uma situação injusta, na qual era humilhado pois outras pessoas, não ele, viam-no como inferior.

\subsubsection{Entre a sujeição e a adrenalina}

Após dois meses e meio, Marcos foi liberado da prisão, por falta de provas relacionadas à denúncia de tráfico de drogas. Ele levou uma semana para se recompor no meio social novamente, pois ficava o tempo todo em estado de alerta, com medo de que alguém pudesse lhe fazer algo ruim, como quando ficava no presídio. Mas assim que foi 
liberado, Marcos foi acolhido por algumas pessoas que haviam trabalhado como educadores na instituição para adolescentes e jovens em situação de rua, na casa deles, como se ele fosse da família. Ele ainda tinha a quantia de $\mathrm{R} \$ 3.200,00$, que recebeu pela morte da mãe, emprestando esse valor para as pessoas com quem estava morando, e recebia de volta, mensalmente, $\mathrm{R} \$ 100,00$.

Ele ficava à vontade com essas pessoas pois, como elas tinham experiência com meninos e meninas em situação de rua, conheciam o sofrimento de quem não tinha mãe nem pai, de quem foi criado sozinho sem ter alguém que pudesse se interessar pelo que sentia. Para ele, quem trabalhava de forma satisfatória com esse público, tinha alguma identificação com a situação de rua, mas não sabia muito bem como isso se dava. E sua identificação com o grupo de rua ocorria pelo sentimento de abandono que tinham em comum e pelo fato de ninguém acreditar neles.

Mas ao mesmo tempo, para permanecer nessa casa, ele precisava se submeter às tarefas às quais lhe eram destinadas, o que Marcos aceitou. Diferentemente de quando morou na casa do tio, ali ele aceitava cooperar com as atividades rotineiras, ajudando, inclusive, na reforma da casa. Eles elementos indicam que ele, mesmo fora do sistema prisional, continuava a se submeter a um grupo, assumindo suas fraquezas, assumindo que precisava de ajuda, pois não tinha recursos para se organizar sozinho, para ter seu lugar garantido. Mais uma vez, ele vivenciava uma relação de dependência que favorecia que se organizasse e pudesse sobreviver coletivamente. Como indicou Gaulejac (20061), é preciso mostrar a própria vulnerabilidade para obter ajuda e proteção. Era o reconhecimento pela inferioridade. E, ao mesmo tempo, ficava com muita raiva dessa situação, pois sabia que realmente, não se importavam com ele, mas ele não expressava esse sentimento para não perder seu lugar no grupo. 
Outra estratégia que repetiu do presídio, foi integrar um grupo religioso. Sempre que Marcos ficava com vontade de se vingar de quem o denunciou para a polícia, fazendo com que ficasse preso, ele ia para a igreja e ouvia que Deus estava livrando da morte aos que ali estavam, e isso o deixava aliviado.

Mas o conflito entre ser reconhecido socialmente e ser reconhecido pelos grupos que não são bem vistos pela sociedade, como um grupo de traficantes de drogas, persistia. Ele sabia que teria que trabalhar para conseguir "ser alguém". Então, se ele estava buscando ser alguém, era porque ainda não o era. Uma fala ilustra bem esse dilema: sabia que tinha que trabalhar, mas existia algo no seu caminho que o impedia de continuar nessa trajetória, puxando-o para um outro caminho. Por exemplo, ele conseguiu alguns empregos mas não permanecia por muito tempo, pois a relação com a chefia era sentida como humilhante, como se reforçasse sua inferioridade social. E isso era insuportável, fazendo-o deixar o trabalho. Nesse sentido, era mais fácil conseguir dinheiro de forma ilícita, já que nesse grupo conseguia algum tipo de respeito. A questão então continuava sendo a busca do reconhecimento. E em um mundo caracterizado pela hipermodernidade, onde o que é valorizado socialmente é a excelência (Aubert, 2012), o olhar do outro que remete ao sujeito sua insuficiência e vulnerabilidade, é insuportável, principalmente quando esse olhar atinge a autoestima daqueles que já estão com ela bastante ferida.

Marcos ilustrou esse dilema do reconhecimento quando disse que existem dois tipos de consideração. Um, que tinha antes, ocorria quando era traficante de drogas e sentia muita adrenalina por isso. Outro, o que recebia naquele momento, era o reconhecimento enquanto trabalhador, mas nesse caso não sentia alguma adrenalina. O trabalho de reforma da casa onde morava era visto pelos "bandidos" do local com admiração, como sendo um sinal de força. Mas "sentir a adrenalina" era uma forma de Marcos se sentir vivo, o que não ocorria quando 
estava trabalhando. Se de um lado ele poderia ser reconhecido socialmente, do outro, ele poderia se sentir vivo.

Em relação ao filho, não tinha ido mais visitá-lo, mas gostaria de contar sua história para ele no intuito de mostrar o que não deu certo e evitar que ele cometesse os mesmos erros. Tinha vontade de morar com ele, buscá-lo na escola e ter dinheiro para se divertir com ele e com a mãe dele. Queria ter uma vida típica de uma família integrada na sociedade, que trabalha, tem dinheiro, tem filhos e usufrui de momentos de diversão.

Sobre sua família de origem, foi visitá-la em um fim de semana, mas não tinha vontade de morar com ela. Depois desse dia, suas tias passaram a ligar para ele com frequência, para saber como ele estava, convidando-o para passar o Natal com eles. Mas Marcos recusou e participou da ceia com os meninos e meninas em situação de rua, na última instituição de acolhimento onde Marcos havia ficado. Como ele já havia indicado, eles são sua família. Mostrou para eles que estava se esforçando por meio do trabalho para ser alguém. Ao mesmo tempo, sobre a prisão, não tinha mais medo dela, mas disse que não foi bom ter sido preso inocentemente. Gostaria de voltar para lá, mas por algo que realmente fizesse. Novamente, falando como se houvesse sempre algo que o tirasse do caminho do trabalho honesto e o conduzisse a quebrar regras e normas sociais.

Acreditava que o mundo girava e, assim, se em uma hora a pessoa estava em uma situação ruim, em outra poderia melhorar. E essa representação indica que havia uma esperança em Marcos de que ele ainda poderia ser reconhecido socialmente, mas ele mesmo não tinha certeza de que isso iria acontecer. Principalmente depois que assumiu a própria vergonha de ser humilhado e desprezado pelo outro, inúmeras vezes, internalizando uma autoimagem negativa. Disse que já poderia ter se matado por meio do uso de drogas, mas, no fundo, sabia que sua vida não era só "sofrer, sofrer e sofrer para, no final, morrer". Assim, 
ficava entre se submeter ao outro, ao social, tornando-se sujeito, ou ficar de fora e sentir a adrenalina, sentir-se vivo num grupo excluído, porém, sem reconhecimento social.

Ao expressar sua história de vida para esta pesquisa, ele afirmou que por mais que ele se lembrasse de situações ruins, pode identificar também, aspectos positivos de sua vivência, talvez, indicando a Marcos como ele não era somente vítima de uma circunstância, mas que ele tinha feito escolhas a partir do que foi vivenciando. Tal situação fica clara ao se observar como ele foi construindo estratégias de respostas ao longo dos anos.

\subsubsection{Síntese}

Ao longo da primeira análise temática da história de vida de Marcos, que teve como foco estratégias de respostas em processo de desinserção social, observa-se que ele fez uso de várias estratégias ao longo do tempo, conforme apresenta-se a seguir:

\section{Tabela 1}

Nível Temático 1: estratégias de respostas em processo de desinserção social

\begin{tabular}{cc}
\hline Fase & Estratégias de Respostas \\
\hline $\begin{array}{c}\text { Fase da } \\
\text { Resistência }\end{array}$ & $\begin{array}{c}\text { Evitando situações humilhantes } \\
\text { Agredindo o outro para se defender } \\
\text { Transferindo a culpa }\end{array}$ \\
& Buscando reconhecimento por meio de relações familiares \\
Autopunição
\end{tabular}


Fase da Instalação

Da humilhação à humildade: assumindo a própria vergonha Entre a sujeição e a adrenalina 


\subsection{NÍVEL TEMÁTICO 2: REPRESENTAÇÃO IMAGINÁRIA A PARTIR DOS DESENHOS}

Em relação à análise temática da história de vida de Marcos, essa também foi realizada com foco em outro tema: a representação imaginária de elementos de sua trajetória a partir dos desenhos elaborados por ele, durante a entrevista. Nesse sentido, foram consideradas três perspectivas: 1) a de Marcos; 2) a que emergiu do diálogo entre o participante e a pesquisadora sobre os desenhos e, 3) ainda, a da pesquisadora, a partir da nível descritivocronológico e da análise temática sobre estratégias de respostas de seu processo de desinserção social. Essa análise considerou que as entrevistas foram realizadas em dois momentos: um primeiro quando Marcos era adolescente e um segundo momento, quando ele já havia ingressado na idade adulta.

$\mathrm{Na}$ primeira entrevista, Marcos fez vários desenhos enquanto contava sua história de vida e, assim que terminava, amassava e jogava o desenho no lixo. Esse ato ocorreu diversas vezes ao longo de todo o encontro, que durou cerca de uma hora e meia. Ele não quis comentar porque agia dessa forma, mas indicou que o que produzia não era bom o suficiente e precisava ser descartado. Essa ação também pode fazer referência ao fato de que, muitas vezes, associava a si mesmo a um lixo, o que era reforçado pelos acolhidos da primeira instituição que sempre o lembravam que sua mãe o havia abandonado em uma lata de lixo. De qualquer forma, o fato de ele desenhar durante a entrevista facilitou que pudesse expressar diversos momentos difíceis que vivenciou. Como ele afirmou após alguns encontros, ele não teria conseguido contar sua história "de cara limpa", ou seja, olhando para a pesquisadora e narrando, sem qualquer mediação. 


\subsubsection{Primeiro momento das entrevistas}

\subsubsection{Desenho 1}

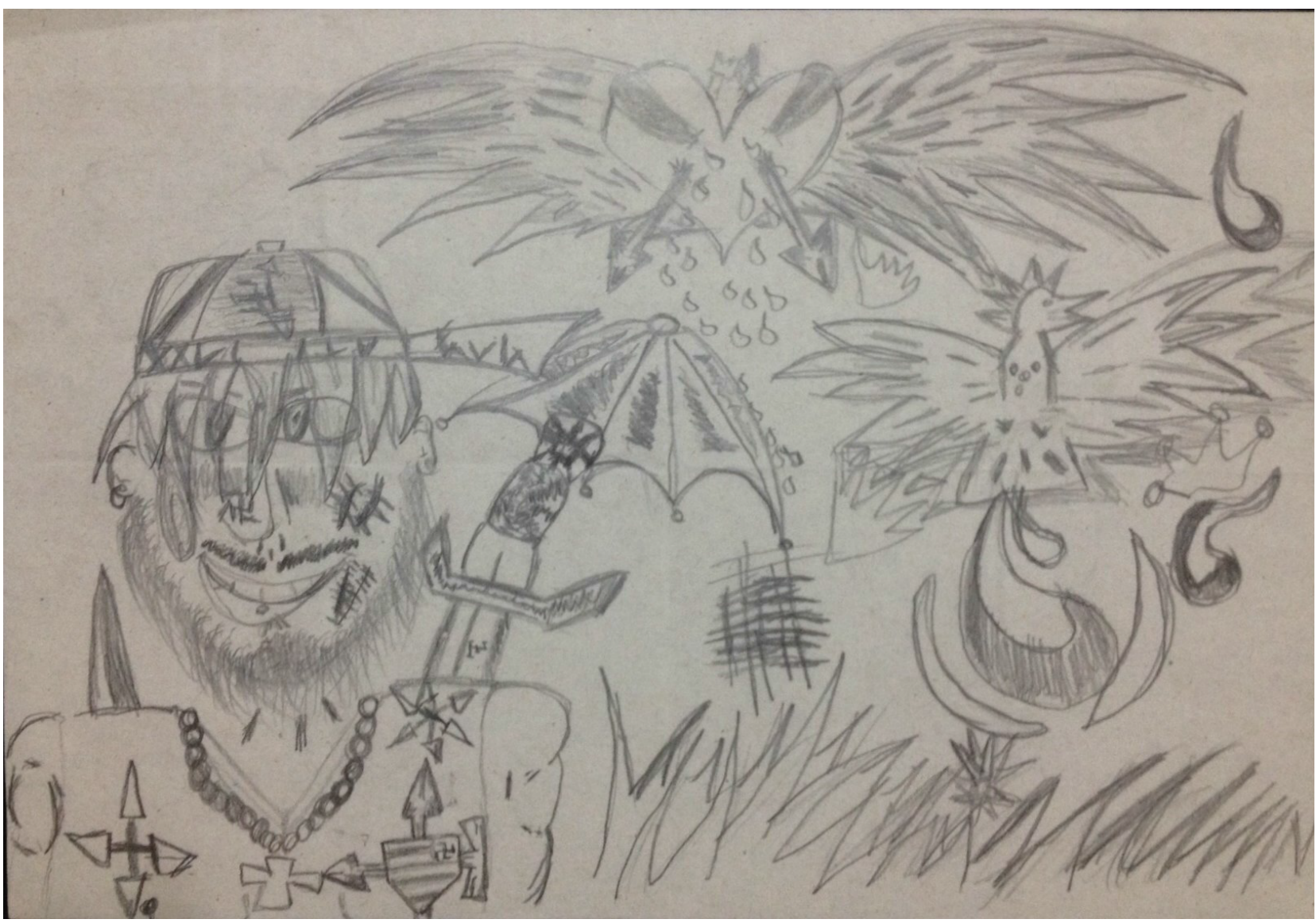

Figura 1 - Desenho 1

Nos dois encontros seguintes, Marcos iniciou a elaboração de um desenho, deu-o para a pesquisadora guardar e o concluiu na entrevista seguinte. Esse gesto pode ter indicado a concretização de um vínculo de confiança entre ele e a pesquisadora, no sentido de que ofereceu sua produção para ela guardar. Também pode denotar um sentido de continuidade, onde procurou resguardar que haveria outro encontro para continuar a narrar sua vivência. De alguma forma, Marcos estava indicando que aquele espaço estava sendo acolhedor o suficiente para que ele contasse suas experiências que continham angústia e sofrimento. Além 
do mais, pode ter percebido que tinha como produzir algo que não merecesse ser descartado e que tinha algum valor.

O desenho um foi elaborado com traços fortes, a lápis, e indicava tanto elementos de força, a partir das imagens de um guerreiro e de armas, quanto de aspectos que faziam alusão a uma fragilidade afetiva, representada por um coração com asas, mas que foi perfurado duas vezes e sangrava. Marcos não quis comentar sobre o desenho, mas pela sua história de vida, sugere-se a coexistência entre o mostrar-se forte e guerreiro frente às adversidades, ao mesmo tempo em que sofria e se angustiava com essas situações.

\subsubsection{Desenhos $2,3,4,5,6$ e 7}

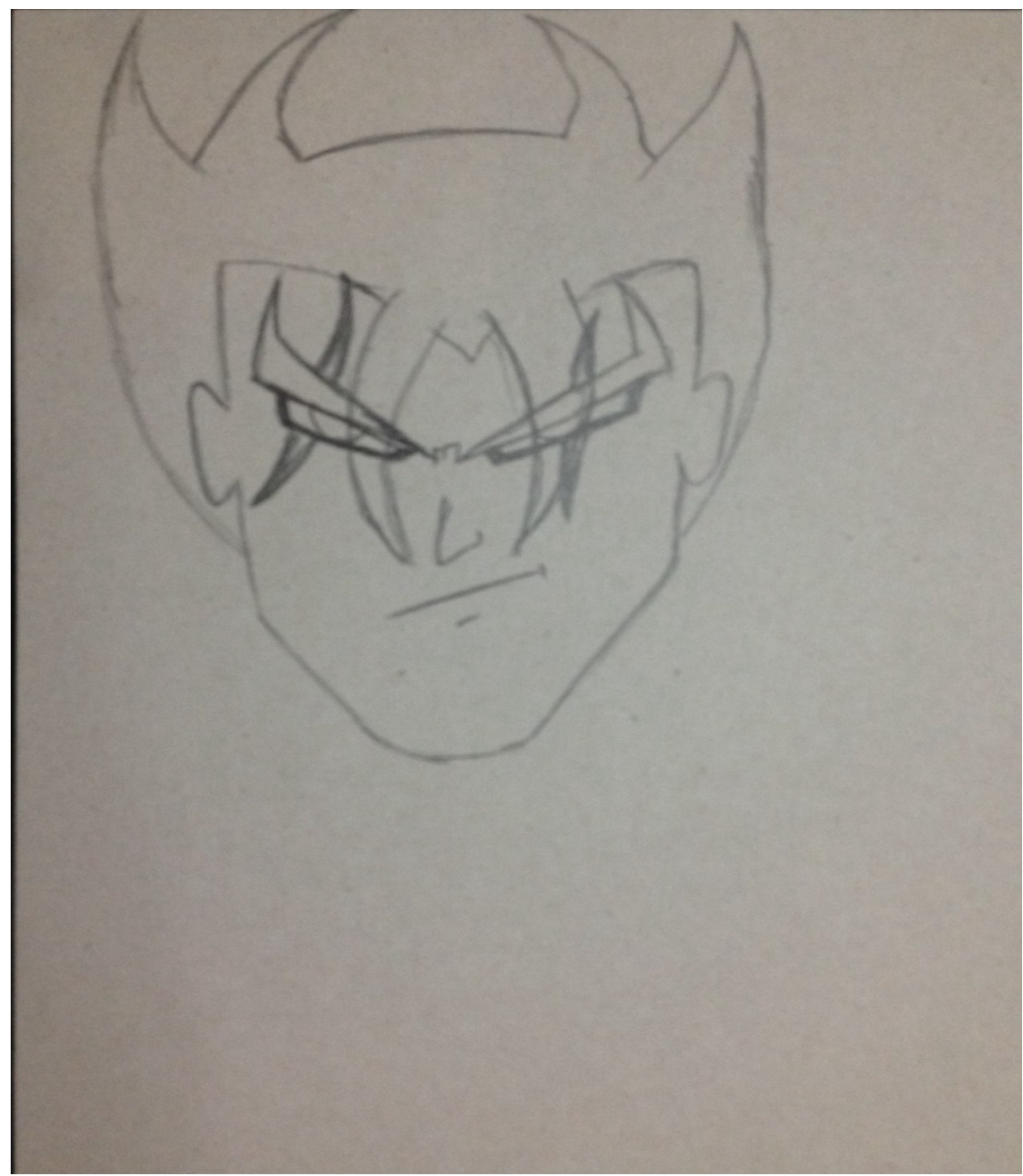

Figura 2 - Desenho 2 


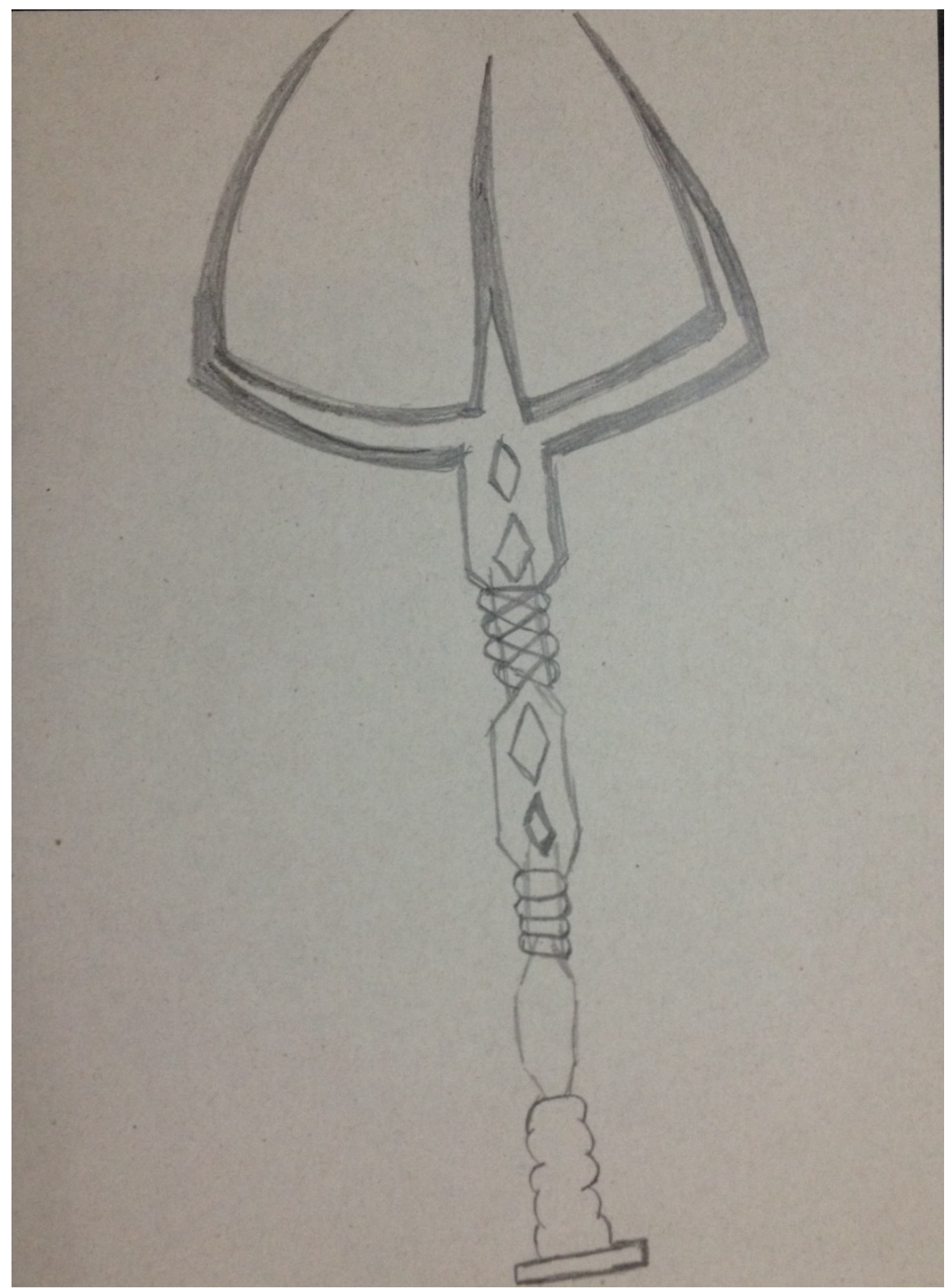

Figura 3 - Desenho 3 


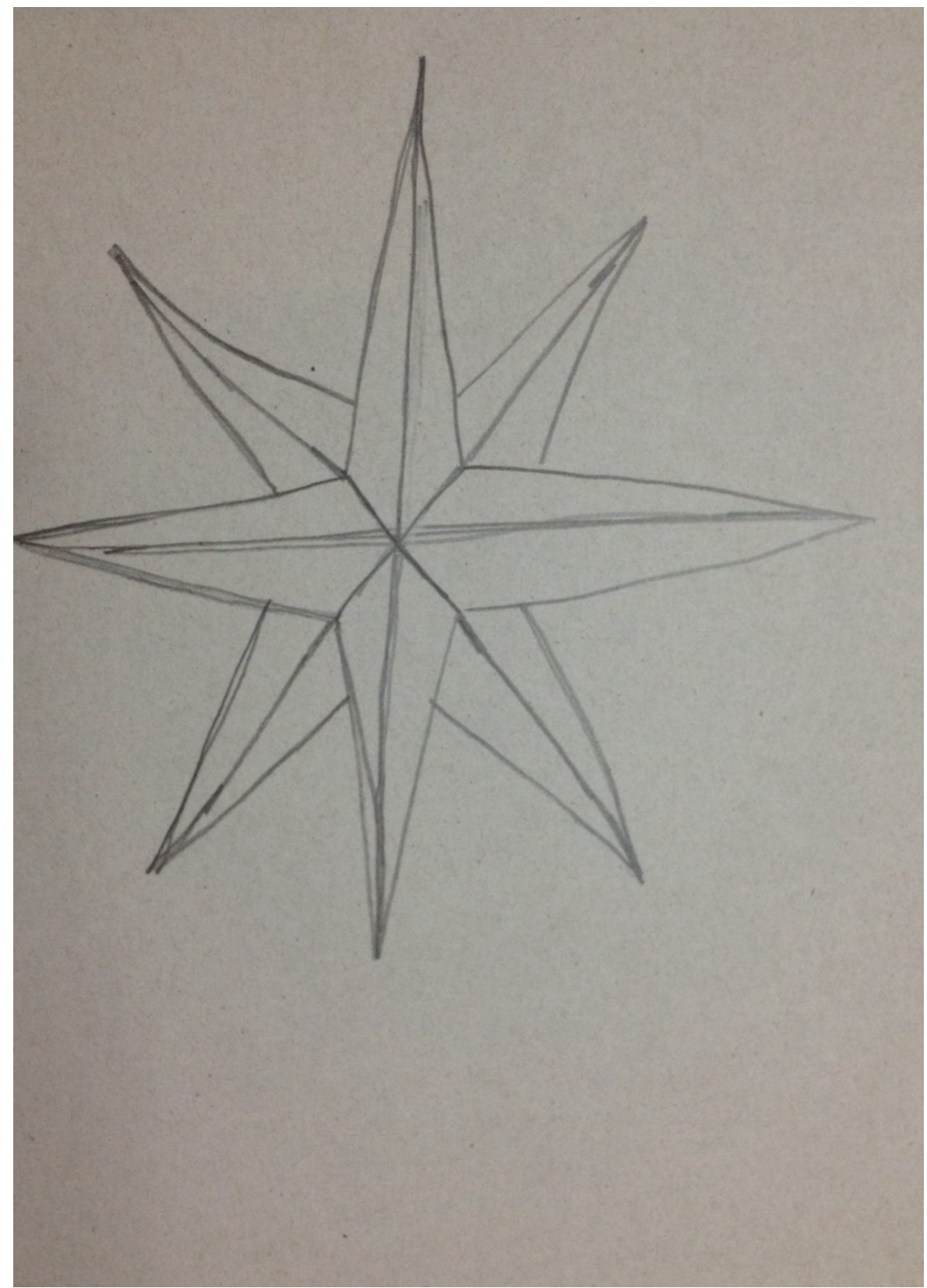

Figura 4 - Desenho 4

Em relação aos desenhos 2 a 7, Marcos os produziu em um único encontro e não comentou sobre seus conteúdos. Assim, a pesquisadora buscou elaborar um significado a partir da história de vida narrada por ele. Diferente do primeiro desenho, que continha várias informações em uma única página, os desenhos de 2 a 7 indicavam, cada qual, uma ilustração, indicando, de forma geral, um conteúdo infanto-juvenil. A questão da força continua a aparecer nos desenhos 2, 3 e 4, parecendo que o conteúdo dessas representações indicavam 
elementos de super-heróis de histórias em quadrinhos, como o rosto de um ninja de desenho japonês, uma espécie de lança e uma estrela, que poderiam ser tipos de armas.

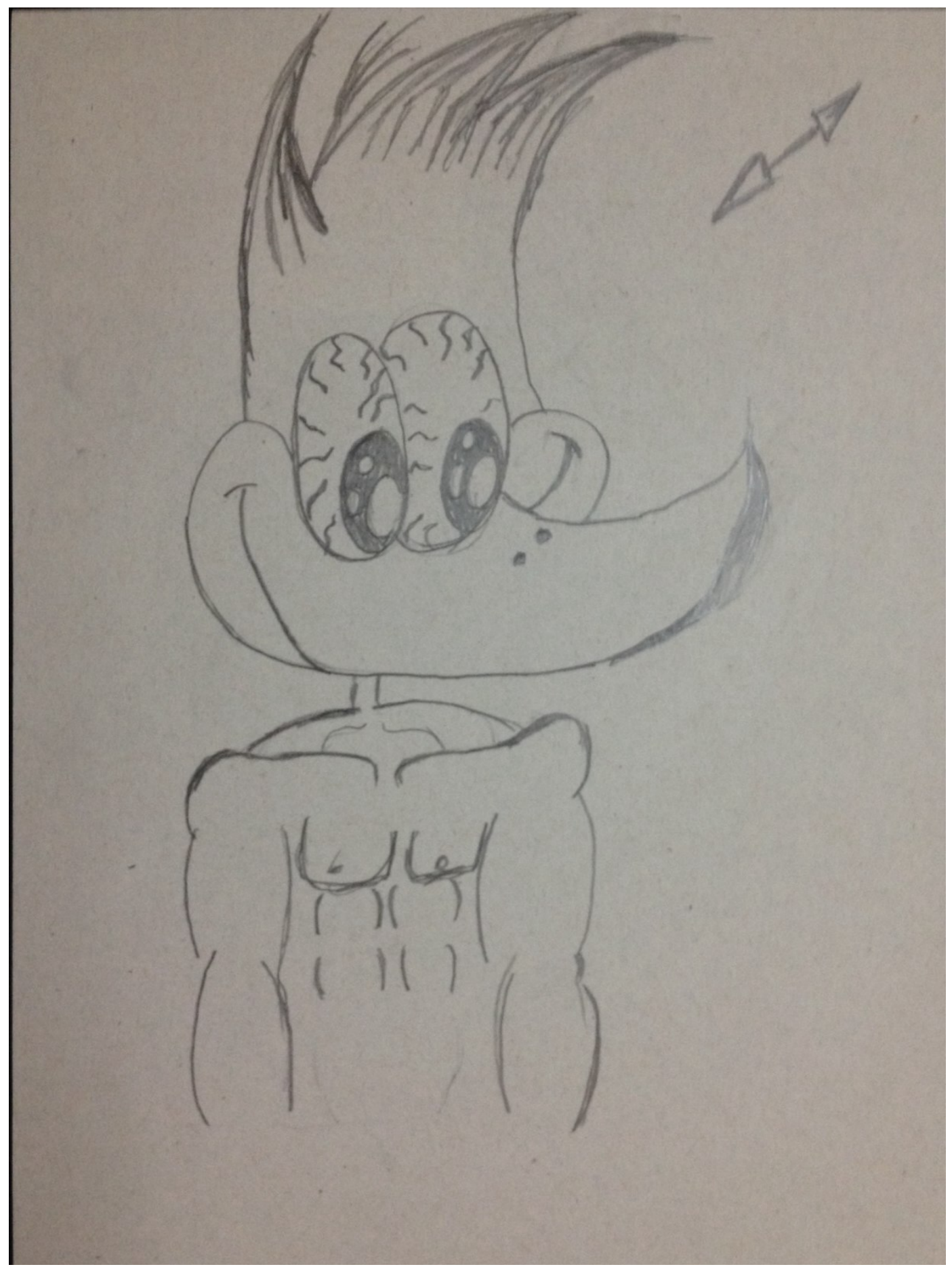

Figura 5 - Desenho 5 
O desenho 5 passa uma ideia dupla, pois Marcos desenhou uma figura de desenho animado infantil, o pica-pau, mas na sua versão, esse personagem aparece musculoso, com os olhos contendo veias aparentes, porém sorrindo. Assim, uma figura frágil e singela passa a ser forte, indicando um estereótipo do que seria uma figura que possui muita força, ao mesmo tempo que não se apresenta de forma agressiva, já que sorri. E essa representação pode indicar sua infância, pois como Marcos disse, a infância é um período onde se descobrem muitas coisas, mas na dele, ele passou por situações que fizeram esse tempo passar mais rápido.

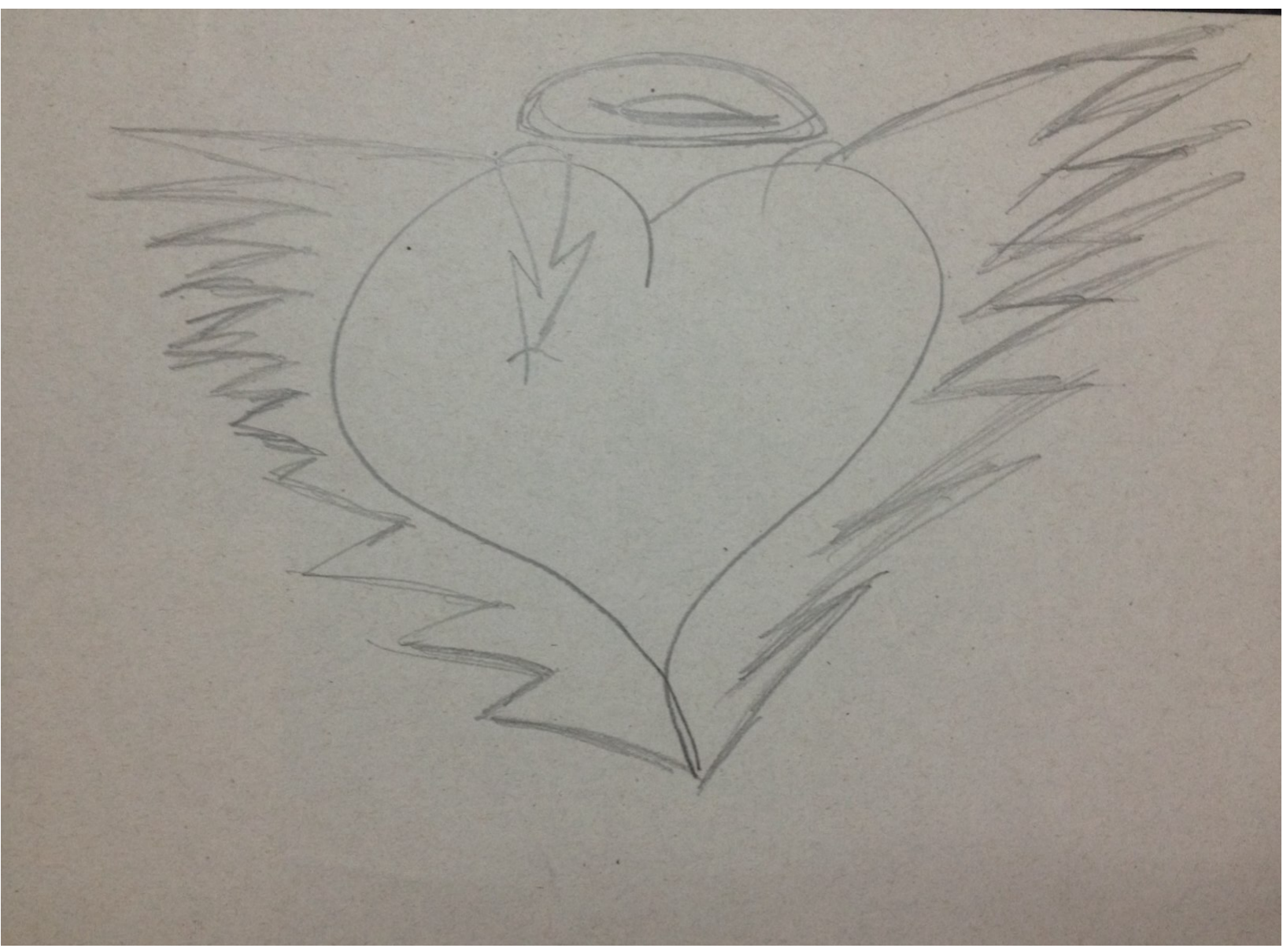

Figura 6 - Desenho 6 


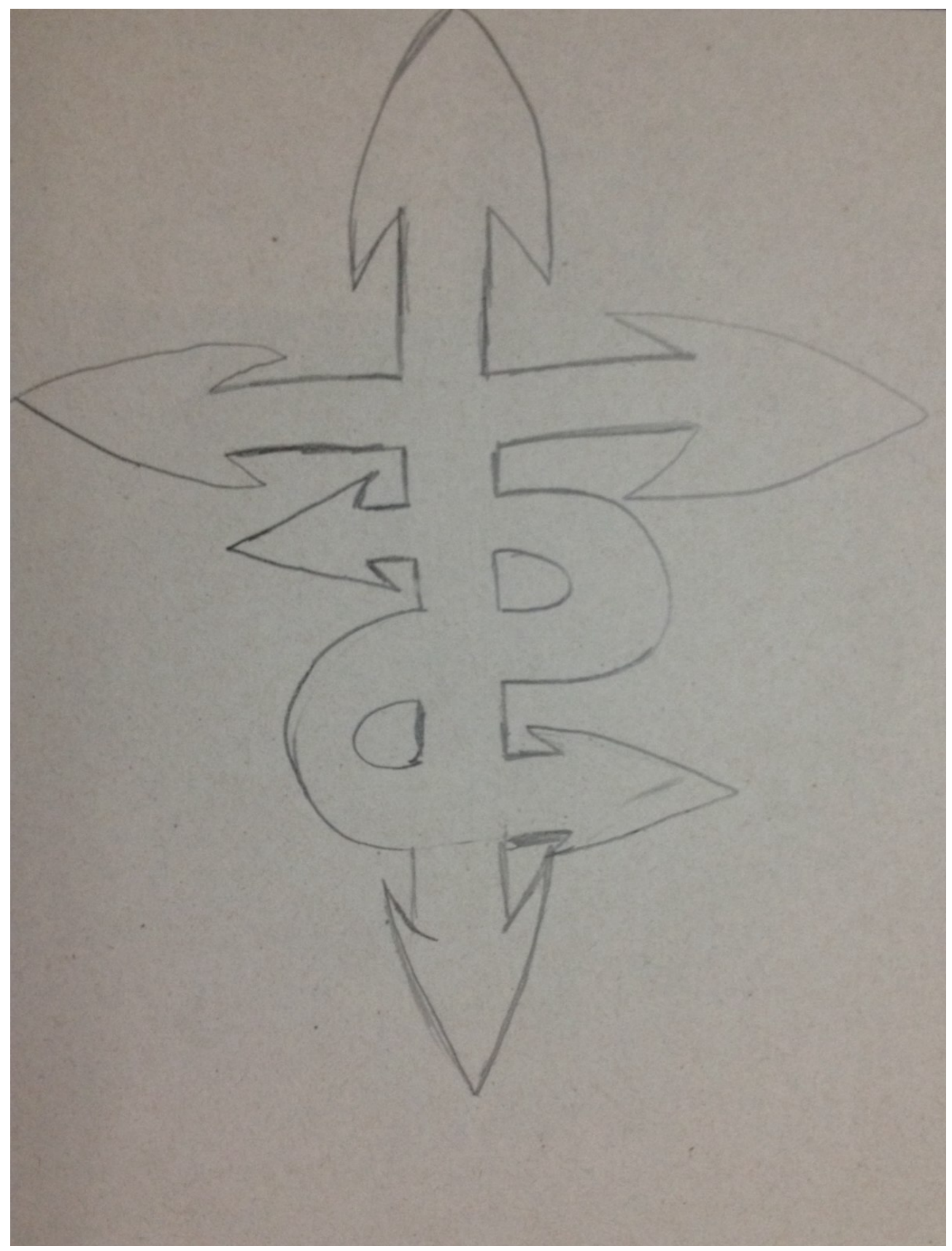

Figura 7 - Desenho 7

No desenho 6, o coração aparece novamente com asas, como no desenho 1, mas também com uma auréola, indicando um conteúdo angelical. Esse coração também é atravessado por uma seta, como se Marcos indicasse que estivesse com sua dimensão afetiva, ferida. Já o desenho 7 indica um conteúdo diferente, com sete setas que se originavam de uma mesma reta. Essa ilustração passou a impressão de haver várias possibilidades ou saídas para 
uma mesma situação, ao mesmo tempo em que não está claro qual caminho, qual direção optou-se por seguir. Em outras palavras, esse desenho indica que Marcos percebe diferentes caminhos que podem ser trilhados, mas ele não tem clareza ou ainda não havia escolhido qual percorrer.

\subsubsection{Desenhos 8, 9 e 10}

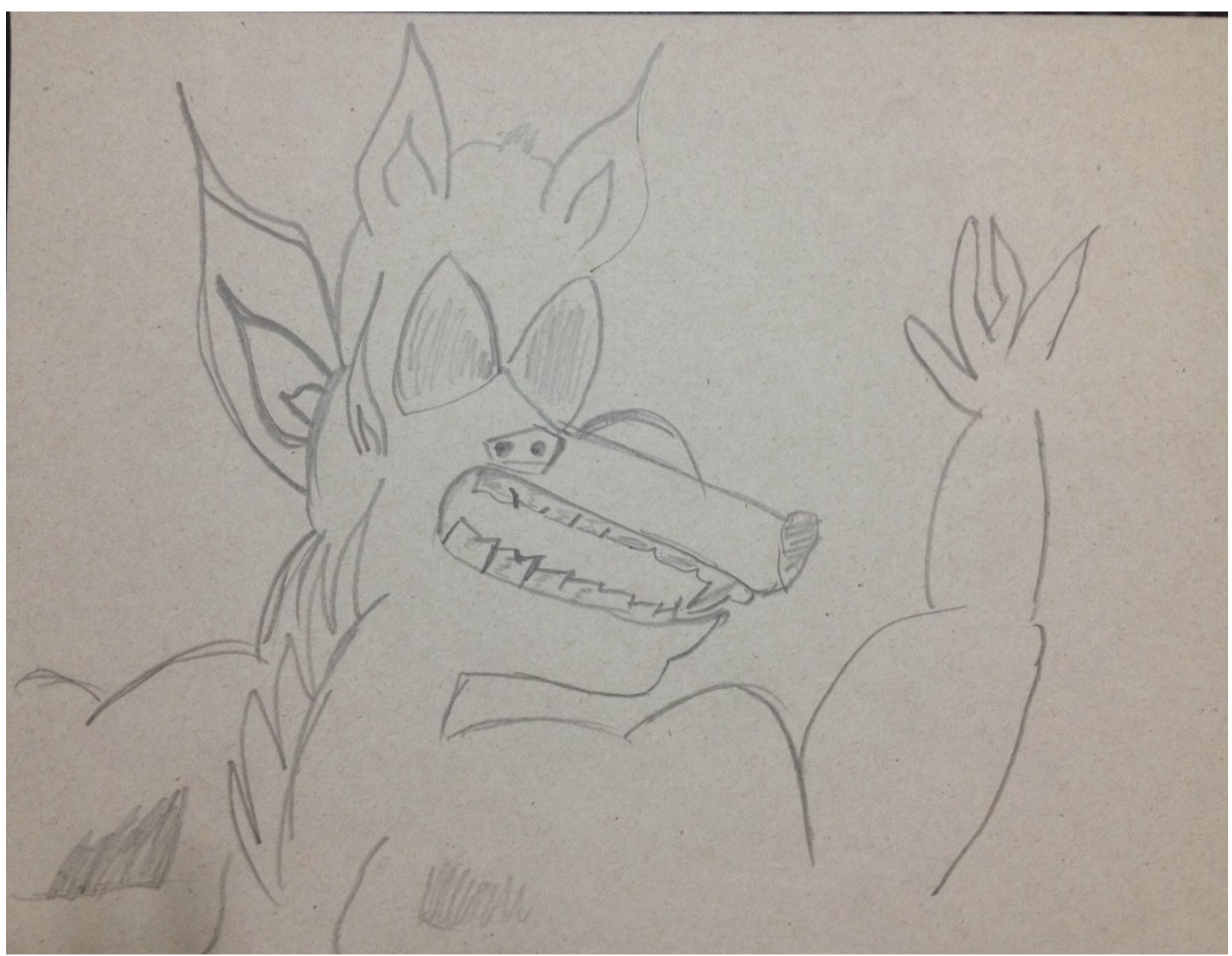

Figura 8 - Desenho 8

Os desenhos de 8 a 10 também foram feitos durante uma mesma entrevista, mas Marcos novamente não fez qualquer comentário sobre eles. Assim, no oitavo desenho, aparece uma espécie de lobo bem musculoso, que parece estar de pé sob duas patas, com a 
boca entreaberta, dentes à mostra e a pata superior esquerda para cima, passando a impressão de que estava com raiva e pronto para bater em alguém.

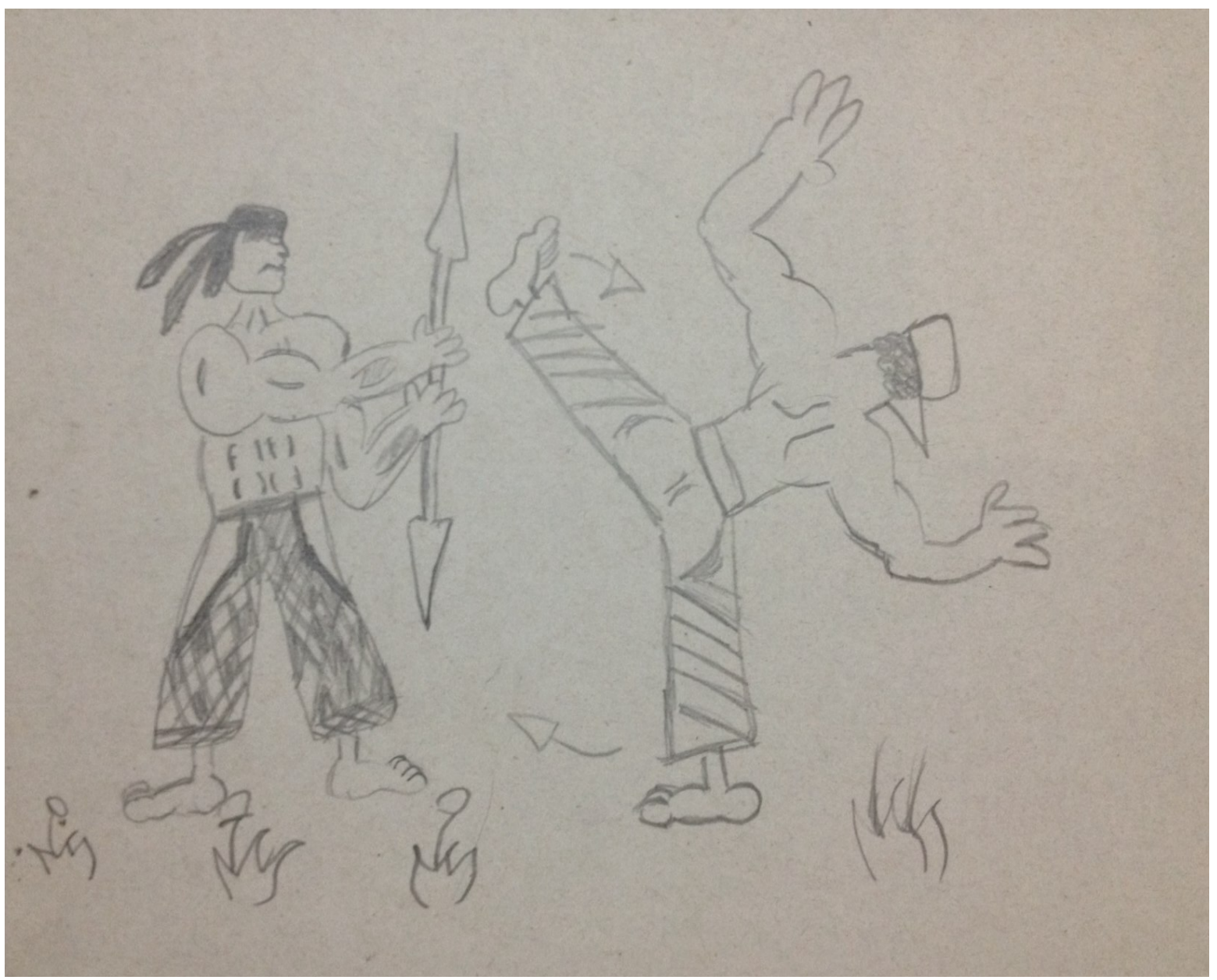

Figura 9 - Desenho 9

O desenho seguinte representa dois capoeiristas, sendo a capoeira uma modalidade que mistura dança e movimentos de luta, mas sem que os jogadores se toquem. Na elaboração de Marcos, eles aparecem bem musculosos e estão em movimento. Essa representação indica que uma situação inicialmente violenta, como uma agressão física entre duas pessoas, pode ser transformada em algo lúdico e sem que se fira o outro. 


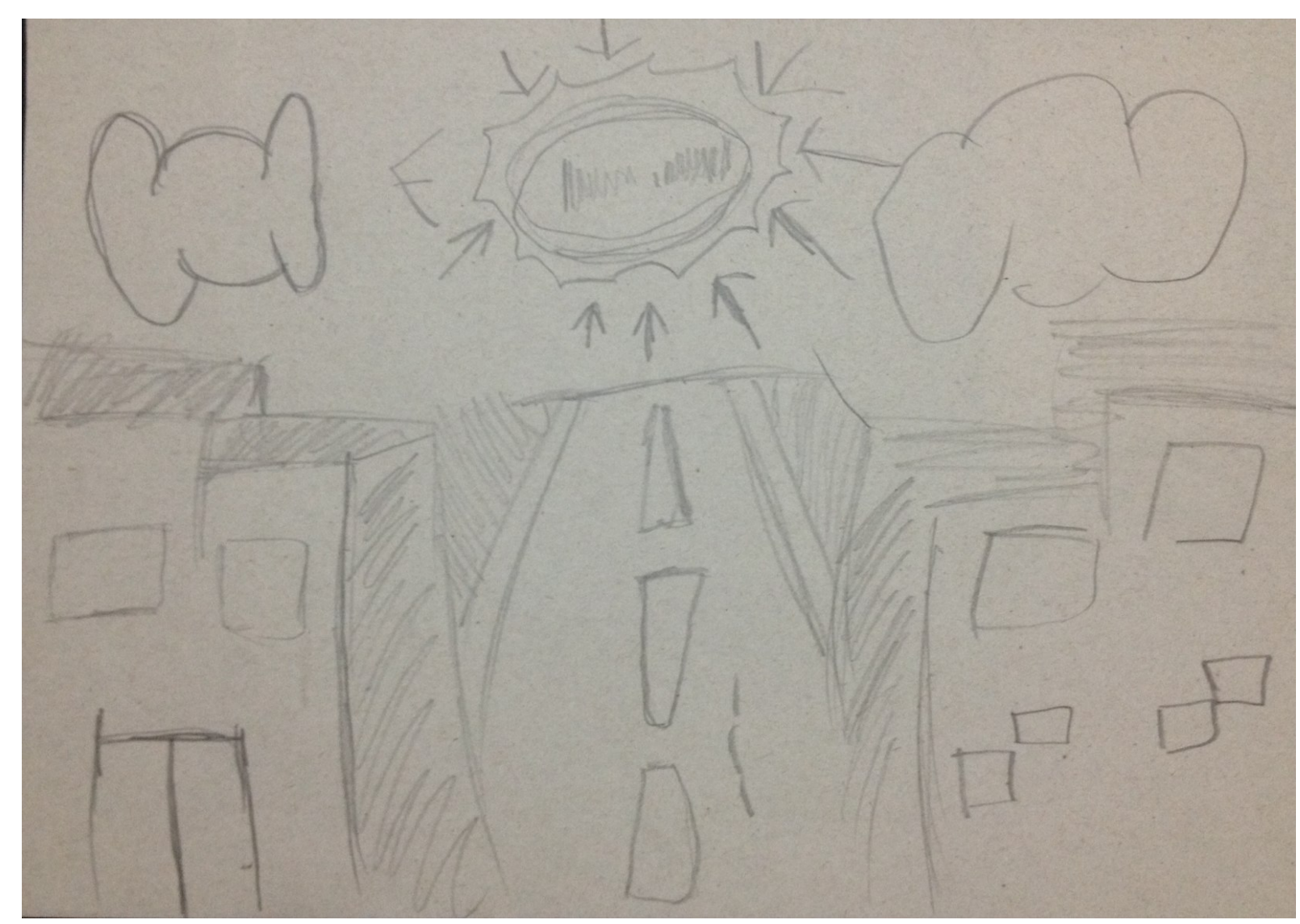

Figura 10 - Desenho 10

$\mathrm{Na}$ terceira representação do participante nesse dia, ele desenhou uma rua, em meio a dois prédios, indicando um sentido que ia para fora da cidade em direção ao sol. Não havia pessoas nem veículos nesse desenho. A partir da história de vida narrada por Marcos, essa imagem passa uma ideia de solidão e busca por algo fora do espaço onde se está, mas sem que se tenha certeza do que vai se encontrar pela frente. Nessa época, o participante estava com 17 anos, último ano para ficar em uma unidade de acolhimento para crianças e adolescentes, tipo de instituição na qual ele havia ficado desde que era bebê. Ele teria que ir para algum lugar, mas não sabia como isso de fato iria acontecer, como ele mesmo relatava. 


\subsubsection{Desenho 11}

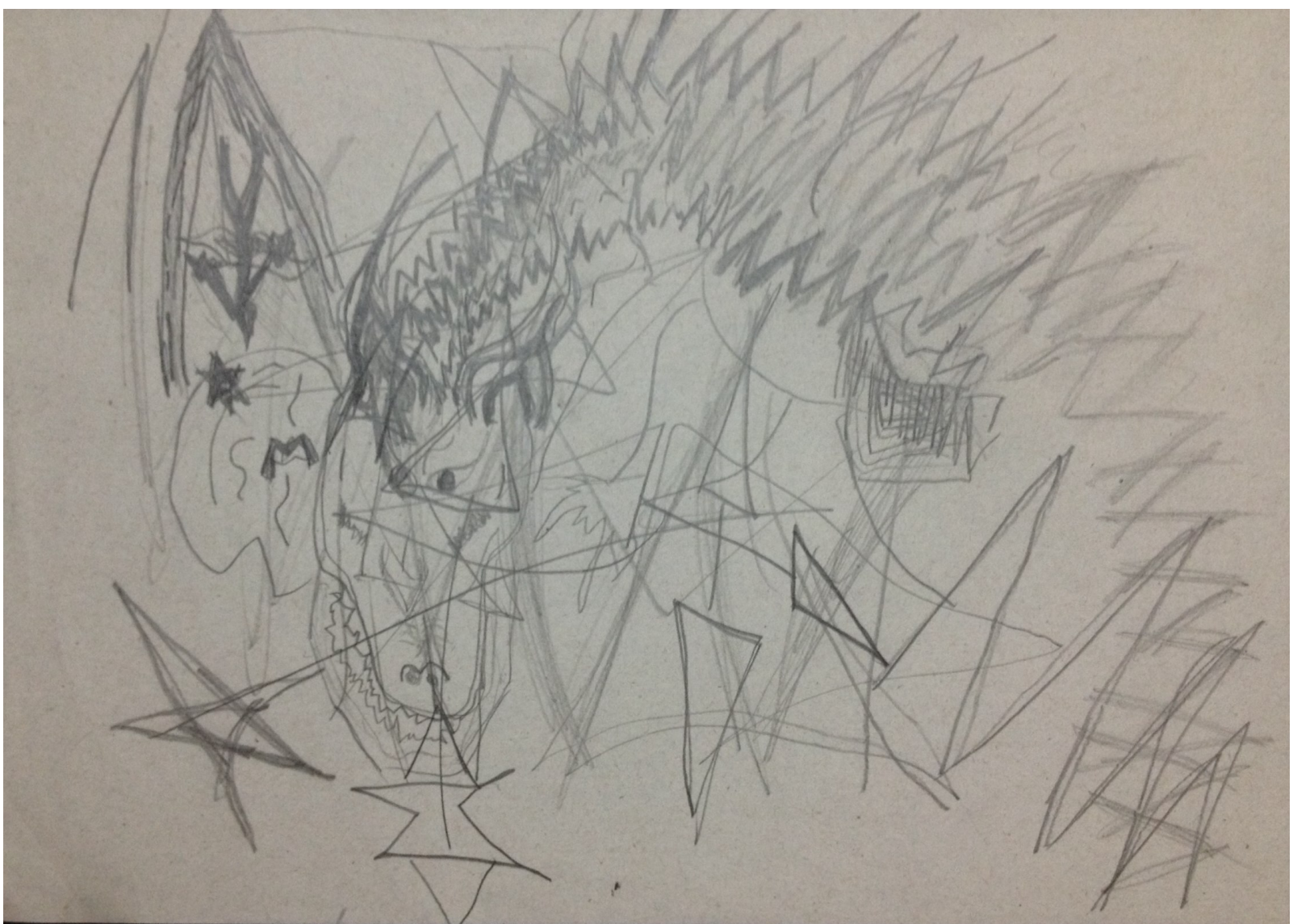

Figura 11 - Desenho 11

O desenho 11 foi elaborado no último encontro do primeiro momento das entrevistas, quando Marcos tinha acabado de ser aprovado em um projeto para receber uma bolsa de estudos e cursar a escola regular pela manhã e cursos profissionalizantes à tarde, durante 12 meses. Ele estava inseguro quanto ao futuro e de como seria sua vida como adulto, deixando nesse desenho, a ideia de confusão. Nesse dia também disse que gostaria de ser um pai mais próximo do filho, mas que teria que ter dinheiro para isso. Ele não comentou o desenho, mas elaborou uma espécie de dragão, com dentes à mostra, e fez outros traços por cima, deixando esse desenho bem desorganizado, em comparação com os anteriores que tinham uma imagem mais clara e definida. Talvez representasse insegurança e medo que estava sentindo, como ele 
mesmo disse, quanto ao seu futuro enquanto adulto, pois faria 18 anos dentro de alguns meses.

\subsubsection{Segundo momento das entrevistas}

\subsubsection{Desenhos 12, 13,14 e 15}

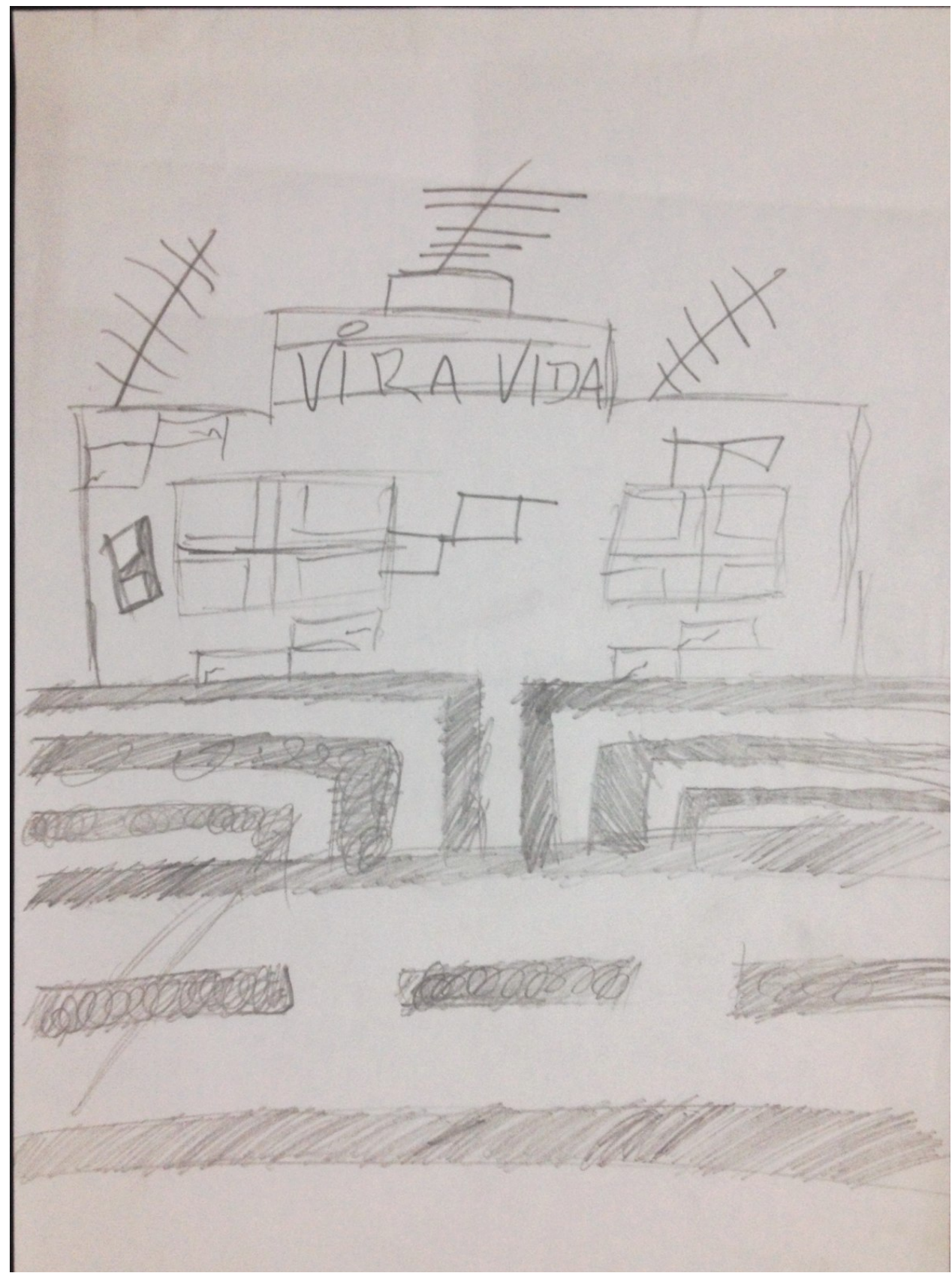

Figura 12 - Desenho 12 
Os desenhos 12 a 15 foram elaborados em um único encontro, sendo esse o primeiro do segundo momento das entrevistas realizadas para esta pesquisa. Marcos tinha saído a pouco tempo do sistema prisional, acusado de tráfico de drogas, mas por falta de provas, foi liberado após dois meses. No primeiro desenho desse dia, Marcos representou o local onde havia participado de um projeto, quando recebia uma bolsa para estudar e fazer cursos profissionalizantes, enquanto estava no Abrigo Institucional D. O primeiro momento das entrevistas terminou justamente quando Marcos iria começar a participar desse projeto.

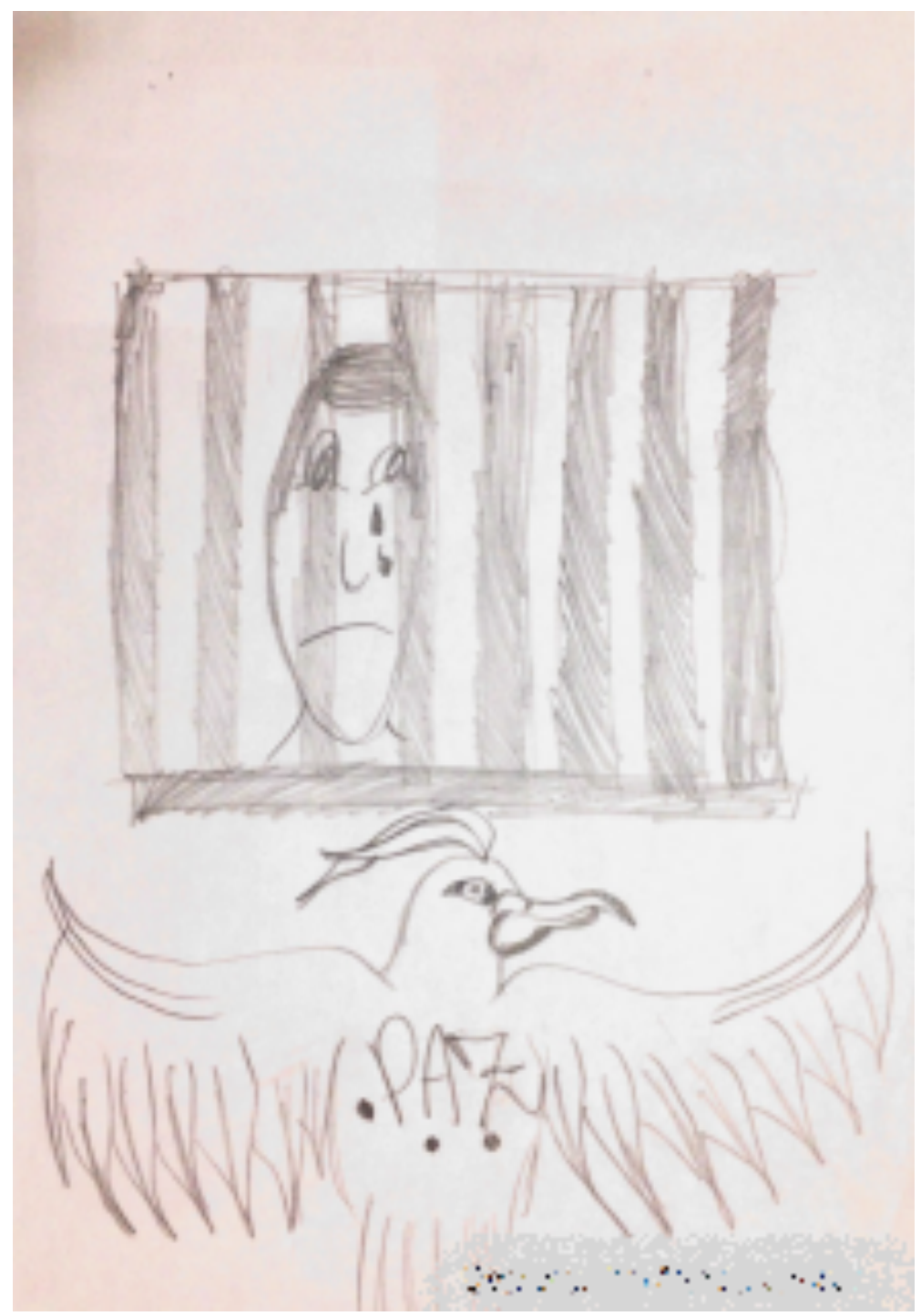

Figura 13 - Desenho 13 
Em relação ao desenho 13, ele fez o rosto de uma pessoa atrás de uma grade, chorando. Representou também, na mesma página, uma pomba marcada com três tiros e a palavra "paz.” Disse que as pessoas precisam ter paz, mas, na realidade isso não é possível, já que sempre algo vai acontecer para impedir que haja 100\% de paz. Nesse ponto, pode-se fazer uma correlação com a história narrada por Marcos. Durante toda sua trajetória, ele indica um dilema entre ser reconhecido pela sociedade em geral, ou reconhecido pelo grupo de pares, grupo esse que está sempre envolvido com uso e tráfico de drogas, roubos e outros crimes. A paz pode indicar, nesse desenho, a vontade de manter distância de atos ilegais e a dificuldade em fazê-lo, representado por tiros e uma pessoa presa, que fica triste por não ter conseguido evitar ir para a prisão.

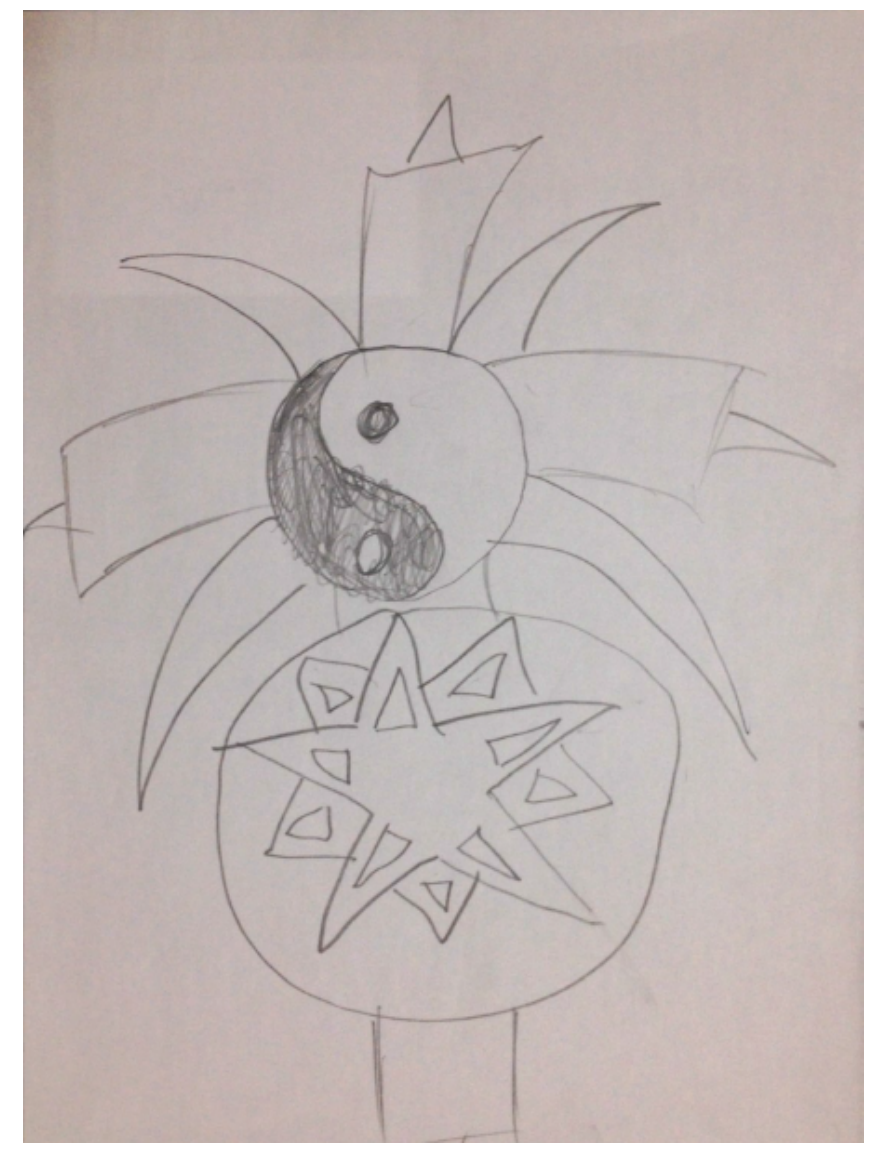

Figura 14 - Desenho 14 
Já no desenho 14, segundo Marcos, ele representou o bem e o mal, a partir do símbolo chinês Yin Yang. Também fez uma estrelinha, uma bola e uma cruz. Segundo ele, fez esse desenho somente porque não estava fazendo nada enquanto falava. Interessante o comentário de Marcos sobre o "não estar fazendo nada", referindo-se ao momento em que estava contando sua história de vida. Parece que fazer algo está relacionado sempre a uma ação concreta, como a confecção de desenhos. A fala não é vista como uma ação e, talvez por isso, não é valorizada pelos adolescentes nos atendimentos dos profissionais das unidades de acolhimento. Para eles, um atendimento realizado somente por meio da linguagem falada não representa uma ação, já que não há uma produção concreta de algo. Nesse ponto, pode-se indicar que as intervenções das equipes no contexto do acolhimento institucional precisam de um mediador, um suporte concreto para que o adolescente consiga compreender o trabalho da equipe como algo a ser valorizado. Afinal, como afirmou Marcos, somente falar é "não fazer nada". Sobre o desenho 15, mostra espinhos, flores e rosas, uns sobre os outros. Marcos disse que as rosas eram muito bonitas, mas sempre vinham acompanhadas de espinhos também.

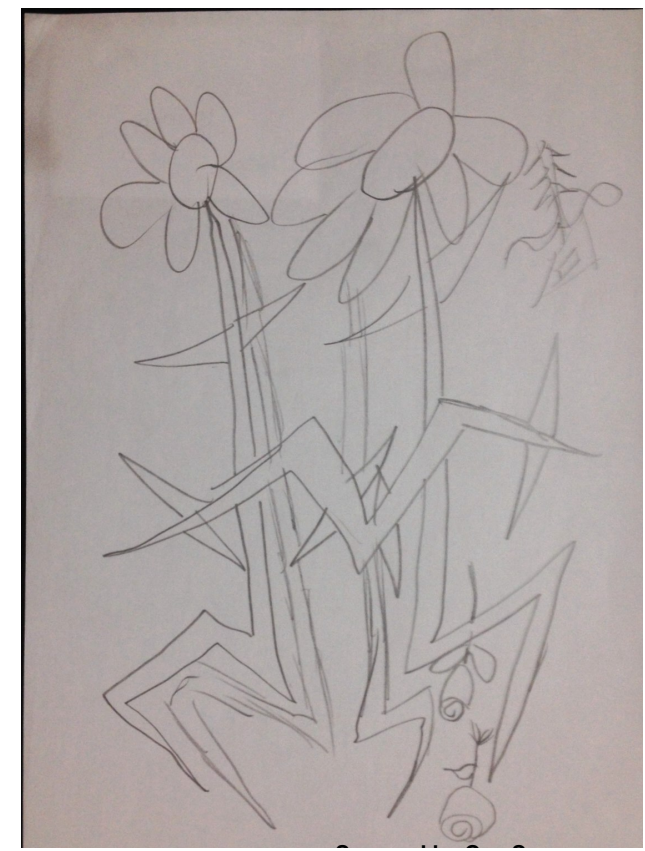

Figura 15 - Desenho 15 
5.3.2.2 Desenhos 16, 17, 18 e 19

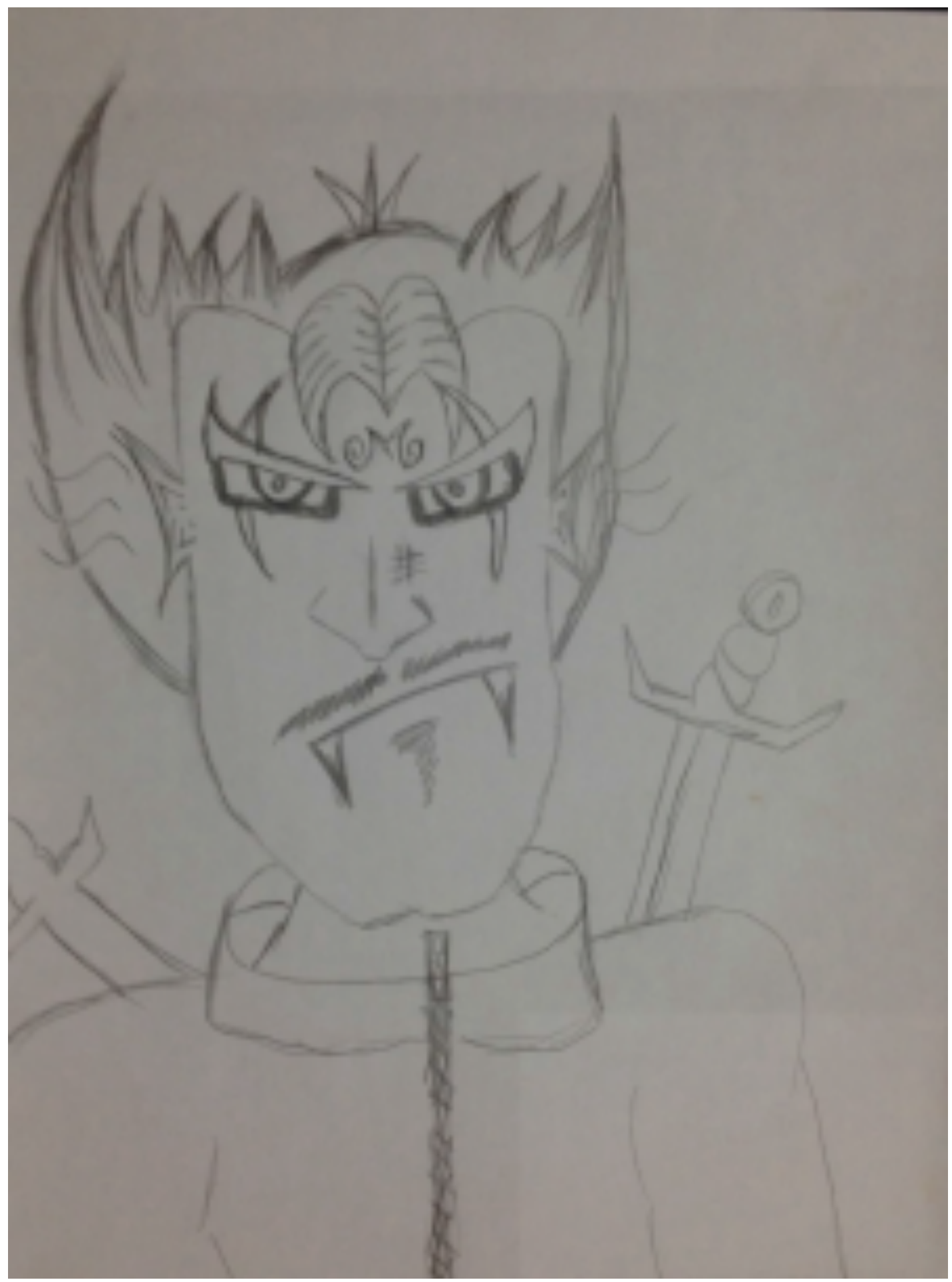

Figura 16 - Desenho 16 
Marcos disse que estava cansado e não quis comentar os desenhos de 16 a 19. Ele ilustrou uma figura masculina com duas espadas nas costas, dentes como os de vampiro, cabelo para cima como se fossem chifres e um olhar marcado, feito com traços fortes. Essa ilustração é próxima ao que ele fez no desenho 1, onde representou uma espécie de guerreiro, com a diferença de que no primeiro desenho a imagem estava sorrindo e nessa, ela se apresentou séria, com "cara de mau". Essa representação passa a impressão de que Marcos sempre precisa estar em alerta e pronto para se defender de alguma violência, o que confere com sua história, pois ele vivenciou diversas situações de violação de direitos e humilhações.

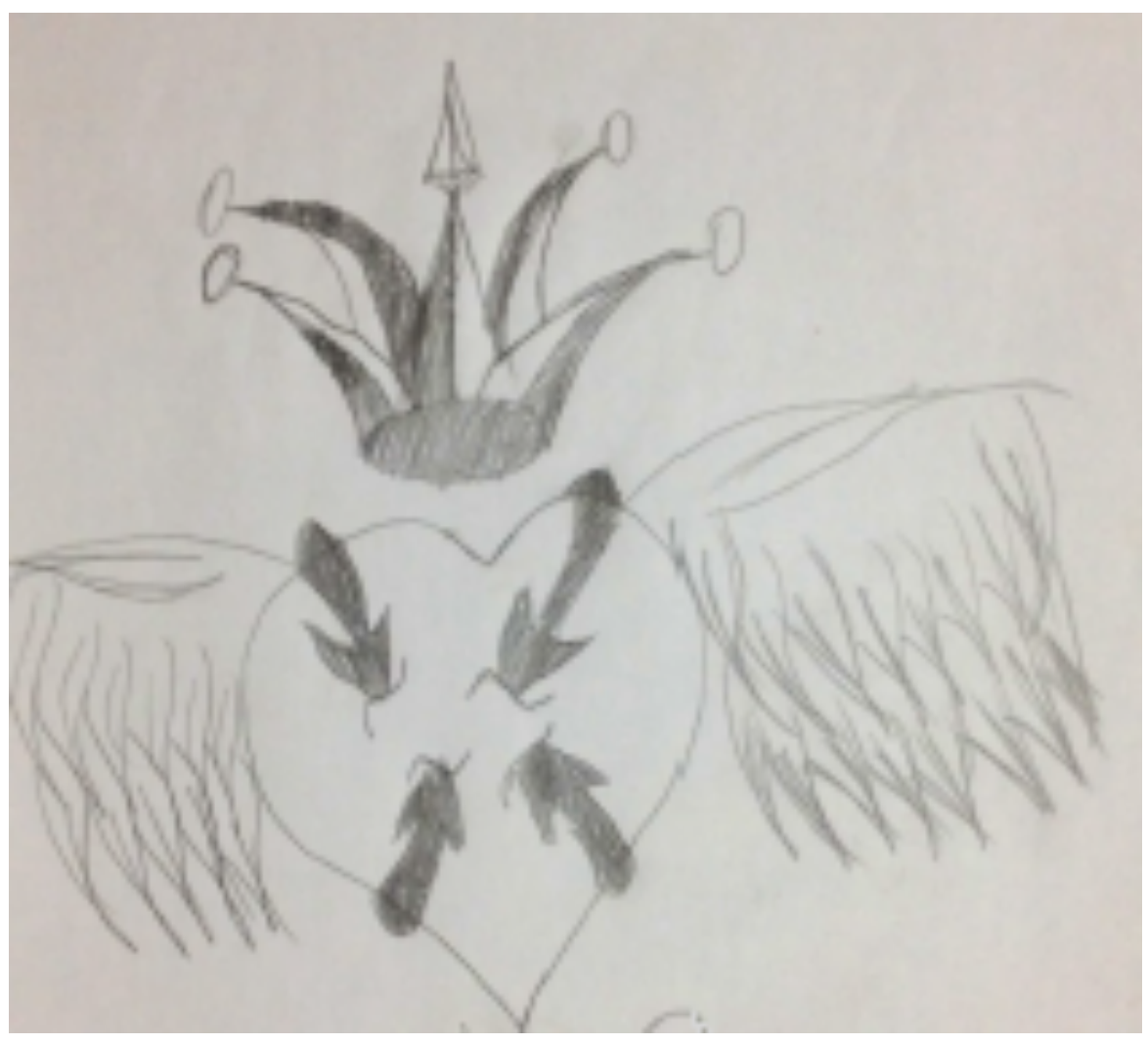

Figura 17 - Desenho 17

No desenho 17, Marcos fez um coração com asas e perfurado por setas, como também fez no desenho 1. A diferença é que nesse, sobre o coração, havia um chapéu como o de um bobo da corte, pessoa da época da monarquia responsável por entreter o rei e a rainha, fazendo-os rirem. Essa representação passa a ideia de que, apesar de um coração perfurado, 
da presença de um sofrimento, é preciso se "fazer de bobo" e, não só mostrar que está tudo bem, mas fazer os outros ficarem contentes com ele. Mas no final da página, Marcos escreveu "vida loka", expressão utilizada por aqueles que cometem atos que amedrontam as pessoas, como roubos, tráfico de drogas e não respeito às regras sociais de forma geral. Assim, tem-se uma representação que indica simultaneamente, ser visto como um bobo e ser visto como alguém envolvido em uma vida fora das normas sociais, indicando também, sofrimento em meio a esse dilema. No desenho 18, a figura do pica-pau aparece novamente, mas dessa vez sua aparência está menos agressiva que no desenho 5.

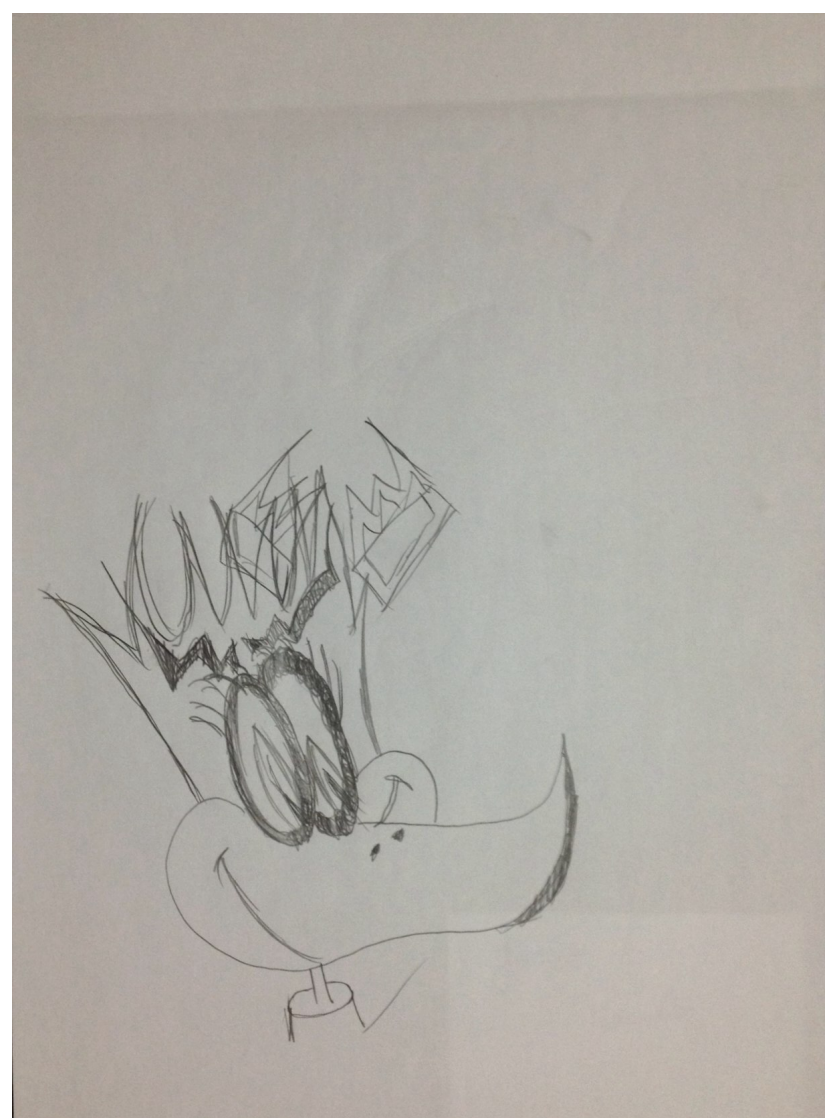

Figura 18 - Desenho 18 


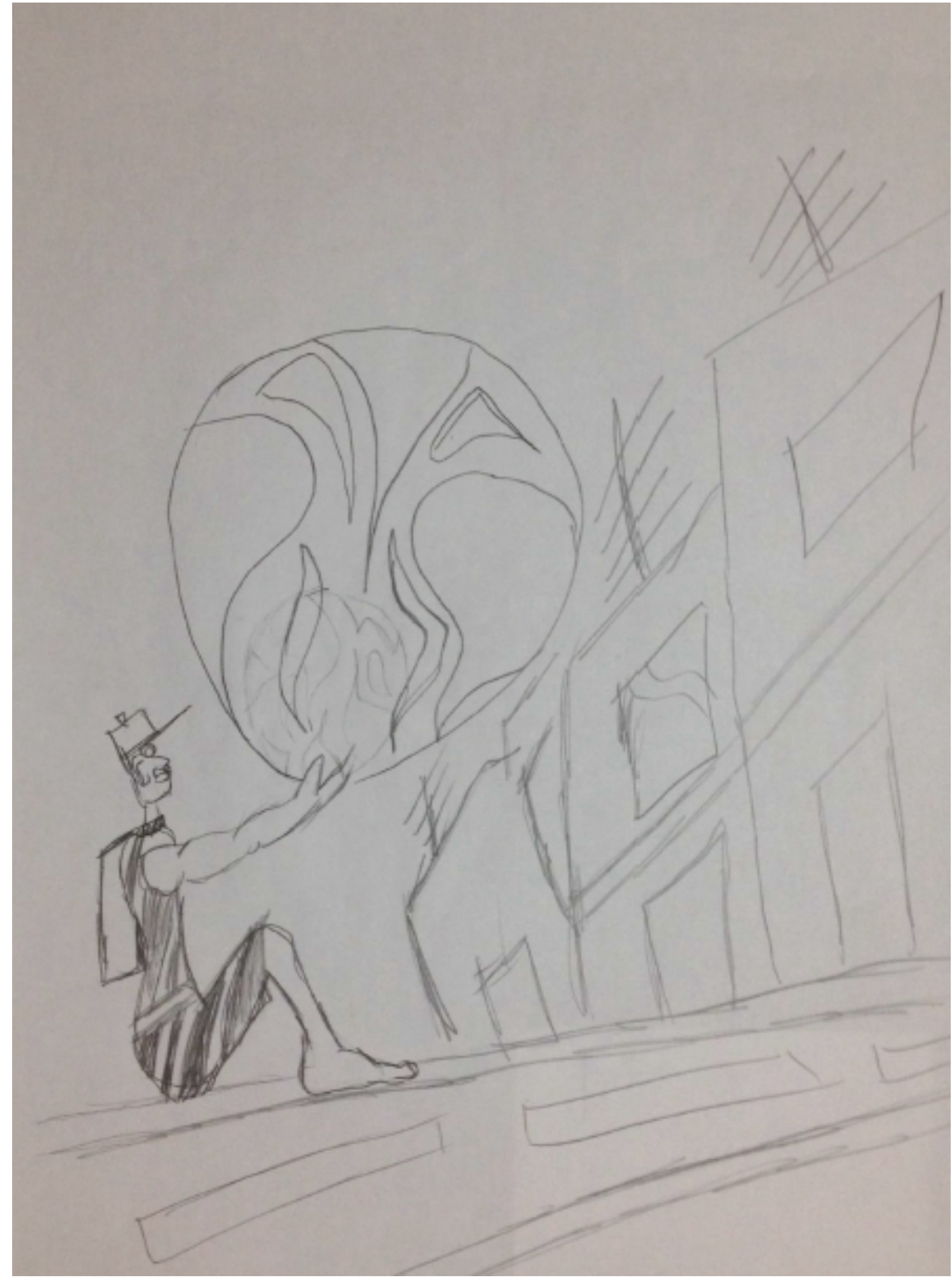

Figura 19 - Desenho 19

Já no desenho 19, Marcos ilustrou uns prédios e uma rua, com uma figura masculina sentada na beira da calçada e segurando uma espécie de bola. Nota-se que inicialmente, ele 
desenhou uma bola de tamanho bem inferior, quando apagou e desenhou outra, aproximadamente três vezes maior que a inicial. De acordo com desenhos posteriores, é possível fazer uma correlação entre a figura masculina e Marcos, pois ele se representa da mesma maneira em outra folha. E a bola, também de acordo com o último desenho que ele elabora, representa o mundo. Marcos não quis comentar esse desenho, mas passa a ideia de que, apesar de estar em desvantagem social pela sua história de constantes institucionalizações, pode manipular o mundo, apesar desse ser grande, e brincar com ele, aprendendo a fazer uso das situações nas quais se encontra, a seu favor. A partir dessa imagem, tem-se indícios de que Marcos não se vê mais como totalmente passivo diante do que vive, impotente para agir, mas sim como alguém que tem uma margem de manobra para influenciar os contextos nos quais está inserido.

\subsubsection{Desenhos 20, 21, 22 e 23}

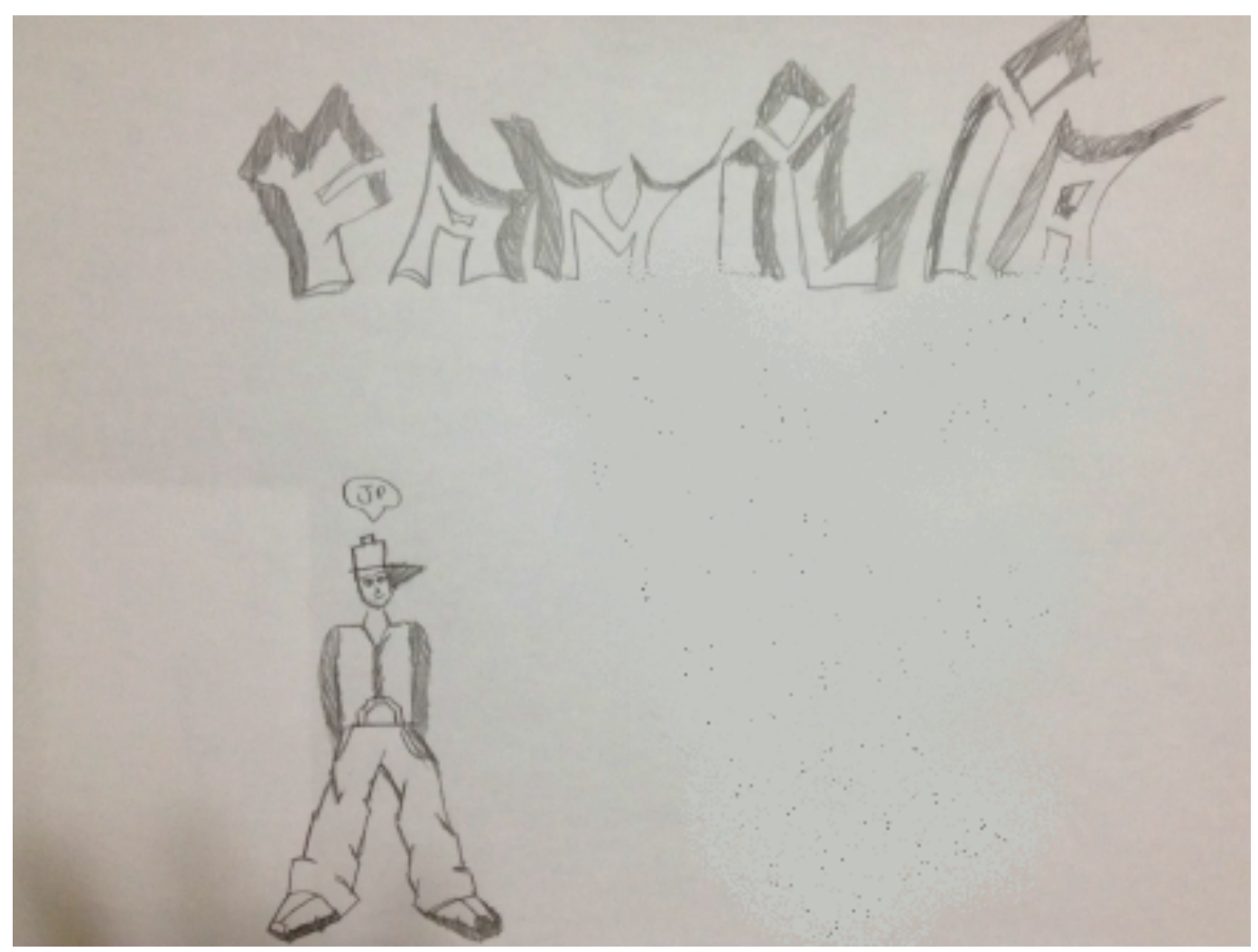

Figura 20 - Desenho 20 
Como rede de apoio daquele momento, Marcos a representou no desenho 20, segundo solicitação da pesquisadora, inserindo as pessoas com as quais podia "contar". Inseriu o nome das pessoas com quem morava e quem era dessa família: cinco mulheres, um rapaz que ele tinha como um irmão mais novo. Também escreveu o nome da coordenadora do Abrigo Institucional D, onde ele ficou um tempo, e que era coordenadora do Abrigo Institucional $\mathrm{E}$ quando foi acolhido lá, ambos acolhendo adolescentes e jovens em situação de rua. Outro nome foi o de um educador que também trabalhou nos Abrigos Institucionais D e E. Esses dois últimos foram os que o levaram para o Abrigo Institucional E, quando ele morou sozinho pela última vez e não estava conseguindo organizar sua vida sozinho: não organizava a casa, não buscava um emprego e estava usando muita droga junto às pessoas conhecidas da localidade. Essa coordenadora da instituição D “pegava no seu pé”, segundo Marcos, sempre falando para ele ficar longe das drogas, procurar um trabalho e voltar a estudar. Ele pensava que ela tinha algo contra ele, mas depois viu que, na verdade, antes ele era muito "solto na vida”, não tinha ninguém para chamar sua atenção e a coordenadora queria mostrar para ele que a vida tinha limites. Então, passou a entender que a postura dela era necessária para ele se organizar melhor.

Também colocou o nome do seu filho, da mãe do seu filho e da pesquisadora. Por cima de todos, em primeiro lugar, escreveu Deus. Enquanto estava no sistema penitenciário, Marcos frequentou os cultos evangélicos que ali ocorriam. Zilma e seu filho ficaram mais distantes dele, no desenho, provavelmente porque não os via com frequência. Como título do desenho escreveu "família". Assim, como rede de apoio, Marcos apresentou pessoas que estavam próximas naquele momento, que se resumiam à família com quem ele estava morando, a coordenadora e um educador social da Instituição D, com os quais ainda mantinha contato, a pesquisadora, seu filho e a mãe desse. Vale lembrar que Marcos estava morando na casa de uma ex-educadora social da Instituição D que, assim como a coordenadora e o 
educador da mesma instituição, faziam parte de um mesmo grupo social. A família biológica de Marcos não apareceu na relação, nem em qualquer outro grupo ou instituição.

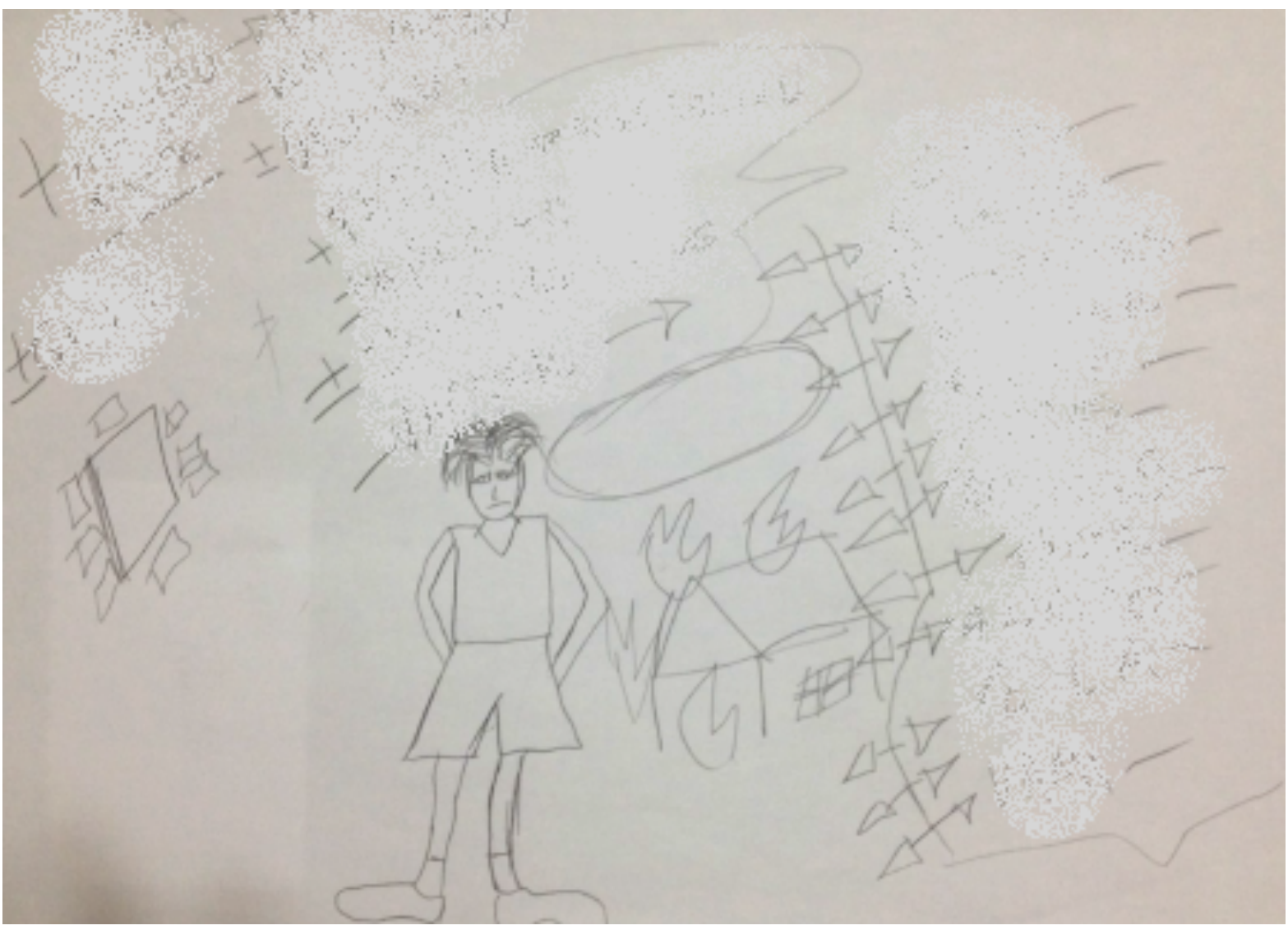

Figura 21 - Desenho 21

No desenho 21, Marcos representou as pessoas que marcaram sua vida, ao longo dos anos. Se desenhou mais novo e disse que tinha o cabelo ruim de negro e era "idiota demais". Quando se lembrava de como andava, sentia vergonha. Primeiro escreveu o nome da mãe social da Instituição B, a quem chamava de mãe. Depois, o nome do coordenador do primeiro abrigo onde foi acolhido (e que abusou sexualmente dele também). Perguntou para a pesquisadora se era somente quem tinha feito coisa boa ou quem também tinha feito coisa ruim. Ela disse para colocar os dois, todos os que marcaram sua vida. Então, ele inseriu o nome de um acolhido do primeiro abrigo também. 
Combinaram que ele colocaria um sinal de mais $(+)$ para os que o marcaram de forma positiva, ou um sinal de menos (-) para os que o marcaram de forma negativa. Os que marcaram sua vida das duas formas, receberiam os dois sinais. O coordenador do primeiro abrigo recebeu um + e um - porque ele bateu nele várias vezes mas, ao mesmo tempo, levava Marcos para vários passeios com uns estrangeiros que visitavam o abrigo. O menino que ele escreveu em seguida recebeu um - porque abusou sexualmente dele quando Marcos tinha 8 anos de idade e esse menino, 17. A mãe social recebeu um + porque foi ensinando as coisas para ele, devagar, já que Marcos chegou perdido na cidade, depois que saiu da primeira instituição que ficava numa área rural.

Maria Helena, sua namorada da Instituição B, recebeu um + e um - porque ela não podia engravidar e o sonho de Marcos era ter um filho bem jovem para ver seu filho grande junto dele e eles poderem passear. Também escreveu o nome da mãe do seu filho Pedro, dizendo que ela fazia parte do passado, indicando $-\mathrm{e}+$ para ela. Ainda em relação ao segundo abrigo, escreveu o nome de um menino acolhido, responsável pela primeira vez que cortou seu pulso, indicando - para ele. Toda vez que olhava para a cicatriz se lembrava do que havia acontecido.

Os nomes dos acolhidos Paulo, André e Fábio, que eram como irmãos para ele e que foram transferidos com Marcos da primeira para a segunda instituição, também foram registrados, com um sinal de +. Já a madrinha Sílvia, da Instituição B, foi marcada com + e -. Escreveu o nome da adolescente que o abusou pela primeira vez no primeiro abrigo, marcando -. Assim, de forma geral, Marcos construiu vínculos positivos e negativos nas duas primeiras instituições nas quais foi acolhido, chegando a classificar como vínculos positivos e, ao mesmo tempo, negativos, os formados por pessoas mais significativas, sendo elas o dirigente da Instituição A, a namorada da Instituição B e sua madrinha, também da Instituição B. 
Em relação à Instituição $\mathrm{C}$, todos os 10 nomes que escreveu foram marcados com o sinal de -, dizendo que alguns funcionários eram carrascos. Outros eram rápidos para achar droga que ele escondia ou para descobrir quando estava transando com alguma menina no quarto. Outros três batiam nos meninos do local. Uma assistente social foi marcada com sinal - porque ela, por mais que quisesse vê-lo bem, não sabia o que fazer, já que avaliava Marcos pelo conteúdo que estava nos relatórios das outras instituições. Uma psicóloga também foi marcada com sinal - porque, para ele, psicólogo até quer ajudar, mas do jeito que for mais fácil para ele. Assim, na terceira instituição onde ficou acolhido, não conseguiu identificar qualquer funcionário de forma positiva. Vale ressaltar que foi nessa instituição que Marcos começou a criar estratégias coletivas para se proteger, o que pode ter dificultado a criação de vínculos positivos com a equipe nesse local.

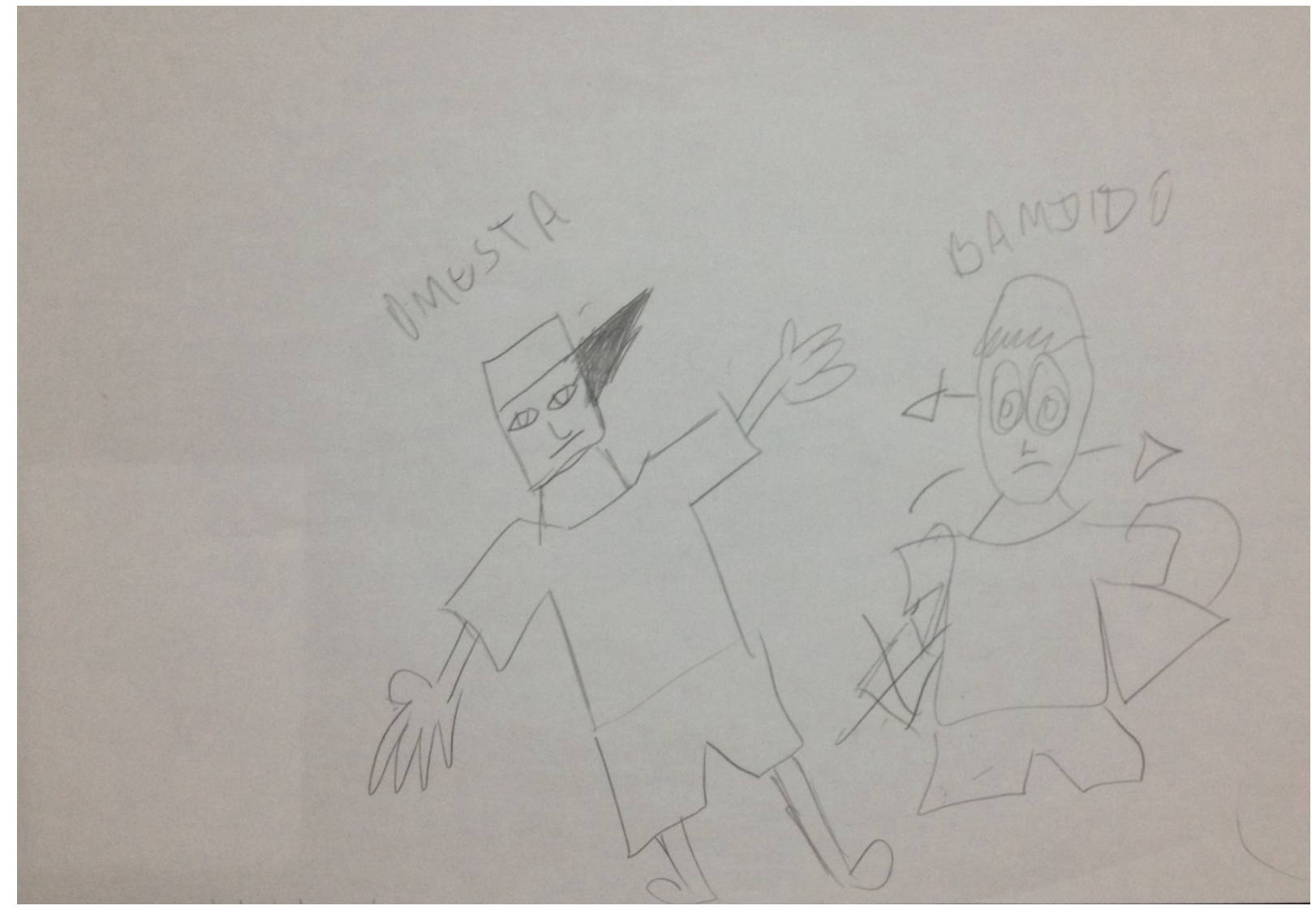

Figura 22 - Desenho 22 
Em relação ao desenho 22, Marcos representou, a pedido da pesquisadora, como ele se via na sociedade: uma pessoa que queria "se recuperar", que queria ficar tranquilo, ser uma pessoa "normal", um pai de família, sem que ninguém olhasse para ele e dissesse que ela era "vagabundo". Queria ser uma pessoa honesta.

Em relação a como as pessoas o viam, era como um "vagabundo". Em cima dessa segunda representação, Marcos escreveu "bandido". Quando alguém estava na rua com uma bolsa, ela a colocava do outro lado do corpo para passar perto dele, e isso o deixava revoltado. Ele não estava pensando em roubar ninguém, mas sempre achavam que ele iria roubar algo. E pensavam isso porque, segundo Marcos, ele era negro, como se todo negro precisasse roubar e usar droga, ou, então, acrescentou que pensavam que ele era um "vagabundo", somente porque ele estava usando chinelo. Pontuou que se um negro entra em um mercado, já pensam que ele vai roubar algo. Assim, quando ele entrava em um estabelecimento comercial, o segurança do local sempre o seguia para verificar se nada iria acontecer. Mas ele gostava de surpreender as pessoas, como quando comprou seu tênis de marca cara e algumas roupas. No início, não queriam atendê-lo na loja. Mas depois que falou que iria pagar em dinheiro, já que havia recebido a indenização pela morte de sua mãe, começaram a tratá-lo bem, até o chamaram pelo nome.

Nesse ponto, evidencia-se que, ao invés de Marcos falar como ele se vê, ele diz de como ele gostaria de ser visto pelo outro: uma pessoa honesta. Mas o olhar desse outro sempre o coloca na posição de um bandido, que merece, inclusive, ser seguido quando entra em qualquer tipo de loja, pois pensam que ele vai roubar algo. Essas duas imagens, ser honesto e ser bandido, aparecem de forma geral em toda a narrativa de Marcos em forma de dualidade, pois ele fica em um dilema entre continuar buscando o reconhecimento enquanto alguém honesto, enquadrado nas normas da sociedade, ou assumir o lugar no qual já o viam, o 
de bandido, lugar esse nada bem visto pelas pessoas de forma geral. Um ponto a ser ressaltado é que no próprio desenho, o rosto de Marcos honesto é quadrado, enquanto o rosto de Marcos bandido segue o formato normal de uma cabeça. Além do mais, quando Marcos indica que toda pessoa negra e de chinelo é mal vista pela sociedade, ele está indicando como esse grupo social está sendo visto pelas outras pessoas que são diferentes deles, marcadas negativamente pela sua aparência.

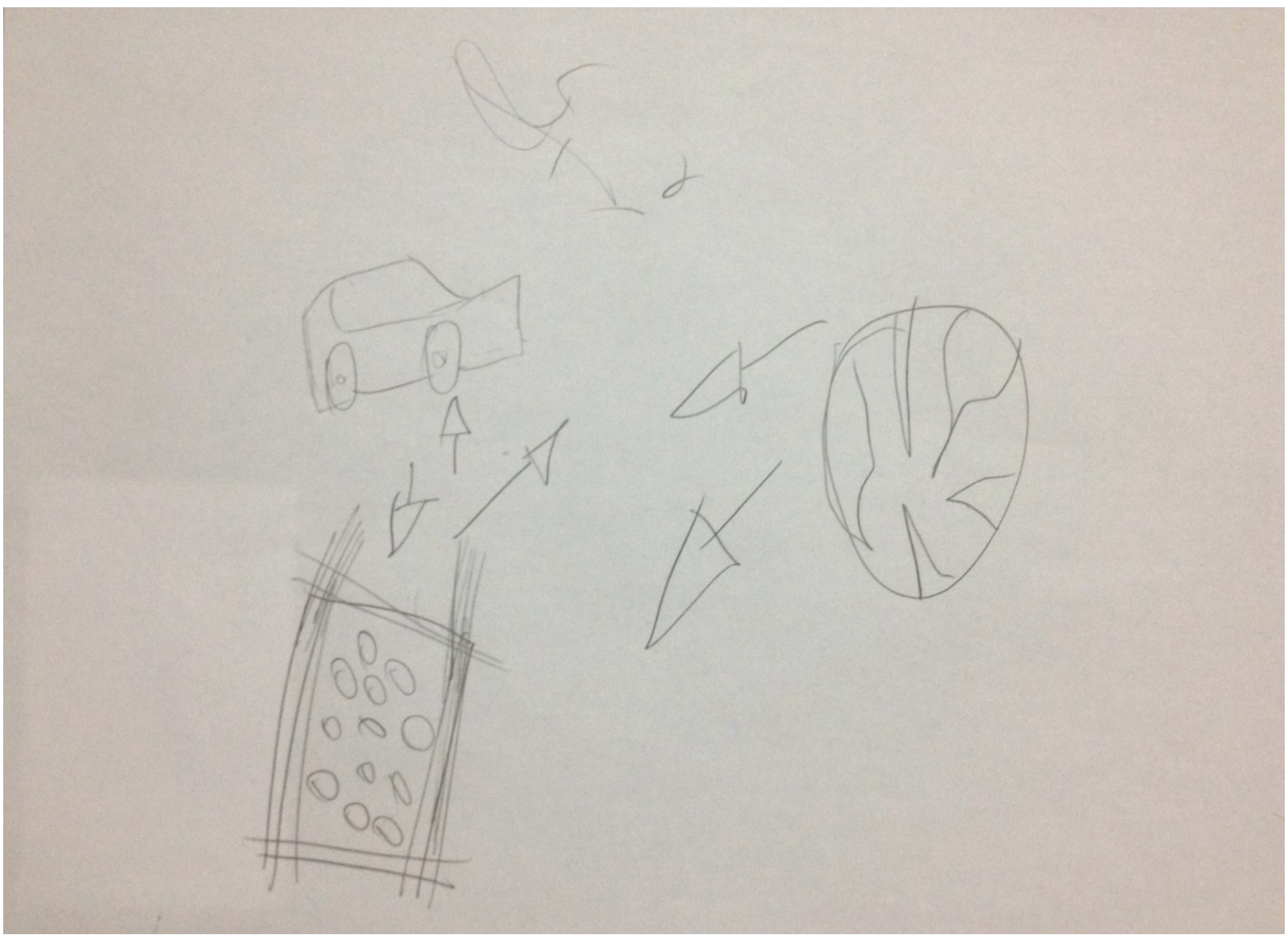

Figura 23 - Desenho 23

E por fim, o último desenho, de número 23, representou a posição de Marcos na sociedade, segundo pedido da pesquisadora. Primeiro ele desenhou seu mundo, que era pouco diferente do mundo dos outros (fez um mundo quadrado). Depois desenhou o mundo das outras pessoas, redondo, e explicou a diferença entre esses mundos. No mundo redondo, as 
pessoas eram materialistas, só gostavam de dinheiro e não queriam saber o que o outro sentia ou porque uma pessoa estava na situação em que se encontrava. Não queriam saber porque uma pessoa usava droga, se prostituía, dormia na rua, estava suja ou andava como um "trombadinha". Só sabiam julgar e dizer que essas pessoas eram "marginais". Mantinham distância de quem eles consideravam "bandido" e nunca ofereciam ajuda, comida ou um banho. Todos do mundo redondo se afastavam das pessoas do mundo quadrado porque essas pessoas "fediam".

No mundo quadrado, seu mundo, estavam as pessoas que já nasceram com vida destruída, com a família desorganizada. Por família desorganizada, se referia às famílias nas quais o pai alcoolista, batia na esposa e nos filhos. Essas famílias expulsavam as pessoas de casa. Foi o que aconteceu com ele. Seu pai era alcoolista e seu avô era ignorante. Se tivesse crescido no meio deles, achava que estaria pior. Não tinha o amor de suas tias e nem havia tido o de sua mãe, que era "prostituta" e não "arrumava as coisas para ele". Outro ponto a se destacar é a semelhança entre o mundo no qual Marcos fazia parte e a prisão, onde se fica em um "quadrado", ou seja, em uma cela. Talvez essa semelhança fizesse alusão à grande possibilidade de pessoas do mundo quadrado irem cumprir pena no sistema prisional, por terem cometido algum crime.

Por mais que uma pessoa do seu mundo comprasse um carro muito caro, e fosse para o mundo redondo, essa pessoa continuaria a "ter sentimentos", pois sempre iria se lembrar do sofrimento que viveu. Mesmo que uma pessoa saísse da favela, a favela nunca sairia dela. É uma marca que ficava. E sempre que essa pessoa, que foi para o mundo redondo por ter adquirido bens materiais caros, visse uma pessoa do mundo quadrado em situação difícil, iria ajudar.

Ainda segundo Marcos, no mundo redondo, as pessoas também sofriam, mas era diferente, pois elas não conseguiam ver o sofrimento dos outros que nasceram numa condição 
inferior, no mundo quadrado. Na verdade, elas não se importavam porque eram egoístas e só queriam saber da própria vida. E por mais que Marcos contasse sua história, as pessoas do mundo redondo nunca iriam querer saber quem ele era, o que já tinha passado, como estava naquele momento. Mas elas tinham que saber que a qualquer dia, um filho ou o próprio pai poderia estar do mesmo jeito que ele.

Então, para Marcos, existem dois mundos, compostos por pessoas diferentes: as que têm dinheiro e as que nascem com a vida "destruída", em famílias "desorganizadas". Essa visão da sociedade mostra a oposição entre dois grupos sociais que vivem separadamente. Os mais desfavorecidos contam com a solidariedade dos demais desse mesmo grupo, e, mesmo se um deles alcance benefícios e passe a integrar o grupo social dos mais favorecidos, esse não irá se esquecer de suas origens e saberá auxiliar alguém do seu grupo social de origem, caso haja necessidade. Por outro lado, os que compõem o grupo social mais favorecido, nunca vão querer compreender os sentimentos do grupo menos favorecido. Mas como Marcos indicou no desenho 19, onde segura o mundo redondo, ele consegue ter em suas mãos e manipular um grupo social que não se interessa por ele.

Transpondo essa questão para uma instituição que trabalhe com acolhimento de adolescentes, ocorre que os profissionais, que pertencem a um grupo social diferente do grupo dos acolhidos, muitas vezes não desejam compreender a história de vida dos adolescentes, que pertencem a outro grupo social, ou como indicou Marcos no desenho 21, pode até haver uma boa intenção em ajudar, como a assistente social da Instituição C que o acompanhava, mas ela não conseguia acessar o que ele sentia e seguia suas intervenções a partir do que estava registrado no prontuário. Pode-se indicar que, a partir da colocação de Marcos, a instituição de acolhimento reflete uma organização social que conta com dois grupos sociais distintos e que vivem suas rotinas de forma separadas, sem encontrar-se. Essa colocação vai 
ao encontro do que Gaulejac (2007c) pontuou, ao indicar que a relação que os profissionais da assistência social estabelecem com os usuários do serviço, são também relações de classe.

\subsubsection{Reflexões}

Em relação à produção de desenhos no momento em que o participante Marcos narra sua história de vida, pode-se indicar esse recurso como um importante instrumento de acesso a essas vivências. Para o adolescente, o uso da linguagem oral aliada a um mediador concreto pode significar a produção de algo que ele visualiza e, de certa forma, controla, podendo auxiliar na organização de suas ideias. Também, esse mediador concreto pode desviar o olhar do adolescente para algo que acompanhe suas emoções e seus sentimentos, quando ele pode fazer um traço mais forte quando estiver com raiva, amassar com força uma argila ao falar de uma situação humilhante ou facilitando a fala de situações constrangedoras ao rasgar figuras aleatórias de revistas. $\mathrm{O}$ elemento mediador precisa estar em sintonia com a afinidade do adolescente, seja desenho, massa de modelar, colagem ou outros. Ao expressar o que sente realizando algo concreto, esse sentimento, nem sempre nomeado pelo adolescente, pode encontrar uma via simbólica de expressão e facilitar o uso da linguagem oral na expressão de histórias de vida. E, dessa forma, não é necessário olhar para o profissional e ficar sujeito à sua aprovação ou desaprovação sobre o que é contado, que muitas vezes aparece por meio de um gesto ou de um olhar de surpresa diante do que está sendo dito.

Outro aspecto a ser ressaltado é a representação gráfica de diversos elementos, muitas vezes contraditórios, presentes na história de vida de Marcos. Mas para além do que é dito, o desenho complementa a trajetória narrada com outros aspectos, nem sempre ditos de forma direta. Vale salientar que a interpretação do que é produzido, seja um desenho, uma colagem ou outro, precisa ocorrer a partir do que é narrado e, se possível, considerando o que o adolescente tem a dizer sobre o que construiu. 
Além de desenhos livres, ao final da última entrevista da pesquisadora junto a Marcos, algumas produções foram direcionadas, sendo também importante meio de se conhecer algumas dimensões de uma história de vida, relacionando-a a um contexto social mais amplo. No caso em questão, foi conhecer a rede de apoio do participante, como ele se percebe e é percebido pelas outras pessoas, qual sua visão de mundo e como a dinâmica de nossa sociedade se organiza. Esses são pontos importantes para que se compreenda os rumos que a trajetória de Marcos foi tomando, incluindo escolhas de Marcos, sempre dentro de um contexto social mais amplo. Assim, o uso do desenho na intervenção junto a adolescentes acolhidos, de forma direcionada ou não, amplia as possibilidades de compreensão das histórias desses meninos e meninas, possibilita maior aproximação desses com a equipe e favorece a criação de alternativas de trabalho no contexto do acolhimento institucional de adolescentes. 


\section{ESTUDO 2 - SIMONE : A BUSCA DE PERTENCIMENTO}

\subsection{NÍVEL DESCRITIVO-CRONOLÓGICO}

O acesso à história de vida de Simone ocorreu por meio de quatro encontros, nos quais foram realizadas entrevistas abertas, em que ela poderia falar de suas vivências livremente. Os encontros ocorreram na Unidade de Acolhimento onde Simone se encontrava acolhida, em seu quarto, conforme escolha da participante. Após a primeira entrevista, Simone pediu para que eu levasse algum lanche para ela, indicando que gostaria de receber concretamente, uma contrapartida em relação à sua participação na pesquisa. Foi o que ocorreu, mas os itens desse lanche foram organizados para que todos os demais acolhidos daquele local pudessem se beneficiar.

O primeiro encontro com Simone ocorreu com a pesquisadora deste estudo e com uma mestranda, do mesmo grupo de pesquisa sobre acolhimento institucional que estava em andamento. Vale ressaltar que as duas pesquisadoras haviam conhecido Simone quando trabalharam na coordenação de uma instituição de acolhimento, onde ela estava acolhida à época. Esse conhecimento prévio e a existência de um bom relacionamento com a participante, levaram Simone a ser convidada a participar tanto desta pesquisa, quanto da investigação da mestranda. Nesse primeiro momento, a mestranda aplicou um questionário semiestruturado, buscando informações sobre a família de Simone, sobre sua situação de acolhimento e da rede socioassistencial que havia sido acionada pelos profissionais da instituição, durante seu acompanhamento. Dos quatro encontros seguintes, em que Simone apresentou sua história de vida, em apenas um, a mestranda compareceu. Uma observação de Simone diz respeito à comparação entre as duas formas de coleta das informações: entrevista semiestruturada e espaço livre para que pudesse apresentar sua trajetória de vida. Ela afirmou 
que a presença de um questionário ajuda, pois não é necessário pensar muito para se expressar.

Assim como ocorreu com Marcos, o critério para o térmico das entrevistas foi o da participante ter apresentado à pesquisadora sua trajetória de vida desde quando era criança até aquele momento. Foi sendo percebido, tanto pelo participante quando pela pesquisadora, que ela já havia expressado muitas experiências de todas as suas fases de vida.

\subsubsection{Infância - antes do acolhimento institucional}

Simone é uma menina que morou com seus pais e seus irmãos no mesmo local até os 8 anos de idade. Ela possuía uma marca de queimadura no rosto, mas seus pais nunca disseram como essa marca surgiu. Ela imaginava que seu pai a queimara depois de muito brigar com sua mãe, já que para ele, ela não era filha dele. Mas ela não gosta de ficar tentando saber o que causou a queimadura no seu rosto, pois sentia raiva do seu pai, da sua mãe e de todo mundo. A raiva pela mãe era pelo fato de que ela não falava o que havia acontecido, apesar de Simone nunca ter perguntado a ela. Para Simone, ela já nasceu com essa marca. Na época dos encontros com a pesquisadora, ela estava com uma cirurgia marcada para amenizar o sinal no rosto e imaginava que iria ficar bonito. Muitas pessoas ficam perguntando o que aconteceu para ela ter o rosto daquele jeito, mas ela sempre dizia que não sabia. Ela não gostava de tocar no assunto, então interrompia quem está falando com ela, sendo que nesse momento a chamavam de ignorante. Simone disse que, na verdade, ignorante é a pessoa que faz esse tipo de pergunta.

Um acontecimento marcante da infância de Simone foi a morte de sua mãe quando ela tinha em torno de 8 anos de idade. Antes, moravam ela, seus pais e seus irmãos e todos viviam momentos mais tranquilos, pois, em todo final de semana, a família organizava as refeições em conjunto e faziam churrasco. Havia muita comida e bebida nessa época, tinham 
muita fartura. Todos ingeriam bastante bebida alcóolica durante os churrascos, inclusive Simone, que ainda era criança.

Sobre a mãe de Simone, lembra-se dela com o cabelo de vários tamanhos, loiros e com uma tatuagem no tornozelo. Não sabe ao certo qual era a tatuagem, mas relata que ela iria tatuar também as letras dos nomes dos filhos, o que não se concretizou pelo seu falecimento. Simone se lembra do dia em que sua mãe faleceu. Estavam todos reunidos na sala, seu pai bebendo alguma bebida alcóolica em um bar das redondezas quando sua mãe, que estava grávida, começou a sentir muitas dores no ventre, o que indicava que o bebê iria nascer. Sua mãe então, chamou algum homem que estava próximo, para ajudá-la, pedindo em seguida para os filhos maiores cuidarem dos menores. Eram sete filhos no total. Sua mãe entrou em um carro com um vestido preto e não voltou mais. Essa era a última cena que Simone se lembra de sua mãe. Simone e seus irmãos ficaram na chácara onde moravam, por uns dias, sem ter notícia da genitora. Essa saiu em uma quarta-feira para o parto do filho, mas morreu no dia seguinte, no hospital. Simone e seus irmãos só ficaram sabendo de sua morte no sábado, ou seja, três dias após o óbito, porque um tio escondeu o acontecimento dela e de seus irmãos.

Sua mãe morreu no mês de abril e no final do mesmo mês, seu pai recebeu uma nova companheira em casa, que tinha uma orientação religiosa protestante. Ela tinha três filhos, porém, somente uma filha foi morar com eles. Simone mantinha contato com os demais filhos, mas eles não gostavam dela e nem de seu pai. Somente a filha da madrasta que morava com eles, que também era de orientação religiosa protestante, gostava de Simone. Então, Simone, criança nessa época, maltratava o filho adolescente da companheira do pai.

O pai de Simone gostava de uma das filhas de sua companheira, uma mulher solteira, que engravidou. Simone não tinha certeza se o filho era mesmo dele mas, depois que o menino nasceu, o pai de Simone começou a tratar o bebê melhor que a ela e seus irmãos. Para ela, a 
companheira de seu pai da época, mãe da mulher que ele engravidou, não ficava com ciúmes, já que seu maior interesse era o dinheiro que ele possuía. O pai de Simone não registrou o menino em seu nome porque a mãe da criança tinha namorado na época. Quando o namoro do seu pai terminou, Simone foi morar com a ex-madrasta, a convite dela. A decisão de sair da casa do pai ocorreu pois, como ela afirmou, seu pai não gostava dela. Então, foram para uma casa nas proximidades, numa espécie de favela.

Com 10 anos, Simone foi morar com um traficante de drogas da região e com outras meninas também, quando usou maconha pela primeira vez. Não gostou muito dessa primeira vez, já que ficou com muito sono e muita fome, ao mesmo tempo que ria bastante. Mas depois, passou a usar com frequência até os 11 anos de idade, quando voltou para a casa do pai. Relatou que, durante o período em que ficou fora de casa, morando com o traficante, foi prazeroso. Conheceu coisas que não conhecia, como drogas, e teve relacionamentos com homens mais velhos, mas disse que esses relacionamentos não davam muito certo.

Depois que voltou para a casa do pai, Simone passava o dia fora e somente voltava à noite, sob efeito de drogas, para dormir. Disse que na casa não havia luz, água, comida, "não tinha nada". Ao acordar, voltava à favela, onde havia morado com o traficante, e passava o dia. Aos 12 anos, foi morar com uma tia porque seu pai queria matá-la. Após um tempo, foi morar com sua irmã. Essa irmã havia se casado aos 14 anos para sair de casa e engravidado com 18 anos. Enquanto estava morando na casa da irmã, Simone ficava fumando maconha dentro do único quarto da casa, com seu cunhado e a própria irmã. Um dia, após fumarem, comerem e sujarem o quarto, o sogro da irmã chegou e brigou com eles. Como ele era de uma religião protestante e os vizinhos comentavam com ele sobre o cheiro da maconha que vinha de sua casa, ele ficou furioso.

Nessa época, os irmãos gêmeos de Simone também foram morar com a irmã porque a tia deles pensava que a irmã de Simone era responsável por cuidar deles, mas no local não havia 
condições para todos morarem juntos. Eles não ajudavam nos afazeres domésticos e Simone chegou a um ponto de não querer mais tomar banho. O que deixava Simone chateada era o fato de o sogro da irmã pertencer a uma religião protestante e não deixá-la namorar.

A irmã de Simone era espancada pelo marido, mas Simone não deixava que isso acontecesse na sua frente, dizendo que se ele batesse na irmã, Simone iria matá-lo. Um dia, o marido da irmã pegou um chinelo e Simone pegou uma faca, ameaçando-o caso machucasse sua irmã novamente. Ele ingeria muita bebida alcoólica e fumava muita maconha. Simone só gostava dele quando ele fumava maconha com ela. Ela vendia droga para ele, pois na localidade onde moravam, todo mundo conseguia droga fácil.

Um dia, o sogro da irmã pediu para Simone e seus irmãos limparem o quintal todo. Eles limparam tudo, quando pessoas que trabalhavam no Conselho Tutelar chegaram de carro. Os funcionários do Conselho falaram para Simone e seus irmãos que iam levá-los para jogar futebol. Simone adorava jogar futebol, mas não queria ir naquele momento, pois queria fumar maconha. Por fim, a equipe do Conselho Tutelar levou os três para a sede do Conselho e ficaram oferecendo comida para eles o tempo todo, o que deixou Simone indignada, como se eles tivessem passando fome. Foram a irmã de Simone e o sogro dela que haviam chamado o Conselho Tutelar para levá-los a uma instituição de acolhimento.

Simone insistia no fato de que não queria ir para lugar algum, quando a conselheira começou a falar que iam ficar na instituição somente por dois meses e que no local havia muitas crianças e adolescentes que também estavam acolhidos. Simone disse que ninguém falou que também era um local onde havia drogas. Se tivessem falado, Simone pontua, teria ido mais rápido. Mas Simone, ao saber que iria para uma instituição, começou a chorar. A conselheira disse que o local ficava num espaço com mais de uma casa, e que talvez ela fosse ficar separada dos irmãos, cada um em uma casa. Assim, saíram do Conselho Tutelar às $15 \mathrm{~h}$ e 
chegaram na instituição de acolhimento às $18 \mathrm{~h}$, pois o local era longe. A ida para a casa da tia, depois para a casa da irmã e por fim, para o abrigo, ocorreu no mesmo ano.

\subsubsection{Adolescência - Acolhimento Institucional}

\subsubsection{Instituição A}

Simone foi encaminhada para um abrigo institucional onde havia quatro casas num grande terreno, além de local para trabalhos em grupo junto aos acolhidos e espaço para os profissionais. Ao chegar, Simone estava com uma fome "de mendigo", e pontuou que estava melhor vestida que as crianças e adolescentes que ali estavam. $\mathrm{Na}$ entrada da instituição, visualizou alguns acolhidos fumando. Ela disse que não queria ficar na instituição, mas não teve escolha. Outros acolhidos a chamavam de novata e um garoto, Marcelo, disse que ela era "folgada". Na mesma hora, Simone disse de onde estava vindo, um local da cidade conhecido por haver muitas gangues ligadas ao tráfico de drogas e ao crime ou ato infracional de forma geral, pontuando que, se "mexessem" com ela, eles "iam ver". Imediatamente Marcelo ficou quieto. Depois, ele quis "ficar" com ela, mas Simone não aceitou. O sentido de ficar é o de namorar, mas sem compromisso, como se fosse um namoro que durasse um momento só. Marcelo também quis bater nos irmãos de Simone, mas ela o impediu.

A Instituição A era composta por mais de uma casa, e Simone e seus irmãos foram encaminhados para a mesma casa. Assim que chegou nessa Instituição, Simone conheceu os demais acolhidos e passou a fazer uso de drogas com eles, o que facilitou sua convivência com os demais acolhidos. Ela pontuou que passou a usar mais drogas do que antes de ser acolhida. Dessa convivência na Instituição, ela aprendeu a ter um bom relacionamento com as pessoas e a ter paciência, o que não ocorria quando estava com sua família. 
Simone gostava quando havia festas e ganhava presente, mas não gostava quando era levada para a Delegacia da Criança e do Adolescente - DCA, quando se envolvia com brigas na Instituição A. Essa delegacia é responsável por receber denúncias e investigar casos de adolescentes que cometem atos infracionais. Festas com presentes e idas a delegacia foram as situações mais marcantes do período em que Simone esteve acolhida nesse local.

Em uma das vezes em que foi para a DCA, foi encaminhada para o Instituto Médico Legal - IML, da Polícia Civil, local onde se faz exames para identificar lesões corporais decorrentes de brigas ou qualquer outra infração ou crime. Enquanto aguardava atendimento, viu chegar uma mulher de outra nacionalidade que estava presa por transportar meio quilo de cocaína para o Brasil. Simone pontuou que já havia pensado em ser policial federal antes dessa experiência, que reforçou seu desejo. Ela presenciou a mulher estrangeira brigando com os policiais, falando com sotaque, e eles dizendo para ela ficar quieta, pois não estava em seu país. Simone gostaria de estar no lugar dos policiais, brigando com a referida mulher, mas iria liberá-la. Ela somente não deixaria passar se a pessoa estivesse portando pedra de crack, mas se estivesse com qualquer outro tipo de droga, deixaria a pessoa passar.

Duas profissionais foram importantes para Simone na Instituição A: uma assistente social que trabalhava como assessora da coordenação e a pesquisadora dessa pesquisa, quem fez a entrevista e que havia trabalhado como coordenadora do local. Simone disse também que antes dos atuais cuidadores sociais, que trabalham em regime de plantão $12 \mathrm{~h} \mathrm{X} 36 \mathrm{~h}$, era mais interessante. Nessa escala de trabalho, os cuidadores trabalhavam 12 horas corridas dia sim e dia não, já que tinham 36 horas de folga entre cada período de 12 horas de trabalho. Antes existiam mães sociais que cuidavam dos acolhidos, sendo que essas ficavam seis dias da semana, ininterruptos, na casa com eles.

Simone começou a ir e a permanecer na rua por influência de outros colegas da instituição de acolhimento. Lá eles tinham acesso a grande quantidade de droga. Quando ela 
ia para a rua, ficava próxima à Instituição A, com outros meninos que já estavam em situação de rua. Simone já havia praticado roubo a pedestres e depois conseguia comprar mais drogas com o que arrecadava do roubo. Ela também já havia vigiado carro em estacionamento em troca de dinheiro e pedido dinheiro e comida a pedestres, mesmo sabendo que a instituição de acolhimento fornecia alimentação.

Durante a primeira vez em que dormiu na rua, Simone sentiu muito frio e fome e teve que pedir esmola para comer. Ela estava com uns meninos e meninas que estavam em situação de rua e já tinham cometido homicídio, além de usarem drogas. Essa primeira saída para a rua ocorreu após um ano do acolhimento de Simone na Instituição A, quando ela fícou seis meses seguidos nessa situação. Esse foi o tempo máximo em que ficou na rua sem interrupção. Nesse período, Simone ficou um tempo em uma espécie de favela, que ficava ao lado da Instituição A, na casa da mãe de um menino. No local havia muita briga entre os moradores dessa comunidade. Simone usava droga dentro da casa onde estava, com os colegas, quando um dia, os donos da casa a mandaram sair. Assim, Simone saiu e foi ficando na rua.

Depois dos primeiros seis meses fora da Instituição A, Simone voltou para a Unidade de Acolhimento, mas retornou para a rua, onde ficou por mais dois meses, indo para a instituição novamente depois desse tempo. Ficava indo e voltando, entre a Instituição A e a rua. Simone roubava cobertor e colchão da Unidade de Acolhimento para usar na rua. Conseguia esses itens porque os acolhidos passavam para ela pela cerca. Eles também a entregavam marmitas que entregavam nas casas, para ela se alimentar.

Depois, mudaram as regras da Instituição A: caso os acolhidos saíssem e não voltassem em até 24 horas, eles precisavam ir a um Conselho Tutelar e solicitar um encaminhamento da equipe por escrito para entrar novamente na instituição. Muitas vezes, Simone não comparecia ao Conselho porque era longe e era necessário ficar esperando muito 
tempo para ser atendida. Assim, ia ficando na rua e pensava: "já estou aqui mesmo". Mas, se pudesse voltar para o acolhimento institucional de uma maneira mais simples, teria voltado com mais frequência.

Em uma das vezes que foi para a rua, Simone ficou três meses seguidos. Nesse período alguns meninos avisaram para a equipe da Instituição A onde ela estava e a psicóloga que a acompanhava, Noemia, foi até a rua conversar com ela. De tanto a psicóloga insistir, a adolescente voltou para o acolhimento. Simone disse estava com raiva de Noemia porque, antes de ir para a rua, havia solicitado um tempo para falar com ela, mas a psicóloga sempre ficava "enrolando". Então, na rua, aproveitou o momento e finalmente conseguiu conversar com Noemia.

Sobre a escola, quando estava com 14 anos, conseguiu ser aprovada ao final do ano letivo, mas nos outros anos não frequentou mais a escola. Enquanto estava acolhida na Instituição A, um tio seu aceitou acolher seus dois irmãos gêmeos, José e Joaquim, em sua casa, para morar com ele. Eles foram e Simone continuou na instituição.

Após o acolhimento institucional de Simone, ela voltou algumas vezes para o local onde morava, para visitar as amigas. Em uma dessas visitas, ficou sabendo que uma irmã havia se casado com um homem que morava nesse local. A cunhada da irmã também havia se casado. Sempre voltava nessa comunidade porque era um lugar que promovia festas com frequência, o que Simone gostava.

No Natal de 2010, quando estava com 14 anos, foi para a casa do tio, onde estavam seus irmãos José e Joaquim, mas seu tio brigou muito com ela por Simone haver usado maconha. Foi uma grande briga e Simone nunca mais voltou para essa casa. 


\subsubsection{Instituição A1}

Depois da Instituição A, Simone foi encaminhada para uma Casa Lar, uma residência que recebia até 10 acolhidos por vez. Essa Casa estava sob a mesma administração da Instituição A, sendo então, aqui denominada Instituição A1. No local, ocorreu o último episódio em que Simone dormiu na rua, mais exatamente numa praça perto da Casa. Decidiu assim fazer porque, segundo ela, a psicóloga Noemia não autorizou Simone a ir a uma festa. E para Simone, a não autorização ocorreu porque a psicóloga não confiava nela e em outros acolhidos da casa, pois Noemia acreditava que eles iriam usar drogas. Dias antes da festa, Simone tentou combinar com a psicóloga que ela iria dormir na casa de uma amiga e a psicóloga ficou de conversar com essa amiga, o que não ocorreu. Então, Simone foi para a festa mesmo assim e quando retornou à Instituição A2, a psicóloga não autorizou sua entrada, afirmando que era para ela ficar na rua. Então, Simone ficou uns tempos na rua.

Um dia, houve uma briga entre os acolhidos envolvendo Simone, e ela foi transferida para outra Casa Lar, aqui denominada Instituição A2, que também estava sob a mesma administração da Instituição A.

\subsubsection{Instituição A2}

Num final de semana, os acolhidos da Instituição A2 foram ao clube com os funcionários do local e voltaram com gripe. Artur, uma criança da Unidade que estava com 1 ano e 10 meses, ficou internado por três dias e Simone foi medicada, sendo liberada do hospital em seguida. No clube, Simone, inicialmente ficou com vergonha de entrar na piscina porque não podia entrar com roupa. Mas com o incentivo de outras duas colegas da casa, Jaqueline e Katia, conseguiu entrar de biquíni e se divertir. A psicóloga Noemia fez churrasco 
para eles no clube. Simone disse que foi um milagre esse passeio acontecer, pois não era costume eles saírem para se divertir.

Em outro episódio, Simone havia sido encaminhada para a Delegacia da Criança e do Adolescente - DCA. Isso aconteceu porque Simone saiu da casa com outros adolescentes, Ricardo e Elton, para fumar maconha e nesse meio tempo, um cuidador social, profissional que trabalha na casa e era responsável por acompanhar os acolhidos nas atividades cotidianas, encontrou um pouco de maconha na mochila do Ricardo, mochila que estava no quarto do adolescente. Quando Simone e seus colegas retornaram, esse cuidador não deixou eles entrarem na casa, mesmo eles pedindo, e, então, a saída que encontraram foi arrombar o portão da casa. Nessa hora, esse cuidador chamou a Polícia Militar e entregou a maconha aos policiais.

Os adolescentes foram conduzidos à DCA, foi registrado boletim de ocorrência e os três dormiram em outra Casa da Instituição A, já que a delegacia estava muito cheia e não havia espaço para eles ficarem. Voltaram para a Instituição A2 no dia seguinte, mas o profissional que fez a denúncia, ficou com raiva dos adolescentes.

Sobre o uso da maconha, Simone e seus colegas usavam em qualquer lugar perto da casa, mas para ela, a droga não fazia o mesmo efeito de quando começou a usar, com 10 anos de idade. Para obter maconha, Simone pedia dinheiro na rua, roubava ou traficava drogas. O valor da droga variava entre $\mathrm{R} \$ 5,00, \mathrm{R} \$ 10,00$ ou $\mathrm{R} \$ 20,00$.

Simone perdeu o hábito de estudar. Quando ainda ia para escola, dentro da sala de aula ficava com muita vontade de sair, já que alguns professores eram "folgados", como ela dizia. Ela nunca dizia que morava numa Instituição de Acolhimento, mas ficava com muita vergonha quando o carro da Unidade chegava para buscá-la em frente à escola. Para disfarçar, ela dizia aos colegas da escola que era alguém que resolveu dar carona a ela. Ela até tinha vontade de voltar a estudar, mas ficava com preguiça. Primeiro, porque sempre chegava 
atrasada, e isso ocorria porque as aulas começam às 7 horas da manhã e o carro da Instituição passava para pegá-la às 8 horas. Segundo, Simone dizia que assim que chegava na sala de aula, já existia um colega que a convidava para sair e fumar um cigarro, e ela o acompanhava. Deixava os cadernos em sua mesa e, ao final do horário das aulas, buscava seu material escolar para retornar à Unidade de Acolhimento.

Quando a professora questionava Simone sobre suas ausências, ela justificava dizendo que estava com dor de cabeça e não conseguia estudar. Um dia, a professora disse: "já sei, você não estava dentro da sala porque estava com dor de cabeça de novo", num tom de ironia, como se tivesse desconfiando que Simone, na verdade, não tivesse tanta dor de cabeça. Depois que chegou à Instituição A2, Simone frequentou a escola algumas vezes. Conheceu algumas pessoas, inicialmente "patricinhas" e "playboys", mas depois se inseriu em um grupo de "maloqueiros" da escola, no qual se sentia melhor.

Para visitar sua irmã, a Kombi da Instituição a levava, o que a deixava com muita vergonha. Ao deixá-la, os funcionários do Acolhimento pediam para sua irmã assinar uns papéis e as pessoas que estavam ao redor ficavam perguntando o que era aquilo. Simone tentava desconversar, dizendo que achava que queriam vender alguma coisa. Mas ela sabia que esses papéis eram relativos ao Termo de Responsabilidade que a irmã assinava quando recebia Simone.

Uma vez, quando os funcionários levaram Simone para a casa da irmã, ela saiu do carro e entrou imediatamente na casa, assim que o carro parou. Os profissionais que a levaram ficavam chamando Simone pelo nome e ela, dentro de casa, estava com vergonha de sair. Um funcionário deu o Termo de Responsabilidade para a irmã assinar e, todos os da vizinhança que estavam ali, perguntaram o que era aquilo. Simone disse que deviam querer vender cobertores e alguns acreditaram. Quando estavam de saída, a equipe da Instituição de Acolhimento gritou da rua, chamando por Simone e dizendo que na segunda-feira voltariam 
para buscá-la. Nessa hora, ela disse aos que estavam com ela que aquelas pessoas estavam “doidas", que só podiam estar brincando. Ela não queria admitir aos vizinhos que estava em uma instituição e que eles eram funcionários da Unidade de Acolhimento.

Depois de um tempo indo visitar a irmã, todos já sabiam que ela estava em uma Instituição e ele não conseguia mais esconder dos vizinhos essa informação. Eles achavam que isso era uma vantagem, mas Simone sentia vergonha por estar em uma Unidade de Acolhimento, pois ficavam perguntando para ela como estavam os "bandidos" que ficavam acolhidos com ela. Uma vez, uma vizinha disse que ela pertencia a uma instituição onde adolescentes cumprem medida socioeducativa de internação por terem cometido ato infracional. Simone xingou essa mulher, mas depois ficou sabendo que essa mulher ajudava sua irmã e se arrependeu de haver brigado com ela. Essa mesma vizinha, depois de um tempo, ficou com medo de Simone, pois a viu fumando maconha na rua.

Nessas visitas à irmã, assim que chegava ao local, algumas pessoas a convidavam para ir a um lugar perto dali. A irmã de Simone pedia para ela ficar em casa, mas Simone ia mesmo assim. À noite, a irmã de Simone também ia para o tal lugar e levava o filho. Simone contou que nesse lugar ficavam outras crianças também, além de que ela tinha acesso a vários tipos de drogas.

Noemia, psicóloga da Instituição de Acolhimento e responsável por fazer o acompanhamento de Simone, sabia que ela continuava usando drogas e disse que gostaria de transferi-la para outra Casa novamente. Noemia falou que Simone teve muitas oportunidades, mas não as soube aproveitar. Como exemplo, disse a Simone que ela já tinha alcançado uma vantagem por ter sido transferida para a Instituição A1, melhor que a Instituição A, já que a Casa era menor e oferecia melhores condições aos acolhidos. Porém, ainda segundo Noemia, como Simone havia conhecido outros adolescentes da região e passava muito tempo com eles, foi melhor ela sair daquele local. Na visão de Simone, seus amigos eram vistos como "má 
influência" pelos profissionais, por isso a mudaram de casa. Na Instituição A2, Simone também já havia conhecido outras pessoas da vizinhança, levando Noemia a pensar que o melhor era Simone se mudar novamente.

Enquanto estava nessa casa, alguém, não soube quem, fez sua inscrição pela internet para tentar uma vaga de estágio. Ficou sabendo da sua inscrição quando recebeu um telegrama. No início ficou desconfiada, pensando que era alguma intimação para comparecer à delegacia. Não queria assinar porque ficou com medo, pois, como disse, "acontece muita coisa ruim no mundo". Mas depois que assinou e leu, ficou muito feliz ao saber do trabalho.

Esse local de trabalho a encaminhou para fazer um curso profissionalizante. Assim, de segunda a quarta-feira, comparecia ao estágio e quinta e sexta-feira ia fazer curso de auxiliar administrativo, sempre no turno vespertino. No começo, não gostava do curso, faltava com frequência, mas depois passou a gostar. Antes, reclamavam para Simone sobre seus constantes atrasos no trabalho e no curso, dizendo que ela teria que ter responsabilidade. Depois de um tempo, ainda chegava atrasada, mas com menos frequência. Recebia por mês $\mathrm{R} \$ 290,00$, além de $\mathrm{R} \$ 300,00$ de vale-refeição. Com o dinheiro, Simone comprava produtos para ela, como creme hidratante.

\subsubsection{Instituição A}

Depois da Instituição A2, Simone foi transferida novamente para a Instituição A, que no momento estava em outro endereço. Era a sede da Unidade, onde ficavam os adolescentes que apresentavam maiores dificuldades em seguir as regras do abrigo e os novos acolhidos. Continuou a trabalhar nos Correios enquanto estava nessa Unidade.

Nesse período começou a namorar Fábio. Depois de dois meses, terminaram o namoro e cada um namorou outra pessoa, mas logo depois reataram o relacionamento. Após um tempo, Fábio foi cumprir medida socioeducativa de internação por ato infracional. 


\subsubsection{Instituição B}

Simone foi transferida da Instituição A para a Instituição B aos 17 anos de idade. Ela nunca soube o motivo da transferência. Assim, ela estava pela primeira, vez desde os 12 anos de idade, em outra instituição de acolhimento, pois nas transferências anteriores, as quais ela se mudava para uma Casa Lar, ocorriam entre locais da mesma instituição, onde ela já conhecia a equipe e as regras de funcionamento.

Com o dinheiro que recebia do estágio, fazia pequenas compras para si mesma, adquirindo produtos como roupas e cremes hidratantes. As roupas do abrigo eram de doação, precisava pedir aos funcionários quando precisava. Então, Simone preferia ela mesma comprar suas roupas, ainda que fossem caras. Havia muitas diferenças da Instituição A: uma delas era a comida, que era melhor na Instituição B. Uma cozinheira preparava as refeições para os acolhidos.

O diretor Danilo não falava com Simone, pois ele estava com raiva dela. Isso começou depois que ele a viu fumando maconha dentro da Unidade. Ela estava esperando passar um tempo para conversar com o diretor, pois, como ela estava errada, não podia chegar com "muita razão" para falar com ele. A Instituição B ficava numa localidade onde era fácil conseguir drogas.

Fazia um tempo que Simone não visitava sua irmã, pois seu namorado Fábio tinha ciúmes dela e não a deixava ir. Ela já havia convidado ele para ir com ela, mas ele se recusou. Fábio havia sido transferido da internação do sistema socioeducativo, por ter cometido algum ato infracional, e estava na semiliberdade, podendo sair do local somente aos finais de semana para se encontrar com Simone. 


\subsubsection{Família na atualidade}

Na família de Simone, na época da última entrevista, moravam na mesma casa o pai, a moça que ele engravidou, seu irmão, o filho que nasceu e a mãe dessa moça. Vale lembrar que a mãe da madrasta era a madrasta anteriormente, antes do pai de Simone se envolver com a filha dela. A irmã de Simone mantinha contato com todos eles, mas Simone somente conversava com seu pai. A irmã de Simone ainda morava no mesmo local, e Simone iria visitá-la no final de semana seguinte à entrevista para visitar seu sobrinho.

Seu pai não vivia tranquilo em casa, pois ele voltou a fazer uso de álcool e drogas. Ele fumava maconha, como Simone, mas também usava e vendia cocaína. Ele trabalhava em um bar e conhecia "altos" traficantes, referindo-se a traficantes respeitados na região.

Simone perdeu o contato com os irmãos José e Joaquim porque seu celular estragou, ela o lavou junto com a roupa. Ainda tinha o número do seu tio, mas preferia não ligar, porque era só ela que ligava, seus irmãos nunca a procuravam. E ainda, quando telefonava, seu tio ficava perguntando o que ela estava fazendo, que barulho era o que ele estava ouvindo no fundo da ligação, ao que Simone não gostava. Ela estava com 16 anos, os gêmeos com 15 e sua irmã, a qual visitava com mais frequência, 17 anos. 


\subsection{NÍVEL TEMÁtICO 1: TENSÃO ENTRE A INSTITUIÇÃO DE}

\section{ACOLHIMENTO E A RUA}

A partir das informações oriundas da análise descritivo-cronológica da história de vida de Simone, realizou-se a primeira análise temática dessa participante, na qual buscou-se identificar elementos da relação entre a instituição de acolhimento e a rua, relação essa que muitas vezes apareceu de maneira tensa e conflituosa. Esse tema se sobressaiu na história de Simone, pois identificou-se um trânsito dela em vários locais de moradia e uma dificuldade de pertencimento, após a morte da mãe. Essa experiência anterior ao acolhimento institucional foi primordial para marcar seu modo de ser e estar na instituição, conforme apresenta-se a seguir. Assim, a discussão deste capítulo busca maior compreensão da relação que muitos adolescentes em situação de acolhimento fazem entre a instituição e a rua, considerando que a história de vida de uma pessoa representa, em alguma medida, a história de outros sujeitos que também fazem parte do mesmo contexto e vivem situações semelhantes.

A fim de nortear essa análise, utilizou-se os indicadores propostos por Parazelli (2002a), que sugerem o quanto um local é atrativo ou não a determinada pessoa. No caso desta pesquisa, buscou-se compreender a atratividade tanto da unidade de acolhimento, quanto da rua, tendo em vista o trânsito de alguns adolescentes entre esses dois espaços. Considerou-se que a percepção e interpretação subjetivas de uma situação, direcionam os modos de utilização e ocupação de determinado espaço. Pode ocorrer então, certa tensão entre esses modos de utilização e ocupação e o que está previsto, programado para determinado local. Por exemplo: uma unidade de acolhimento foi criada para receber crianças ou adolescentes que estejam sob medida protetiva judicial, no intuito de promover sua reintegração familiar e/ou comunitária. Mas pode ocorrer uso e tráfico de drogas no interior de uma Unidade de Acolhimento, sendo esse um modo de utilização destoante do modo 
previsto, podendo levar a uma série de tensões e conflitos entre os acolhidos e a equipe profissional da instituição.

Nesse contexto, para um espaço ser atrativo (Parazelli, 2002a), é importante que haja reciprocidade nas relações que se estabelecerem, confiança e certa indeterminação nas regras do local, com a criação de respostas conjuntas frente às situações de tensões. É um local intermediário entre elementos subjetivos, tais como percepções e projeções, e elementos objetivos, o que inclui o que foi programado para o local e o grau de tolerância e repressão ali presentes. A partir desses elementos, buscou-se compreender a história de vida de Simone.

\subsubsection{A busca do pertencimento}

A infância de Simone pode ser dividida em dois momentos: antes e depois da morte de sua mãe, quando Simone estava com 8 anos de idade. Percebe-se que no primeiro momento, a família mantinha certa estabilidade nas relações, com reuniões em todos os finais de semana para se alimentarem e se divertirem. Havia fartura de comida e bebida alcóolica, e Simone já fazia uso dessas bebidas junto à família. Para ela, ficar em casa era algo prazeroso, ela se sentia pertencendo àquele grupo, o que Parazelli (2002a) chamou de espaço transicional. Nesse contexto, tem-se certa confiança nas relações, reciprocidade e a indeterminação das regras, aparecendo, nesse caso, com Simone ingerindo bebidas alcóolicas ainda criança. A não determinação de certas regras pode ser prejudicial ao sujeito, sendo importante, segundo o autor, que haja regras, mas que elas possam ser reavaliadas conforme situações não esperadas vão se fazendo presentes. Assim, as condições relacionais da família de Simone, antes da morte de sua mãe, indicam que esse contexto era atrativo para ela.

Mas, desde essa época, Simone desconfiava que não era filha de seu pai, pois tinha a impressão de que ele é que a havia queimado no rosto por esse motivo, deixando uma marca permanente, mas que ela nunca perguntou a ninguém sobre esse assunto. Ficava com raiva 
quando a questionavam sobre a marca, pois, dizer o que ela sabia sobre o assunto significava assumir que seu pai havia sido violento e que ela não era filha legítima de seu pai. Era balançar, colocar à prova a convivência familiar tranquila que até então, ela dizia vivenciar. Pode-se inferir, também, que Simone queria evitar qualquer sentimento de inferioridade frente ao outro (Gaulejac, 2006m), caso essa história se tornasse pública, por ser uma filha ilegítima, bem como o sentimento de vergonha por ter um pai que, ao invés de protegê-la, havia queimado seu rosto. Então, Simone ou brigava com quem a questionava ou desconversava, criando outra história sobre a origem da queimadura.

Após a morte de sua mãe, a convivência entre os membros da família de Simone se enfraqueceu, com a entrada da madrasta na família e a gravidez da filha dessa madrasta pelo pai de Simone. Quando a madrasta terminou o relacionamento com seu pai, Simone resolveu morar com ela, tendo em vista que, para ela, seu pai não gostava dela. Depois de um tempo, ela foi morar com um traficante, quando teve acesso a vários tipos de drogas e manteve relações sexuais com homens mais velhos, indicando que talvez ela tenha vivenciado situações de exploração sexual. Depois voltou para a casa do pai, mas só dormia no local, pois passava o dia fora, consumindo drogas. Em seguida, como seu pai queria matá-la, Simone foi morar com sua irmã, que na época já era casada e morava com o companheiro na casa dos sogros.

Essas constantes mudanças de Simone mostram a dificuldade dela em pertencer a algum local por muito tempo. Como seu pai mantinha uma relação superficial e, por vezes, de indiferença em relação a ela, Simone buscou outros locais onde pudesse ser acolhida, aceita, vivenciando situações de drogadição, exploração sexual, festas e relacionamentos com amigos que pudessem favorecer uma afirmação de si mesma. Havia, também, uma fuga em relação a figuras de autoridade, tendo como referência, a figura distante afetivamente e muitas vezes hostil de seu pai (Parazelli, 2002b). Esse não pertencimento de Simone a um grupo, esse não 
lugar social em que ela se encontrava, após a morte de sua mãe, vai conduzi-la ao acolhimento institucional, local onde outros adolescentes, que também vivenciaram dificuldades semelhantes de relacionamento em suas famílias, se encontravam.

\subsubsection{Drogas e diversão: a busca do reconhecimento e do pertencimento coletivo}

Assim que Simone chegou à Instituição A, precisou se impor, ser reconhecida frente aos demais acolhidos como alguém que eles tinham que respeitar, após ser chamada por um adolescente pejorativamente de "folgada". Ela disse de onde vinha, local esse reconhecido por haver muitas gangues e tráfico de drogas. Simone havia internalizado em sua identidade, a partir de sua vivência da infância, o modo de ser e estar no mundo que perpassava pelo pertencimento a grupos que faziam uso e tráfico de drogas. Como afirmou Gaulejac (2006n), o processo de construção identitária ocorre ao longo da vida, no qual são internalizados elementos do contexto social, cultural e ambiental vivenciados pela pessoa, além de ser influenciada pela posição social que a pessoa ocupa, pelo status social gerado, por expectativas e hábitos relacionados. Duas necessidades são fundamentais no processo de construção identitária: necessidade de valorização e de identificação a um grupo (Gaulejac, 2006n). Então, após uns dias na unidade de acolhimento, Simone se utilizou das mesmas estratégias que desenvolveu após a morte de sua mãe, ao não se sentir acolhida em casa com seu pai: busca de pertencimento a grupos envolvidos com drogas e diversão. De alguma forma, ele procurava restaurar momentos semelhantes ao que havia vivenciado em casa, junto a sua mãe, quando era prazeroso ficar em casa, com momentos marcados por muita diversão e uso de bebida alcóolica.

Então, para suportar estar acolhida num local onde não estava voluntariamente e onde as situações que a marcaram negativamente estavam relacionadas a sucessivos encaminhamentos à Delegacia da Criança e do Adolescente, quando Simone não respeitava as 
regras da instituição, ela passou a usar drogas com os demais acolhidos, além de buscar ser reconhecida por esses como alguém que merecia respeito, por ter passado sua infância em um local reconhecidamente violento. Esse grupo a influenciou, como ela mesma disse, a começar sua vivência na rua, para onde ia a fim de usar drogas, roubar, vigiar carro e praticar mendicância, no intuito de conseguir dinheiro e comprar mais drogas. Assim, repetindo a vivência de quando sua mãe morreu, continuar a usar drogas ajudava Simone a viver coletivamente, somando-se, no acolhimento, a prática de atos infracionais. Como indicou Parazzeli (2002c), quando o adolescente vivencia certa forma de abandono de seus pais, no caso de Simone, após a morte de sua mãe, representada pela apatia afetiva de seu pai em relação a ela, ele apresenta um percurso marcado por consecutivas rupturas sociais relacionadas aos seus locais de moradia, evitando a ameaça da inexistência social que se apresenta depois da vivência de abandono. E como afirmou Gaulejac (2006a), a falta de estima dos outros coloca à prova a auto-estima, influenciando sua relação com o mundo. Assim, de forma semelhante às experiências de estar desempregado ou preso, estar acolhido institucionalmente pode apresentar uma imagem social negativa, marcada pela falta ou inadequabilidade. Para Simone, estar em uma instituição de acolhimento não era acolhedor afetivamente, sendo necessário então, para ela, buscar pertencer a outro grupo que lhe oferecesse esses elementos: acolhida e reconhecimento.

Simone afirmou que muitos adolescentes preferem passar tempos na rua pela tristeza das instituições de acolhimento, por mais que não se tenha acesso com frequência a alimentação e a um local adequado para tomar banho. Mas o lado bom da rua estava relacionado ao poder brincar, rir e fazer amizades. Na rua se sentia feliz, e na instituição de acolhimento se sentia triste. Na visão dela, é pela tristeza das instituições que muitos preferem a rua. 
Outro ponto comparativo entre a rua e o acolhimento estava relacionado à existência de regras. Na unidade de acolhimento havia regras, na rua também, mas de forma diferenciada. A regra da rua dava-se em relação ao respeito às pessoas. Como exemplo, Simone disse que quando uma pessoa tem um namorado na rua, outra pessoa não pode ficar querendo namorar a mesma pessoa. Se isso ocorre, "dá briga". Outras regras que existem na rua são: não roubar coisas do colega que também está na rua, não pegar droga do outro e não xingar a mãe de outra pessoa que também estava em situação de rua. Nesse ponto, a rua apresentava para Simone maior atratividade (Parazelli, 2002a), pela reciprocidade nas relações que ali se estabeleciam. Já na instituição, as regras relacionavam-se ao respeito ao funcionamento do próprio local, ao cotidiano, aos horários que os acolhidos deveriam seguir, denotando um significado mais impessoal.

Mas, ao mesmo tempo, a instituição tinha uma função para Simone, pois mesmo quando estava na rua, buscava com outros acolhidos, por meio da grade, tanto cobertor, quanto comida. Nesse sentido, tem-se que a unidade de acolhimento apresentava a função de suprir necessidades materiais de Simone (Blondel, 1994), enquanto o grupo de acolhidos e outros adolescentes que estavam na rua, supriam sua necessidade afetiva, de reconhecimento e de pertencimento. Ela pontua que teria voltado com mais frequência à instituição, caso as regras para esse retorno não tivessem se tornado mais restritas, com a obrigação de que os acolhidos passassem pelo Conselho Tutelar, para serem encaminhados ao acolhimento, impedindo-os de procurarem diretamente a Unidade quando quisessem sair da rua. Por vezes, algumas regras dificultam ainda mais a vinculação entre o adolescente e a instituição. Mas pontua-se que Simone não resistia de todo a qualquer vinculação afetiva aos profissionais do acolhimento, pois, em um episódio, ela relata que a psicóloga que a acompanhava foi até o local onde se encontrava há três meses, na rua, para conversar com ela, quando ela então, após essa conversa, decidiu retornar à instituição. Assim, indica-se que o serviço de acolhimento 
precisa oferecer mais do que recursos materiais do que impor regras de funcionamento institucional, e sim, permitir certa reciprocidade nas relações entre os acolhidos e a equipe, que permita confiança mútua entre acolhidos e profissionais, além de certo grau de indeterminação das regras estabelecidas, a partir das demandas que se fazem presentes (Parazelli, 2002a).

Nesse meio tempo, seus dois irmãos gêmeos foram morar com um tio, que não aceitou Simone, afastando-a dos únicos membros da família aos quais se relacionava com frequência, já que visitava sua irmã ocasionalmente. Tem-se, com esse episódio, mais uma experiência de falta de estima em relação à Simone.

\subsubsection{Casa Lar: a ilusão de proximidade entre acolhido e profissional}

Após ser acolhida na Instituição A, caracterizada por contar com várias casas em um único espaço físico, Simone foi transferida para uma Casa Lar, sendo essa uma modalidade de acolhimento caracterizada por uma casa comum que ficava em uma comunidade, acolhendo até 10 crianças ou adolescentes. No local anterior, somando-se os acolhidos de todas as quatro casas, havia cerca de 40 acolhidos em um mesmo terreno, que compartilhavam da mesma área comum da instituição. A configuração de Casa Lar permitiria, assim, maior proximidade relacional entre os profissionais da instituição e os acolhidos.

Da primeira Casa Lar em que Simone ficou, ela foi transferida dentro de poucos meses para outra Casa Lar, tendo em vista que, segundo a psicóloga que a acompanhava, a adolescente havia feito amizade com outros adolescentes da comunidade que faziam uso de droga, o que a profissional reprovava. Para a psicóloga, Simone não aproveitava as oportunidades que lhe eram oferecidas pelo acolhimento. Um episódio ilustrativo dessa situação diz respeito ao desejo de Simone de ir a uma festa com esses amigos. A psicóloga ficou de conversar com ela antes da referida festa, o que não ocorreu. Simone foi mesmo 
assim ao evento e, ao retornar à Casa Lar, foi impedida de entrar no local, levando-a a dormir na rua por alguns dias. Buscando contornar a situação, Simone foi transferida para outra Casa Lar, também pertencente à Instituição A. Destaca-se nesse episódio que Simone continuava a se relacionar com grupos locais de adolescentes que faziam uso de drogas. E os profissionais, avaliando de antemão que se tratava algo prejudicial à Simone, tomavam providências para afastá-la desses grupos, sem considerar os possíveis significados dessas relações para ela. Mas para Simone, as drogas estavam ligadas à diversão, quando também podia ficar acordada até quando quisesse, indicando que momentos prazerosos na instituição de acolhimento, não eram frequentes. As regras relacionadas ao cotidiano precisavam ser seguidas de forma rígida. Mas Simone sabia que quanto mais se ficava na rua, mais era difícil de o adolescente sair dessa situação, precisando de ajuda para tal. Ela observou que isso ocorreu com um colega que saiu da instituição de acolhimento e foi para a rua, tornando-se um "viciado na rua". Outro ponto observado por ela estava relacionado aos adolescentes que encontravam-se em situação de rua: todos já haviam sidos acolhidos em alguma instituição. Mas, para ela, o acolhimento era necessário, pois muitas crianças são abandonas por seus pais e precisam ser encaminhadas para algum local.

Considerando as indicações de Parazelli (2002a), a percepção em relação a determinada situação e os significados atribuídos direcionam algumas reações dos sujeitos. Assim, indica-se que os profissionais não acessavam os possíveis significados de Simone sobre sua relação com grupos que faziam uso de droga, buscando agir de forma a impedir seu comportamento de sempre buscar integrar esse tipo de grupo. De forma geral, ao não buscar o significado de certos comportamentos de adolescentes acolhidos, os profissionais não obtêm sucesso ao tentar mudar esses comportamentos, tais como envolvimento com drogas ou grupos violentos, frustrando-os em relação à sua atuação profissional. Ao contrário, buscavam aumentar ações de controle e vigilância sobre os adolescentes, na tentativa de fazer com que 
seguissem as regras da instituição. Mas, como um efeito "bola de neve", quanto maior era o controle, mais se aumentava a desconfiança dos adolescentes em relação aos profissionais e, seus comportamentos que infringiam regras institucionais também aumentavam, prejudicando a reciprocidade das relações entre equipe e acolhidos.

Em casos extremos, os profissionais acionavam a polícia, como ocorreu no episódio em que Simone e seus colegas saíram da Casa Lar para fazer uso de maconha. Um profissional achou uma quantidade de maconha na mochila de um desses adolescentes, enquanto eles estavam fora da instituição, não permitindo que eles entrassem na Casa quando retornaram da rua. O profissional, então, chamou a polícia e os adolescentes, incluindo Simone, foram encaminhados à Delegacia da Criança e do Adolescente, sendo registrada ocorrência policial. De forma geral, para Simone, os profissionais somente agiam quando a situação saía do controle, por meio da intervenção policial. Eles não se importaram quando os adolescentes diziam que algo estava errado, quando pediam ajuda para resolver situações mais simples. O máximo que faziam era dizer que chamariam a polícia, caso continuassem a desrespeitar as regras da instituição.

Ao longo do período em que ficou acolhida na Instituição A, Simone foi perdendo a vontade de frequentar a escola. Para ela, era muito vergonhoso ir com o carro da instituição que, por mais que não tivesse o nome da unidade de acolhimento, era caracterizado como um veículo institucional. Além do mais, ela sempre chegava atrasada, pois o motorista nunca a buscava na hora. Esse sentimento de vergonha, que influenciou Simone a ponto de desistir da escola, indica sua percepção de inadequação a esse contexto e pode ser explicado a partir das considerações de Gaulejac (2006j). Para ele, a escola que poderia ser um local de segurança e proteção, frente a uma vida marcada por dificuldades, torna-se um local de rejeição e de humilhação para alguns alunos. Era dessa forma que Simone percebia o contexto escolar, dificultando sua permanência nesse contexto. Ainda, ela afirmava que a escola era a melhor 
opção para a pessoa pobre, mas quando essa pessoa completava 18 anos, tinha que deixar a escola para trabalhar e ter uma renda financeira para se sustentar. Então, pode-se indicar que Simone, que estava com 17 anos à época da entrevista, não via significado para a escola, pois, ao completar 18 anos, teria que adquirir independência financeira, já que teria que sair da unidade de acolhimento. Esse tipo de instituição era destinada a crianças e adolescentes até 17 anos e 11 meses de idade.

Ainda na segunda Casa Lar da Instituição A, Simone foi inscrita para fazer estágio, quando recebia uma quantia em dinheiro e utilizava esse valor para comprar produtos para ela, como creme hidratante, deixando-a muito satisfeita. Mas, mesmo nessa condição, ela continuava a se envolver com grupos que faziam uso de droga. A fim de evitar que Simone abandonasse o estágio, ela foi transferida novamente de local, voltando para a sede, aqui denominada Instituição A, onde ficavam os adolescentes que apresentavam mais dificuldades em seguir as regras da unidade de acolhimento. Nesse local, ela começou a namorar um adolescente, que, um tempo depois, havia sido encaminhado para cumprir medida socioeducativa de internação, por ter cometido ato infracional. Mas Simone ficou acolhida nesse lugar somente alguns meses, sendo transferida para a Instituição B, sem maiores explicações.

\subsubsection{Drogas: da rua para o interior da instituição}

Simone foi transferida da Instituição A para a Instituição B aos 17 anos de idade, sem que nunca tivessem lhe dito qual era o motivo. Desde que havia sido encaminhada para uma instituição de acolhimento, essa era a primeira vez em que ela estava num local totalmente novo, com pessoas e regras diferentes da Instituição A. Mas havia uma vantagem: a alimentação era preparada por uma cozinheira, ao invés de ser entregue pronta, como ocorria na instituição anterior. Assim, as refeições eram mais saborosas. 
Nesse novo local, Simone conseguia drogas com facilidade, chegando a usar maconha dentro do quarto, o que deixou o diretor irritado com ela, mas a equipe não chamou a polícia, como era de costume na Instituição A. Então, ao comparar o comportamento de Simone entre as duas instituições, percebe-se que nessa segunda Unidade, ela passou a fazer uso de drogas dentro do próprio quarto, diferentemente da Instituição A, quando era preciso sair para a rua a fim de fazer uso de substâncias psicoativas. Utilizando termos de Parazelli (2002a), o modo de utilização desse novo espaço de acolhimento ocorria de forma diferente do espaço anterior, indicando que a percepção de Simone quanto a esse novo local, parecia diferir da percepção do espaço anterior. Mas assim como ocorria na Instituição A, os profissionais procuravam proibir o uso de drogas pelos acolhidos, sem observar qual a função, qual o papel da droga na vida desses adolescentes.

Sobre o futuro, a temática da droga apareceu novamente para Simone. Ela gostaria de ser policial federal para trabalhar na fronteira do país e ficar com parte da droga apreendida de traficantes, além de cobrar um valor em dinheiro para permitir que essa pessoa voltasse ao seu país de origem. Percebe-se certa ingenuidade de Simone nesse caso, pois ela diz que se utilizaria dos mesmos mecanismos que aprendeu na sua relação com o tráfico de drogas, sem considerar os riscos que esse comportamento pudesse lhe causar.

E, apesar de passar toda sua infância em unidades de acolhimento, a busca de pertencimento de Simone por meio de grupos que lhe proporcionassem acesso a drogas e diversão, como que buscando restaurar momentos que viveu com sua mãe, não foi ressignificado. Nesse sentido, a rua era mais atrativa do que a instituição, essa última sendo caracterizada como um local de tristeza. Mas, mesmo assim, o acolhimento institucional ainda tinha uma função para Simone, mesmo que se apresentasse de forma mais utilitarista. Nesse ponto, observa-se que havia uma elo que ligava a adolescente ao acolhimento, que poderia ser 
trabalhado para que essa relação fosse de fato acolhedora, como o próprio nome da instituição sugere.

\subsubsection{Síntese}

Ao longo da análise da história de vida de Simone, observam-se alguns pontos marcantes em sua trajetória. O primeiro deles refere-se ao sentimento de pertencer à sua família, antes da morte de sua mãe, com muitos episódios marcados por diversão e uso de álcool. Com o falecimento da mãe de Simone, ela busca pertencer a outros grupos, pois a convivência com seu pai era marcada por conflitos ou por uma apatia deste em relação a ela.

Então, Simone passou a conviver com grupos que, de alguma forma, forneciam a ela momentos de diversão e acesso a drogas ilícitas.

Ao ser acolhida em uma instituição, ela continuou sua busca de pertencimento, passando a permanecer momentos na rua, próximo à Unidade de acolhimento, quando conheceu outros adolescentes que faziam uso de drogas. A instituição tinha uma função para ela, mas estava relacionada mais ao fornecimento de um local para dormir, tomar banho e à alimentação. Os profissionais não buscaram conhecer o significado da busca constante de Simone por grupos que fizessem uso de drogas, transferindo-a de local algumas vezes, para que ela se afastasse desses grupos. Quando estava com 17 anos de idade, foi transferida para outra instituição, o que não impediu que Simone fizesse uso de drogas.

Assim, após a morte de sua mãe, Simone ficou em um movimento de pertencimento/ não pertencimento a vários grupos. E mesmo quando esteve acolhida institucionalmente, ela manteve esse movimento, transitando entre a rua e o acolhimento. 


\subsection{NÍVEL TEMÁTICO 2: REPRESENTAÇÃO IMAGINÁRIA A PARTIR DOS DESENHOS}

Em relação à segunda análise temática da história de vida de Simone, o foco ficou com a representação imaginária de elementos de sua trajetória, a partir dos desenhos elaborados pela participante, durante as entrevistas. Nesse sentido, assim como ocorreu com o participante Marcos, foram consideradas três perspectivas: a de Simone, a que emergiu do diálogo entre a participante e a pesquisadora sobre as representações gráficas e, ainda, a da pesquisadora, a partir do nível descritivo-cronológico e da análise temática sobre a relação entre a instituição de acolhimento e a rua. Sendo assim, segue a análise realizada a partir de cada produção gráfica da adolescente participante. Os desenhos foram agrupados de acordo com cada momento em que foram elaborados, seguindo a ordem de sua produção, independente se foram feitos na mesma entrevista ou não.

\subsubsection{Momento 1}

No primeiro encontro, Simone começou a contar a história de sua infância e ficou, durante esse momento, segurando e cuidando de um menino de 1 ano e alguns meses, que estava acolhido na Casa Lar. Percebe-se que, desse modo, ela representou a cena de uma cuidadora e de seu cuidado, indicando a relação que havia entre ela e sua mãe. Simone escolheu narrar sua história no próprio quarto, sob a própria cama. Seu papel para o menino desenhar, enquanto narrava vivências de sua infância, ao mesmo tempo em que cuidava para ele não se machucar. Quando começou a falar da adolescência, entregou o menino para um cuidador social da casa cuidar e passou a desenhar em vários papéis, sem nenhuma forma definida. Pode-se indicar que Simone representa,_dessa forma, a interrupção do cuidado que recebia na infầncia por sua mãe, quando essa morreu. Interessante observar que Simone, para falar da própria infância, 
escolheu cuidar de outra criança que, provavelmente, facilitou que ela expressasse situações vivenciadas por ela nessa fase de vida. Indica, talvez, a necessidade de Simone da presença de algo concreto para que pudesse expressar momentos difíceis que viveu. Após esse primeiro momento, Simone desenhou aleatoriamente enquanto falava, conforme segue a seguir.

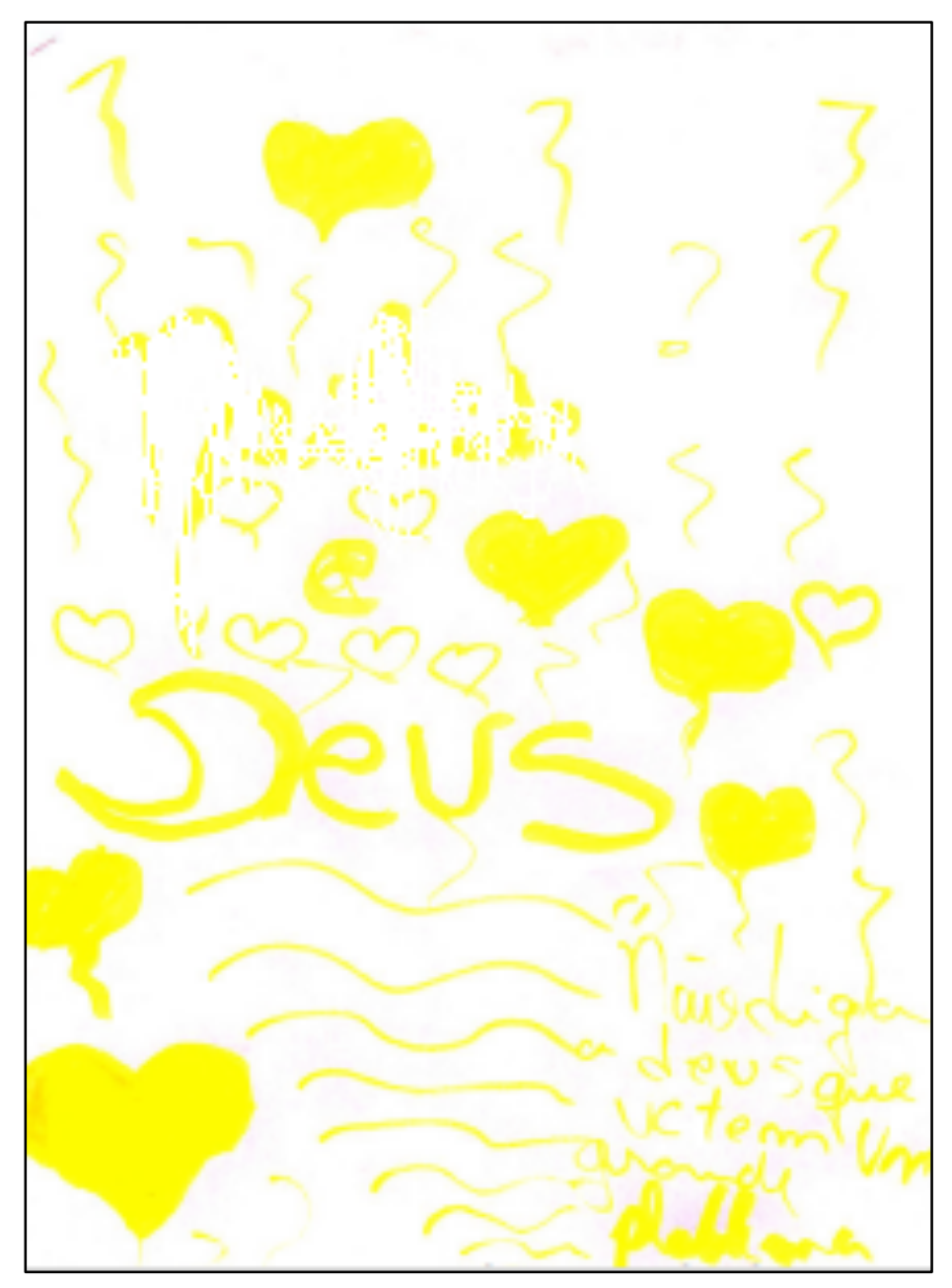

Figura 24 - Momento 1 


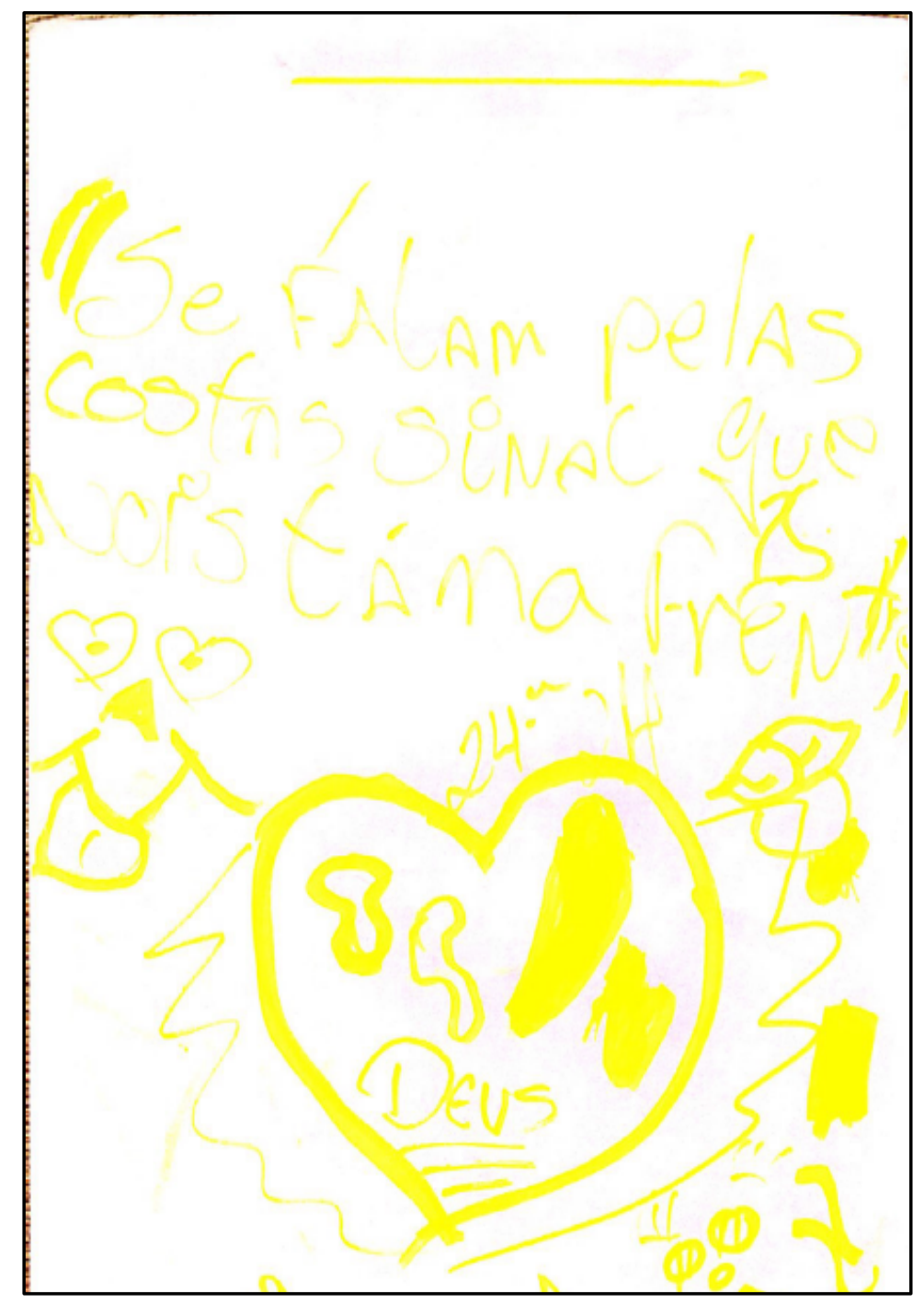

Figura 25 - Momento 1

Na figura 24, Simone escreveu "Simone e Deus", com alguns corações em volta, e a frase: "não diga a Deus que você tem um grande problema". Na figura 25, além de escrever "Deus" dentro de um coração, colocou a seguinte frase: "se falam pelas costas sinal que nóis tá na frente", frases essas do tipo compensatórias de uma situação não privilegiada socialmente, na qual Simone se encontrava. Essas imagens indicam a confiança em um ser que pudesse protegê-la, ao mesmo tempo que teria que conseguir resolver seus problemas sozinha, pois não poderia compartilhar suas dificuldades com Deus. Indica também uma autoconfiança para encarar as críticas que recebia pois, certamente, estava à frente e em melhores condições do que as pessoas que a criticavam. Então, apesar de uma história de vida 
marcada pela busca de pertencimento coletivo, pela busca de reconhecimento, Simone conseguia identificar seus pontos positivos e fortes.

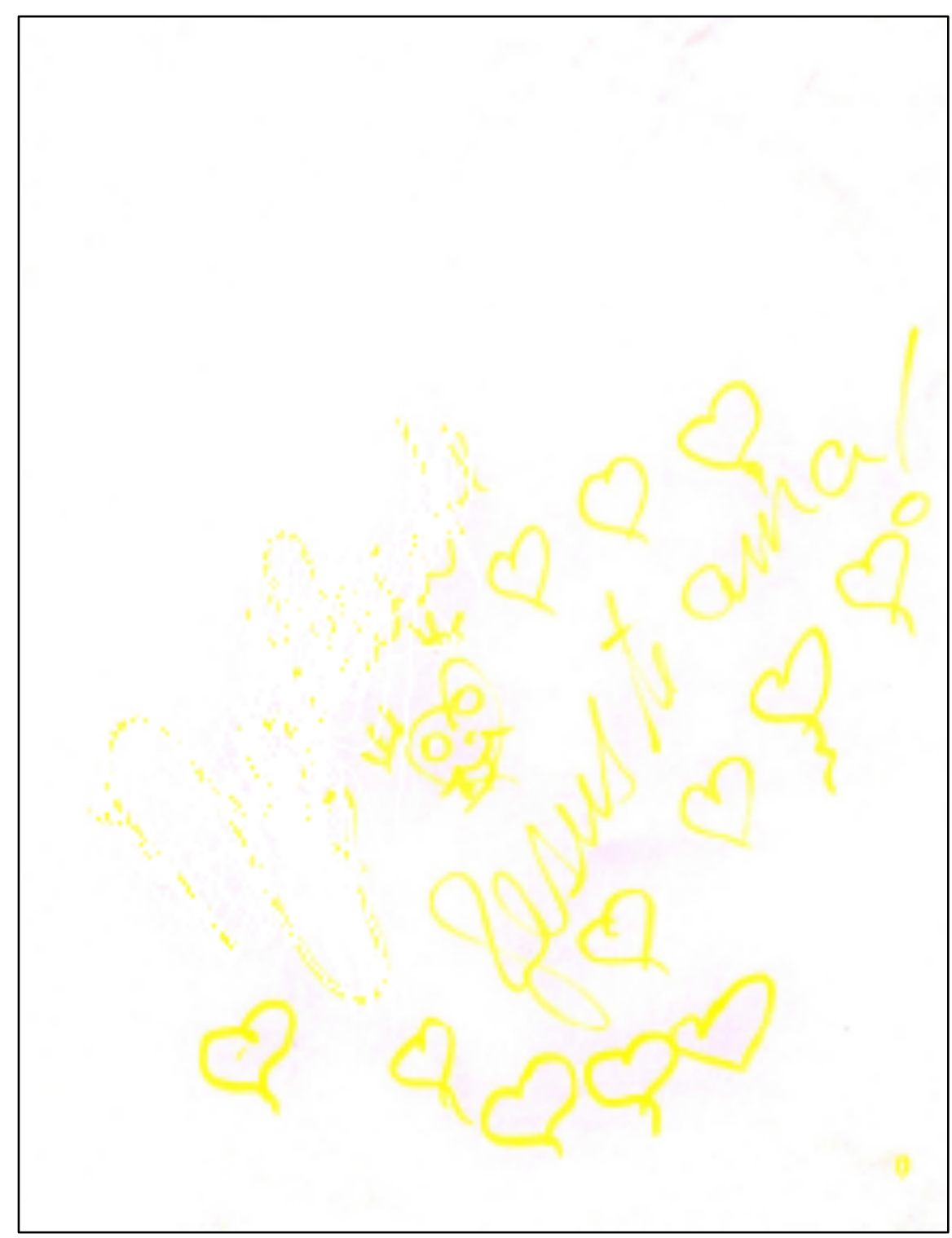

Figura 26 - Momento 1 


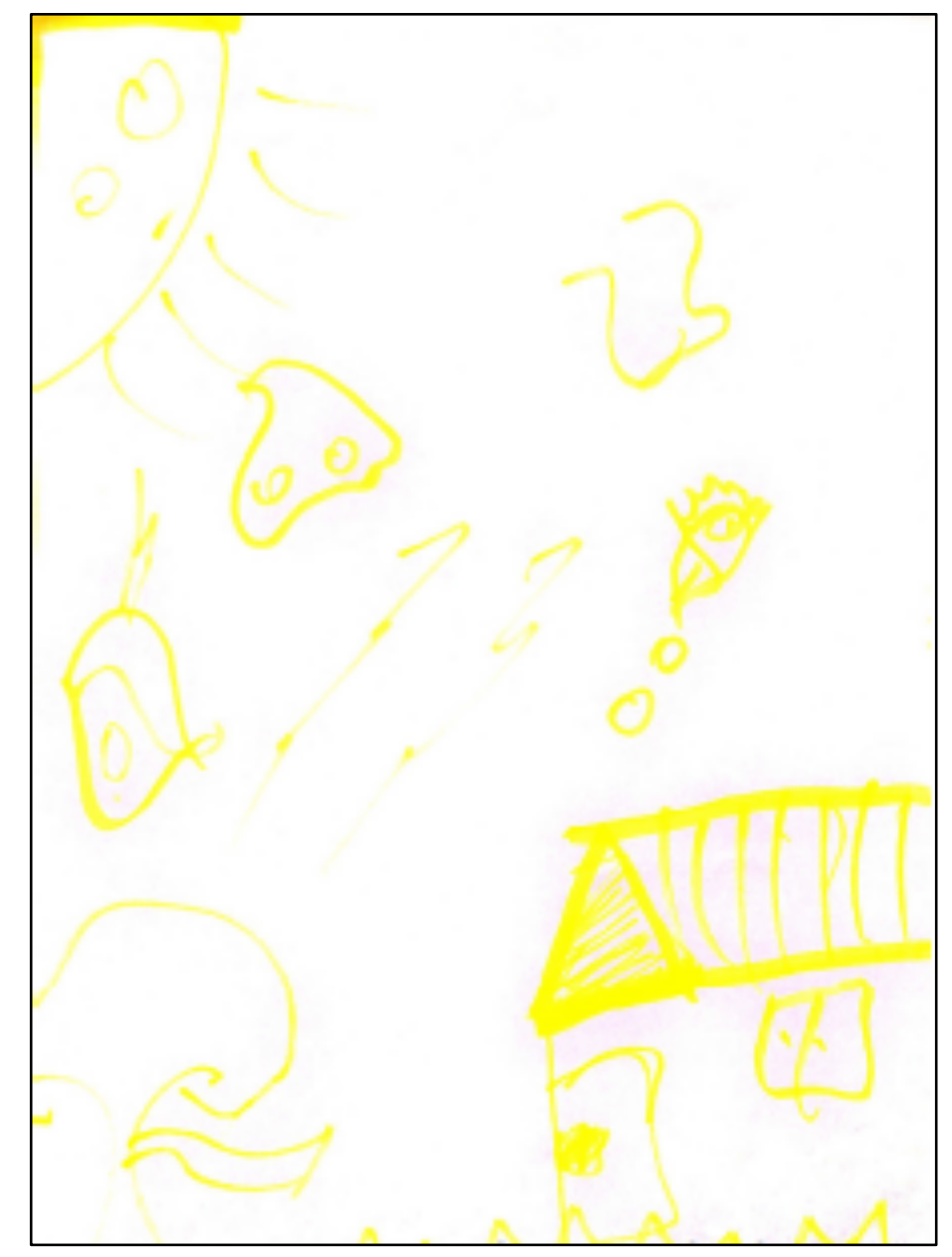

Figura 27 Momento 1

Na Figura 26, Simone escreveu "Simone Jesus te ama", em meio a corações e, na Figura 27, uma casa ao lado de uma árvore deitada, ambas sob o sol e algumas figuras disformes. Em momento algum Simone apresentou em sua história de vida algo relacionado à religião, mas pelos desenhos, entende-se que ela via Deus e Jesus como seres que pudessem protegê-la de qualquer situação ruim, ao mesmo tempo em que essa colocação denota uma forma estereotipada socialmente, de busca de proteção, utilizada quando não se consegue agir para mudar algo a seu favor. É uma forma de justificar e compensar a situação desfavorável socialmente na qual Simone se encontrava, estando acolhida em uma instituição. No quarto desenho, passa-se a impressão que a casa representada está em meio a um vendaval, com uma árvore ao lado suspensa no ar, na horizontal, e algumas figuras disformes no ar. Quando fez 
esse desenho, ela falava sobretudo de sua vivência após a morte de sua mãe, experienciada no fim da infância e início da adolescência, indicando, por meio desse desenho, que foram momentos movimentados e de turbulência, que mudou a ordem das coisas. Observa-se assim, que Simone se comunica em três níveis: verbal, dramático (quando encena cuidado e interrupção desse cuidado pela mãe, na sua relação com um menino da instituição de acolhimento, no momento da entrevista) e gráfico, sendo importante para ela que isso ocorra, o que facilitaria a expressão de sentimentos, percepções e de episódios aos quais viveu.

\subsubsection{Momento 2}

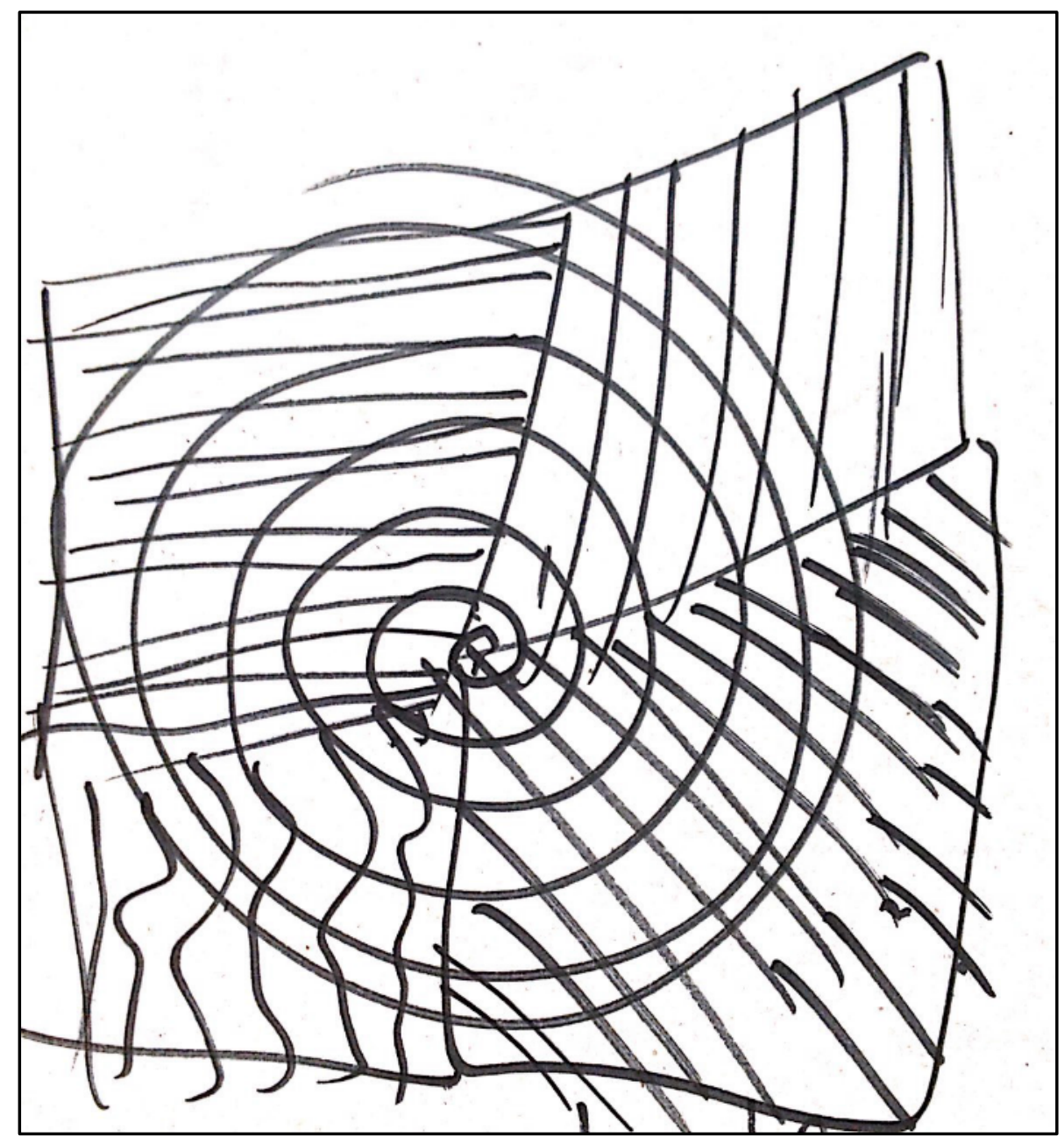

Figura 28 - Momento 2 
Simone fez o desenho anterior (Figura 28) enquanto falava, no segundo encontro, e disse que gostava de desenhar daquela forma, sem fazer maiores comentários. Era um quadrado, feito no centro do papel, ocupando quase todo o espaço da folha, com um espiral dentro e vários riscos cortando o desenho como um todo. Essa ilustração sugere, a partir da história narrada por ela, que Simone, apesar de vivenciar uma história tensa após a morte de sua mãe, conseguia manter-se minimamente centrada, buscando grupos aos quais pudesse pertencer, "se encaixar". A divisão do grande quadrado em quatro partes, parece indicar os vários grupos aos quais ela buscou pertencimento. E a espiral no centro do desenho, lembra o movimento de vendaval da Figura 28, indicando talvez que, apesar da reviravolta que sua vida deu após a morte de sua mãe, Simone buscou manter-se centrada e criando formas de sobreviver e se proteger. Ao mesmo tempo, essa ilustração lembra uma teia de aranha, um emaranhado de elementos que a prendem, deixando-a em uma situação contraditória: ser proativa, buscar alternativas, buscar outros grupos $\mathrm{X}$ manter-se em um quadrado, em uma caixa, ao tentar reviver um cuidado que foi perdido com a morte de sua mãe.

Em seguida, pegou outra folha e fez outro desenho livre, mostrando outra forma de desenhar (Figura 29), como ela afirmou. Faz um quadrado novamente, dividindo-o em quatro e fez bolas, quadrados e triângulos em seu interior, com algumas setas em sentido contrário ao quadrado. Nessa ilustração, observa-se que existem outras direções possíveis para Simone, com possibilidade para que siga adiante e conquiste outros espaços, para além de se encaixar em determinados formatos sociais pré-estabelecidos. Ao mesmo tempo, ao repetir os traços do desenho anterior, que ficam em um quadrado e que aparecem de forma repetidas, ela indica sua dificuldade em crescer, em seguir em frente, em sair de um "quadrado", pois está presa e voltada no sentido de desejar reaver o que já morreu, ou seja, o cuidado materno e uma situação familiar que, antes do falecimento da mãe, era minimamente coesa e acolhedora. 


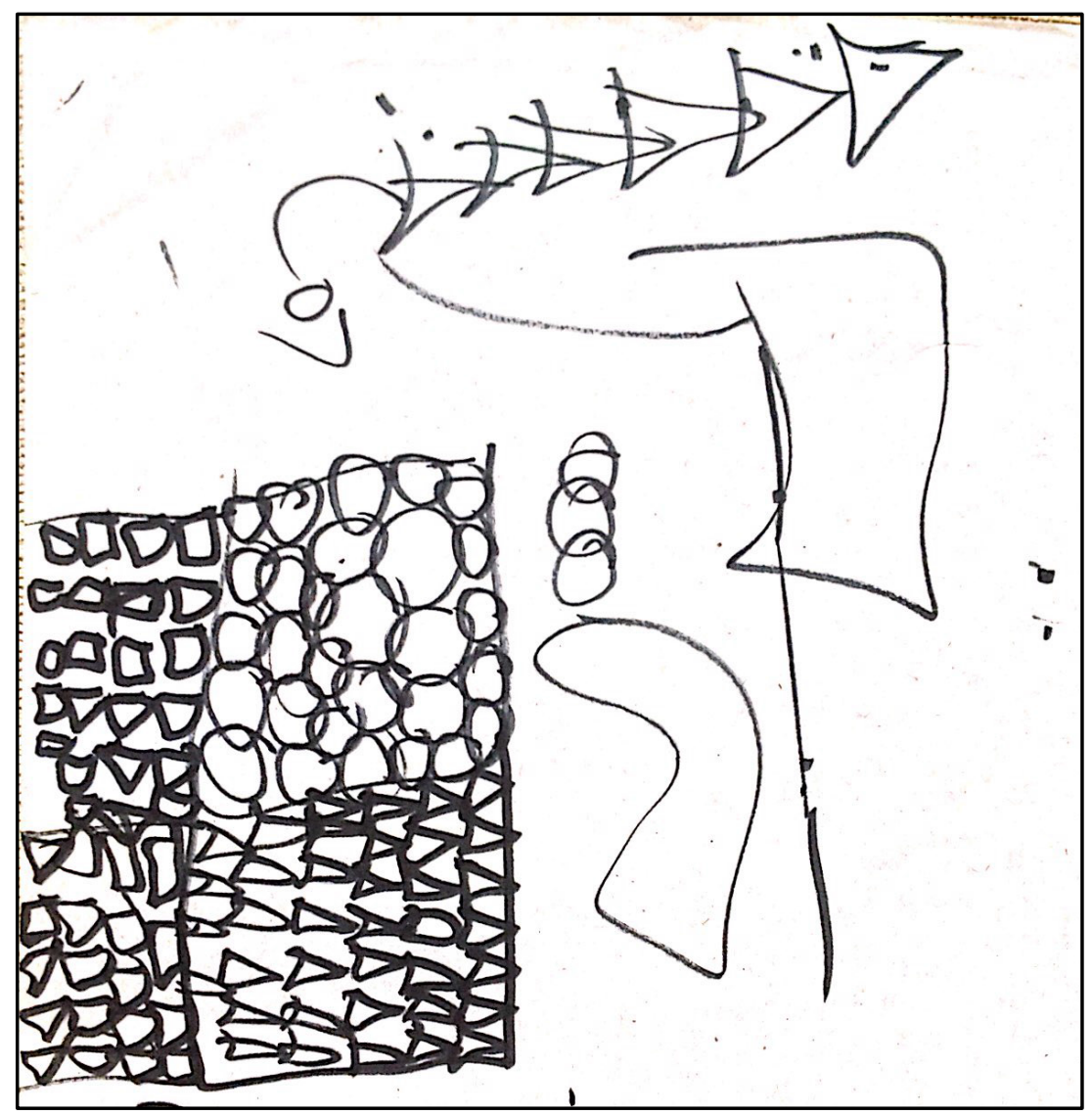

Figura 29 - Momento 2

\subsubsection{Momento 3}

Ao falar para Simone continuar a contar algo sobre sua história, no segundo encontro, a pesquisadora foi relembrando trechos de sua história, relatados por ela na primeira entrevista, mas Simone estava com dificuldade para ter ideia sobre o que narrar. A pesquisadora sugeriu então que ela desenhasse algo do que viveu, sendo essa ilustração mais organizada do que os desenhos anteriores, sugerindo que quando há intervenção no sentido da solicitação de que o adolescente desenhe algo, pode-se facilitar a organização de sua história, de episódios que vivenciou e que muitas vezes, ainda não havia percebido de forma consciente. Quando a pesquisadora falou da experiência de Simone com as drogas, após ter citado outros momentos, ela resolveu desenhar a maconha de antes e a maconha daquele momento, mas não conseguia começar. Então, disse que iria desenhar as drogas que conheceu 
e a pesquisadora sugeriu para ela dividir em antes e depois de ser acolhida em uma instituição, quando estava com 12 anos de idade. Nesse ponto, tem-se também o desenho como facilitador da fala, da expressão verbal pois, após o desenho, Simone pode falar de sua relação com as drogas. Interessante observar que, dentre as várias situações vividas por Simone, ela escolheu representar sua experiência com drogas, especialmente com a maconha, indicando a importância dessa droga na trajetória da adolescente.

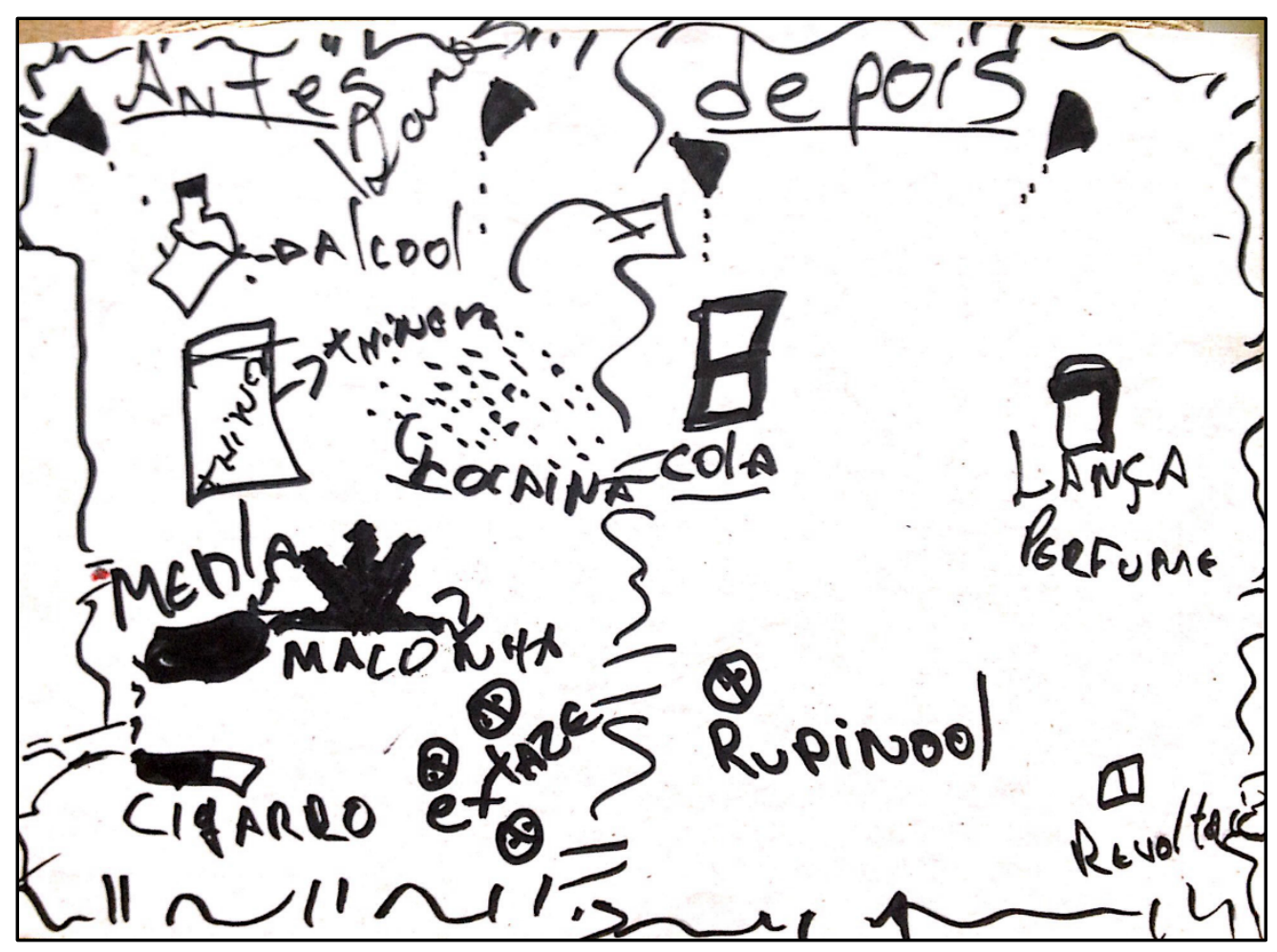

Figura 30 - Momento 3

Sobre as drogas que conheceu antes do acolhimento, Simone citou maconha ("a famosa maconha"), cigarro, cocaína, êxtase, merla e álcool, afirmando que provou todas essas e que era prazeroso. Depois do acolhimento, Simone conheceu o crack, dizendo que nunca provou essa droga, a cola de sapateiro, o lança perfume, o roupinol e o rivotril. No momento da entrevista, ela disse que fumava cigarro e maconha de vez em quando. Percebe-se então que a trajetória de Simone sempre foi marcada pela presença de muitas drogas, sendo que 
depois de ser acolhida, conheceu outras. Um ponto interessante a ser ressaltado é a palavra "revolta", escrita na segunda parte do desenho, como se fosse um tipo de droga que ela conheceu.

Ao longo de todas as entrevistas, Simone praticamente não expressou sentimentos relacionados ao que viveu, salvo nesse desenho, marcando bem como se sentiu ao ser acolhida em uma instituição, ou seja, revoltada. Comparando-se às drogas, a revolta pode ser vista nesse contexto como algo que causa dependência, difícil de deixar, mas que, ao mesmo tempo, leva a algum tipo de prazer. Talvez, por meio dessa revolta é que Simone conseguia se impor frente aos demais acolhidos e adolescentes que conheceu na rua, bem como frente aos profissionais do acolhimento, para se defender e evitar que fosse "enquadrada" a todo custo a situações ou padrões que não concordava, seja na instituição, seja na rua, sempre buscando alguma saída, como representou na Figura 29.

\subsubsection{Momento 4}

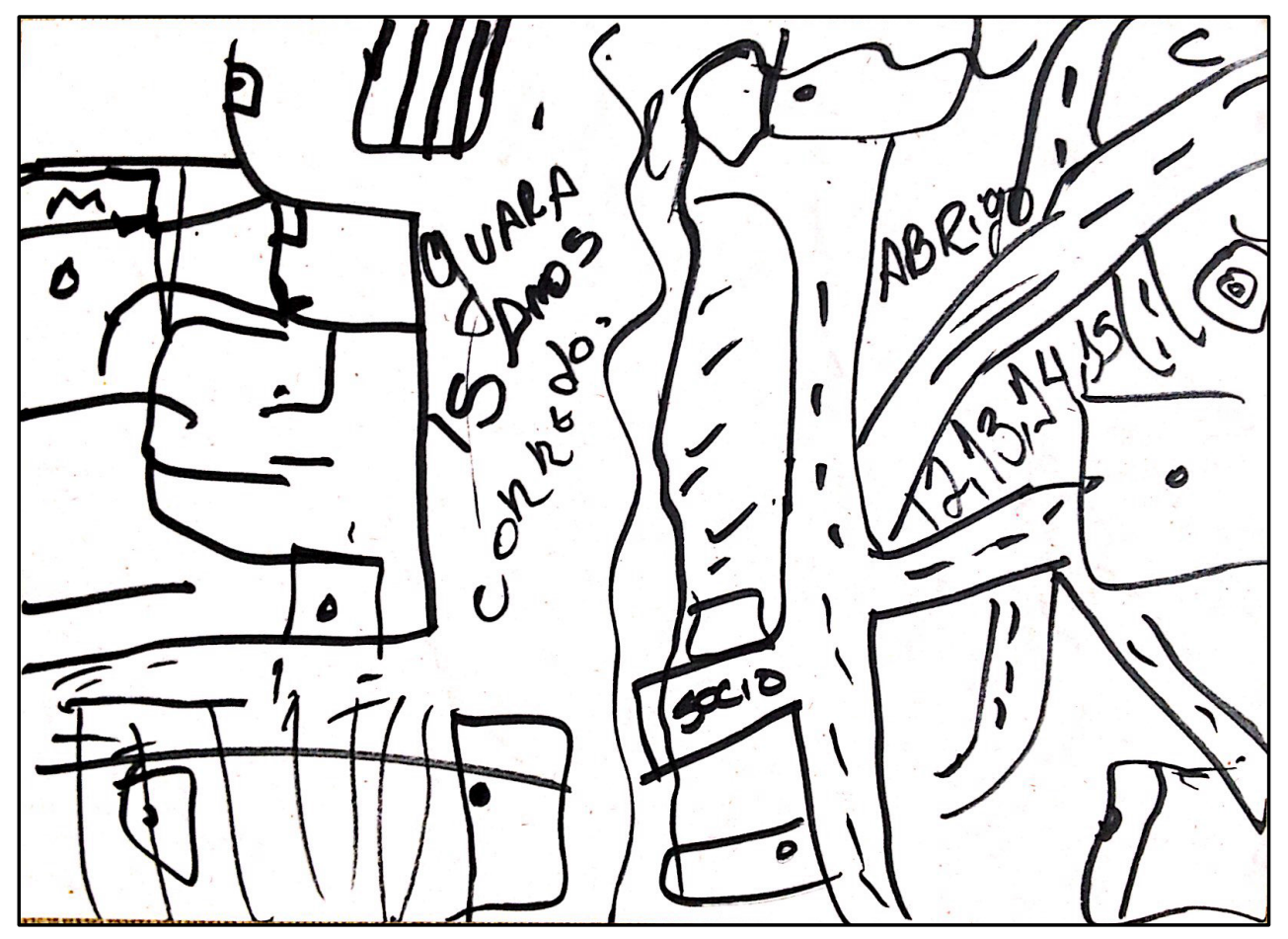

Figura 31 - Momento 4 
Nesse quarto momento, Simone começou desenhando a Instituição A1 em metade da folha, uma Casa Lar onde ficou depois que saiu da Instituição A aos 15 anos (ela anota a idade), e antes de ir para a Instituição A2, também na modalidade Casa Lar. Ela ilustrou o quarto dos meninos, a porta da frente, o portão da rua, a rua, o portão pequeno, a área de serviço, o corredor, a área dos fundos, a lavanderia, a churrasqueira, o quarto dos cuidadores sociais, a cozinha, a sala, o quarto dos bebês e o quarto das meninas. Desenhou como se fosse a planta baixa de um imóvel, feito por um engenheiro civil e relatou que, quando estava nessa casa, dormia num quarto com outras duas adolescentes.

Na outra metade da folha, a pesquisadora pediu para Simone desenhar a Instituição A. Ela anotou a idade em que ficou no local, dos 12 aos 15 anos, e desenhou, em formato de planta baixa também, como na engenharia civil, a guarita, umas casas abandonadas que ali existiam, a cerca, o local onde ocorriam atividades socioeducativas, a recepção, um local onde aconteciam as brigas entre os acolhidos, uma casa lar e um quiosque. As casas abandonadas dizem respeito a umas casas que ficavam num terreno vizinho ao abrigo institucional e que anos antes, tratavam-se de casas que compunham a instituição e recebiam acolhidos também. No momento da entrevista, existia uma cerca dividindo essas casas abandonadas, que eram em torno de quatro casas, do restante da Unidade. Os acolhidos, então, iam até essas casas para usarem drogas e esconderem objetos oriundos de furtos e roubos.

Assim, na Figura 31, diferente da Figura 29, os caminhos são colocados entre os quadrados, indicando um aumento da possibilidade de Simone em transitar entre os espaços. Pode-se indicar que o trabalho com histórias de vida por meio do desenho, auxilia o adolescente a criar possibilidades frente à sua trajetória.

Quando Simone apresentou esses dois locais de acolhimento institucional, ela se preocupou em desenhar somente os espaços físicos, indicando certa impessoalidade na instituição. Talvez isso ocorreu pelo comando da pesquisadora, que solicitou que ela 
desenhasse os dois espaços de acolhimento. Mas, conforme se observou no desenho a seguir, quando Simone comparou a instituição de acolhimento com a rua, pode-se observar novos elementos.

\subsubsection{Momento 5}

A pesquisadora pediu então para Simone desenhar algo para comparar a instituição de acolhimento com a rua, ao que ela desenhou uma casa da Instituição A com quarto dos meninos, quarto das meninas, quarto do cuidador social, banheiro feminino, banheiro masculino, sala com sofá, televisão e uma porta grande, cozinha e área externa. Novamente, Simone desenhou como uma planta baixa e anotou a idade em que chegou no local, ou seja, 12 anos.

Sobre a rua, desenhou na outra metade da folha, à direita e escreveu a idade de 13 anos. Desenhou uma rua, uma ponte, água, uma casinha e drogas. Como exemplo, falou do crack, mas reforçou que nunca fez uso dessa droga, por isso, não era necessário desenhá-la. Continuou desenhando um homem pedindo dinheiro para comprar droga, levantando a mão, um traficante conversando com outro e entregando droga, além de uns colchões. Simone disse que dormia no colchão, e continuou desenhando uma pessoa portanto uma arma. Ao final do desenho disse que desenhar era melhor do que falar, indicando a importância do desenho como meio de facilitar que o adolescente expresse sua história de vida ou qualquer situação vivenciada. Além do mais, comparando-se os tipos de desenhos de Simone, percebe-se que o ato de desenhar possui um valor reflexivo, na medida em que evidencia-se uma progressão na forma dela se expressar graficamente: de quadrados que não se comunicavam entre si à representação de quadrados que não só se ligam por caminhos, como passam a ideia de movimento, com a presença de um carro na Figura 32. 
Mas comparando-se a instituição de acolhimento e a rua, observa-se claramente que essa instituição é impessoal, pois ao representar a rua, Simone incluiu pessoas, nas mais diversas atividades, e o local onde dormia. Assim, por mais que o acolhimento tenha esse nome, para a adolescente em questão, a rua era um local mais acolhedor. Em outras palavras, como afirmou em entrevista, muitos acolhidos preferiam ficar na rua pela tristeza das instituições.

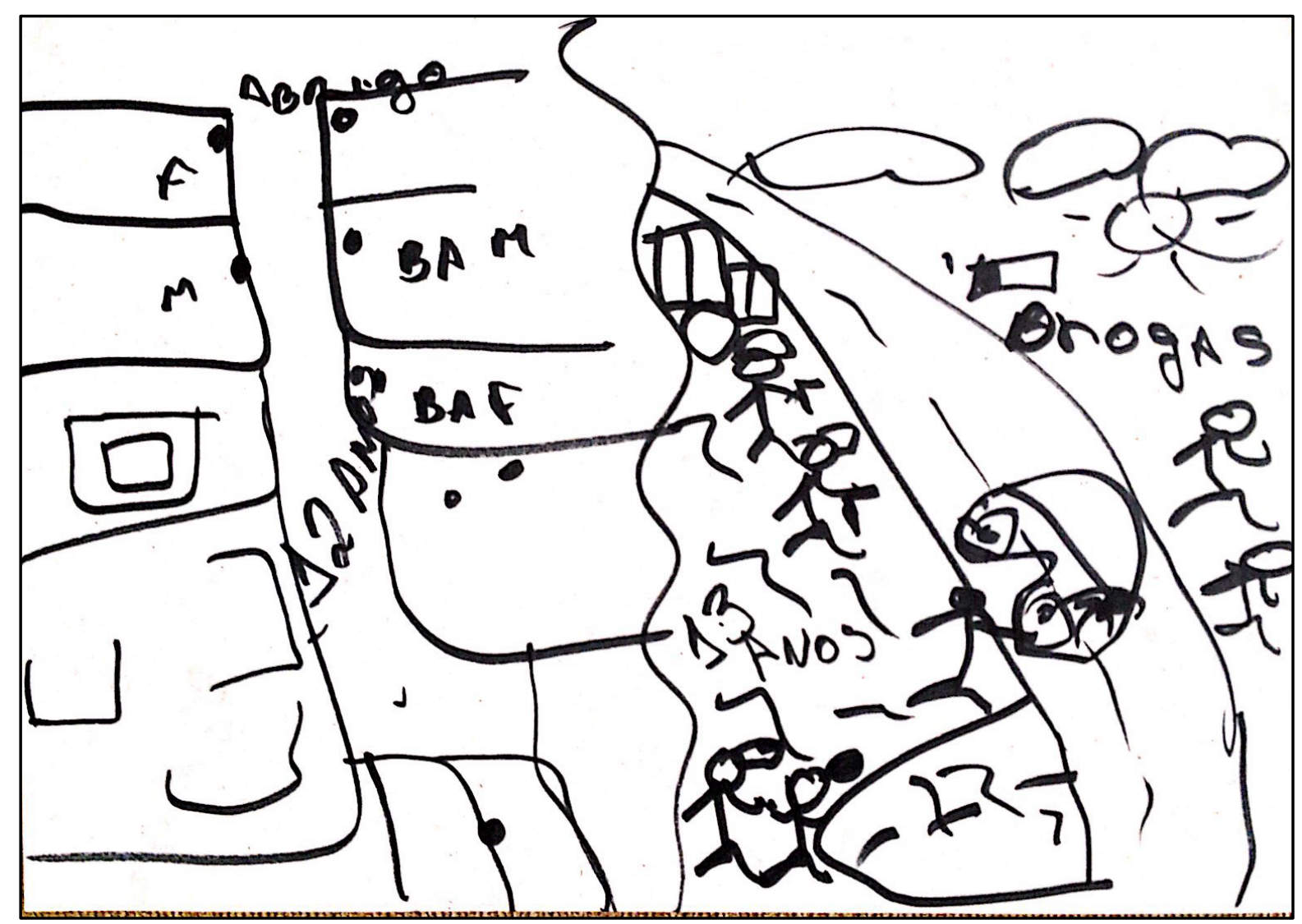

Figura 32 - Momento 5

\subsubsection{Momento 6}

A pesquisadora pediu para Simone desenhar como era o local onde estava naquele momento, aos 16 anos, que era a Instituição A2. Ela ilustrou a casa com um portão, a rua, a casa do vizinho, a calçada, uma área da casa, o corredor, a porta da casa, a sala, a cozinha, a 
parte dos fundos da casa, a lavanderia e o quarto dos meninos. Todos os desenhos elaborados por Simone sobre a instituição de acolhimento foram impessoais, indicando a dificuldade dela em permanecer muito tempo nesse espaço, precisando revezar com momentos na rua. Ao mesmo tempo, esse desenho se apresenta de forma mais organizada, mais estruturado, indicando novamente que o uso de desenhos para expressão de histórias de vida possibilita certa organização dessas vivências.

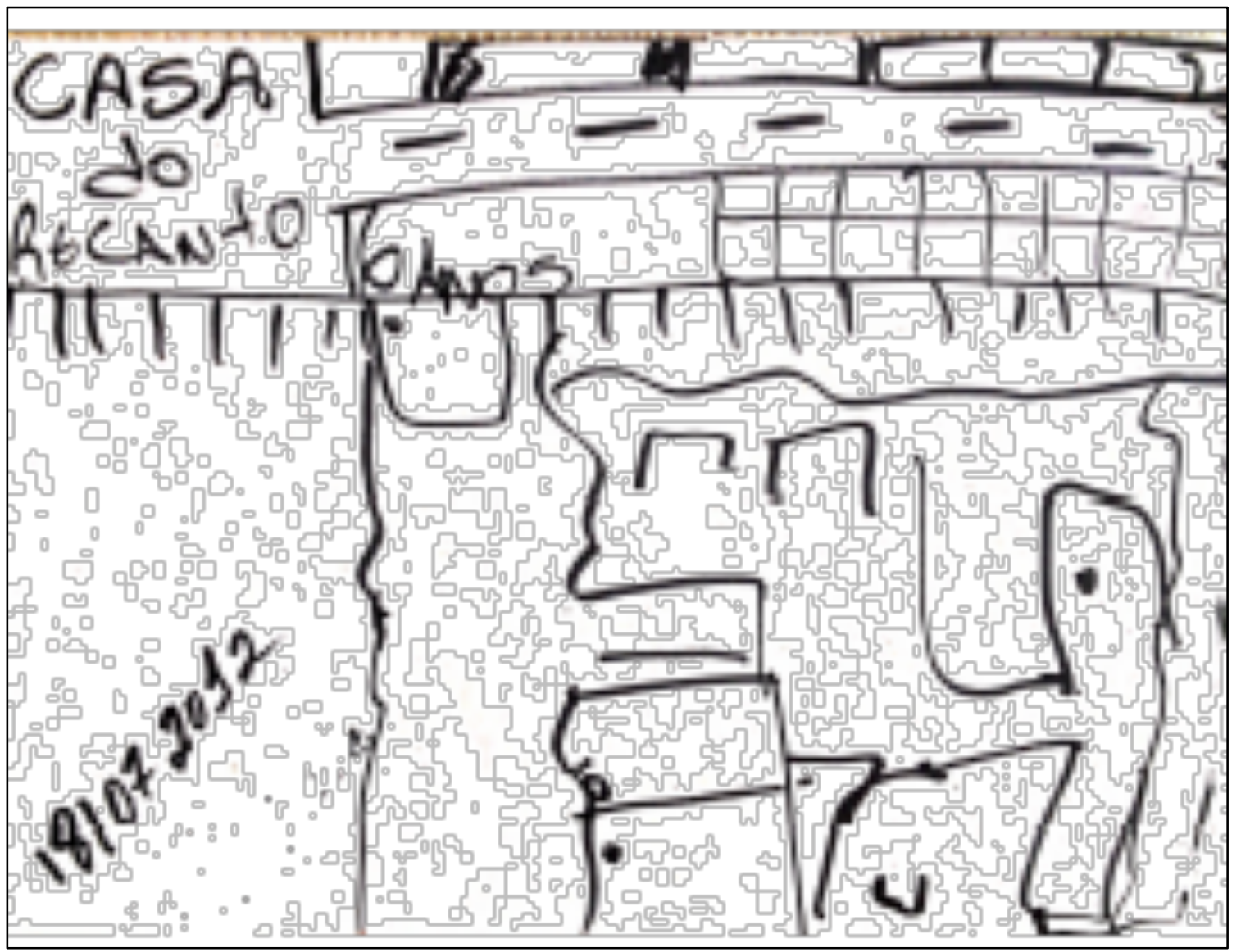

Figura 33 - Momento 6 


\subsubsection{Momento 7}

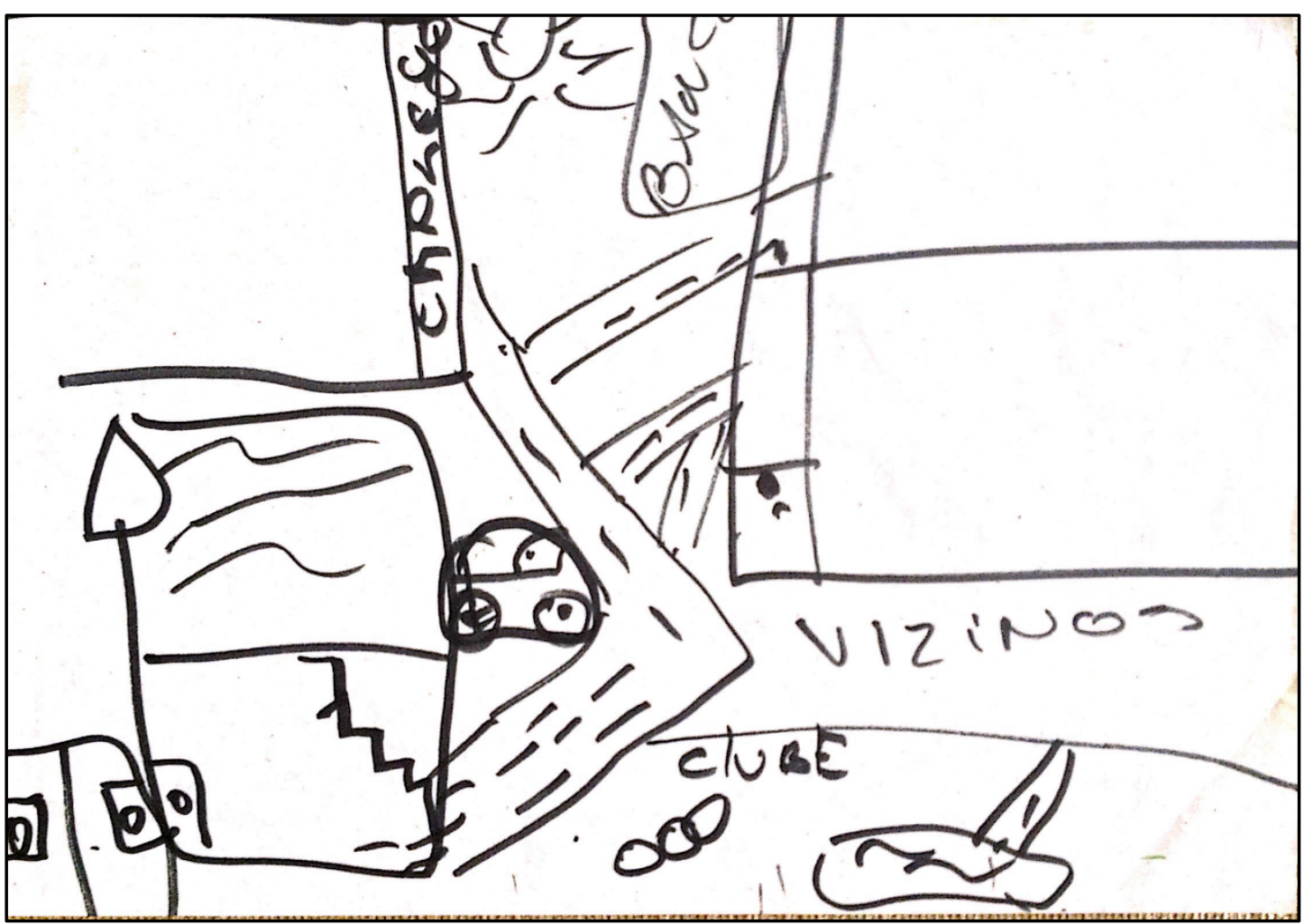

Figura 34 - Momento 7

Sobre o futuro, Simone disse que gostaria de ter um carro, dinheiro e um emprego. Então, ela desenhou o local do emprego, mas não disse qual seria esse emprego, uma estrada da frente, sua casa com dois andares, um carro (um fusca) e um campo para se jogar futebol atrás da sua casa. Esse era o esporte que Simone mais gostava. Disse também que vai ter vizinhos "legais", um clube com piscina em frente a sua casa e um banco, perto de sua casa, para sacar dinheiro quando precisasse.

Simone conseguiu organizar melhor como será seu futuro por meio do desenho e, por mais que tivesse dito anteriormente que gostaria de ser policial federal para ficar com drogas apreendidas, o tema droga não apareceu no momento em que organizou essa ilustração. Talvez, pode-se indicar que o trabalho com adolescentes por meio da criação gráfica possa auxiliá-los a refletir sobre suas possibilidades e sonhar com alternativas que, no cotidiano de vivências violentas que requerem soluções imediatas, não são possíveis. 


\subsubsection{Momento 8}

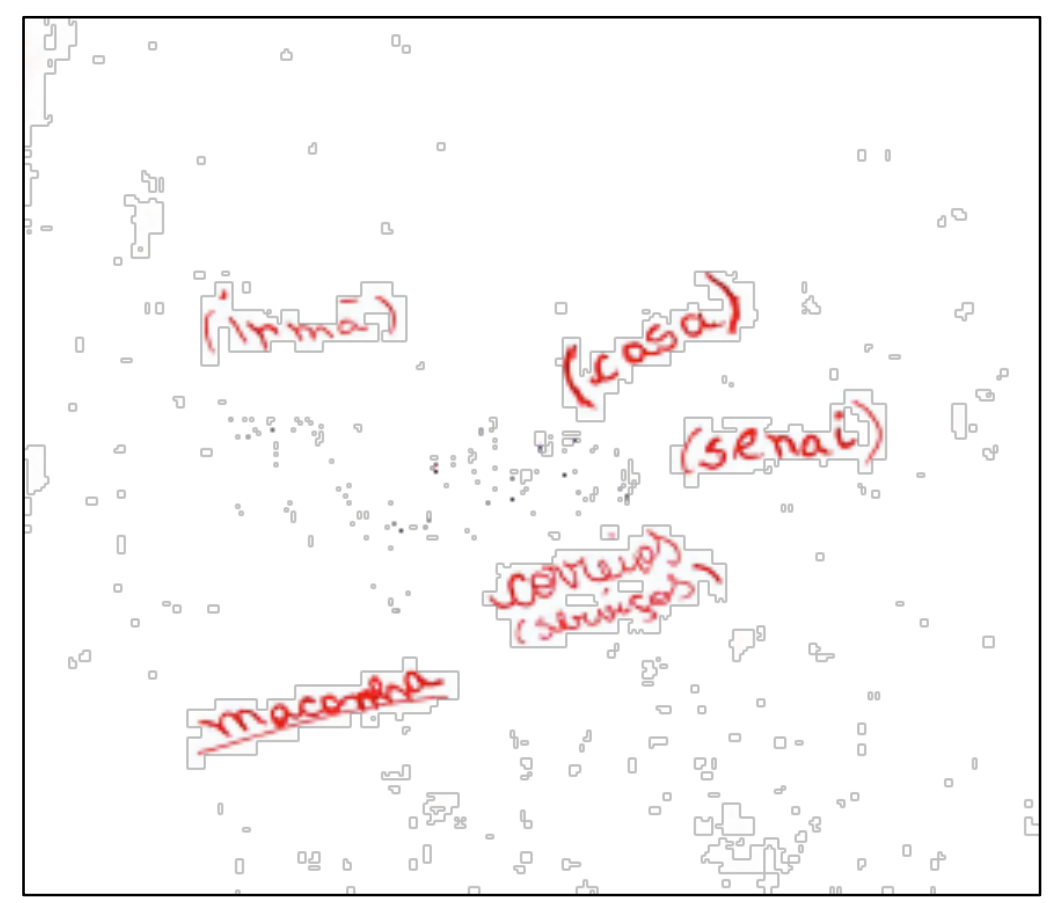

Figura 35 - Momento 8

Simone representou por meio da Figura 35, sua rede de apoio psicossocial, a pedido da pesquisadora. Ela escreveu seu nome no centro da folha, conforme sugestão da pesquisadora, depois acrescentou as demais informações. O primeiro componente da rede foi o estágio onde estava, pois eles pagavam para ela fazer um curso profissionalizante e também, por conseguir receber algum dinheiro com ele. O trabalho ajudava Simone, segundo ela, a diminuir o uso de drogas. Em seguida, escreveu o nome do local onde fazia o curso profissionalizante de auxiliar administrativo, que também a ajudava a diminuir o uso de drogas.

Como terceiro componente da rede, Simone escreveu "casa", dizendo que era a Unidade de Acolhimento onde estava no momento da última entrevista (Instituição B). Acrescentou que na verdade não podia contar muito com a ajuda dos profissionais do local, mas ao mesmo tempo, era bom porque tinha comida e um lugar para dormir. Estava nessa instituição, pois estava esperando juntar um pouco de dinheiro, a partir do que recebia no trabalho, para alugar 
uma moradia e se mudar de lá. Mas ressaltou que ainda não havia economizado qualquer quantia para tal.

O quarto item da rede de apoio foi a irmã. Segundo Simone, ela não precisava dela, no sentido financeiro, mas o importante era manter uma vinculação afetiva com ela. Quando precisava falar com alguém, recorria à irmã. Na realidade, era sua irmã que precisava de Simone. O lado positivo de visitar a irmã estava relacionado ao fato de Simone sentir-se em casa, não em uma instituição. Lá ela usava maconha, levava a sobrinha para passear e ia à casa das pessoas que não via há tempos, como se estivesse de férias.

Como quinto item, Simone falou da maconha, dizendo que essa droga a ajudava em tudo. Ela não conseguia entrar no local do curso se não tivesse sob efeito de maconha. Nesse lugar, havia muito "nerd", referindo-se a pessoas que estudavam muito e que sempre seguiam as regras do local. Também era o lugar mais difícil de ficar, já que estava aprendendo coisas que nunca havia visto antes, como logística e comunicação. As matérias eram legais, como qualificou Simone, mas se ela faltava um dia, perdia muito conteúdo que havia sido ministrado. A droga também a ajudava a permanecer na instituição de acolhimento. Vale ressaltar que o papel da droga, principalmente da maconha, que sempre esteve presente na trajetória de Simone durante as entrevistas, fica mais claro nessa ilustração, aparecendo como apoio para que ela em tudo o que fazia. Esse ponto confirma o porque das tentativas dos profissionais da instituição de acolhimento em afastá-la de grupos que faziam uso de droga fracassaram.

Simone não colocou mais ninguém em sua rede de apoio, pois disse que as pessoas eram falsas e não podia contar com elas, não podia confiar totalmente em alguém. A irmã estava parcialmente disponível para quando ela precisasse, mas, ao mesmo tempo, não pôde contar com seu apoio em alguns momentos. Então, ela ficava confusa se podia ou não confiar nela. 
Percebe-se que, com exceção da irmã e da maconha, os outros pontos de apoio de Simone referiam-se a instituições às quais estava vinculada no momento da entrevista (local do acolhimento, do trabalho e do curso). Então, tirando os vínculos estabelecidos com instituições temporariamente e a irmã, com quem somente podia contar em alguns momentos, a maconha era o único apoio que Simone pôde ter nos seus vários momentos de vida, mediando sua relação com o mundo.

\subsubsection{Momento 9}

No último desenho, Simone representou o mundo e seu lugar nele, a pedido da pesquisadora. Nessa representação, se qualificou como normal, nem pobre nem rica. Ela dividiu o mundo em três partes que continham pessoas normais, como ela, duas partes para pessoas ricas, duas partes para pessoas pobres, duas partes com pessoas as quais denominou médias, uma parte com pessoas muito ricas e uma parte contendo pessoas muito pobres. Para ela, as pessoas médias são aquelas que encontram-se estabilizadas na vida, pois têm onde morar e trabalhar. Os médios estariam um pouco melhores que os normais. Segundo Léonetti (2007a), entre os pólos de integração e exclusão social, existe um processo no qual cada pessoa se insere na sociedade onde vive de diversas maneiras. E ao menos três dimensões podem ser identificadas: econômica (participação social por meio do trabalho e do consumo), social (pertencimento a grupos primários e estabelecimento de relações sociais institucionais) e simbólica (normas e valores compartilhados, além de representações coletivas sobre lugares sociais). Assim, a partir do desenho a seguir, percebe-se que Simone organiza e divide o mundo a partir do viés econômico, classificando os grupos a partir da riqueza de cada um. 


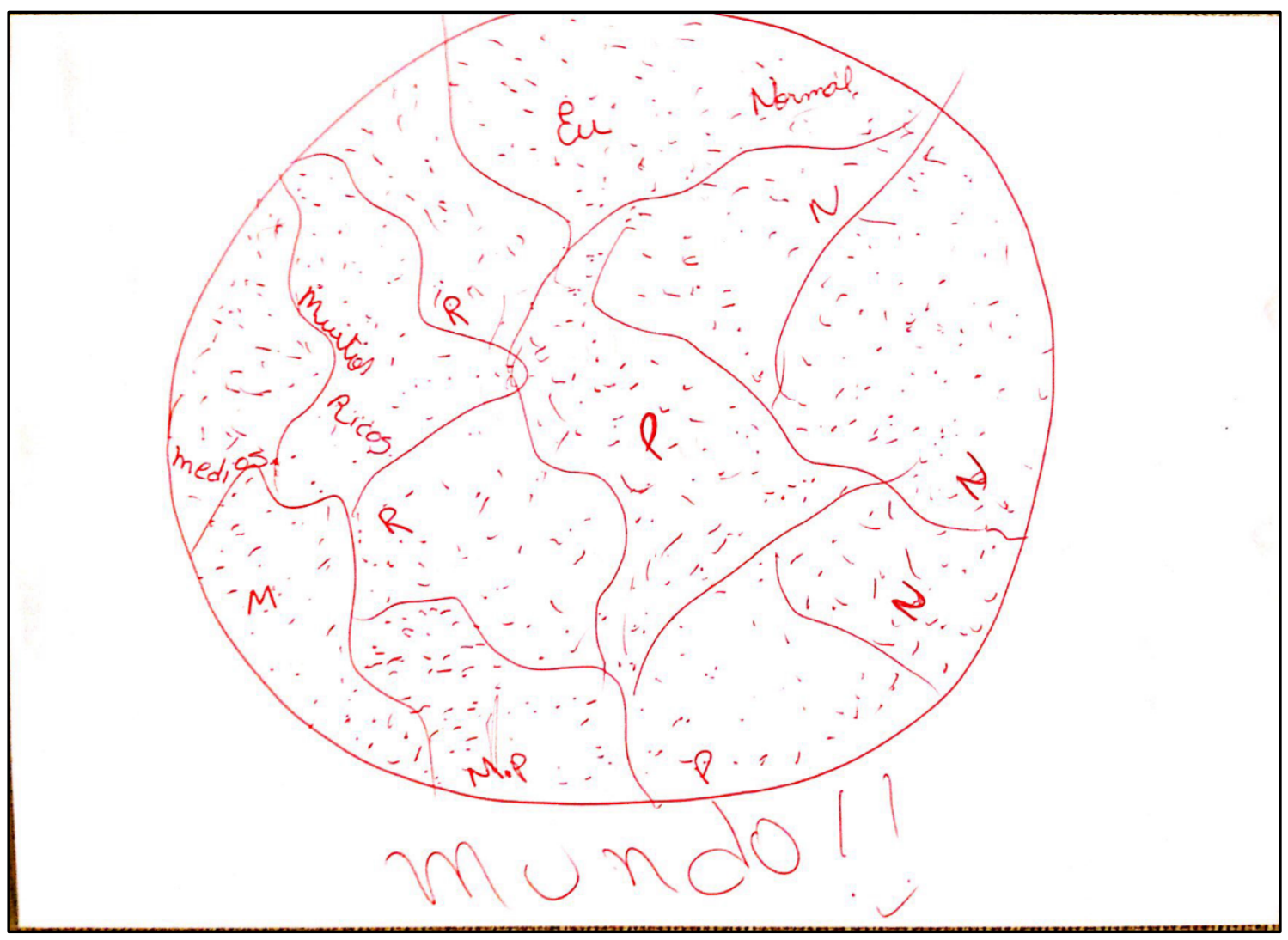

Figura 36 - Momento 9

Para Simone, ela não se encontrava excluída do mundo, da sociedade, mas fazia parte dele. Além do mais, classificou-se como uma pessoa normal, como as que estão presentes na maioria das partes do mundo (em três partes, ao contrário dos outros grupos sociais que estão, segundo ela, em duas partes ou em uma). Como os desenhos iniciais de Simone, quando representou alguns quadrados sem comunicação, ela indicou que entre os grupos sociais, indicados na Figura 36, não há caminho ou ligação entre esses grupos. Em outras palavras, não há possibilidade de uma pessoa sair de um grupo e fazer parte de outro grupo social, por mais que todos formem um conjunto só. Simone indica um ponto importante: estar incluído na sociedade não significa ter acesso ao que as demais pessoas teriam. Nesse sentido, sugerese que o significado para os profissionais da instituição de acolhimento da exclusão e da reintegração social de adolescentes acolhidos precisa ser reavaliado e aproximado do significado que esses adolescentes possuem desses conceitos. Pode ocorrer que, pelo 
distanciamento entre a compreensão de algo que, aparentemente já está pronto, para os profissionais, em relação à percepção do adolescente, as ações não obtém o resultado esperado pelos profissionais. Construir uma projeto de vida junto ao adolescente para que ele seja inserido na sociedade pode não fazer sentido para o acolhido, se ele já se perceber como integrante dessa sociedade, mesmo que ocupando um lugar que desafia as regras e normas estabelecidas. 


\section{SABER PROFISSIONAL - ALICE: RESSONÂNCIAS DAS HISTÓRIAS DE VIDA DE ADOLESCENTES ACOLHIDOS}

Alice foi a terceira participante deste estudo. Ela era assistente social da Instituição A, na qual tanto Marcos quanto Simone haviam sido acolhidos. O foco da narrativa da mesma foi em sua trajetória profissional, iniciando na sua formação acadêmica e passando pelos locais onde trabalhou. $\mathrm{O}$ acesso à trajetória de Alice deu-se em uma única entrevista com a pesquisadora.

\subsection{NÍVEL DESCRITIVO-CRONOLÓGICA}

\subsubsection{Formação profissional}

Alice, quando estava no Ensino Médio, passou por processo de psicoterapia e nessa época, pensou em cursar Psicologia na graduação. Mas a psicóloga que a acompanhava sugeriu que ela buscasse informações sobre o curso de Serviço Social, o qual Alice nunca havia ouvido falar. Ela gostou e escolheu, no vestibular, Psicologia como primeira opção e Serviço Social como segunda. Alice foi aprovada na segunda opção, cursando Serviço Social em uma universidade da Região Sudeste do Brasil.

A cidade natal de Alice tinha, à época, 40 mil habitantes e ficava no interior do Estado. Assim, durante os dois primeiros anos de estudo na universidade, Alice ia para a Universidade e voltada diariamente para sua cidade de origem, que ficava a $30 \mathrm{Km}$ de distância. Já no terceiro ano de Universidade, se mudou para a cidade onde estudava.

Ao sair de uma cidade pequena e se mudar para uma cidade grande, Alice ficou deslumbrada com essa nova experiência, com os novos lugares que conheceu, novas pessoas, e não aproveitou totalmente sua formação em Serviço Social. Mas, ao mesmo tempo, fez estágio desde o segundo semestre da graduação. Começou em sua cidade natal, em um centro 
de referência para adolescentes autores de ato infracional, que estavam em liberdade assistida ou prestando serviço à comunidade, onde permaneceu durante um ano. Trabalhar com adolescentes sempre foi a preferência de Alice.

Também fez estágio na área de saúde, em um ambulatório, onde acompanhava pessoas com hipertensão, diabetes, gestantes, que faziam uso de medicamento de alto custo, além do trabalho de planejamento familiar. Nessa época, se mudou para a cidade, já que o estágio era remunerado e ela poderia se manter no novo local de moradia. Outro local onde atuou como estagiária com mediação de conflitos, por três meses, foi em uma delegacia da mulher. A fim de aumentar sua renda, também trabalhou em um call center durante a universidade.

\subsubsection{Primeira experiência em unidade de acolhimento}

Seu contato com acolhimento de adolescentes começou por meio de outro estágio, em 2003, onde trabalhou em uma instituição, do tipo casa de passagem, para adolescentes em situação de rua. Era um local que, apesar de público, havia uma limitação de 12 vagas, sendo essa sua capacidade máxima de acolhimento. Os adolescentes que não estavam em situação de rua e precisavam de acolhimento, iam para outra instituição. Alice ficou no local por um ano como estagiária e, depois, mais três meses como voluntária, em 2005, sendo esse último período, após a conclusão de sua formação em Serviço Social. Na cidade não existia muita opção de concurso público para trabalho, o que a levou a ficar esse tempo como voluntária, enquanto não conseguia um emprego.

Mas trabalhar nessa instituição de acolhimento foi algo que Alice gostou bastante, pela proposta, pela atuação da equipe e pela forma de trabalho em geral, o que a motivou a escolher trabalhar no mesmo tipo de instituição, tempos depois. Nessa unidade de acolhimento, os adolescentes, após chegarem, tinham 24 horas para refletir se aceitavam ou não aquela ajuda e continuarem acolhidos. 
Para esse momento inicial, eles ficavam em um quarto separado dos demais, onde havia objetos pedagógicos, sem participarem da rotina da unidade e prejudicarem o andamento do cotidiano da casa. Os adolescentes não eram obrigados a ficar lá, podiam sair desse quarto quando quisessem, caso não aceitassem o acolhimento. Os reincidentes, que já tinham sido acolhidos no local, tinham o tempo reduzido de 12 horas para fazer essa reflexão, nesse quarto. Esse período também funcionava como um início do processo de desintoxicação das drogas.

Após a aceitação do adolescente quanto ao próprio acolhimento, sua roupa e demais pertences eram recolhidos e guardados para, a partir de então, utilizar somente as roupas que a instituição fornecia, que eram de doação. No momento em que o acolhido fosse reintegrado à sua família ou fosse embora do local por qualquer outro motivo, seus pertences eram devolvidos.

Durante o primeiro mês, eles ficavam na instituição de acolhimento e uma pedagoga trabalhava com eles as questões da escola, para conhecer até onde ia o conhecimento escolar deles, como por exemplo, para saber se sabiam ler e escrever. Muitos não eram alfabetizados. Era uma forma também de estimulá-los a voltar para a escola. Após esse período, eles eram matriculados e iam para a escola acompanhados por um cuidador social, que ficava em sala de aula ou fora, dependendo do caso. Para isso, o número de cuidadores que trabalhavam de dia era bem maior que o da noite, a fim de favorecer esse acompanhamento bem próximo dos acolhidos.

O fato dos adolescentes escolherem estarem acolhidos e aceitarem as regras e a rotina da unidade logo no início, facilitava bastante o trabalho dos profissionais. Na instituição havia algumas oficinas, como as de fuxico, macramê e pintura de pano de prato. E após dois ou três meses frequentando a escola, os adolescentes eram inseridos em cursos da comunidade, como balé e informática. A instituição ficava em um imóvel de dois andares, e havia um segurança 
patrimonial na porta, que ficava geralmente do lado de fora e não tinha muito contato com os acolhidos. Sobre as refeições, essa era preparada pela cuidadora social, com o auxílio dos adolescentes. Existia uma mesa grande onde todos comiam, acolhidos e funcionários, juntos. O que era disponibilizado para um, era também para outro, sem distinção entre adolescentes e profissionais. De forma geral, existia uma escala onde os adolescentes sempre cuidavam da casa, com o auxílio do cuidador.

Mas era comum alguns adolescentes apresentarem algum tipo de recaída e voltarem para a rua. Porém, ao retornarem para a instituição, eles estavam um pouco melhor, o que levava a equipe profissional a considerar que não era possível um resgate de um dia para o outro e que uma mudança maior junto ao acolhido, era algo possível mas que demandava um tempo considerável. Era comum os adolescentes ficarem nesse movimento de ir e voltar, entre a rua e a instituição, por dois ou três anos. Quando saíam da instituição, eles iam para locais já conhecidos por eles e que ficavam próximos, como uma praça próxima da rodoviária da cidade, ou uma estação de trem desativada. Nesses locais, eles iam fazer uso de crack, cola de sapateiro e tinner.

Mais diretamente sobre a atuação de Alice, enquanto atuou como estagiária, teve pouco contato com sua supervisora de campo, pois essa engravidou e foi afastada do trabalho. A supervisão ocorreu ocasionalmente e à distância. Então, ela era a única pessoa relacionada ao serviço social na instituição, tendo tido muita dificuldade no início, quando precisou aprender muita coisa sozinha ou com a ajuda de outros profissionais da unidade. Havia uma gerente que a ajudava, mas somente a cada 15 dias. Depois de quase todo seu período como estagiária, que foi de um ano, contrataram uma assistente social para trabalhar com ela na Unidade. Mas Alice, mesmo como voluntária, após três meses de trabalho, foi impedida de continuar a atuar na instituição. Isso ocorreu por causa da mudança de governo e de partido 
político na gestão e com isso, muitos foram substituídos por novos profissionais, de confiança da nova equipe.

A partir dessa experiência, Alice aprendeu que para uma mudança na vida de alguém, essa pessoa precisa ter motivação para essa mudança e que isso demanda tempo. Isso faz o trabalho na área social ser frustrante, já que o resultado aparece a longo prazo. Os profissionais precisam gostar e acreditar muito no que fazem. Precisam também considerar todos os elementos que atuam na história do adolescente, observando e focando no que pode favorecer uma mudança, no sentido de encaminhar sua vida para melhor.

Alice se identifica com os adolescentes, pois considera que sua adolescência foi rebelde. Deu muito trabalho à sua família e não se sentia compreendida à época. Com isso, enquanto profissional, se esforça para compreender os adolescentes com os quais trabalha, entender os motivos que os levaram a fazer certas escolhas, como morar na rua, usar droga e preferir um amigo à própria família.

\subsubsection{Trabalho com adolescentes autores de ato infracional em instituição privada}

O companheiro de Alice à época, recebeu um convite para trabalhar em Brasília, depois que ela saiu do trabalho voluntário. Então, casaram-se e se mudaram para a capital do país. Após um mês de casamento, Alice engravidou de sua filha e depois que ela nasceu, passado um tempo, resolveu colocá-la na escola e entregar currículo, procurando emprego. Foi contratada para atuar em uma unidade de internação provisória para adolescentes do sexo masculino, autores de ato infracional no início de 2008, onde trabalhou durante um ano. Se apaixonou pelo seu novo local de trabalho.

Uma das coisas que lhe chamou a atenção foi o Projeto Pedagógico dessa instituição e percebe hoje, que a metodologia de trabalho utilizada por eles é essencial no trabalho com adolescentes. Outro fator importante e essencial era o comprometimento da equipe 
profissional com seu trabalho. A instituição funcionava como um sistema, onde todas as peças se encaixavam e funcionavam ao mesmo tempo e que, vista de longe, percebia-se algo muito bonito. Mas para isso, o trabalho era cansativo e desgastante, pois os profissionais eram pressionados a "funcionar" realmente.

Esse tipo de organização era totalmente diferente do serviço público, pois a exigência em termos de qualidade do trabalho era maior, o que favorecia maior comprometimento dos profissionais que seguiam a metodologia proposta. É um local cuja gestão era de responsabilidade de um grupo de padres, mas que primavam por seguir o que estava disposto no SINASE (Sistema Nacional de Atendimento Socioeducativo). Por exemplo: eles seguiam à risca o número máximo recomendado de adolescentes por quarto.

Os adolescentes eram organizados em turmas com 10 ou 12 meninos, que eram acompanhadas por educadores. A cada duas turmas, havia uma equipe técnica responsável, composta por um assistente social, um psicólogo e um coordenador. Uma das turmas era exclusiva para meninos que não podiam entrar em contato com os demais por motivos diversos: ameaça, orientação sexual diversa da maioria e situação de rua. Os que precisavam sofrer algum tipo de sanção também ficavam um tempo separados dos demais, para refletir sobre o que fizeram. Cada turma possuía um nome que lhe foi designado tempos atrás, pelos adolescentes da época.

Nessa instituição, a atuação do assistente social era distinto da intervenção do psicólogo, mas complementares. Por exemplo: o psicólogo trabalhava algumas questões em grupo com os adolescentes e o assistente social fazia visita familiar. De forma geral, o comprometimento dos profissionais estava relacionado ao fato de a instituição não ser pública, tendo em vista que podiam ser demitidos caso não trabalhassem de forma adequada. Com isso, se doavam no trabalho, se envolviam e por fim, passavam a gostar do que faziam. Para estar nesse tipo de 
atuação, os profissionais precisam gostar do que fazem, não basta estar no local somente pelo salário.

Outra questão fundamental na instituição onde Alice trabalhava era a supervisão constante da coordenação junto à equipe. Além do mais, todos seguiam os protocolos existentes na rotina da unidade. Se era dia de reunião, todos paravam o que estavam fazendo e compareciam, sempre chegando na hora. Não havia flexibilidade para não comparecer ou chegar depois. E em relação à postura do funcionário, ninguém falava mais alto que o chefe.

No geral, a organização da instituição, a rotina, os protocolos que eram seguidos, o projeto pedagógico, a exigência de comprometimento dos funcionários e qualidade no serviço e a postura de todos, faziam a diferença e favoreciam o bom andamento do trabalho. O setor administrativo era bem organizado e o padre, responsável pela instituição, sempre estava presente e monitorava o trabalho. É o que Alice acredita que deveria acontecer em qualquer local de trabalho.

O padre se preocupava com os profissionais e se algum não estava bem, ele se aproximava e perguntava o que estava ocorrendo, buscando sempre ajudar essa pessoa. Mas também se o rendimento de alguém estava caindo, ele se aproximava para ver o que estava acontecendo e buscava alternativas para melhorar o desempenho do funcionário.

Nesse meio tempo, Alice concorreu a vaga de assistente social em um concurso público, mas pensava que não iria ser aprovada, pois a concorrência era grande. Ela percebeu uma diferença entre Brasília e a cidade onde morava anteriormente, porque na capital federal, existia uma cobrança para se trabalhar no serviço público. Onde morava, o mais importante era arrumar um trabalho, seja ele em instituição pública ou privada.

No local de trabalho, a psicóloga que trabalhava de dupla com Alice, estudava muito para ser aprovada em concurso público, até no horário de almoço. Então, influenciada por essa pressão de ser uma servidora pública, Alice começou a ler alguns textos que iriam ser 
cobrados na prova. Depois, com colegas, foram conferir o gabarito da prova e, dentre os 15 profissionais daquela instituição que concorreram, somente Alice e outra assistente social foram selecionadas. Alice vinha do interior de São Paulo e havia sido aprovada, ao que uma colega comentou que não acreditava que ela, que não falava "o português direito", havia sido aprovada, referindo-se às gírias da cidade do interior que Alice utilizava. As pessoas fizeram uma festa quando viram que ela tinha sido aprovada, e ela também ficou feliz, mas não compreendia o tamanho da felicidade de todo mundo. Deixou essa instituição com uma "dor no coração", pois amava seu trabalho.

\subsubsection{Trabalho em uma Instituição de Acolhimento}

Na primeira reunião no novo local de trabalho, em 2009, a pauta era a definição da unidade onde os novos funcionários iriam trabalhar. Alice já sabia que iria escolher uma instituição de acolhimento. Na época existiam duas, uma que acolhia crianças e adolescentes e outro que recebia adolescentes e jovens em situação de rua. Ela escolheu a primeira, por ficar mais próximo de sua residência.

Com Alice, foram mais 14 especialistas, sendo psicólogos, assistentes sociais e uma pedagoga, mas muitos psicólogos não conheciam o trabalho da assistência social, inclusive, nunca tinham ouvido falar em Conselho Tutelar. Ela já foi sabendo o que ia encontrar, mas muitos foram porque não tinham outra opção de escolha quanto ao local de trabalho.

Ao chegar na instituição de acolhimento, Alice sofreu muito no primeiro ano pois as características de organização do trabalho anterior, como o movimento das coisas se encaixarem, funcionarem e fluírem não se faziam presentes na nova unidade. Uma vez pediu para voltar a trabalhar na instituição antiga, mas por fim, permaneceu onde estava. No serviço público, a estabilidade do trabalhador o afasta do compromisso com o trabalho. Outra questão 
era que o trabalho do psicólogo e do assistente social não eram diferenciados, os dois atuavam praticamente da mesma forma.

Alice e os novos especialistas não passavam por nenhum tipo de ambientação ou capacitação quanto ao novo local de trabalho, que recebia crianças e adolescentes de zero a 17 anos e 11 meses. Os funcionários que já estavam lá há mais tempo é que mostraram a eles como a instituição funcionava e o que deveriam fazer. O não conhecimento do trabalho pela maioria dos novos especialistas dificultou a atuação inicial da equipe na unidade. Quanto aos cuidadores sociais, esses estavam lá por um contrato temporário que havia, não tinham sido aprovados em concurso público.

Desde 2006, a instituição passava por um processo de descentralização das casas e, quando Alice ali chegou, havia cinco casas dentro de um grande terreno. As duas únicas assistentes sociais, que já trabalhavam há tempos na instituição, receberam os novos profissionais concursados muito bem, já que precisavam aumentar a equipe para trabalharem melhor. As duas fizeram uma festa para recebê-los. Não havia coordenação à época, mas um tempo depois, receberam uma nova coordenadora e duas assistentes da coordenação. Uma delas, fazia um trabalho de Terapia Comunitária junto aos profissionais, o que era bem interessante.

Já o setor administrativo não agia com muita autonomia, pois existia uma equipe administrativa central que cuidava de outras unidades existentes na cidade, sendo de acolhimento ou não, mas todas de cunho socioassistencial. Assim, essa equipe central não visitava com frequência a Unidade onde Alice trabalhava. Existia também uma equipe externa à unidade que acompanhava todas as unidades de acolhimento e que deveria fazer supervisão a cada 15 dias, pelo menos, mas que por diversos motivos, também não comparecia com muita frequência. 
Após alguns meses, a coordenação da instituição de acolhimento mudou novamente. Todos os cuidadores sociais contratados temporariamente também saíram, sendo substituídos por cuidadores concursados. Alice percebia que a atuação dos cuidadores contratados era mais eficiente do que os novos cuidadores concursados, apesar de não terem tido boas condições de trabalho. A estrutura física das casas não era adequada, havia insetos, muitas crianças com escabiose (um tipo de doença de pele, conhecida popularmente por sarna) e adolescentes que faziam muito uso de drogas junto com os que não faziam. Inclusive, houve indícios e casos de tentativa de abuso sexual de adolescentes em relação às crianças. Assim, os cuidadores mais antigos tinham maior disposição, comprometimento e identificação com o serviço para lidar com essas situações. Já os novos eram mais jovens, alguns com 18 ou 19 anos e muitos não estavam ali porque queriam ser cuidadores sociais, mas porque aguardavam ser aprovados em outro concurso público.

Era muito difícil, pois nessa época muitos funcionários não cumpriam suas atribuições, boicotando o trabalho. Uns saíam para uma consulta médica particular e não voltavam a trabalhar naquele dia, outros podiam acompanhar algum menino ao médico, mas diziam que era papel do outro e ficavam lendo revista no horário do trabalho. Privilegiava-se o direito do servidor público, mas muitas vezes, era esquecido de se cobrar com que atuasse de maneira eficaz. E o servidor fazia somente o que estava previsto em alguma legislação, somente o que estava escrito. Do contrário, ele não atuava. Com isso, o funcionamento da instituição ficava prejudicado e os funcionários, em sua maioria, se esqueciam de atuar realmente. E o coordenador, por mais que tivesse boas intenções, tinha dificuldades na gestão porque o sistema todo era falho e não contribuía para as coisas funcionarem.

Os especialistas trabalhavam em duplas, geralmente um psicólogo e um assistente social. Mas não era considerada a afinidade entre as pessoas para se formar essas duplas e era difícil trabalhar com quem não se tinha afinidade, com quem não seguia o mesmo raciocínio ou 
tinha o mesmo foco. Mas depois de um tempo, com o amadurecimento da equipe, as duplas foram refeitas para facilitar o trabalho de todos. Era um trabalho difícil, pois as casas estavam lotadas de crianças e adolescentes, o local estava caótico e havia, inclusive, ratos e baratas nas casas. Esse contexto era "surreal" em um local que, por estar na capital do país, deveria ser exemplo para as outras cidades.

Com a segunda coordenação, algumas coisas foram impostas e muitos funcionários sentiram-se assediados moralmente, pois foram obrigados a se adaptarem a um novo plano técnico da instituição. Mas, atualmente, Alice percebe como necessário que a coordenação ou diretoria imponha algumas situações à equipe. Não é possível agradar a todos. O novo plano técnico previa que os especialistas trabalhassem de plantão durante o dia, para que houvesse especialista na unidade de forma ininterrupta, inclusive nos finais de semanas e feriados. Assim, começaram a cumprir uma escala de trabalho de 12 horas seguidas com 36 horas de intervalo (12h X 36h).

Havia muita denúncia nessa época no Ministério Público e na Vara da Infância e da Juventude, sobre as más condições de acolhimento da instituição. Com isso, houve uma intervenção da Vara da Infância e uma equipe do judiciário foi ao local, com uma lista de nomes de algumas crianças, para transferirem a outras unidades de acolhimento da cidade, sem comunicar previamente à instituição. Como há uns dois meses antes dessa intervenção, todos os cuidadores sociais que estavam na unidade foram substituídos por cuidadores concursados, Alice acredita que foram os cuidadores que saíram da Unidade que fizeram a denúncia.

\subsubsection{Reestruturação e projeto político pedagógico}

Desde que Alice começou a trabalhar nessa instituição de acolhimento, ela acompanhava tentativas de elaboração de um projeto pedagógico, de uma metodologia de trabalho, com 
muitas mudanças ocorrendo. Era como trocar o pneu com o carro em movimento. Um dos pontos que Alice colocou para a equipe quando chegou foi a proposta do quarto, que viu onde trabalhou quando fez estágio, onde cada novo acolhido teria um tempo para refletir se aceitava ou não o acolhimento, antes de entrar na rotina da instituição. Na época, ela não foi compreendida, pois pensavam que essa seria uma imposição, uma intervenção do tipo militar. Mas hoje, muitos já concordam que, principalmente o adolescente, precisa anuir estar em acolhimento.

Em dezembro de 2010 houve a descentralização total da unidade, deixando de existir um grande abrigo para ficarem somente casas lares menores, que acolhiam até 10 meninos e meninas. Algumas casas focavam seu atendimento às crianças. No momento da entrevista (segundo semestre de 2013), a equipe de forma geral estava reduzida. Essa redução ocorreu a partir de uma proposta técnica de um grupo de trabalho, do qual Alice participou, pois havia muitos funcionários que não trabalhavam de forma adequada e atrapalhavam o funcionamento geral da instituição. Como uma engrenagem, a atuação de um dependia da atuação de outro.

Um exemplo da inter-relação entre os profissionais: Alice pedia para um funcionário agendar um carro para visita domiciliar para o dia seguinte às 7:00h da manhã e, quando chegava, ou esse funcionário não havia agendado o carro ou o motorista não havia chegado no horário para trabalhar, o que a impedia de realizar a visita. E a cada situação como essa, Alice ficava cada vez mais desmotivada em relação ao trabalho, assim como outros funcionários que também passavam por esse mesmo tipo de situação. Havia também outros funcionários que, por problemas de saúde, trabalhavam com restrição de atividades, como uma telefonista que não podia atender telefone porque tinha uma dificuldade no braço e não podia movimentá-lo com frequência.

Ainda, com a descentralização, o mesmo grupo de trabalho que Alice participou e que decidiu sobre a redução da equipe, decidiu mudar a sede da instituição de local. Tal decisão 
ocorreu, pois havia muitos funcionários mais antigos e que estavam ligados à proposta antiga de trabalho, que valorizava uma grande instituição que acolhia muitas crianças e muitos adolescentes, como os então denominados orfanatos ou internatos. Nesse modelo antigo, os acolhidos participavam de atividades dentro da instituição, já que o foco não era a reintegração familiar e comunitária, e ficavam acolhidos até completarem 18 anos. A visão da época era a do Código de Menores, voltada para o menor infrator e para o assistencialismo. E os funcionários que estavam na Unidade desde o Código de Menores, tinham dificuldades em acompanhar as mudanças a partir do Estatuto da Criança e do Adolescente, com foco na proteção integral do acolhido e na reintegração familiar e comunitária.

A mudança física da sede da Unidade também ocorreu, pois os meninos e meninas haviam criado um vínculo negativo com o local. Alice chamou esse vínculo de negativo, pois os acolhidos gostavam da instituição, não porque a equipe os encaminhavam para a escola, para cursos profissionalizantes ou porque tentavam localizar suas famílias, mas, porque era um local onde eles escondiam droga e ninguém iria entrar, como a polícia, e onde eles podiam se esconder depois de praticar algum furto, roubo, tráfico de drogas ou algo do tipo. Com isso, eles ficavam na instituição de acolhimento, mas não se sentiam pertencendo ao local. Era mais um esconderijo que um local que pudesse favorecer o desenvolvimento deles. Nesse sentido, o acolhimento da sede foi desativado, restando somente o setor administrativo no local.

No dia da entrevista para esta pesquisa, os especialistas (psicólogos e assistentes sociais) iriam começar a trabalhar em regime de plantão de 24 horas seguidas para 72 horas de folga (24h X 72h). Alice não sabia se ia se adaptar, já que preferia a escala anterior, de $12 \mathrm{~h}$ X 36h. Mas percebia como uma mudança necessária, já que a instituição estava passando por um longo processo de mudanças e que ainda iria demandar tempo para estabilizar. Para ela, o trabalho em plantão foi melhor do que o regime de expediente, quando trabalhava por 8 horas 
diariamente. Como o trabalho exige muito do profissional emocionalmente, pois há envolvimento com a vida das várias crianças e adolescentes que acompanha, e é necessário acompanhar a rotina das casas lares também, existe uma sobrecarrega para o profissional. E há também o fato de as coisas não fluírem conforme o desejado e de o resultado não ser o esperado pela equipe. Assim, no trabalho em regime de plantão, há uma folga entre os dias trabalhados, o que ameniza a pressão sobre o trabalhador.

Sobre o projeto político pedagógico da unidade, ainda não conseguiram avançar. Segundo Alice, vários fatores dificultavam essa construção. O primeiro ponto é a distância da diretoria, responsável por todas as unidades de acolhimento institucional, da Unidade, pois nem sempre estava presenta na instituição. Mas ela compreende que uma diretoria com poucas pessoas não consegue acompanhar todas as unidades de perto. O setor de recursos humanos também deveria estar mais próximo, o que não ocorria. Já iniciaram a discussão do projeto político pedagógico diversas vezes, mas nunca avançavam e estavam sempre recomeçando. Alice já se cansou de sempre discutir as mesmas coisas e nunca finalizar o projeto. Ela não compreendia porque as coisas não fluíam no sentido de concluírem esse trabalho.

Em relação à equipe de especialistas da unidade, todos estavam dispostos a finalizarem o projeto. Eles concluíram a parte de regras e procedimentos da instituição, faltando indicar o pessoal necessário para se trabalhar no local e suas atribuições. Se propuseram a escrever sobre essa parte também, mas não foram autorizados, por não ser de competência deles. Já existia um setor de recursos humanos na Secretaria, mas esse setor até então não tinha elaborado essa parte do texto. É sobre a lógica da engrenagem indicada por Alice, não adiantava uma parte funcionar se a outra não funcionar. Existia uma cobrança do Ministério Público sobre a finalização desse projeto e Alice pensa que existia algo nas instâncias superiores que travavam esse processo, já que a equipe estava disposta a finalizá-lo. 
Em 2010 iniciou-se uma discussão com a Promotoria dos Direitos da Infância e da Juventude sobre o acolhimento emergencial de crianças e adolescentes, incluindo conceitos e procedimentos. Essa discussão foi retomada e agora estão precisando, com urgência, implantar a central de vagas. Essa central receberia a criança ou o adolescente no momento do acolhimento institucional e, ao avaliar a situação, encaminharia o menino ou a menina para reintegração familiar, para uma casa lar governamental ou para uma instituição privada e com convênio com o Estado. Mas a diretoria, responsável por todas as unidades de acolhimento da Secretaria, também propôs que os especialistas, além do trabalho junto aos acolhidos, acompanhassem as entidades conveniadas, onde esses profissionais seriam responsáveis pela execução do convênio entre unidade privada e Governo, sendo que os especialistas não concordaram. Ainda estão discutindo esse ponto. Na central também fariam o gerenciamento das vagas dos abrigos conveniados.

Ainda estão decidindo alguns detalhes, mas a proposta da equipe é dessa central de vagas funcionar como um primeiro acolhimento, onde a criança ou o adolescente pudesse realizar algumas atividades no próprio local, enquanto o caso fosse avaliado pelos especialistas. Eles não seriam matriculados na escola nesse primeiro momento, até decisão do melhor encaminhamento. Para esse primeiro momento, haveria uma pedagoga que ficaria com esses novos acolhidos, executando com eles algumas atividades pedagógicas. Essa proposta foi apresentada por Alice, a partir de sua experiência quando era estagiária, e foi aceita pelos demais profissionais e pela diretoria.

\subsubsection{Situação geral da instituição}

Quanto ao público mais comum que chegava para o acolhimento, Alice apontou que recebem muitos adolescentes envolvidos com droga, atos infracionais, exploração sexual, 
alguns com orientação sexual diversa, como travestis e transexuais e alguns com situação de rua. Um problema que ocorria há muito tempo era o encaminhamento de adolescentes, autores de ato infracional, para a instituição de acolhimento, quando os profissionais do sistema socioeducativo não buscavam ou não localizavam a família do adolescente. E esse era um ponto delicado, pois, após aplicação da medida protetiva de acolhimento institucional, era mais difícil reverter essa situação, já que seria necessária decisão judicial para tal.

No momento da entrevista, a instituição funcionava com dois focos. Um era o acolhimento em casas lares, que recebiam até 10 crianças e adolescentes. $\mathrm{O}$ outro era o abrigo institucional, único local da cidade que fazia o acolhimento emergencial, que é aquele para o qual o menino ou menina é encaminhado numa situação de urgência, sem conhecimento judicial prévio. No abrigo, também avaliavam os casos que chegavam no intuito de encaminharem para instituições de acolhimento conveniadas.

Para Alice, o objetivo principal do acolhimento institucional é a reintegração familiar da criança e do adolescente na família de origem ou em família substituta, quando for o caso. No caso das casas lares, a reintegração ocorre, pois é possível que os especialistas realizem um acompanhamento mais efetivo da situação do acolhido e trabalhe em rede, o que facilita a reintegração.

Já no abrigo institucional, as reintegrações eram realizadas de forma mais imediata, resolvendo acolhimentos emergenciais quando não há necessidade de encaminhamento para acolhimento em casa lar ou em outra instituição. Exemplo: quando um menino se perde e a polícia o leva para o abrigo, geralmente dá para encaminhá-lo para sua família no mesmo dia. Nesse caso, o Conselho Tutelar é acionado para fazer um acompanhamento dessa família. Assim, os casos de rápida reintegração são de muita responsabilidade do especialista, já que não há tempo para um estudo aprofundado sobre o caso. É importante sempre acionar o Conselho Tutelar e o CREAS da região para fazer um acompanhamento dessa família e 
confirmar se não há situação de violação de direitos. O CREAS, Centro de Referência Especializado de Assistência Social, é um equipamento público que oferta o Serviço de Proteção e Atendimento Especializado a Famílias e Indivíduos que estão com seus direitos violados.

Mas mesmo sem tempo para um estudo aprofundado, no caso de crianças e adolescentes acolhidos emergencialmente, o encaminhamento à família evita que eles sejam institucionalizados sem necessidade. Após 24 horas, se a reintegração não ocorre, os especialistas precisam comunicar ao judiciário a situação de acolhimento e a criança ou o adolescente é encaminhado para uma casa lar para acompanhamento especializado.

\subsubsection{Casos de sucesso e de insucesso}

Como casos de sucesso, Alice indica que são aqueles onde é possível ver uma evolução da situação ao longo do acompanhamento. Citou o exemplo da adolescente Jussara, que chegou à instituição vindo de um contexto de brigas e ameaças onde morava, por envolvimento com tráfico de drogas. Ela era muito inteligente e líder, mas utilizou essa liderança na Unidade de forma negativa junto às demais meninas, já que conseguiu envolver muitas delas na exploração sexual. Com isso, ela conseguia dinheiro para comprar drogas. Era muito distante da família, mas ao longo do acompanhamento, que incluiu internações para desintoxicação do uso de drogas, mudança de casa lar, recaídas e muita insistência de Alice em aproximar Jussara da mãe, houve evolução. Essa mãe também passou a se movimentar para retomar seu papel de mãe junto à filha. E, no momento da entrevista, Jussara estava morando com a mãe e fazendo estágio no ministério público da cidade. Então, a média de tempo para se observar progressos na vida de uma criança ou adolescente acolhido é de pelo menos, três anos. Como exemplo de caso que "não deu certo", Alice citou a situação da adolescente Luana, pois percebe que não atuou de forma satisfatória e se cobra até hoje por isso, pois acreditava que 
era possível resgatá-la. Ela conheceu Luana quando começou a trabalhar na instituição mas, como acompanhava em torno de 40 acolhidos ao mesmo tempo, não conseguiu "pegar na mão" de Luana e ficar próxima dela. A adolescente evadia com frequência da instituição para ficar na rua, pois não aceitava o acolhimento, e pela instituição misturar acolhidos com e sem vivência de rua. Então, Alice acredita que essa mistura de perfil dos acolhidos, com e sem vivência de rua em uma mesma instituição, não funciona.

\subsubsection{Profissionais e acolhidos}

Sobre estar próximo de um acolhido, Alice pontuou que é estar junto nas atividades do cotidiano, incentivando quanto ao banho, refeições, ir ao médico. Por mais carente que os acolhidos sejam, a relação inicial com a equipe da instituição de acolhimento é de desconfiança. Então, a criação de um vínculo de confiança entre um acolhido e um profissional do abrigo demanda tempo e, quando isso ocorre, é importante "pegar na mão" e estar junto dele. Mas nem todos os acolhidos se vinculam aos profissionais.

Quanto às habilidades dos acolhidos, eles conseguem se organizar muito melhor do que os próprios funcionários do abrigo. Eles focam em um objetivo em comum e são leais entre eles quando o objetivo é único. Mesmo que haja rixa entre alguns, se o objetivo for enrolar um cuidador, certamente vão se unir para alcançar esse objetivo. Também conseguem se articular muito bem, pois quando chegam em uma instituição de acolhimento, provavelmente já passaram por atendimento de outros tipos de unidade do sistema de garantia de diretos, como Conselho Tutelar ou CREAS. Eles conhecem essa rede, como as instituições funcionam e conseguem manipular esse sistema a favor deles. Eles aprendem a lidar com esse sistema a partir do que viveram antes do acolhimento.

Na intervenção com o adolescente, na coconstrução do seu projeto de vida, caso ele proponha um caminho prejudicial, Alice sempre tenta esclarecer o que pode ocorrer com esse 
tipo de escolha e busca sempre trabalhar no sentido da ressocialização desse adolescente. E lembra que assim como a escolha é dele, a responsabilidade é dele também. E caso seja encaminhado para cumprir medida socioeducativa em regime fechado, ela avisa que não vai visitá-lo diversas vezes, mas só quando for possível. Assim, Alice busca reforçar a responsabilização do adolescente frente às suas escolhas. E também, vai colocando as regras da instituição para ele seguir, como os horários da rotina da casa. Ressalta que, quando o acolhido sente-se pertencente à instituição de acolhimento, ele se vincula aos profissionais e aceita a proposta da instituição, sendo, assim, mais fácil trabalhar com ele.

\subsubsection{Sugestões de Alice para o acolhimento}

Sobre mudanças que Alice gostaria de ver na instituição onde trabalhava no momento da entrevista, Alice falou porque sabia que ninguém iria ouvir. Para ela, os cuidadores sociais precisam realmente estar preparados e querer exercer essa função, já que seu papel é extremamente importante no desenvolvimento social da criança ou adolescente acolhido. Eles vão substituir o papel dos pais dos meninos e meninas e não podem repetir uma relação negligente com eles. E, na prática, era comum que a instituição de acolhimento, local que deveria garantir direitos, acabasse violando direitos dos acolhidos pelo não preparo da equipe para o trabalho.

Quanto às mudanças no espaço físico, Alice pensa ser importante uma reforma das casas, garantindo chuveiro quente, cama e cobertor para todos os acolhidos, além de disponibilizar um espaço para os cuidadores ficarem mais próximos dos meninos e meninas na casa. Como estava, o espaço físico não favorecia uma boa interação entre cuidadores sociais e acolhidos.

Além do mais, Alice pensa ser importante a realização de atividades dentro da unidade, com objetivos definidos, a partir do previsto no projeto político pedagógico. Para isso, é 
importante aumentar o número de cuidadores sociais e de funcionários do setor administrativo.

Para isso, era importante um remanejamento de servidores públicos dentro da Secretaria, no qual os que fossem trabalhar com acolhimento, quisessem estar lá, acreditassem na proposta da unidade e acreditassem nas crianças e adolescentes acolhidos. Seria importante também que fosse feita uma capacitação profissional da equipe, focada no tipo de trabalho existente na Unidade.

\subsubsection{Visão de Alice sobre Simone}

Simone tinha um pai extremamente violento, mas moravam ela, os pais e os irmãos todos juntos. Um dia sua mãe, que estava grávida do sétimo filho, saiu para o parto e não retornou mais, falecendo no hospital. O pai de Simone não soube lidar com a situação e iniciou um processo de alcoolismo. Inicialmente, agrediu as filhas, chegando, inclusive, a amarrar Simone.

Nesse contexto, Simone e dois irmãos gêmeos, os únicos que não foram aceitos pela família, chegaram na instituição onde Alice trabalhava, na mesma época de Alice e os novos profissionais também começaram a trabalhar no local. Então, Simone foi acolhida após uma experiência familiar bem difícil e os especialistas que a acompanhavam não tinham muita experiência na área do acolhimento institucional. Ao chegar na instituição, Simone gritava muito e ninguém conseguia chegar perto dela. Ela também tinha uma marca no rosto, oriunda de uma picada de aranha, favorecendo sua baixa auto-estima.

O foco da intervenção com Simone foi o da reintegração familiar, mas a adolescente foi rejeitada desde o início. Com o passar do tempo, o foco mudou para a promoção da autonomia de Simone mas, para ela, foi muito pesado e ela não conseguiu dar prosseguimento a esse processo, ela não estava preparada. Para Alice, era preciso trabalhar muitas questões 
emocionais com Simone. Por exemplo: ela era muito agressiva e afastava as pessoas dela, mas ninguém compreendia que essa era uma forma dela pedir socorro. Mesmo que um profissional soubesse desse pedido de socorro, a agressividade de Simone impedia uma aproximação entre eles. As especialistas que a acompanhavam sabiam que ela precisava de atendimento psicológico, mas a adolescente não aderia a qualquer intervenção profissional.

Logo no início, ela se vinculou à rua e só voltava para a instituição em razão dos irmãos que ainda estavam acolhidos. Também se envolveu com drogas e, o que Alice sabe, é que Simone não havia usado drogas antes do acolhimento. Com o tempo, a adolescente se vinculou com meninos e meninas da unidade que tinham o perfil como o dela. Para Alice, os acolhidos se aproximam e se vinculam com os que são parecidos com eles ou gostam e fazem as mesmas coisas. Simone era próxima de alguns meninos que eram líderes e envolvidos com o tráfico de drogas. A questão dela sempre foi o tráfico.

Não havia muitos profissionais que gostariam de trabalhar com ela na instituição, Alice observava que alguns funcionários, muitas vezes de forma inconsciente ou por não compreender Simone, contribuíam para a construção da agressividade de Simone e boicotavam os pequenos passos que ela dava. Por exemplo, se uma cuidadora social fosse levar Simone com seu próprio carro para a escola, havia um grupo que falava que a cuidadora não poderia transportar acolhido em carro próprio. Mas Alice hoje questiona se o problema era realmente uma proibição real de um funcionário sair com um acolhido em seu carro, ou se o problema surgia porque era Simone a ser levada para a escola.

E ao longo do acolhimento, Simone começou a fazer o que a maioria dos adolescentes fazia, articulando as situações ao seu favor e fazendo chantagem. No geral, ela fazia escolhas que muitas vezes eram negativas, mas culpava outras pessoas por essas escolhas. A questão da responsabilização de Simone precisaria ser melhor trabalhada. Várias vezes Simone começou um tratamento para parar de usar droga e de fumar para poder, após um tempo de 
abstinência, fazer uma cirurgia plástica para reparar a marca que ela tinha no rosto, mas o tempo todo ela se boicotava e não dava prosseguimento ao tratamento.

Depois que a adolescente mudou de casa, ainda dentro da Instituição A e passou a ser acompanhada por Alice, essa começou a ver mudanças. Alguns cuidadores sociais também se aproximaram dela e "pegaram na sua mão", ficando do seu lado até ela ir para escola, por exemplo. Mas um dia, seu namorado, que era um adolescente também acolhido na mesma instituição, morreu no terreno ao lado de overdose e Simone teve outra recaída. Foi difícil, pois ela ainda não tinha elaborado a morte da mãe. Várias vezes disse que gostaria de enterrar uma bonequinha dentro de uma caixa de fósforo quando a mãe morreu.

Depois, Simone falou que fazer um estágio a ajudaria e, assim, ela foi a única adolescente a ser aprovada para fazer estágio nos Correios. Ela começou a fazer estágio e foi transferida para uma casa lar A1, em outro endereço, sendo esse um local que recebia até 10 acolhidos e possibilitava um acompanhamento mais próximo. Após um tempo, Simone teve uma recaída e foi transferida para outra Casa Lar A2, a fim de evitar que ela voltasse a se envolver com drogas. Essas duas casas lares eram vinculadas à administração do abrigo institucional no qual a adolescente estava acolhida. Mas como também Simone passou por uma recaída na última casa lar, os profissionais a transfiram de volta para o abrigo institucional A. Nesse percurso, ela perdeu o estágio nos Correios, mas foi aprovada em um projeto que previa, além de aulas da escolarização regular em um período do dia, cursos profissionalizantes no turno contrário.

Mas, como última estratégia de evitar outra recaída de Simone, que estava prestes a completar 18 anos, a equipe da instituição decidiu transferir Simone para outro local. Assim, após ficar alguns anos no mesmo local, ela foi para outra Unidade de Acolhimento, com outra administração, outros profissionais, outros acolhidos. Pensaram que um outro local, com pessoas novas e outras intervenções pudessem ser benéficos para Simone. Alice pontuou que, apesar de trabalharem com vidas, sempre havia risco nas decisões tomadas. No caso de 
Simone, apostaram que daria certo, como ocorreu com outras meninas que após a transferência, começaram a trabalhar. Mas não foi o que aconteceu.

Na nova instituição de acolhimento, Simone teve dificuldades de relacionamento, quis colocar fogo na instituição e quase bateu no dirigente da unidade. Após um curto espaço de tempo, Simone se envolveu com um adolescente que já tinha sido acolhido na instituição anterior e evadiu do local com ele. A última notícia que Alice teve de Simone era que a adolescente estava em uma praça na região da instituição de acolhimento, descalça e com o cabelo bagunçado, local esse onde era comum o uso e o tráfico de drogas. Essa situação mexia muito com Alice, pois, ao vê-la na rua usando crack, percebia que esse era um caso que não havia dado certo. E Alice sentia-se mal porque a acompanhou e, de uma certa forma, não conseguiu contribuir em relação à vida de Simone. Depois Alice complementa e diz que ao falar da própria atuação que não obteve sucesso, refere-se à instituição como um todo que não havia conseguido contribuir a história de Simone.

Assim, por mais que o sistema seja frágil, Alice não conseguia ver quem poderia ajudar Simone na rua, já que era difícil uma maior aproximação com ela. A adolescente não se abria com qualquer um, principalmente em relação à sua vida. Alice se preocupava com ela enquanto ser humano e se preocupava com o que ia ser dela enquanto ser humano. Para Alice, todos os sujeitos possuem "dois animais" dentro de si, o bom e o ruim. E Simone tinha tudo para alimentar só o bom, mas na rua iria alimentar somente o ruim.

\subsubsection{Visão de Alice sobre Marcos}

Assim como Simone, Alice vê Marcos como uma vítima do sistema. E a vítima, com o tempo, se transforma no agressor. Isso se deu com Marcos pois, desde quando foi acolhido ainda bebê, não foi trabalhada a questão da reintegração familiar. Se tivessem buscado a família de Marcos quando ele ainda era criança, assim como a pesquisadora fez, Alice se 
questiona se teria sido necessário o longo tempo de acolhimento pelo qual ele passou. Ele sempre colocava que se sentia um lixo e, com a transferência dele da segunda instituição de acolhimento, onde praticamente foi criado, para a terceira instituição, onde Alice trabalhava, reforçou esse sentimento.

As instituições de acolhimento pelas quais Marcos passou contribuíram negativamente na vida dele. A primeira não procurou sua família. Já na segunda, eles até faziam um trabalho interessante, reinserindo os acolhidos na comunidade, mas não focavam na reintegração familiar, além de não saberem lidar com o período da adolescência. Quando Marcos começou a usar maconha, eles o transferiram para outra unidade diferente, com outra rotina, outras pessoas. Eles o abandonaram. Ele perdeu sua referência e foi reforçado nele um sentimento de não ter valor. Marcos foi abandonado diversas vezes, sendo essa a segunda vez. De forma semelhante à Simone, a personalidade de Marcos contribuiu para as pessoas desistirem dele.

Marcos sempre reagia com agressividade. Uma vez tentou queimar uma das casas que ficava no abrigo institucional onde Alice trabalhava. Também era um menino bonito e se aproveitava dessa beleza para se aproximar das meninas. Ele tinha uma liderança perante os demais acolhidos, mas a utilizava de forma negativa. Marcos era um dos meninos que não se sentia pertencente à instituição de acolhimento, mas utilizava o local como espaço de segurança e de fuga da responsabilização dos atos dele.

\subsubsection{Movimento instituição de acolhimento/ rua e vice-versa}

Para chegarem na situação de rua, existia certa desestruturação na família das crianças e dos adolescentes, além de uma falta de suporte dessa família. Também, a situação socioeconômica desfavorável fazia muitos buscarem na rua o que não era suprido em casa. Com isso, se deslumbravam, pois tinham tudo na rua, que funcionava como um parque de diversões. Eles tinham comida porque muita gente oferecia, tomavam banho quando queriam 
e do jeito deles, tinham liberdade. Existiam muitos atrativos na rua. Então, algo que ocorria no âmbito familiar, favorecia o distanciamento da criança ou do adolescente da própria família e a busca de auxílio na droga ou no grupo de amigos. Vários fatores levavam ao acolhimento institucional, mas para Alice, a dificuldade na família era o principal motivo.

$\mathrm{Na}$ rua, os meninos e as meninas se organizavam e tinham suas prioridades, vigiavam carros e até faziam pequenos furtos no comércio local. Mas voltavam com frequência para a instituição, pois era uma forma de fugir da própria responsabilização do que faziam fora da unidade. Fugiam da polícia e do traficante de drogas quando eram ameaçados. Quando tinham algum tipo de arma, era na instituição de acolhimento que a escondiam.

Para o desenvolvimento do menino e da menina, Alice acredita que esse movimento de ir e voltar entre a instituição de acolhimento e a rua é fundamental, e acredita que é nesse movimento que o profissional consegue fazer algum tipo de intervenção. Não tem como trabalhar com esse público específico sem considerar a importância que a rua tem na vida deles. Então, a rua é importante e deve ser considerada na intervenção profissional. É essencial trabalhar a rua e a rua na vida deles. E a resposta aparece após um longo tempo.

\subsubsection{Considerações}

Alice pontuou, ao final da entrevista, que ao falar sobre sua experiência profissional, era como se "voltasse isso para dentro" e viu o quanto é delicado trabalhar com a vida das pessoas. Também favoreceu para que ela refletisse o que estava fazendo pelos acolhidos. 


\subsection{NÍVEL TEMÁTICO: ASPECTOS ORGANIZACIONAIS SOBRE O}

\section{ACOLHIMENTO INSTITUCIONAL DE ADOLESCENTES}

A análise temática referente à trajetória profissional de Alice foi realizada a partir dos elementos identificados na análise descritivo-cronológica da narrativa da participante. Buscou-se, então, destacar aspectos organizacionais do acolhimento institucional de adolescentes, que se fizeram presentes na história narrada por Alice. Como parâmetro de análise, considerou-se que existem quatro facetas em relação ao trabalho, como indicou Dujarier (2012a). Uma é o trabalho prescrito, sendo aquele orientado por normas, regulamentos e legislações e que se refere ao que é formalmente demandado aos trabalhadores, organizado e controlado pelos gestores. "Trata-se de uma definição de resultados esperados, de procedimentos a serem seguidos, de comportamentos a serem adotados e, mesmo, da subjetividade necessária ${ }^{1 "}$ (Dujarier, 2012a, p. 53)

A segunda faceta do trabalho apresentada por Dujarier (2012a) diz respeito ao trabalho real, sendo aquele que não segue o trabalho prescrito e que aparece na forma de erros, falhas, desorganização, redução da ação ou da fala dos trabalhadores, muitas vezes ocorrendo de forma invisível e imprevisível. Como terceira faceta, tem-se o trabalho realizado, que é a parte visível da ação dos profissionais, alvo de avaliação e julgamento dos gestores. A lacuna entre o trabalho prescrito e o trabalho realizado é objeto de preocupação para os profissionais e gestores, na medida em que mostra a não eficiência das ações empreendidas. Porém, ao mesmo tempo, indica que situações contraditórias fazem parte do cotidiano do trabalho e que essa lacuna aponta, muitas vezes, a distância entre o trabalho ideal e o trabalho possível de ser realizado.

\footnotetext{
${ }^{1}$ Tradução livre realizada pela autora desse texto.
} 
E por fim, existe o trabalho vivido que, segundo Dujarier (2012a), é relativo à interpretação subjetiva e ao sentido conferido à ação em curso, assim como à ação já realizada e que ainda será executada. Nesse caso, são incluídos as condições de realização do trabalho, o status objetivo e a imagem social atrelada à esse contexto. Vale ressaltar que o trabalho vivido se apresenta de formas diferentes, dependendo de qual será o interlocutor, como por exemplo, um amigo, um colega de trabalho ou ao gestor responsável pelo setor. Assim, por meio da identificação dessas quatro facetas do trabalho, é possível que se apreenda não só elementos concretos e visíveis, mas também, aspectos invisíveis e subjetivos desse contexto.

A partir da narrativa da trajetória profissional de Alice, buscou-se acessar a faceta do trabalho vivido, sua interpretação subjetiva de experiências relacionadas à atuação profissional. Também, buscou-se apreender de que forma o trabalho prescrito, o real e o realizado, sobre acolhimento institucional de adolescentes, se fizeram presentes.

\subsubsection{Busca constante da compreensão do outro}

O tema compreensão da história de vida aparece na narrativa de Alice desde sua formação profissional. Ao fazer psicoterapia, buscando maior compreensão de si mesma, ainda no Ensino Médio, ela havia escolhido cursar graduação em Psicologia, sua primeira opção, ou Serviço Social. Acabou sendo aprovada em vestibular para o segundo curso escolhido. Durante a faculdade, mudou-se de uma cidade pequena para outra maior, no mesmo Estado, estagiou junto a adolescentes em medidas socioeducativas de Liberdade Assistida e Prestação de Serviço à Comunidade, em um ambulatório de saúde, em um Delegacia da Mulher, atuou com mediação de conflitos e em um call center, frisando que esse último era somente para melhorar sua situação financeira, já que não gostava desse trabalho especificamente. Alice afirmou que o que mais gostou foi de trabalhar com adolescentes pois, para ela, havia uma identificação entre sua história e a deles. O período da adolescência foi para ela uma fase 
conturbada, pois não se sentia compreendida por seus familiares, ao tomar atitudes que não eram aprovadas por eles. Então, ao ter consciência de que essa experiência não havia sido positiva para ela, se esforçava sempre para compreender os adolescentes com os quais trabalhava, pois sabia como era ruim não ser compreendida. Assim, Alice buscava entender os motivos pelos quais eles faziam certas escolhas, tais como usar drogas e passar vários momentos na rua. Vale ressaltar o termo que Alice utilizou, ao frisar que "se esforçava" para compreender os adolescentes, indicando que essa não é uma postura profissional que se adquire de uma só vez, mas que exige uma atenção constante do trabalhador que intervém em contextos onde há adolescentes. Para cada menino ou menina com quem se trabalhe, é importante que se identifiquem motivações e formas com que resolvem conflitos, que variam conforme a história de vida de cada um.

Além do mais, Alice identifica sua implicação no trabalho com adolescentes. É claro para ela que questões relacionadas à própria história de vida estão sempre presentes em sua atuação profissional, se inter-relacionando às suas práticas. Assim, quando o profissional possui esse conhecimento, ele percebe que seu trabalho prescinde de relações intersubjetivas (Amado, 2005) e não vê o outro como um ser distante sobre o qual ele atua de forma, suspostamente, neutra. Além do mais, ele consegue identificar melhor quais os efeitos dessas relações intersubjetivas sobre ele mesmo.

Especificamente sobre acolhimento institucional com adolescentes, Alice trabalhou nesse contexto quando ainda cursava Serviço Social, enquanto estagiária. Essa experiência foi positiva, a ponto dela escolher atuar novamente em uma instituição de acolhimento tempos depois. Sobre os pontos que Alice qualificou como positivos, observa-se que eles estavam relacionados à organização da instituição, com procedimentos claros a serem seguidos pelos profissionais, como a utilização de um quarto onde o adolescente ficava inicialmente, quando esse decidia sobre a aceitação do próprio acolhimento, além de um trabalho inicial com uma 
pedagoga, que ocorria de forma a preparar o adolescente para sua inserção no ensino regular. Havia também estímulo à participação dos acolhidos na dinâmica da instituição, com o auxílio deles na preparação das refeições e na limpeza e organização do local. Para Alice, a escolha por parte deles em serem acolhidos fazia toda a diferença e aproximava os adolescentes do contexto institucional. Considerando a importância que Alice dava à compreensão da história de vida e das escolhas dos adolescentes, o trabalho participativo dessa instituição agradou ela. Também, por mais que muitos acolhidos voltavam a passar dias na rua, fazendo uso de drogas, ela tinha clareza de que esse processo de saída da rua era longo, podendo chegar a três anos. Mas ela observava que a cada volta à instituição, o adolescente estava "um pouco melhor", como disse, referindo-se ao distanciamento progressivo da dinâmica de sobrevivência nas ruas. Nesse contexto, indica-se que a instituição possui papel importante para apoiar esse processo do adolescente, mesmo que leve ao sentimento de frustração a muitos profissionais que ali atuam. Assim, para Alice, é importante gostar e acreditar que o trabalho possa ter resultados positivos na vida dos adolescentes, mesmo que esses resultados apareçam após um longo período de atuação. Para que isso ocorra, a instituição tem papel fundamental no sentido de se organizar e atuar, sempre considerar todo o contexto de vida do adolescente.

\subsubsection{Peça de uma engrenagem}

Após sua formação em Serviço Social e de suas experiências profissionais, Alice mudouse para Brasília, e passou a trabalhar em uma unidade de internação provisória para adolescentes autores de ato infracional. A gestão do local ficava a cargo de um grupo de padres. A instituição funcionava, segundo Alice, como uma grande engrenagem na qual as peças se encaixavam em harmonia. Os profissionais eram, então, pressionados a "funcionar", como se fossem peças de uma grande engrenagem, que não podiam falhar na sua função. Eles 
sabiam qual era o Projeto Político Pedagógico da instituição, a rotina a ser seguida, os protocolos a serem empregados, além de qual postura era a mais adequada a ser adotada nesse contexto. Alice pontuou que esses elementos favoreciam o bom andamento do trabalho e deveriam servir de modelo para qualquer contexto laboral. Mas, ao mesmo tempo, ela pontuou que o trabalho era bastante cansativo e desgastante, e que o comprometimento dos profissionais se dava pelo medo de serem demitidos do emprego. Para equilibrar a sobrecarga de trabalho, a equipe contava com supervisão constante do coordenador, que monitorava o trabalho e ouvia com atenção as dificuldades dos funcionários.

Nesse local, o trabalho prescrito era explícito a todos e o trabalho realizado era avaliado constantemente pelos gestores da instituição, o que ocorria de forma a acolher e auxiliar os profissionais a se adaptarem às normas e aos procedimentos estabelecidos. Alice vivenciou seu trabalho nesse local de forma satisfatória, afirmando que ficou muito triste quando foi aprovada em concurso público e saiu desse emprego, já que amava esse trabalho, como ela pontuou. A escolha para realizar concurso público deu-se após pressão dos colegas, que alegavam ser a melhor opção, tendo em vista a estabilidade do emprego.

Então, assim como quando trabalhou em unidade de acolhimento de adolescentes em situação de rua quando era estagiária, para Alice, a organização das instituições, por meio de procedimentos e fluxos definidos e explícitos, era vivenciado de forma positiva pelos trabalhadores, pois favorecia o bom andamento dos trabalhos. Favorecia, inclusive, uma diferenciação entre a atuação do psicólogo e do assistente social, o primeiro trabalhando em grupo com os adolescentes, e o segundo ficando a cargo das visitas domiciliares. Como ela afirmou, por meio das prescrições em relação ao trabalho, os trabalhadores, que começavam a agir conforme eram orientados, sem opção para agirem de forma diferente, passavam a gostar do que faziam. 


\subsubsection{Da ordem à desordem}

Após ser aprovada em concurso público, Alice foi trabalhar em uma Instituição pública de Acolhimento para crianças e adolescentes. Diferentemente de suas experiências anteriores, ela se defrontou com um local onde os procedimentos e fluxos de trabalho não eram prédeterminados, o que a fez sofrer por pelo menos um ano. Os papéis do psicólogo e o assistente social também não eram distintos, sendo que os dois profissionais atuavam da mesma maneira. Para Alice, a estabilidade do emprego público afastava a possibilidade de compromisso dos profissionais em relação ao seu trabalho. Mas vale ressaltar que essa visão não considera que a grande maioria dos psicólogos, assistentes sociais, pedagogos e cuidadores sociais que ali estavam não conheciam o Serviço de Acolhimento e o trabalho que deveriam realizar, pois não tinham tido experiências anteriores nesse tipo de contexto. Então, por mais que Alice tivesse clareza do que deveria ser feito, muitos não o sabiam. Além do mais, segundo ela, todo o sistema era falho, o que prejudicava o bom andamento dos trabalhos, pois não havia supervisão constante das atividades e o setor de Recursos Humanos não tinha autonomia necessária para agir junto aos profissionais.

A Unidade de Acolhimento funcionava com casas lares descentralizadas e com um abrigo institucional, onde havia cinco casas com capacidade de até 10 acolhidos cada. No abrigo, segundo Alice, muitos acolhidos usavam esse espaço para esconderem drogas e fugirem quando eram ameaçados na rua, ou seja, era mais um esconderijo e não um local de pertencimento para os adolescentes, que era a maioria dos acolhidos. Havia poucas crianças nesse espaço.

Após alguns meses da entrada de Alice no local, foi necessário que se estabelecesse o Projeto Político Pedagógico (PPP) da instituição, já que esse documento, necessário à orientação dos trabalhos, não existia. Esse seria, então, o principal orientador do serviço, onde estariam os principais objetivos e diretrizes relacionadas à atuação da equipe. Mas, até o 
momento da entrevista, mais de dois anos após o início das discussões sobre a elaboração do PPP, o documento não havia sido finalizado. Parece que a falta de organização institucional, relatada por Alice como a inexistência de engrenagens que se encaixavam num sistema, impediam também a finalização do documento que deveria organizar o próprio trabalho. $\mathrm{O}$ trabalho real (Dujarier, 2012a), nesse caso, estava relacionado ao não se organizarem para construírem o PPP da instituição, que era de elaboração conjunta da equipe, o que aparecia com o trabalho realizado, no caso, com a não finalização desse documento.

Sobre a relação dos profissionais com os acolhidos, Alice destacou que antes de tudo, é importante que seja estabelecida uma relação de confiança para, em seguida, esse profíssional ficar próximo, "pegar na mão" e proporcionar evolução da situação do adolescente acolhido. Mas ela afirmou que nem todos os adolescentes se vinculavam a algum profissional da instituição de acolhimento. Para Alice, o projeto de vida precisa estar relacionado à ressocialização do adolescente, que só é possível de se organizar depois do adolescente sentirse pertencendo à instituição de acolhimento e aceitar a proposta do que lhe é ofertado. Esse é um ponto interessante, pois como destacou Gaulejac (2007e), muitas vezes existe uma oposição entre o projeto institucional e o projeto de vida do adolescente acolhido. Esses muitas vezes desejam ser acolhidos e ouvidos pelos profissionais em relação aos seus projetos mas, para se adaptarem ao funcionamento da instituição, precisam nivelar suas ambições para que se encaixem aos objetivos do acolhimento, ou seja, o de reintegração familiar e/ou comunitária. Tem-se, então, um projeto de inserção que nem sempre segue na mesma linha do projeto de vida do adolescente acolhido, sendo esse um ponto de contradição com que o profissional se depara em sua atuação. O significado do termo "reinserção social" nem sempre é o mesmo para o profissional e para o acolhido.

Outro ponto interessante está na organização dos grupos que faziam parte da instituição de acolhimento. Alice pontuou que os adolescentes se organizavam melhor que os funcionários 
da instituição para conseguirem o que desejavam. Em outras palavras, a não organização sistemática do serviço de acolhimento não impedia ou até incentivava uma organização coletiva entre os acolhidos. Mas essa organização tinha por objetivos atender às necessidades dos adolescentes, como conseguir droga e passar comida pela cerca da instituição para os que tinham saído do local, a fím de ficar momentos na rua. Além do mais, esse coletivo de adolescentes se organizava de modo a ir de encontro às regras estabelecidas pelos profissionais do acolhimento, o que levava a momentos de conflitos entre acolhidos e equipe.

\subsubsection{O que poderia ser feito}

Diante do quadro apresentado por Alice quanto ao local de trabalho no qual estava no momento da entrevista, ela indicou quais seriam as mudanças necessárias para o bom funcionamento da instituição de acolhimento. Sobre a equipe, ela frisou que os cuidadores sociais possuem papel essencial para o que ela chamou de desenvolvimento social dos adolescentes acolhidos e, então, precisariam estar muito bem preparados para exercerem suas atribuições. Esse cuidado é essencial, pois não podem repetir o comportamento negligente da família de muitos que estão acolhidos. Mas na prática, a unidade de acolhimento acaba por violar direitos dos adolescentes, ao invés de protegê-los. Assim, é imprescindível que os profissionais que trabalham no campo social se interroguem sobre os efeitos de suas práticas sobre eles mesmos (Gaulejac, 2007c), que podem aparecer por meio da rejeição ao outro, do desprezo, da indiferença ou da piedade, a fim de que possam sair de uma relação de poder, de uma posição de dominação, o que favoreceria um reconhecimento mútuo, entre o profissional e o usuário do serviço de assistência social. Caso contrário, os adolescentes do serviço de acolhimento tendem a continuar se sentindo desprezados e incompreendidos e o profissional, desimplicado de qualquer ruptura que o acolhido fizer com a instituição (Gaulejac, 2006e). 
Em relação ao espaço físico, ele precisaria ser minimamente acolhedor e favorecer maior interação entre adolescentes e cuidadores sociais, pois como estava naquele momento, com falta de cobertores e lençóis e chuveiro que nem sempre estava quente, o que ele favorecia era o sentimento de indignação entre os acolhidos, que reagiam muitas vezes de forma agressiva e aumentavam ainda mais a depredação do espaço. Mas como frisou Dujarier (2012c), é comum aparecer uma lacuna entre os fins e os meios, esses em termos de recursos materiais, físicos e de pessoal disponíveis. As equipes são colocadas para atenderem uma demanda cada vez mais crescente, com os mesmos ou menos recursos disponíveis. Com isso, as queixas sobre questões concretas aparecem com frequência entre os trabalhadores, o que não é bem visto pelos diferentes níveis de gestão, pois de alguma forma, essas críticas colocam em xeque a possibilidade de se atingirem os objetivos do acolhimento, a saber, reintegração familiar e/ou comunitária, esta última por meio da autonomia do adolescente. Essa é uma das contradições que permeiam o serviço.

Outra questão relativa ao espaço físico, segundo Alice, era a importância de utilizá-lo de forma positiva, por meio de atividades que contemplassem os objetivos de um Projeto Politico Pedagógico (PPP). Mas, ao mesmo tempo, o processo de construção desse Projeto ainda não havia terminado, não ficando claro, para os trabalhadores de forma geral, de que forma poderiam atuar, concretamente, junto aos acolhidos.

\subsubsection{Simone: escapando pelos dedos}

No caso da adolescente Simone, participante desta pesquisa, é interessante observar que, por mais que ela tenha ficado durante cinco anos acolhida na instituição onde Alice trabalhava, a origem da sua marca no rosto apareceu para essa profissional, de forma diferenciada do que no momento da entrevista para esta pesquisa. Para Alice, a marca havia aparecido depois de uma picada de aranha e, para a pesquisadora, ela era fruto de uma 
agressão do seu pai, que a havia queimado, pois ele tinha certeza de que Simone não era sua filha biológica. Pode-se indicar nesse ponto que o trabalho por meio de histórias de vida com adolescentes, proporciona maiores possibilidades do menino ou da menina expressarem situações e sentimentos, muitas vezes vergonhosos. No caso da marca no rosto de Simone, ela afirmou à pesquisadora que não gostava que ficassem perguntando a ela a que se referia, ficando agressiva nessas horas. Nesse sentido, compreende-se porque ela falou de sentimentos vergonhosos, como o de talvez não ser filha biológica do seu pai e da forma como ele reagiu, queimando seu rosto, pois ela estava expressando sua história de forma livre, sem ter que se adequar a qualquer orientação institucional ou demanda profissional e, sem sofrer qualquer tipo de julgamento. Outro assunto que ficou claro na história de vida contada por Simone para esta pesquisa, mas que era de desconhecimento da equipe da unidade de acolhimento, foi em relação ao uso de drogas por Simone, quando ela ainda era criança, ou seja, bem antes do seu acolhimento institucional. Já para Alice, Simone começou a fazer uso de drogas depois do acolhimento.

Em relação ao trabalho da equipe da unidade de acolhimento, primeiramente buscou-se trabalhar com a possibilidade de reintegração familiar, o que não deu certo, pois Simone foi rejeitada por seus familiares. Então, começaram a intervir junto dela, com vistas à sua autonomia. Mas Alice pontuou que esse trabalho também não foi possível, pois era preciso trabalhar questões afetivas e emocionais antes, já que Simone era muito agressiva com a equipe e não permitia qualquer vínculo entre eles. Um ponto importante a se observar é a concepção de Alice em relação à promoção de autonomia dos adolescentes. Para ela, esse processo estava relacionado à inserção do acolhido na escola e em cursos profissionalizantes, para que pudessem ter um emprego e uma renda financeira, a fim de se sustentar na vida adulta, quando não poderia mais ficar acolhido onde estava. Alice afirmou que Simone não aderia a qualquer intervenção profissional, mas não considerou que o trabalho de questões 
relacionadas aos sentimentos dos adolescentes, expressa muitas vezes de forma agressiva, também faz parte do processo de autonomia deles, podendo ser trabalhado de forma individual e/ou coletiva.

Após um tempo do acolhimento de Simone, Alice passou a acompanhá-la de perto, "pegando na mão" dela, como afirmou, ficando próxima à adolescente. E, por mais que muitos cuidadores sociais tivessem dificuldades em lidar com a adolescente, após essa postura de Alice, esses profissionais passaram a também se preocupar com Simone. Isso indica que, por mais que uma equipe possa ter resistência a investir afetivamente em algum acolhido, um movimento contrário pode favorecer uma (re)aproximação dos profissionais junto ao adolescente, por meio da construção de vínculo afetivo, importante na ressignificação da história de vida do menino ou da menina e que permite a co-construção de um projeto de vida que contemple também, os sonhos desse adolescente.

Mas ao longo do acompanhamento de Alice em relação a Simone, sempre transferindo a adolescente de casa para que ela se afastasse do contato com drogas, Simone não conseguiu se manter longe dessas substâncias psicoativas e, a fim de protegê-la, os profissionais decidiram encaminhar a adolescente para outra instituição de acolhimento, quando ela estava com 17 anos. Mas nesse novo local, ela ficou mais agressiva e evadiu. Um tempo depois, Alice ficou sabendo que Simone estava morando na rua, em um local onde havia grande atividade de tráfico de drogas. Ao saber dessa notícia, Alice ficou muito triste e decepcionada por não ter contribuído de forma positiva na vida da adolescente. Ao mesmo tempo, afirmou que não havia sido uma falha somente da parte dela, mas de todo um sistema que não conseguiu proteger Simone.

Ao Alice pontuar falhas institucionais e sistêmicas, observam-se alguns pontos importantes. O primeiro diz respeito à abstração de determinados conceitos utilizados no acolhimento institucional de adolescentes, no que se refere aos objetivos das equipes que 
precisam promover a reintegração familiar e/ou comunitária dos acolhidos. Como indicou Dujarier (2012c), em serviços aos quais ela qualificou "de massa", que abarcam um grande número de pessoas, há uma prescrição geral sobre os objetivos da intervenção, que muitas vezes carrega conceitos abstratos, mas pouco indicam caminhos operacionais para se atingir tais objetivos. No caso do serviço de acolhimento, por mais que a capacidade de atendimento não deva exceder 20 acolhidos, para abrigo institucional, e 10, para cada casa lar, pode-se considerar um serviço de massa, na medida em que há diretrizes nacionais para esse serviço, que devem ser respeitadas e aplicadas em todo o país. E essas diretrizes trazem conceitos como reintegração familiar e comunitária e promoção da autonomia do adolescente, mas não mostram, concretamente, na prática, o que caracteriza uma reintegração, ou a autonomia, e qual o caminho a ser percorrido para se chegar a esse ponto. Ao mesmo tempo, é uma prescrição que parte de um ideal a ser buscado pelos profissionais junto dos acolhidos, idealização essa que pressupõe que o acolhido possa ser acolhido novamente por sua família, onde será protegido como nunca o foi antes; que busca promover a autonomia do adolescente que, apesar das dificuldades na escola, da qual muitos evadem, vai concluir pelo menos o Ensino Fundamental, cursar um curso profissionalizante, conseguir um emprego, alugar um lugar para morar, administrar esse novo local de moradia sozinho e não ter recaídas quanto ao uso de drogas ou vida nas ruas. São prescrições ideais e muitas vezes contraditórias, na medida em que, ao colocar a expressão reintegração, quer seja na família ou na comunidade, supõe-se que ocorra um processo de retomada de algo que se perdeu, desconsiderando que, em muitos casos, nunca houve de fato uma integração efetiva na família ou no território de moradia do adolescente. Além do mais, ao trabalhar rumo à reintegração social do acolhido, psicólogos, assistentes sociais, pedagogos, cuidadores sociais, entre outros profissionais que atuam no acolhimento institucional, também não têm acesso de forma explícita, operacionalmente, como a intervenção deve ocorrer. Muitas vezes não é dito o que significa o 
trabalho de acompanhamento desses profissionais junto aos adolescentes, ficando a cargo de cada trabalhador criar suas próprias estratégias de intervenção. Isso tudo, sem considerar ainda que existem dificuldades de adolescentes em situação de vulnerabilidade e suas famílias, no acesso e permanência nas políticas públicas de educação, saúde, habitação e segurança alimentar, que atuariam como uma rede de apoio psicossocial para eles. Todas essas situações contraditórias atravessam o trabalho dos profissionais do serviço de acolhimento, que acabam por se sentirem culpados e incompetentes para esse tipo de trabalho.

Considerando o exposto, para Alice, por mais que ela tenha "pegado na mão" de Simone, ela escorregou por entre seus dedos e escapou de seus cuidados, passando a morar na rua e continuando a fazer uso de drogas, quando estava prestes a completar 18 anos. E isso gerou um mal estar em Alice, ao mesmo tempo em que afirmou que Simone era mais uma vítima de um sistema falho. Mas para avaliação dessa situação complexa, cabe utilizar as reflexões de Gaulejac (2007c), quando afirma que é importante que se mude a forma de lidar com o problema. Ao invés de trabalhar com os acolhidos, no sentido de reinseri-los na sociedade, é essencial que se trabalhe sobre as relações sociais, institucionais, econômicas e culturais que se estabelecem entre esses sujeitos e o restante da sociedade. Esse trabalho permite que se identifiquem fatores que desestruturam relações sociais, permitindo ações dos profissionais nesse ponto. Mais do que falar para o adolescente voltar a estudar, é importante que se compreenda como se dá sua relação com a escola. Mais do que buscar a reintegração do acolhido em sua família, é essencial que se conheça como a relação entre adolescente e familiares se organiza. Mais do que tentar impedir o adolescente de ficar na rua e usar droga, é importante que se conheçam os elementos presentes e os significados da relação do adolescente e a rua ou a droga. Nesse sentido, o profissional terá dicas de como atuar no sentido de transformar essas relações, de modo a promover alternativas que sejam saudáveis e de reconhecimento do adolescente acolhido. Afinal, o trabalho com populações vulneráveis, 
incluindo o contexto do acolhimento institucional de adolescentes, requer que o profissional reconheça que, além de atender demandas de alimentação, local para dormir e vestimenta, precisam atender às necessidades que aparecem no plano das relações humanas, por meio da compreensão, da escuta e da empatia, e no plano simbólico, que se faz a partir do reconhecimento, da consideração e do respeito aos adolescentes.

\subsubsection{Marcos: de vítima a agressor}

Em relação à história de Marcos, também participante desta pesquisa, Alice salienta que as instituições de acolhimento por onde ele passou, contribuíram negativamente com sua trajetória de vida, cada uma a seu modo. Assim, para se defender das violações das quais foi vítima, passou a ser o agressor, muitas vezes afastando pessoas da equipe que buscavam estabelecer algum vínculo com ele. Essa observação de Alice vai ao encontro do que Marcos colocou em relação à sua história, quando disse que aprendeu a se afastar das pessoas antes que ele fosse abandonado novamente. Nesses casos, cabe destacar que o trabalho precisa ser realizado sobre a relação ou as relações que se estabelecem, e não sobre um pólo dessa relação (Gaulejac, 2007c). É importante que se conheça e se trabalhe a relação do adolescente com a instituição de acolhimento, acessando significados e sentimentos presentes e intervindo nos pontos de conflito e tensão entre os envolvidos, o que inclui a relação dos acolhidos com os profissionais.

\subsubsection{Síntese}

A partir da trajetória profissional de Alice, alguns elementos organizacionais do acolhimento institucional de adolescentes puderam ser identificadas. Ao falar também de sua visão sobre a história de Simone e Marcos, ela também dá pistas sobre o funcionamento desse 
contexto. Para Alice, quando a instituição apresenta normas e procedimentos e exige que eles sejam aplicados por todos os trabalhadores, todos conseguem trabalhar de forma sincronizada, o que lembra o funcionamento de uma engrenagem, uma máquina. Por outro lado, como bem pontuou Alice, os funcionários não têm opção de agir de outra forma e passam a gostar do que fazem. Cabe questionar se esse modo de funcionamento, ao não dar espaço para a criatividade dos trabalhadores, é saudável do ponto de vista subjetivo, afetivo, na medida em que eles “passam a gostar do que fazem”, dando a impressão de que isso acontece de forma mecânica, como uma saída para darem algum sentido ao trabalho realizado.

Sobre o cuidado com os acolhidos, a postura de Alice em relação à Simone favoreceu que outros trabalhadores passassem a melhor cuidar da adolescente também, como uma reação em cadeia. Isso demonstra que é possível um olhar mais acolhedor, mais próximo dos acolhidos, por parte dos profissionais mas, em um serviço de massa (Dujarier, 2012b), esse movimento ocorre como que na contramão do processo de padronização que geralmente se faz presente nesse contexto. 


\section{RELAÇÃO DA PESQUISADORA COM SUA PESQUISA: PROCESSO DE IMPLICAÇÃO}

Pesquisar por meio de uma abordagem clínica significa buscar pontos de articulação complexos entre vida psíquica, condutas e campo social do fenômeno estudado e, nesse contexto, a implicação do pesquisador é ponto fundamental a ser considerado. $\mathrm{O}$ verbo latino implicar vem do latim plicare e ambos significam dobrar e possuem como raiz a palavra grega, plek, com o mesmo significado. Outra palavra advinda dessa mesma raiz, complectere, do verbo plectere, significa entrelaçar. Assim, o termo implicação refere-se a um entrelaçamento complexo que, ao mesmo tempo em que aproxima, também pode sufocar e entrelaçar de tal forma que impede o distanciamento entre os que se entrelaçaram. Por mais que tente controlar, o pesquisador psicossociólogo clínico carrega em sua investigação seus afetos, valores, ideologias e representações, vieses esses que influenciam sua atuação no processo investigativo (Amado, 2005).

Então, se a Psicossociologia Clínica valoriza a aproximação e compreensão da subjetividade do participante, essa aproximação ocorre pela inter-relação entre duas subjetividades, a do pesquisador e a do participante, em que a empatia do pesquisador é essencial no sentido de compreender o mundo interior do outro como se fosse dele, mas sem esquecer-se de que não se trata do próprio mundo interior. Assim, na empatia do pesquisador é essencial um certo descentramento para possibilitar, nessa relação, um trabalho de autocrítica sobre sua conduta da pesquisa (Amado, 2005). Significa para o pesquisador, que ele se implique nesse processo de investigação e, além do mais, que analise essa relação, explicitando as questões que se fizeram presentes durante todo o processo de investigação (Sévigny, 2001). Nesse sentido, 
A pesquisa consiste, assim, em se interrogar permanentemente sobre ela própria, suas condições de produção, a construção dos seus objetos, as escolhas teóricas, o estabelecimento de seus instrumentos, bem como sobre as aspirações, as projeções e os desejos que o pesquisador põe em prática nas suas atividades (Gaulejac, 2001, p. 45).

É importante, então, que o pesquisador tenha claro suas crenças e ideais e identificar seus projetos explícitos e implícitos que se fazem presentes no seu estudo, indicando os determinismos sociais de sua história individual. Assim, a fim de apresentar de que forma eu me impliquei nesta pesquisa e quais elementos identificados se fizeram presentes na relação pesquisador-participante, me reservei o direito de escrever este capítulo na primeira pessoa. Como apontou Ruiz (2013b), de alguma forma nos sentimos envolvidos em determinadas questões sociais e buscamos, por meio da investigação, contribuir com a co-construção de um maior conhecimento sobre determinada temática.

Essa implicação também diz do papel político desse tipo de pesquisa, pois permite que sejam criadas alternativas de ação e transformação frente aos problemas psicossociais identificados. A análise da implicação do pesquisador mostra quais são as questões ideológicas, culturais, afetivas, institucionais e relacionais que atravessam seu olhar em relação à própria pesquisa, pois todo esse processo passa pela subjetividade do pesquisador e pode ser acessada por meio da história profissional, de investigação e da construção da identidade do mesmo (Ruiz, 2013b).

Então, um dos elementos analisados nesta pesquisa foi minha implicação com o tema do acolhimento institucional de adolescentes que, com frequência, evadem da instituição e passam tempos na rua. Consequentemente, o processo relacional com os participantes desta 
investigação também foram analisados, no intuito de apreender mais pistas sobre o fenômeno em tela.

\subsection{Processo de início deste estudo}

A presente pesquisa se iniciou a partir de minha aproximação com o adolescente Marcos que, à época, estava acolhido em uma instituição enquanto eu era coordenadora da mesma, aqui denominada Instituição A. Nesse abrigo, esse adolescente, de nome fíctício Marcos, de forma geral, apresentava dificuldades em aceitar as intervenções dos profissionais e seguir as regras da instituição. Ele estava com 16 anos e não aceitava frequentar a escola ou cursos profissionalizantes nos quais era matriculado, mesmo sendo ele a escolher qual curso estudar. Ele ocupava um lugar de liderança perante os demais acolhidos, e que, de forma geral, incitava crianças e adolescentes em situações de brigas e manipulava alguns acolhidos a fazerem algo do seu próprio interesse, como comprar drogas fora na instituição para ele.

Um tempo depois, Marcos foi para a rua e entrou em contato comigo, quando o encaminhei para a Instituição B. Como ele me pediu ajuda quando estava na rua, eu me sentia de alguma forma responsável por ele naquela nova instituição de acolhimento. Assim, buscando contribuir com a organização do projeto de vida de Marcos, propus a ele que me contasse sobre o que já havia vivenciado, me contasse sua história. Meu intuito era compreender melhor sua trajetória de vida com ele para, talvez, possibilitar que ele pudesse identificar como sua vida foi se construindo e como ele foi se posicionando nesse percurso. Talvez assim ele pudesse vislumbrar algum futuro, já que no seu discurso, ele reforçava que não sabia o que fazer a partir daquele momento.

Como ele tinha habilidade com desenhos, propus que Marcos desenhasse livremente enquanto narrava sua história pois, talvez o ajudasse a se expressar. Ele aceitou a proposta e, então, passei a ir semanalmente ao abrigo para ouvi-lo. Para Marcos, era uma forma de 
divulgar sua história para que outras pessoas soubessem o que ele havia passado para chegar onde chegou. Ele buscava uma justificativa para ser como era, e eu, buscava maior compreensão do que havia se passado nesse percurso para identificar pontos positivos que pudessem ser ampliados e utilizados no futuro. Nesse meio tempo, consegui localizar a família de Marcos, com a qual ele nunca havia tido contato.

Quando fui aprovada em seleção para Doutorado em Psicologia Clínica e Cultura, da Universidade de Brasília, conversei com minha orientadora sobre o trabalho que estava realizando com Marcos em relação à sua história de vida, e ficou claro que eu já tinha em mãos um material para começar a ser trabalhado.

\subsection{Alguns elementos de minha história pessoal e profissional}

Pesquisar por meio de uma abordagem clínica significa trilhar um caminho um tanto quanto desconhecido, mas que possibilita inúmeras descobertas. Não somente descobertas em relação ao fenômeno estudado, mas descobertas em nós mesmos. No início do meu doutorado, eu ficava me perguntando o que eu iria fazer após esta pesquisa, como poderia utilizá-la na prática, como possibilitar aos adolescentes que estão em acolhimento institucional, serem ouvidos e respeitados em suas formas de ver e sentir o mundo. Mas após um tempo, mudei o ângulo da questão: o que o doutorado fez comigo?

Ao longo desse processo, pude refletir e compreender melhor meu lugar no mundo, a partir da busca de um maior entendimento sobre os adolescentes em acolhimento institucional, que também fazem da rua um lugar de moradia, mesmo que temporária. O tema da adolescência não aparece por acaso em minha trajetória profissional e de pesquisa. Desde minha graduação passo pelo processo de análise, o que me possibilitou e ainda possibilita ter mais clareza dos elementos que atravessaram e atravessam minha história. Quando estava na adolescência, sentia falta de mais espaços de expressão sobre o que eu sentia, das minhas 
questões, o que me levou a me aproximar de outros adolescentes, na fase adulta, procurando melhor compreendê-los e ouvi-los.

No curso de graduação em Psicologia, fui bolsista de iniciação científica em pesquisa sobre crianças e adolescentes que estavam em situação de rua. No mestrado trabalhei com a questão da autonomia de adolescentes, junto a alunos do ensino médio de uma escola particular.

Depois, fui aprovada em concurso público para trabalhar como psicóloga na área da assistência social. Desde meu ingresso no serviço público, trabalhei com situações de violação de direitos, principalmente com o acolhimento institucional de crianças e adolescentes. Fui coordenadora de instituição de acolhimento por duas vezes, onde pude me aproximar dessa realidade e compreender melhor algumas questões que se fazem presentes nesses contextos. Uma das situações que mais me chamaram a atenção era, na primeira instituição, a dificuldade de alguns adolescentes se relacionarem com a equipe de profissionais e de seguirem as regras da instituição. Já a segunda instituição, por mais que existisse maior diálogo com os acolhidos, com a realização periódica de assembleias, era difícil para o menino e para a menina, romperem com o movimento rua-instituição-rua.

Nesse contexto, decidi buscar compreender melhor o que estava acontecendo com esses adolescentes por meio do doutorado. Inicialmente, pensava que ouvir o adolescente e reconhecê-lo enquanto sujeito, era o suficiente para ele construir projetos de vida saudáveis. Mas elementos do contexto social que atravessam essas histórias, muitas vezes, reverberam as trajetórias e diminuem o leque de alternativas possíveis para que eles ocupem um lugar aceito socialmente. Essa compreensão, me permitiu olhar para cada realidade de forma crítica, considerando processos históricos, culturais e sociais presentes.

Por meio do estágio doutoral realizado em Montreal, Canadá, onde fiquei por 12 meses sob a supervisão do $\operatorname{Prof}^{0} \operatorname{Dr}^{0}$ Jacques Rheáume, da Université du Québec à Montréal - 
UQAM, pude apronfudar meus estudos teóricos em Psicossociologia Clínica e cursar duas disciplinas na referida universidade: Práticas Urbanas de Intervenção Social, com o $\operatorname{Prof}^{0} \operatorname{Dr}^{0}$ Michel Parazelli e Comunicação Interpessoal nos Contextos de Saúde e Serviço Social, com a $\operatorname{Prof}^{\mathrm{a}} \mathrm{Dr}^{\mathrm{a}}$ Chantal Aurousseau. Também, conheci um local que trabalha com jovens que encontram-se em situação de rua, chamado Dans la Rue e percebi o quão importante é considerar as particularidades da população atendida para adaptar o serviço oferecido às suas demandas, e não esperar que os usuários do serviço de adequem aos trabalhos realizados pelos profissionais.

Assim, ao longo deste processo de estudo, percebi que, por mais que nos integremos a contextos complexos e paradoxais, é possível encontrar alternativas criativas que possibilitem uma vida com mais elementos acolhedores. Com isso, mudei o foco do meu olhar: ao invés de somente buscar reconhecer o adolescente enquanto sujeito, meu interesse passou a ser o de conhecer melhor o contexto social, os grupos e as instituições por onde esses meninos e meninas passam, levando em consideração elementos históricos e paradoxais que se fazem presentes, com repercussões na identidade desses. Com isso, penso que tenho mais clareza quanto aos limites institucionais, sendo possível, então, identificar possibilidades de mudanças, mudanças essas não somente para o adolescente, mas para todo o grupo social, de forma a permitir maior reconhecimento positivo de todos os seus integrantes, sejam eles jovens, profissionais ou familiares. 


\section{CONSIDERAÇÕES FINAIS}

A presente pesquisa de doutorado se desenvolveu quando a pesquisadora acessou histórias de vida de dois adolescentes que estavam, à época, acolhidos em uma instituição, além da trajetória profissional de uma assistente social, que atuava no contexto do acolhimento, alcançando seus dois primeiros objetivos específicos de pesquisa. Por meio dessas narrativas, sempre sob o olhar da Psicossociologia Clínica, foi possível ter maior conhecimento sobre aspectos da dinâmica do acolhimento institucional de adolescentes, nem sempre visíveis num primeiro olhar, mas que ocorrem num entrelaçamento entre trajetórias individuais e realidades coletivas. A proposta do título desta tese, a saber, Trajetórias Marcadas: História de Vida e o Acolhimento Institucional de Adolescentes, relaciona-se com a possibilidade de, entre histórias coletivas e histórias singulares, entre histórias vividas e histórias contadas por um terceiro, se possam estabelecer conexões entre os atores do contexto do acolhimento, para que tanto adolescentes quanto profissionais, possam não somente serem marcados por essa experiência mas, também, marcarem positivamente tanto a história dos que cruzarem seu caminho, quanto a própria história, significando essa experiência positivamente.

Assim, com a análise das histórias de Marcos, Simone e Alice, destacam-se alguns aspectos sobre o acolhimento institucional de adolescentes, que merecem atenção. A partir da análise das estratégias de sobrevivência desenvolvidas por Marcos ao longo de sua história de vida, e considerando-se que o acolhimento institucional não é uma escolha nem uma situação desejada pelos novos acolhidos, eles podem reagir a essa nova condição de várias formas, cada um à sua maneira, buscando evitar que a condição de acolhido seja internalizada e passe a compor sua identidade, condição essa que muitas vezes provoca pena ou desprezo da sociedade em geral.

Um ponto a ser ressaltado é o uso, pelos adolescentes, de estratégias individualizadas para lidarem com a situação de estarem em uma instituição de acolhimento, que, num 
segundo momento, passam a fazer uso de estratégias coletivas, grupais. A busca, com a utilização dessas estratégias, seja individual, seja coletiva, parece ser o de evitar o pertencimento a um grupo que é visto pela sociedade, como sendo formado por crianças e adolescentes vindos de uma família que falhou em suas funções de cuidado e proteção, um grupo que também coloca em xeque a capacidade dos acolhidos de desenvolverem sua autonomia e as habilidades necessárias para o convívio social. Isso pode ocorrer tendo em vista que, a priori, os adolescentes não tiveram uma vivência familiar saudável que pudesse mediar e favorecer o contato com valores apreciados socialmente, como respeito ao outro e às regras sociais, possibilidade de estabelecer relações de confiança e autocuidado. Caso contrário, eles não estariam acolhidos.

E, se por um lado, essa resistência pode favorecer a reinserção familiar e/ou comunitária dos adolescentes, já que eles não desejam permanecer no grupo dos acolhidos, por outro, pode ser um dificultador para os profissionais que trabalham nesse contexto, já que esses adolescentes não vão aderir, de pronto, às intervenções indicadas. É uma situação delicada, pois justamente o ponto que poderia ser favorável no trabalho com o adolescente, é também o que impede a eficiência na reintegração familiar e/ ou comunitária. Para que uma pessoa seja usuária da Política de Assistência Social, de modo que essa política possa atuar e favorecer a garantia de direitos aos seus usuários, é primordial que, primeiramente, essa pessoa assuma que está numa posição desfavorável e que reconheça necessitar de qualquer auxílio. Mas, como indicou Léonetti (1994b), tem-se, na verdade o reconhecimento social das falhas, tanto das famílias, quanto dos adolescentes que estão no serviço de acolhimento. Assim, o Serviço de Acolhimento, preconizado como um direito à proteção, possui significado paradoxal, na medida em que esse mesmo serviço coloca os acolhidos numa posição desfavorável socialmente. E, com isso, os adolescentes acolhidos que apresentam 
resistência à atuação da equipe profissional, estão, na verdade, recusando estar naquele lugar, não só fisicamente, mas subjetivamente também.

Nesse contexto, como estratégias da equipe profissional, cabe criar ações que valorizem as habilidades e as potencialidades dos adolescentes, coletivamente, pois o trabalho em grupo atua na constituição identitária de seus membros (Carreteiro, 1993) e pode favorecer que construam vários lugares possíveis que podem vir a ocupar num contexto social mais amplo. Favorece-se, também, nesse sentido, uma projeção para o futuro pelos próprios adolescentes, não ficando somente no uso, por parte deles, de estratégias de sobrevivência e busca de ganhos de forma imediata. E os profissionais também podem sair do imediatismo e não ficar "apagando incêndio" no cotidiano do trabalho, resolvendo situações emergenciais de brigas e desentendimentos, já que eles próprios vão poder vislumbrar possibilidades junto aos adolescentes acolhidos. Por mais que psicólogos e assistentes sociais tenham que construir o Plano de Atendimento Individual e Familiar (CONANDA \& CNAS, 2009) de cada adolescente, essa elaboração pode ser coletiva. E, por meio do reconhecimento de elementos positivos da história de vida dos acolhidos, possibilitando uma identidade valorizada naquele coletivo, aumenta-se a possibilidade de os adolescentes se engajarem nas intervenções profissionais e participarem positivamente da vida social. Mas, não se pode esquecer que, por mais que diversas intervenções sejam realizadas pela equipe da unidade de acolhimento, visando o engajamento do adolescente nas ações propostas, ele pode não aderir, de acordo com sua escolha, o que pode frustrar o profissional. Esse é um dos limites institucionais do serviço de acolhimento.

Ampliando, então, as alternativas de ação profissional quanto à questão da recusa de alguns acolhidos em ocuparem o lugar de meninos e meninas do contexto do acolhimento, além do trabalho em grupo, a instituição pode favorecer o ingresso dos acolhidos em outros grupos sociais, enquanto estiverem no local, como os ligados ao Movimento Hip Hop, aos 
esportes, ao circo, à música, à dança, entre outros. Atuando como via de acesso a grupos que trabalham por meio da linguagem artística, as unidades de acolhimento abrem outras possibilidades de reconhecimento subjetivo que valorizem os acolhidos em suas trajetórias de vida e possibilitem o uso de elementos simbólicos na expressão da subjetividade (Massa, 2010).

No caso do rap mais especificamente, um dos componentes do Movimento Hip Hop, Massa (2010), em sua pesquisa realizada com adolescentes de periferia do Rio de Janeiro e de Paris, mostra o favorecimento da função simbólica junto aos adolescentes inseridos nesse contexto musical. A expressão do vivido, dos pensamentos, das revoltas e dos desejos por meio do rap, permite uma canalização da violência para a via da linguagem, na qual ela pode ser identificada, nominada e significada por esses jovens. Os grupos de rap pesquisados atuavam nesse contexto, como continentes e solidários aos adolescentes, pois suas histórias de vida eram compartilhadas e acolhidas pelos seus membros. Assim, num território estigmatizado socialmente, os adolescentes inseridos em grupos de rap podiam criar um campo simbólico, onde elaboravam o vivido, ressignificando suas representações e imprimindo outros sentidos a essa trajetória de vida. Esse campo simbólico atuava, então, na construção identitária desses adolescentes, possibilitando uma significação e ressignificação de suas trajetórias e de seu lugar na sociedade.

Porém, como o acolhimento é uma situação transitória, temporária, outro fator que pode pesar no engajamento dos acolhidos nas propostas dos profissionais está relacionada com a evitação de outro abandono. Vincular-se, confiar no outro, contar a própria história de vida e planejar o futuro onde as relações têm um prazo para terminar, não é algo fácil, considerando que muitos adolescentes vivenciaram, em sua trajetória, algum tipo de abandono, seja da mãe, do pai ou de outro adulto que era responsável por ele. Então, evitar outro abandono também passa a ser algo primordial para esses meninos e meninas. 
Outra questão que merece atenção é o registro das informações dos adolescentes em prontuários e o uso dessas informações para orientar o trato do profissional com o adolescente e a forma da atuação da equipe com esse acolhido. É importante que se tenha registrada a história de vida de cada acolhido, com as intervenções já realizadas e os encaminhamentos efetuados, no sentido de oferecer uma continuidade nessas ações. Mas cabe uma questão: até que ponto essa história registrada dificulta a ressignificação dessa trajetória de vida? O adolescente poderia conferir outro significado à sua trajetória, se o profissional permanece ligado à versão inserida no prontuário? Em um trabalho de grupo com adolescentes acolhidos, se eles conseguirem dar outro significado à sua experiência, é importante que isso seja registrado no prontuário de cada um, orientando, inclusive, outros profissionais que venham a ler esse documento, no sentido de enfatizar o novo significado conferido pelo adolescente à sua história de vida.

O compartilhamento das informações entre a equipe, para estudos de caso, também é um ponto a ser destacado. Quando um adolescente conta sua história de vida para um profissional, de alguma maneira, ele confia nessa pessoa e estabelece uma relação com ela. Mas para um trabalho em equipe, alguns aspectos precisam ser compartilhados entre outros profissionais e, muitas vezes, apresentados em estudos de caso. Esse compartilhamento das informações pode ser visto pelo adolescente como uma traição da sua confiança, difícultando maior aproximação dele com os profissionais. Uma forma de acessar essas histórias de outra maneira, é estabelecer uma relação não entre o acolhido e o profissional, mas entre o adolescente e a instituição, já que essa relação é pautada por questões institucionais como normas, regras, procedimentos que, antes de tudo, se impõem ao acolhido (Gaulejac, 2007c). Assim, evita-se que o profissional fique sobrecarregado com as demandas do acolhido, o que pode provocar diversas reações da parte do trabalhador, que vão desde procurar fazer o que é melhor para o adolescente, colocando suas expectativas sobre o que o acolhido deve fazer, 
passando pelo cansaço de não alcançar as expectativas que depositou no adolescente, quando este não segue o que foi proposto, até ao extremo da desistência de qualquer investimento nesse adolescente, transparecendo por meio de intenso sentimento de frustração, apatia no trabalho, adoecimento e/ou comportamento aversivo ou agressivo para com o acolhido. Seria importante, então, que os profissionais fizessem os atendimentos individualizados em dupla, evitando vincular o acolhido somente a um profissional. Outra forma mais eficaz é por meio de atendimentos em grupo. Além da vantagem já apontada, do grupo ampliar as possibilidades de ser e estar no mundo para os adolescentes, as histórias apresentadas serão inseridas em um contexto institucional e não numa relação diádica. Mas, nesse contexto, pode ser que alguns acolhidos se sintam inibidos, inicialmente, de apresentar aspectos de suas vivências, o que pode ser amenizado com o tempo e a constância dos encontros, intercalandose com atendimentos individualizados, sendo esses realizados por uma dupla de profissionais.

O aspecto da relação entre o acolhido e o trabalhador do acolhimento institucional também aponta para outro limite institucional: as relações estabelecidas no âmbito do acolhimento nunca irão suprir a relação familiar que naquele momento está fragilizada ou ausente. Por mais que ainda se usem expressões como casa lar e mãe social, aquele espaço tem uma função bem definida: acolher o adolescente temporariamente para reinseri-lo na família e/ou comunidade. Pensando na relação institucional entre os profissionais e os acolhidos e a clareza dos papéis e formas de atuação de cada trabalhador, cada um poderá estar no contexto do acolhimento sem criar expectativas que nunca serão alcançadas: da parte do profissional, de que ele vai resolver as questões apresentadas pelo adolescente e atuar de forma assertiva e eficaz em seu processo de reintegração; da parte do acolhido, que vai ser atendido em todas as suas demandas, assim que solicitar, buscando uma atenção e um reconhecimento que não alcançou no contexto familiar. Mas vale ressaltar que, ao mesmo tempo, por mais que a atuação de cada profissional seja delimitada, ele não pode deixar de 
considerar que a postura clínica (Gaulejac \& Hanique, 2012), que favorece a escuta do adolescente, o reconhecimento do saber do acolhido e do seu sofrimento, é imprescindível para a construção de alternativas frente ao vivido pelo acolhido. Essa postura clínica pode se fazer presente tanto nos atendimentos dos psicólogos e assistentes sociais, quanto no trabalho de cuidadores sociais, educadores, administrativos, vigilantes e pessoal da limpeza e alimentação, que lidam com os adolescentes no cotidiano da instituição. Dessa forma, possibilita-se a construção de relações entre equipe e acolhidos, num nível em que cada um é reconhecido em suas habilidades e dificuldades, favorecendo que o comportamento muitas vezes agressivo ou apático de um acolhido não seja visto como algo rotineiro e banal e que mereça uma intervenção policial, no caso da agressão, ou ser ignorado, no caso da apatia, percebida como falta de interesse do adolescente. Assim, a partir da postura clínica, os profissionais podem apreender que esses comportamentos são, também, uma forma de comunicação e dizem do sofrimento do adolescente acolhido. É preciso, assim, proporcionar ao adolescente, por meio de um olhar atento e cuidadoso, que ele elabore um significado para seu comportamento, expresse o que sente com relação a ele e, com os profissionais, crie alternativas frente ao vivido.

Ainda sobre os comportamentos dos adolescentes, não basta que os profissionais simplesmente proíbam determinadas ações, que vão contra as regras da instituição. É preciso que busquem estratégias para compreenderem o significado de determinados comportamentos desses meninos e meninas, que eles buscam incessantemente, impedir, sem sucesso. Como exemplo, tem-se o caso de Simone. Os profissionais tentaram o tempo todo afastá-la das drogas, por meio da separação dela de grupos que faziam uso dessas substâncias, mas eles não tinham ciência de qual o significado e o lugar da droga na vida da adolescente. A maconha, como ela representou, fazia parte de sua rede de apoio. Então, tirar a maconha seria tirar um apoio importante na vida de Simone, ao que ela resistia fortemente. E reforçando o que 
indicou Parazelli (2002a), o comportamento concreto, o modo de utilização de um espaço, passa pelo modo de relação que uma pessoa possui com esse espaço, incluindo percepções e interpretações que vão sendo construídas ao longo do tempo. Como alternativa, é importante que se criem espaços transicionais, espaços esses que possibilitam certa reciprocidade e confiança nas relações entre os atores envolvidos, incluindo certa indeterminação nas regras estabelecidas, que favoreçam a construção de alternativas criativas frente às dificuldades encontradas. Não é sendo mais rígido quanto aos propósitos do acolhimento, quanto ao que está estabelecido enquanto norma de funcionamento da instituição, por meio do aumento do controle e da vigilância junto aos acolhidos, que vai se proporcionar que esse serviço alcance seus objetivos de reintegração familiar e/ou comunitária.

Como afirmou Simone, todos os adolescentes que ela conheceu na rua estavam acolhidos em uma instituição anteriormente, indicando que, de alguma maneira, a instituição não conseguiu protegê-los, o que seria seu papel principal. Rever seu modo de atuação e como a relação entre adolescentes e acolhidos se estabelece pode favorecer um olhar mais crítico de como essas instituições se organizam. Gaulejac (2007c) contribui nessa questão, pois segundo ele, as instituições que prestam serviços socioassistenciais, de forma geral, buscam atender demandas concretas dos sujeitos que dela necessitam, como alimentação e local para dormir, mas elas não se atentam ao fato de que esses sujeitos também possuem necessidade de criar, jogar, relacionar-se e descobrir coisas novas. Então, muitas respostas institucionais aparecem sob forma de matrículas em escola e cursos profissionalizantes, inserção no mercado de trabalho, quando não aparecem em termos de submissão dos usuários da instituição às normas e regras estabelecidas. A lógica institucional muitas vezes aparece de forma linear, atuando no comportamento dos adolescentes, no caso da instituições de acolhimento, buscando mudar esse comportamento com vistas a conduzi-lo à reinserção social, sem considerar aspectos subjetivo que se fazem presentes (Parazelli, 2002a) na relação entre acolhido e profissionais. 
Os profissionais se esforçam para mudar as reações dos acolhidos, mas não observam que, ao não provocarem certa alteração da percepção, da representação subjetiva que determinado assunto possui para o adolescente, não conseguem favorecer mudanças de comportamentos deles. Mas é necessário também que a percepção dos profissionais em relação ao adolescente acolhido seja avaliada e, talvez, ressignificada, pois se o adolescente é percebido como alguém que não aproveita as oportunidades que lhe são oferecidas, que não consegue se afastar de grupos que só o prejudica, como os que usam drogas ou se envolvem em exploração sexual, ou ainda, que não possui nenhuma habilidade que possa ser utilizada na construção de seu projeto de vida, existe uma tendência a desistir desse adolescente e focar suas ações na repressão de comportamentos inadequados.

Em relação ao uso de representação gráfica no momento da narrativa da própria história de vida pelos adolescentes participantes desta pesquisa, pode-se indicar alguns pontos positivos desse método. É possível que sentimentos que não são ditos de forma clara durante as narrativas dos adolescentes, apareçam nas representações gráficas elaboradas no decorrer da fala. No caso de Simone, ela escreveu a palavra "revolta" quando listava as drogas que havia conhecido antes e depois de ser acolhida institucionalmente, indicando que esse era um tipo de droga que havia conhecido após ser acolhida institucionalmente. E Marcos, ao se desenhar com o mundo em suas mãos, indica que, apesar de estar fora, excluído desse mundo, conseguia manipular, jogar com os que estão incluídos nesse contexto, para conseguir o que desejava. Isso pode ter ocorrido tanto na instituição de acolhimento, quando direcionava algumas situações a seu favor, por exemplo, fazendo acordos com funcionários para que o deixassem usar maconha no local, quanto por meio da venda de drogas, fazendo uso da dependência química de pessoas ditas incluídas para conseguir dinheiro e respeito dos pares.

Além do mais, Simone disse que era melhor desenhar do que falar, e Marcos pontuou que ele só havia conseguido contar sua história porque havia desenhado durante todo o momento 
de sua narrativa. Então, sugere-se que por meio do desenho, o adolescente pode melhor compreender sua história, seu vivido, apropriando-se dessa história e ressignificando-a ao identificar os elementos individuais e sociais que a atravessaram e a atravessam, as escolhas que fez e como foi criando alternativas face ao vivido. Essa experiência pode levar o adolescente acolhido a olhar com mais tranquilidade seu passado, olhar para o futuro no sentido de desejar ocupar um lugar, permitindo que sonhe com outras possibilidades de ser e estar no mundo. E ao invés de expressar angústia, raiva ou medo, por exemplo, na ação, por meio de atos violentos contra o outro e contra si mesmo, os adolescentes podem fazê-lo por meio dos desenhos.

Diante do exposto, tem-se que o trabalho com histórias de vida junto a adolescentes institucionalizados pode favorecer uma significação e ressignificação da trajetória de cada acolhido, que seus sentimentos podem ser reconhecidos, mas não de forma humilhante. Vale ressaltar que essas histórias não se referem somente a fatos ou acontecimentos, mas abarcam, principalmente, o vivido, com sentimentos e significados envolvidos para os acolhidos (Grell, 1986). Para o profissional acessar esse vivido e atuar sobre ele, pode-se intervir em dupla ou reunir um grupo de adolescentes, onde cada um pode contribuir para a ressignificação da história do outro. Talvez, dessa forma, a instituição pode alcançar aqueles adolescentes que se recusam a estarem fisicamente e subjetivamente implicados naquele contexto, por não desejarem se submeter ou assumir suas dificuldades, ou talvez não, mas esse é o limite do acolhimento institucional de adolescentes.

No trabalho com histórias de vida, pode-se também identificar modos de relação do acolhido com outros contextos, como família, escola, rua, hospital e até com a instituição onde está acolhido, trabalhando nessas interconexões. Dessa forma, sai-se do foco no adolescente para se trabalhar a relação dele com esses espaços, desculpabilizando-o de situações que sairem de seu controle. Por exemplo: ao invés de se trabalhar somente a 
importância da escola com um menino ou uma menina, trabalhar-se-ia como se dá a relação desse acolhido com o contexto escolar, onde se poderia identificar que, por exemplo, adolescentes que moram em instituições sofrem humilhações dos colegas de classe. Aí, nesse caso, essa relação seria trabalhada, favorecendo uma reaproximação do adolescente com a escola. Pode-se trabalhar também, a relação do acolhido com a instituição de acolhimento, para que se compreendam algumas questões que angustiam tanto equipe, quanto acolhidos, mas que não são nomeadas e ditas de forma clara. Pode-se perceber, por exemplo, que o uso do espaço do acolhimento pelo adolescente, somente para se alimentar, dormir e tomar banho, como se estivesse em um hotel, sendo que ele não participa de atividades ou da rotina da Unidade, não significa que esse acolhido não tenha vínculo com a instituição. Muito pelo contrário, pode significar que, apesar de passar longos momentos na rua, aquela instituição ainda consegue acolhê-lo e protegê-lo, como se fosse um porto seguro, uma referência de cuidado.

Retomando, então, a importância de uma postura clínica pelos profissionais da instituição de acolhimento, reconhecendo o sofrimento dos adolescentes e identificando as estratégias por eles utilizadas, não é tarefa simples, tendo em vista que trabalhar nesse contexto implica em reverberações, em ecos na subjetividade de cada membro da equipe. Confrontar-se com a vulnerabilidade, o sofrimento e a miséria de cada acolhido e sua família pode levar cada profissional a se questionar sobre suas próprias vulnerabilidades, provocando um mal estar que pode levar ao sentimento de vergonha ou culpa. Assim, sentimentos contraditórios influenciam comportamentos dos profissionais do Serviço de Acolhimento, que vão desde a compaixão para com o adolescente da instituição, à necessidade de se manter em distância afetivamente dessas histórias. Com isso, tem-se em muitos casos a dificuldade do trabalhador ouvir e levar em consideração a situação do adolescente. Nesse contexto, é de suma importância que os dirigentes dessas instituições se atentem para essas relações e 
ofereçam aos profissionais da equipe, espaços destinados a trabalhar essas questões, criando meios que favoreçam com que administrem e compreendam seu próprio sofrimento, advindo do trabalho com o acolhimento, analisando de quais formas esse sofrimento interferem na relação com os acolhidos (Gaulejac, 2007c). Afinal, quando se tem consciência dos limites e dos desafios no contexto do trabalho, ampliam-se as possibilidades de criação de alternativas. E como resumo das alternativas apontadas nesta pesquisa, do que pode ser efetivamente realizado em uma unidade de acolhimento, sugerem-se alguns modos de intervenção, indicando quais benefícios eles podem oferecer:

\section{Tabela 2}

Modos de Intervenção em Unidade de Acolhimento

\section{Modo de interevenção $\quad$ Benefícios}

Facilita expressão de sentimentos humilhantes e vergonhosos perante o grupo, pois o adolescente terá como apoio, outros adolescentes que poderão contar episódios semelhantes em suas histórias de vida, podendo ressignificá-los, ou seja, olhar para essas experiências de outra forma.

\section{Trabalho em grupo com}

Favorece que os profissionais acessem as percepções dos adolescentes adolescentes sobre o acolhimento, seu funcionamento e como as relações se estabelecem nesse contexto, no sentido de que tanto a equipe quanto os acolhidos possam compreender os comportamentos de todos os envolvidos, as ações e reações decorrentes dessas percepções. Assim, torna-se possível a criação de alternativas coletivas em relação aos comportamentos dos adolescentes considerados "difíceis" pela equipe, no sentido de 
co-responsabilizar todos os da instituição tanto pela presença, quanto pela resolução de dificuldades encontradas no cotidiano do acolhimento. Também evita-se a atuação dos profissionais que muitas vezes procuram modificar comportamentos dos adolescentes, ditos inapropriados (ex: uso de maconha dentro da instituição, faltas constantes à escola), sem procurar compreender qual o significado dessa ou aquela ação ou reação por parte do acolhido.

Proporciona que o foco saia dos problemas, das falhas e das dificuldades do adolescentes, pois pode-se trabalhar com aspectos positivos e habilidades que serão reconhecidas no grupo e pelo grupo.

O Plano Individual de Atendimento (PIA) pode ser feito de forma coletiva, de modo a favorecer o apoio afetivo dos colegas e a troca entre os adolescentes, na construção de possibilidades de futuro.

Favorece a compreensão, tanto dos profissionais quanto dos adolescentes, de como as relações se estabelecem (com escola, instituição de acolhimento, família entre outros grupos), o que auxilia na criação de alternativas rumo a relações mais respeitosas, saindo de uma lógica individualizada de responsabilização dos adolescentes pelos seus "fracassos".

Favorece a criação de alternativas coletivas frente às dificuldades encontradas no cotidiano do acolhimento. 
estimula a narrativa, a fala.

Facilita a expressão de elementos ou situações que não aparecem de forma clara na história de vida narrada.

Facilita a expressão de sentimentos não ditos.

Proporciona organização de ideias.

Torna a instituição de acolhimento mais atrativa, na medida em que ele terá a possibilidade de pertencer a outros grupos também e Ingresso em outros grupos não será reconhecido somente como alguém “do acolhimento". sociais (ex: grupos ligados ao Amplia a possibilidade de reconhecimento e de pertencimento, esporte e à música) que não seja somente o de estar acolhido em uma instituição. É o reconhecimento pela qualidade e não pela falha, seja sua ou de sua família.

\section{Revisão dos prontuários,}

incluindo a versão atualizada Proporciona que qualquer profissional que leia esse documento do adolescente sobre sua tenha ciência das mudanças em relação ao adolescente e de como história de vida e das esse passou a lidar com sua história de vida. ressignificações realizadas

Favorece a expressão e a consciência de sentimentos, significados, impressões, angústias e dificuldades dos trabalhadores.

Espaço de escuta coletivo entre membros da equipe

Favorece que elementos paradoxais e contraditórios do trabalho sejam ditos de forma explícitas, buscando-se o que é possível de ser feito na realidade na qual estão inseridos.

Favorece a construção coletiva de sentido para o trabalho e a 
criação de alternativas coletivas frente às situações vivenciadas, evitando-se o adoecimento individual.

Especificamente sobre o trabalho com histórias de vida (Gaulejac, 2014), ele é essencial, pois permite a apropriação da própria história pelo adolescente, ao identificar em qual medida sua história pessoal também é socialmente determinada, sendo atravessada por fatores psicológicos, sociais, históricos e culturais. E por meio desse trabalho, é possível sair da ilusão de um sujeito livre que pode, individualmente, resolver seus problemas, bem como renunciar à ilusão de que uma mudança na sociedade produzirá destinos menos problemáticos para as pessoas. Com isso, torna-se possível uma mudança na relação com o próprio passado, compreendendo-se os diversos fatores que agiram sobre cada adolescente e como eles contribuíram para que esse adolescente se posicionasse nas relações familiares e sociais. E mais, possibilita que se compreendam concretamente as várias formas de realidade possíveis e que o possível não se reduz ao provável. A partir dessa compreensão, dessa abertura de perspectivas, outras possibilidades podem ser criadas e planejadas para que se realize no futuro, podendo ser organizadas pelo adolescente no Plano de Atendimento Individual e Familiar (CONANDA \& CNAS, 2009), em colaboração com os profissionais da unidade de acolhimento.

Para o trabalho com histórias de vida, Gaulejac (2014) propõe a utilização de suportes metodológicos para que essas histórias emerjam, sejam percebidas e expressas. E esse trabalho pode ser feito em grupo, onde ocorre a análise coletiva do material produzido que, pouco a pouco o pessoal se dilui para uma problemática que faz sentido para o grupo. Então, como suportes, apresenta-se a seguir algumas alternativas, que podem ser utilizadas de forma individual ou grupal. A proposta é de que o trabalho seja realizado na sequência abaixo 
indicada, em dois ou três dias seguidos, mas que, no caso dos adolescentes, pode ser modificada para que cada intervenção ocorra em um dia, em um encontro.

Tabela 3

Trabalho com Histórias de Vida

$\begin{array}{lll}\text { Intervenção } & \text { Objetivo } & \text { Modo de utilização }\end{array}$

Em um papel grande, desenhar uma árvore genealógica contendo três ou quatro gerações.

Incluir para cada membro da família, Compreender questões nome, profissão, capital cultural (ex: relacionadas à dinâmica pai era músico, avó era artesã), local familiar e em qual medida o geográfico onde as pessoas viveram, destino individual está data de nascimento e de morte, condicionado pela história quando for o caso.

Árvore genealógica familiar e influenciado por mudanças econômicas, Incluir sinais particulares de cada políticas e sociais. Busca membro familiar, indicando com um acessar tradições, regras e sinal de positivo $(+)$ qualidades e hábitos familiares. Importante funções de prestígio assumidas, e com incentivar a busca pela origem sinal negativo (-), defeitos, da família. dificuldades e doenças que desenvolveu.

Apresentar ao grupo sua produção e, em seguida, ouvir dele suas impressões, questões e sentimentos suscitados.

Em uma grande folha, desenhar ou pintar (sem escrever nada) como os pais desejavam que ele fosse quando crescesse, o que desejavam que ele se tornasse.

Possibilita que o adolescente acesse $o$ que seus pais desejavam que ele se tornasse enquanto pessoa, seja real ou imaginário, e quais foram as repercussões desse projeto.
Apresentar para o grupo e deixar os participantes indicarem primeiro o que percebem, expressando emoções, sentimentos e interrogações.

Compartilhar a própria produção, incluindo aspectos afetivos, relacionais, ideológicos e sociais em relação ao desejo dos pais, além de se manifestar em relação aos apontamentos do grupo, expressando como se sentiu com as observações realizadas. 
Trajetórias de vida

Permite a identificação de momentos chave de inserção social, incluindo elementos que interviram e intervém em cada momento apresentado, explicitando a relação entre o adolescente $\mathrm{e}$ as situações identificadas. Possibilita também a análise da passagem entre a posição original e a posição social adquirida ao longo da própria trajetória.
Fazer a linha da vida, iniciando no momento do nascimento e terminando no momento atual desse trabalho.

Destacar momentos marcantes, que podem ser positivos ou não, localizando-os no tempo ao longo da linha da vida.

Apresentar sua linha da vida para o grupo, levando o adolescente a se questionar sobre as rupturas $\mathrm{e}$ as "escolhas" que fez ao longo do tempo.

Permitir ao grupo fazer observações e expressar sentimentos frente à história apresentada.

Os animadores do grupo podem escolher uma cena que sobressaiu durante o trabalho com as histórias de vida dos adolescentes, ou os próprios adolescentes, divididos em pequenos grupos, podem escolhar uma cena de uma história, para representá-la.

Os adolescentes, em pequenos Possibilita que os adolescentes grupos, representam a cena, representem o mal-estar experimentando situações sociais sentido, compartilhando-o e concretas.

tomando distância da situação. Permite também relativizar o que foi vivido, saindo da lógica de uma incapacidade individual, muitas vezes interiorizada ao longo da trajetória de vida.
Após representação, o grupo como um todo, faz observações sobre a cena, dizendo o que percebeu e sentiu enquanto telespectador, podendo questionar aspectos do que foi apresentado.

Em seguida, os adolescentes que representaram a cena, falam sobre sua experiência e como se sentiram nos papéis que representaram.

Também, ao final, algumas cenas podem ser refeitas com inversão de papéis entre os que a encenaram anteriormente, possibilitando maior conhecimento sobre as situações trabalhadas.

Por fim, enquanto limitações desta pesquisa, tem-se que ela abarcou especificamente histórias de vida de adolescentes com longo tempo de institucionalização e que tinham 
envolvimento com a rua, drogas e atos infracionais, não abrangendo histórias de vida de adolescentes que são acolhidos institucionalmente e que não têm essas vivências. $\mathrm{O}$ acesso ao vivido dos adolescentes se deu por meio de vários encontros com a pesquisadora, que ocorreram de forma intermitente, pois nem sempre os adolescentes estavam disponíveis ou dispostos a narrarem suas histórias durante os encontros. Outro ponto a ser considerado é a existência de algum tipo de vínculo anterior à pesquisa, entre a pesquisadora e os participantes que, se por um lado facilitou seu acesso às narrativas, pode ter direcionado a maneira de expressar a própria história, que ocorreu de forma individualizada, e a ênfase dada às situações pela pesquisadora.

Assim, seria interessante que outras pesquisas acessassem histórias de vida de adolescentes com outro tipo de perfil: que ficaram pouco tempo em acolhimento institucional (até dois anos, por exemplo), que frequentam a escola, que não usam qualquer tipo de substância psicoativa e que não estão envolvidos com ato infracional. Também, pesquisas que possam acessar histórias de vida de forma coletiva, o que pode facilitar a aproximação entre o participante e o pesquisador, no caso de vínculos não construídos anteriormente à pesquisa, além dos benefícios desse trabalho em grupo, seja reconhecimento coletivo do sofrimento, das dificuldades e das habilidades, seja na construção criativa de alternativas. E isso tudo, sempre na perspectiva de identificar aspectos do acolhimento institucional de adolescentes que podem ser reavaliados e reorganizados, na perspectiva de que a institucionalização seja menos prejudicial e mais protetiva para adolescentes vítimas de qualquer violação de direitos. 


\section{REFERÊNCIAS BIBLIOGRÁFICAS}

Abels-Eber, C. (2000). Analyse de contenu des récits. In C. Abels-Eber, Enfants placés et construction d'historicité (pp. 105-109). Éditions L’Harmattan/ Montreal, Canadá: L'Harmattan Inc.

Abels-Eber, C. (2000). Les fonctions de l'histoire de vie aves des enfants en perte de repères affectifs et spatio-temporels. In C. Abels-Eber, Enfants placés et construction d’historicité (pp. 69-75). Éditions L’Harmattan/ Montreal, Canadá: L’Harmattan Inc.

Amado, G. (2005). Implicação. In J. Barus-Michel, E. Enriquez, \& A. Lévy (Orgs.), Dicionário de Psicossociologia (pp. 281-286). Lisboa: Climepsi Editores.

Ariès, P. (1981). História social da criança e da família. Rio de Janeiro: LTC.

Arpini, D. M. (2003). Repensando a perspectiva institucional e a intervenção em abrigos para crianças e adolescentes. Psicologia: Ciência e Profissão, 21 (3), 70-75. Acessado em 06 de maio de 2014, de http://www.scielo.br/pdf/pcp/v23n1/v23n1a10.pdf

ABEP - Associação Brasileira de Empresas de Pesquisa (2014). Critério de Classificação Econômica Brasil: alteração na aplicação do Critério Brasil, válidas a partir de 01/01/2012. Acessado em 06 de maio de 2014, de http://www.abep.org/new/codigosCondutas.aspx

Aubert, N. (2012). La conquête de soi dans la société hypermoderne. In D. Desmarais, I. Fortier \& J. Rhéaume (Orgs.), Transformations de la modernité et pratiques (auto)biographiques (pp. 21-29). Quebéc: Presses de 1’Université du Québec.

Bellot, C. (2000). La trajectoire: un outil dans la compréhension de l'itinérance. In D. Laberge (Org.), L'errance urbaine (pp. 101-119). Quebec, Canadá: Éditions MultiMondes. 
Bertaux, D. (1976). Histoires de vies - ou récits de pratiques?, Méthodologie de l'approche biographique en Sociologie (Rapport final, Tome I). Paris: Centre d'Etude des Mouvements Sociaux.

Bertaux, D. (2009). Metodologia do Relato de Vida em Sociologia. In N. M. Takeuti \& C. Niewiadomski (Orgs), Reinvenções do Sujeito Social: Teorias e Práticas Biográficas. Porto Alegre: Sulina.

Blondel, F (2007). Les étapes de la désinsertion. In V.de Gaulejac \& I. T. Léonetti (Orgs.), La lutte des places (pp. 117-133). Paris: Desclée de Brower. (Trabalho original publicado em 1994).

Brasil (1988). Constituição da República Federativa do Brasil. Acessado em 30 de setembro de 2011, de

http://www.planalto.gov.br/ccivil_03/constituicao/constitui\%C3\%A7ao.htm

Brasil. (1990). Estatuto da Criança e do Adolescente: disposições constitucionais pertinentes: lei no 8.069, de 13 de julho de 1990. - 6. Ed. - Brasília: Senado Federal, Subsecretaria de Edições Técnicas.

Brasil. Secretaria Nacional de Assistência Social. Politica Nacional de Assistência Social. Brasília. (2004). Acessado em 30 de setembro de 2011, de http://www.mds.gov.br/secretarias/pnas_final.pdf

Brasil. Presidência da República/ Secretaria Especial dos Direitos Humanos/ Conselho Nacional dos Direitos da Criança e do Adolescente (2006). Plano Nacional de Promoção, Proteção e Defesa do Direito de Crianças e Adolescentes à Convivência Familiar e Comunitária. - Brasília-DF: Conanda.

Brasil. CONANDA/ CNAS (2009). Orientações Técnicas: Serviços de Acolhimento para Crianças e Adolescente: CONANDA/ CNAS. 
Brasil (2009). Lei Federal no 12.010 de 29 de julho de 2009 (2009, 3 de agosto). Dispõe sobre adoção; altera as Leis nos 8.069, de 13 de julho de 1990 - Estatuto da Criança e do Adolescente, 8.560, de 29 de dezembro de 1992; revoga dispositivos da Lei $\mathrm{n}^{\mathrm{o}}$ 10.406, de 10 de janeiro de 2002 - Código Civil, e da Consolidação das Leis do Trabalho - CLT, aprovada pelo Decreto-Lei $n^{\circ} 5.452$, de $1^{\circ}$ de maio de 1943 e dá outras providências. Acessado em 22 de agosto de 2011, de http://www.amperj.org.br/store/legislacao/leis/L12010.pdf

Brasília. SEDEST/ SUBPLAGI (2010). Censo da População em Situação de Rua do Distrito Federal. Brasília: SEDEST, SUBPLAGI.

Carreteiro, T. C. (1993). La dialectique sujet-groupe. In T. C. Carreteiro, Exclusion sociale et construction de l'identité (pp. 35-43). Paris: Éditons l'Harmattan.

Carreteiro, T. C. (1994). La quête de l'historicité. Cahiers de recherche sociologique, 22, 4957.

Carreteiro, T. \& Santos, P. F. (1999). La calle: espacios múltiples en Brasil. In Proposiciones Vol.34. Santiago do Chile: Edicões SUR. Acessado em 25 de setembro de 2012, de http://www.sitiosur.cl/r.php?id=782

Carreteiro, T. C (2002). Historia de una vida, historia de una sociedad de exclusión. Perfiles Latinoamericanos, 10(21). Faculdade Latinoamericana de Ciências Sociais: Distrito Federal, México, pp. 11-33.

Carreteiro, T. C (2003). Sofrimentos Sociais em Debate. Psicologia USP, 14(3). São Paulo: USP.

Carreteiro, T. C. (2009). Fazer de uma coletividade uma história coletiva. In N. M. Takeuti \& C. Niewiadomski (Orgs). Reinvenções do Sujeito Social: Teorias e Práticas Biográficas (pp. 126-140). Porto Alegre: Sulina. 
Carreteiro, T. C. (2012). Vidas fazendo história e construindo histórias de vida. In T. de C. Viana, G. S. Diniz, L. F. Costa, \& V. Zanello (Orgs.), Psicologia Clínica e Cultura Contemporânea (pp. 32-46). Brasília: Liber Livros. Acessado em 30 de junho de 2013, de $\quad$ http://www.ip.unb.br/images/M_images/psicologia-clinica-e-culturacontemporanea.pdf

Castel, R. (1994). La dynamique des processus de marginalisation: de la vulnérabilité à la désaffiliation. Cahiers de recherche sociologique, 22, 11-27.

Cedaro, J. J. \& Nascimento, J. P. G de (2014). Dor e gozo: relato de mulheres jovens sobre automutilações. São Paulo: Psicologia USP, 24(2), 203-223.

Coll, C., Marchesi, A \& Palacios, J. (2004). Desenvolvimento psicológico e educação: psicologia evolutiva (Vol. 1). Porto Alegre: Artmed.

Dinamarco, A. V. (2011). Análise exploratória sobre o sintoma da automutilação praticada com objetos cortantes el ou perfurantes, através de relatos expostos na Internet por um grupo brasileiro que se define como praticante de automutilação. Dissertação de Mestrado. Programa de Pós-Graduação em Psicologia, Instituto de Psicologia da Universidade de São Paulo, SP.

Drieu, D; Proia-Lelouey, N \& Zanello, F. (2011). Ataques ao corpo e traumatofilia na adolescência. Ágora, XIV(1), 9-20. Acessado em 20 de agosto de 2014, de http://www.scielo.br/scielo.php?pid=S1516-14982011000100001\&script=sci_arttext

Dujarier, M.-A. (2012a). Travail et organisation: quelques définitions. In Dujarier, M.-A., L'idéal au travail (pp. 49-62). Paris: Presses Universitaires de France.

Dujarier, M.-A. (2012b). Comment organiser un service de masse. In Dujarier, M.-A., L'idéal au travail (pp. 09-48). Paris: Presses Universitaires de France.

Dujarier, M.-A. (2012c). Norme d'ideal et perte d'idéal. In Dujarier, M.-A., L'idéal au travail (pp. 193-225). Paris: Presses Universitaires de France. 
Émond, M. (2007). Reconstruction de soi dans un récit de souffrance: Borderline de MarieSissi Labrèche. In L. Mercier \& J. Rhéaume (Orgs.), Récits de vie et sociologie clinique (pp. 61-83). Laval, Canadá: Les Presses de l’Université Laval.

Espindola, T \& Santos, R. da S (2003). Trabalhando com a história de vida: percalços de uma pesquisa(dora?). Revista da Escola de Enfermagem, 37(2). São Paulo: USP.

Espíndula, D. H. P., \& Santos, M. de F. de S. (2004). Representações sobre adolescentes a partir da ótica dos educadores sociais de adolescentes em conflito com a lei. Psicologia em Estudo, 9(3), 357 -367. Acessado em 17 de março de 2013, de http://www.scielo.br/pdf/pe/v9n3/v9n3a03.pdf

Fávero, E. T., Santana, A. B., Frias, C., Gueiros, D. A., Navas, E. P., Ganev, E., Ribeiro, E., Sette, M. B. A., Clemente, M. L., Pizza, M. T., Castanho, M. V. De B. C., Geacomini, M., Ribeiro, E. (2008). Famílias de crianças e adolescentes abrigados em São Paulo: uma aproximação a quem são, como vivem, o que pensam e o que desejam. In E. T. Fávero, M. A. F. Vitale \& M. V. Baptista (Orgs), Famílias de crianças e adolescentes abrigados (pp. 25-105). São Paulo: Paulus.

Ferrarotti, F. (1990a). Une méthodologie sociologique comme technique de l'écoute. In F. Ferrarotti, Histoire et histoires de vie (pp. 27-36). Paris: Méridiens Klincksieck.

Ferrarotti, F. (1990b). La biographie comme interaction. In F. Ferrarotti, Histoire et histoires de vie (pp. 49-59). Paris: Méridiens Klincksieck.

Ferrarotti, F. (1990c). La socialite de l'individuel. In F. Ferrarotti, Histoire et histoires de vie (pp. 61-68). Paris: Méridiens Klincksieck.

Ferreira, A. B. de H. (2010). Mini Aurélio: o dicionário da língua portuguesa. 8. ed. Curitiba: Positivo.

Flick, U. (2009). Introdução à Pesquisa Qualitativa. Porto Alegre: Artmed. 
Fortier, I. (2012). Le récit de vie, l'identité narrative et l'ethos public dans le contexte de la Nouvelle gestion publique et de la modernité radicale. In D. Desmarais, I. Fortier \& J. Rhéaume (Orgs.), Transformations de la modernité et pratiques (auto)biographiques (pp. 31-50). Quebéc: Presses de 1’Université du Québec.

Fukuda, C. C., Penso, M. A. \& Santos, B. R. (2013). Configurações sociofamiliares de crianças com múltiplos acolhimentos institucionais. Arquivos Brasileiros de Psicologia, 65(1), 70-87.

Gaulejac, V. de (2001a). Psicossociologia e sociologia clínica. In Araújo, J. N. G. de \& Carreteiro, T. C (Orgs), Cenários sociais e abordagem clínica. São Paulo: Escuta; Belo Horizonte: Fumec.

Gaulejac, V. de (2001b). Sociologues en quête d'identité. Cahiers internationaux de sociologia, 111(2), 355-362. Acessado em 17 de outubro de 2014, de http://www.cairn.info/revue-cahiers-internationaux-de-sociologie-2001-2-page-355.htm DOI: $10.3917 /$ cis. 111.0355

Gaulejac, V. de (2005a). Identidade. In J. Barus-Michel, E. Enriquez, \& A. Lévy (Orgs.), Dicionário de Psicossociologia (pp. 104-109) Lisboa: Climepsi Ed.

Gaulejac, V. De (2005b). Opciones metodológicas. In V. de Gaulejac, S. R. Marquez \& E. T. Ruiz (Orgs.), Historia de vida: psicoanálisis y sociología clínica (pp. 49-60). México: Edición de la Universidad Autónoma de Querétaro.

Gaulejac, V. De (2005c). Historia e historicidad. In V. de Gaulejac, S. R. Marquez \& E. T. Ruiz (Orgs.), Historia de vida: psicoanálisis y sociología clínica (pp. 61-90). México: Edición de la Universidad Autónoma de Querétaro.

Gaulejac, V. de (2006a). A identidade ferida. Em As origens da vergonha. São Paulo: Via Lettera Editora e Livraria. (Trabalho original publicado em 1987). 
Gaulejac, V. de (2006b). As violências extremas. Em As origens da vergonha. São Paulo: Via Lettera Editora e Livraria. (Trabalho original publicado em 1987).

Gaulejac, V. de (2006c). Os patamares da vergonha. Em As origens da vergonha. São Paulo: Via Lettera Editora e Livraria. (Trabalho original publicado em 1987).

Gaulejac, V. de (2006d). A vergonha diante da vergonha. Em As origens da vergonha. São Paulo: Via Lettera Editora e Livraria. (Trabalho original publicado em 1987).

Gaulejac, V. de (2006e). Vergonha e contratransferência. Em As origens da vergonha. São Paulo: Via Lettera Editora e Livraria. (Trabalho original publicado em 1987).

Gaulejac, V. de (2006f). Eu precisava falar disso. Em As origens da vergonha. São Paulo: Via Lettera Editora e Livraria. (Trabalho original publicado em 1987).

Gaulejac, V. de (2006g). A ambição, um contraveneno. Em As origens da vergonha. São Paulo: Via Lettera Editora e Livraria. (Trabalho original publicado em 1987).

Gaulejac, V. de (2006h). Tenho vergonha, mas tenho fome. Em As origens da vergonha. São Paulo: Via Lettera Editora e Livraria. (Trabalho original publicado em 1987).

Gaulejac, V. de (2006i). As reações defensivas. Em As origens da vergonha. São Paulo: Via Lettera Editora e Livraria. (Trabalho original publicado em 1987).

Gaulejac, V. de (2006j). A vergonha gruda na pele. Em As origens da vergonha. São Paulo: Via Lettera Editora e Livraria. (Trabalho original publicado em 1987).

Gaulejac, V. de (2006k). Libertar-se da vergonha. Em As origens da vergonha. São Paulo: Via Lettera Editora e Livraria. (Trabalho original publicado em 1987).

Gaulejac, V. de (20061). Ser ajudado é humilhante. Em As origens da vergonha. São Paulo: Via Lettera Editora e Livraria. (Trabalho original publicado em 1987).

Gaulejac, V. de (2006m). A queda da criança-rei. Em As origens da vergonha. São Paulo: Via Lettera Editora e Livraria. (Trabalho original publicado em 1987). 
Gaulejac, V. de (2006n). Pobreza é vergonha!. Em As origens da vergonha. São Paulo: Via Lettera Editora e Livraria. (Trabalho original publicado em 1987).

Gaulejac, V. de (2007a). Le manager et le RMIste. In V.de Gaulejac \& I. T. Léonetti (Orgs.), La lutte des places (pp. 29-38). Paris: Desclée de Brower. (Trabalho original publicado em 1994).

Gaulejac, V. de (2007b). De l'excellence à l'exclusion. In V.de Gaulejac \& I. T. Léonetti (Orgs.), La lutte des places (pp. 39-49). Paris: Desclée de Brower. (Trabalho original publicado em 1994).

Gaulejac, V. de (2007c). Le contre-transfert institutionnel. In V.de Gaulejac \& I. T. Léonetti (Orgs.), La lutte des places (pp. 257-273). Paris: Desclée de Brower. (Trabalho original publicado em 1994).

Gaulejac, V. de (2007d). Le rapport aux institutions. In V.de Gaulejac \& I. T. Léonetti (Orgs.), La lutte des places (pp. 241-255). Paris: Desclée de Brower. (Trabalho original publicado em 1994).

Gaulejac, V. de (2007e). Demandes existentielles, réponses institutionnelles. In V.de Gaulejac \& I. T. Léonetti (Orgs.), La lutte des places (pp. 231-239). Paris: Desclée de Brower. (Trabalho original publicado em 1994).

Gaulejac, V. de (2009). O sujeito face à sua história: a démarche "romance familiar e trajetória social”. In N. M. Takeuti, \& C. Niewiadomski (Orgs.), Reinvenções do Sujeito Social: Teorias e Práticas Biográficas (pp. 61-73). Porto Alegre: Sulina.

Gaulejac, V. de (2014). Opções e suportes metodológicos. In V. de Gaulejac, A neurose de classe: trajetória social e conflitos de identidade (pp. 167-181). São Paulo: Via Lettera. (Trabalho original publicado em 1987). 
Guareschi, P. A. (2010). Pressupostos psicossociais da exclusão: competitividade e culpabilização. In B. Sawaia (Org.), As artimanhas da exclusão: análise psicossocial e ética da desigualdade social (pp. 143-157). 10ª ed. Petrópolis, RJ: Vozes.

Hurtubise, R. \& Vatz-Laaroussi, M. (2000). Jeunes dans/ de la rue et stratégies de réseaux. In D. Laberge (Org.), L'errance urbaine (pp. 179-191). Quebec, Canadá: Éditions MultiMondes.

Laberge, R. \& Roy, S. (1994). Interroger l'itinérance: stratégies et débats de recherche. Cahiers de recherche sociologique, 22, 11-27.

Le Grand, J-L (2005). Histórias de Vida. In Barus-Michel, J; Enriquez, E \& Lévy, A. (Orgs). Dicionário de Psicossociologia. Lisboa, Portugal: Climepsi Editores.

Legrand, M. (1993). Le récit de vie. In M. Legrand, L'approche biographique (pp. 178-241). França: Éditions Desclée de Brouwer.

Léonetti, I. T. (2007a). Intégration et exclusion. In V.de Gaulejac \& I. T. Léonetti (Orgs.), La lutte des places (pp. 51-78). Paris: Desclée de Brower. (Trabalho original publicado em 1994).

Léonetti, I. T. (2007b). La prodution sociale de la désinsertion. In V.de Gaulejac \& I. T. Léonetti (Orgs.), La lutte des places (pp. 79-99). Paris: Desclée de Brower. (Trabalho original publicado em 1994).

Léonetti, I. T. (2007c). Les responses individuelles. In V.de Gaulejac \& I. T. Léonetti (Orgs.), La lutte des places (pp. 181-187). Paris: Desclée de Brower.

Léonetti, I. T. (2007d). Contraintes sociales et stratégies individuelles: la place de l'acteur. In V.de Gaulejac \& I. T. Léonetti (Orgs.), La lutte des places (pp. 219-227). Paris: Desclée de Brower. (Trabalho original publicado em 1994).

Levy, A (2001). Ciências Clínicas e Organizações Sociais. Belo Horizonte: Autêntica/ FUMEC. 
Lussier, V. \& Poirier, M. (2000). Parcours de rupture ou quête de reconnaissance et d'identité? L’impact des représentations parentales sur l'itinéraire de jeunes itinérants et itinérantes de Montréal. In D. Laberge (Org.), L'errance urbaine (pp. 161-178). Quebec, Canadá: Éditions MultiMondes.

Marques, C. de C. \& Czermak, R. (2008). O olhar da psicologia no abrigo: uma cartografia. Psicologia \& Sociedade, 20(3), 360-366. Acessado em 12 de março de 2012, de http://www.scielo.br/pdf/psoc/v20n3/06.pdf

Marques, W. E. U (2010). Rua, virilidade e violência: crianças e jovens em situação de extrema vulnerabilidade social e pessoal. In N. A. de Morais; L. Neiva-Silva \& S. H. Koller (Orgs), Endereço desconhecido: crianças e adolescentes em situação de rua (pp. 381-402). São Paulo: Casa do Psicólogo.

Martins, H. H. T. de Souza (2004). Metodologia qualitativa de pesquisa. Educação e Pesquisa, 30(3). São Paulo.

Massa, A. de S. C. (2010). Le mouvement Hip Hop: un pont reliant les jeunes des banlieues et ceux des favelas. Revista Interdisciplinar de Trabalhos sobre a América, 04. Acessado em 28 de junho de 2014, de www.revue-rita.com/regards-56/le-mouvement-hip-hop-.html

Mussen, P. H., Conger, J. J., Kagan, J. \& Huston, A. C. (2001). Desenvolvimento e personalidade da criança. São Paulo: Harbra.

Paulilo, M. A. S (1999). A Pesquisa Qualitativa e a História de Vida. Serviço Social em Revista, 2(2). Londrina, Paraná.

Parazelli, M. (2002a). Une hypothèse géosociale de la socialisation marginalisée. In M. Parazelli, La rua attractive (pp. 127-178). Quebec, Canadá: Presses de l’Université du Québec.

Parazelli, M. (2002b). Domination, superficialité et détachement. In M. Parazelli, La rua attractive (pp. 223-278). Quebec, Canadá: Presses de l’Université du Québec. 
Parazelli, M. (2002c). Dépendance et Indépendance. In M. Parazelli, La rua attractive (pp. 205-222). Quebec, Canadá: Presses de l’Université du Québec.

Parazelli, M. (2000). L'appropriation de l'espace et les jeunes de la rue: un enjeu identitaire. In D. Laberge (Org.), L'errance urbaine (pp. 193-220). Quebec, Canadá: Éditions MultiMondes.

Pereira, S. E. F. N. (2009). Redes sociais de adolescentes em contexto de vulnerabilidade social e sua relação com os riscos de envolvimento com o tráfico de drogas. Tese de Doutorado. Departamento de Psicologia Clínica, Instituto de Psicologia, Universidade de Brasília, Brasília. Acessado em 10 de julho de 2013, de http://hdl.handle.net/10482/4416 Rhéaume, J. \& Roy, S. (2000). Definig without discriminating? Ethnicity and social problems: the case of street youth in Canada. In C. Truman; D. M. Mertens \& B. Humphries (Orgs.), Research and inequality (pp. 236-247). Inglaterra: University College London Press.

Rhéaume, J. (2007). Au coeur de la sociologie clinique: sujet charnel, lien social et acteurs sociaux. In L. Mercier \& J. Rhéaume (Orgs.), Récits de vie et sociologie clinique (pp. 6183). Laval, Canadá: Les Presses de l’Université Laval.

Rhéaume, J. (2009). Relato de vida coletivo e empoderamento. In N. M. Takeuti, \& C. Niewiadomski (Orgs.), Reinvenções do Sujeito Social: Teorias e Práticas Biográficas (pp. 166-188). Porto Alegre: Sulina.

Rossetti-Ferreira, M., Almeida, I. G. de, Costa, N. R. do A., Guimarães, L. de A., Mariano, F. N., Teixeira, S. C. de P., Serrano, S. A. (2012). Acolhimento de crianças e adolescentes em situações de abandono, violência e rupturas. Psicologia: Ciência e Crítica, 25 (2), 390-399. Acessado em 15 de outubro de 2011, de http://www.scielo.br/pdf/prc/v25n2/a21v25n2.pdf 
Roy, S.; Rhéaume, J.; Rozier, M. \& Hétu, P. (2000). L’hébergement des jeunes mineurs en difficulté: une solution? In D. Laberge (Org.), L'errance urbaine (pp. 405-416). Quebec, Canadá: Éditions MultiMondes.

Ruiz, E. T. (2013a). El niño en situación de calle y sy família. In E. T. Ruiz (Org.), Un enfoque socioclínico del fenómeno de la vida en la calle (pp. 73-90). México, Universidad Nacional Autónoma de México: Juan Pablos Editor.

Ruiz, E. T. (2013b). Consideraciones teórico-metodológicas en el trabajo con jóvenes en proceso de callejerización. In E. T. Ruiz (Org.), Un enfoque socioclínico del fenómeno de la vida en la calle (pp. 121-149). México, Universidad Nacional Autónoma de México: Juan Pablos Editor.

Sawaia, B. (2010). Introdução: exclusão ou inclusão perversa? In B. Sawaia (Org.), As artimanhas da exclusão: análise psicossocial e ética da desigualdade social (pp. 07-13). $10^{\mathrm{a}}$ ed. Petrópolis, RJ: Vozes.

Sévigny, R. (2001). Abordagem clínica nas ciências humanas. In J. N. G. de Araújo \& T. C. Carreteiro (Orgs.), Cenários sociais e abordagem clínica (pp. 15-33). São Paulo: Escuta; Belo Horizonte, Fumec.

Silva, A. C. C. S. da, \& Adan, L. F. L (2003). Crescimento em meninos e meninas com puberdade precoce. Arquivos Brasileiros de Endocrinologia e Metabologia, 47(4), 422431.

Siqueira, A. C. (2006). Instituições de Abrigo, Família e Redes de Apoio Social e Afetivo em Transições Ecológicas na Adolescência. Dissertação de Mestrado. Instituto de Psicologia, Universidade Federal do Rio Grande do Sul, Porto Alegre, RS.

Takeuti, N. M. (2009). Desafios da abordagem socioclínica e biográfica no contexto sociocultural e político brasileiro. In N. M. Takeuti, \& C. Niewiadomski (Orgs.), 
Reinvenções do Sujeito Social: Teorias e Práticas Biográficas (pp. 74-94). Porto Alegre: Sulina. 


\section{Apêndice A - Termo de Consentimento Livre e Esclarecido}

Você está sendo convidado(a) a participar da pesquisa Crianças e adolescentes em acolhimento institucional no Distrito Federal: estudo das condições familiares, institucionais e sociais, coordenada pela Profa. Dra. Maria Aparecida Penso, com financiamento do CNPQ e da Universidade Católica de Brasília. Seu objetivo é: conhecer as condições familiares, institucionais e sociais das crianças e adolescentes constantes dos processos de acolhimento institucional em andamento na Promotoria de Justiça de Defesa da Infância e da Juventude no período de janeiro de 2007 a agosto de 2009, analisados na pesquisa realizada em uma parceria entre Escola Superior do Ministério Público do Distrito Federal e Territórios, Promotoria de Defesa da Infância e Juventude do Distrito Federal e Universidade Católica de Brasília que foram acolhidas institucionalmente mais de uma vez, visando contribuir para o conhecimento desta realidade e para a discussão de novos procedimentos que possibilitem uma melhor garantia do seu direito à convivência familiar e comunitária, evitando a reincidência do acolhimento.

A sua participação é voluntária e será documentada através deste Termo de Consentimento Livre e Esclarecido que será lido pelos pesquisadores e posteriormente, assinado ou identificado por impressão dactiloscópica. Você será entrevistado(a) em um ou dois encontros. Estes encontros serão gravados para que seja possível realizar o estudo do que vocês disserem

Os resultados da pesquisa serão divulgados em artigos, capítulos de livros e encontros científicos no Brasil e no exterior.

Caso você concorde em participar do estudo, seu nome e identidade serão mantidos em rigoroso sigilo. Somente os pesquisadores terão acesso a suas informações para verificar os dados do estudo. Você receberá uma via assinada deste termo e a outra via ficará com o pesquisador.

As dúvidas e questões que surgirem em relação ao estudo, poderão ser tiradas com os pesquisadores durante os encontros. Para tirar dúvidas sobre os seus direitos como participantes no estudo, você pode entrar em contato com o Comitê de Ética em Pesquisa da Universidade Católica de Brasília através do telefone (61) 3356-9784.

Sua participação no estudo é voluntária e você pode escolher não fazer parte dele ou desistir a qualquer momento. Em caso de desistência você deverá entrar em contato com a coordenadora da pesquisa, Maria Aparecida Penso no telefone 9967-9977. 
Ressaltamos que esse estudo não apresenta risco para a sua vida. Os encontros ocorrerão em um local em que a privacidade e segurança estão presentes. Os pesquisadores se colocam disponíveis para ajudar em caso de necessidade de ajuda psicológica por consequência das entrevistas. Para isto você deverá avisar os pesquisadores para que possa ser agendado um horário.

EU

Identidade $\mathrm{n}^{\mathrm{o}}$

SSP -

declaro que fui informado e devidamente esclarecido do projeto de pesquisa intitulado "Crianças e adolescentes em acolhimento institucional no Distrito Federal: estudo das condições familiares, institucionais e sociais, quanto aos itens da resolução 196/96. Declaro, que após ser esclarecido pelo pesquisador a respeito da pesquisa, consinto voluntariamente em participar desta pesquisa.

Brasília. de. $.20 \ldots$

Nome:

RG: Data de nascimento Sexo $\mathrm{M}(\mathbf{~}) \mathrm{F}(\mathrm{)}$

Endereço:

Bairro: Cidade: CEP: ...Tel:

Responsável:

RG: Data de nascimento: ..Sexo M( ) F( ) 


\section{Apêndice B - Parecer Consubstanciado de Projeto de Pesquisa}

Título do Projeto: Crianças e adolescentes abrigados no Distrito Federal: estudo das condições familiares, institucionais e sociais.

Pesquisador Responsável: Maria Aparecida Penso

Data da versão: $31 / 03 / 2010$ Cadastro : 056/2010 Data do Parecer : 19/04/2010

Grupo e Área Temática: III - Projeto fora das áreas temáticas especiais

\section{Objetivos do Projeto}

Objetivo Geral : Conhecer as condições familiares, institucionais e sociais das crianças e adolescentes constantes dos processos de acolhimento institucional em andamento na Promotoria de Justiça de Defesa da Infância e da Juventude, visando contribuir para a sistematização de novos procedimentos que possibilitem uma melhor garantia do direito à convivência familiar e comunitária dessas crianças e adolescentes.

\section{Objetivos Específicos :}

- Conhecer a estrutura familiar no que diz respeito às pessoas que fazem parte da família quanto ao sexo, idade, grau de escolaridade, profissão, grau de parentesco;

- Identificar os responsáveis pela criança/adolescente;

- Conhecer as condições sócio-econômicas da família quanto à renda familiar e condições de moradia;

- Conhecer as condições da criança/adolescente e de sua família que determinaram o acolhimento institucional;

- Identificar o tempo de acolhimento institucional da criança/adolescente e as providências após a saída das crianças/adolescentes do abrigo;

- Conhecer as condições atuais da família e possíveis mudanças que aconteceram após o acolhimento institucional dos filhos;

- Conhecer a atuação dos diferentes atores envolvidos no processo de acolhimento institucional: dirigentes de abrigos, conselheiros tutelares, promotores de justiça e outros que serão identificados no processo de cada criança/adolescente;

- Conhecer as condições físicas e de cuidados recebidos pelas crianças e adolescentes nas instituições de abrigamento onde as mesmas vivem.

\section{Sumário do Projeto}

O projeto visa a sistematização de novos procedimentos que possibilitem garantir o direito à convivência de crianças e adolescentes em situação de abrigamento. Os processos de acolhimento institucional em andamento na promotoria de Justiça de Defesa da Infância e da Juventude serão analisados para se obter conhecimento sobre a situação sócio-econômica das famílias que possuem crianças abrigadas. Serão realizadas entrevistas com os profissionais da Promotoria de Justiça de Defesa da Infância e da Juventude/ MPDFT, Conselho Tutelar ou Abrigo, abordando questões sobre o processo de abrigamento e acompanhamento das crianças e adolescentes acolhidos institucionalmente. Três famílias que possuem crianças abrigadas serão convidadas a participar da pesquisa, para que se aprofunde no conhecimento da sua realidade, permitindo, com isso, a produção de procedimentos que garantam os direitos das crianças e adolescentes à convivência familiar e comunitária.

\begin{tabular}{|l|l|}
\hline \multicolumn{1}{|c|}{ Itens Metodológicos e Éticos } & \multicolumn{1}{c|}{ Situação } \\
\hline Título & Adequado \\
\hline Autores & Adequados \\
\hline Local de Origem na Instituição & Adequado \\
\hline Projeto elaborado por patrocinador & Não \\
\hline Aprovação no país de origem & Não necessita \\
\hline
\end{tabular}




\begin{tabular}{|l|l|}
\hline Local de Realização & Outros (citar no comentário) \\
\hline Outras instituições envolvidas & Sim \\
\hline Condições para realização & Adequados \\
\hline
\end{tabular}

Comentários sobre os itens de identificação : A pesquisa será realizada em parceria com a Promotoria de Justiça de Defesa da Infância e da Juventude/MPDFT e será realizada na Promotoria.

\begin{tabular}{|l|l|}
\hline Introdução & Adequada \\
\hline
\end{tabular}

Comentários sobre a Introdução : A introdução identifica o projeto: atende à chamada do edital da Pro-Reitoria de Pós-Graduação e Pesquisa da UCB, na linha temática "Desenvolvimento de técnicas e metodologias transformadas que representem soluções para inclusão social e melhoria das condições de vida: que contribuam para a redução da pobreza, das desigualdades sociais e para o desenvolvimento sustentável e solidário". Identifica-o também como prosseguimento ao projeto anterior realizado pela UCB em parceria com a Escola Superior do Ministério Público e a Promotoria de Justiça de Defesa da Infância e da Juventude, que analisou 545 processos de abrigamento. O presente projeto pretende conhecer as condições familiares e sociais das crianças e adolescentes abrigados.

\begin{tabular}{|c|c|}
\hline Objetivos & Adequados \\
\hline \multicolumn{2}{|l|}{ Comentários sobre os Objetivos } \\
\hline \multicolumn{2}{|l|}{ Pacientes e Métodos } \\
\hline Delineamento & Adequado \\
\hline Tamanho de amostra & Total 3 Local \\
\hline Cálculo do tamanho da amostra & Não informado \\
\hline Participantes pertencentes a grupos especiais & Não \\
\hline Seleção equitativa dos indivíduos participantes & Não se aplica \\
\hline Critérios de inclusão e exclusão & Adequados \\
\hline Relação risco-benefício & Adequada \\
\hline Uso de placebo & Não utiliza \\
\hline Período de suspensão de uso de drogas (wash out) & Não utiliza \\
\hline Monitoramento da segurança e dados & Não se aplica \\
\hline Avaliação dos dados & Adequada - qualitativa \\
\hline Privacidade e confidencialidade & Adequada \\
\hline Termo de Consentimento & Adequado \\
\hline Adequação às Normas e Diretrizes & Sim \\
\hline
\end{tabular}

Comentários sobre os itens de Pacientes e Métodos: Quanto ao tamanho da amostra, consta que serão entrevistadas 3 famílias. Não consta o número de profissionais da Promotoria que serão entrevistados.

\begin{tabular}{|l|l|}
\hline Cronograma & Adequado \\
\hline Data de início prevista & Agosto de 2010 \\
\hline Data de término & Junho de 2012 \\
\hline Orçamento & Adequado \\
\hline Fonte de financiamento externa & Não \\
\hline
\end{tabular}

Comentários sobre o Cronograma e o Orçamento

Referências Bibliográficas

Comentários sobre as Referências Bibliográficas

Recomendação : APROVAR

Comentários gerais sobre o Projeto : O projeto atende às exigências da Resolução 196/96 e recomenda-se sua aprovação pelo Comitê de Ética em Pesquisa. O projeto foi aprovado na reunião de 19/04/10 do CEP-UCB. Após um ano da realização da pesquisa é compromisso dos/das proponentes a entrega de relatório final ou versão final do trabalho. 


\section{Apêndice C - Roteiro de entrevista sobre trajetória profissional}

1. Conte sobre sua formação profissional;

2. Apresente sua trajetória profissional, incluindo estágios e empregos aos quais teve acesso. Quais são os pontos importantes dessa trajetória?

3. Sobre seu local de trabalho atual:

a. Descreva-o;

b. Apresente seu trabalho, as atividades que você realiza. Qual é seu objetivo principal?

c. Quais são os pontos positivos e negativos desse trabalho?

d. Para você, o que é mais fácil e o que é mais difícil nesse local?

e. Apresente, de forma geral, os acolhidos que estão no local atualmente;

f. Quais são as maiores dificuldades que eles vivem?

g. Quais são as habilidades que eles possuem? trabalho deles?

h. Descreva sua equipe de trabalho. Em linhas gerais, como você percebe o

i. Nesse local de trabalho, quais mudanças você gostaria de ver?

j. Como você se vê nesse local de trabalho? Como se sente trabalhando lá?

k. Em relação a situações concretas, qual o caso que você acompanhou e obteve os resultados esperados por você? E em qual caso você não chegou aos objetivos desejados por você? Como se sentiu nessas situações?

1. O que você conhece da situação em que alguns adolescentes que estão em abrigo evadem para a rua e voltam tempos depois para o acolhimento institucional? Na sua percepção, como isso é visto por outros profissionais da instituição?

m. Nessa pesquisa também participam dois adolescentes, aos quais você conheceu. Descreva a dinâmica deles no abrigo. Quais foram os pontos marcantes? Na sua percepção, quais as facilidades e as dificuldades da equipe profissional em relação a eles?

4. Você tem algo a acrescentar? 